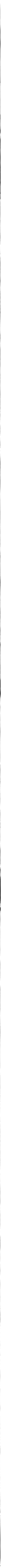


4. दो

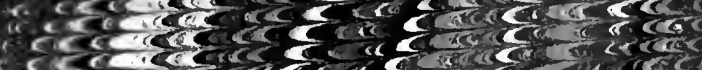

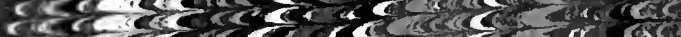

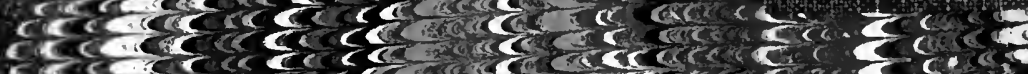

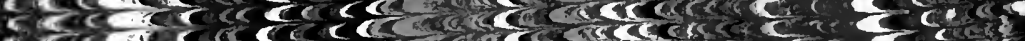

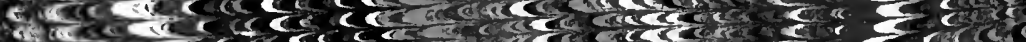

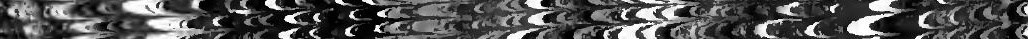
c.

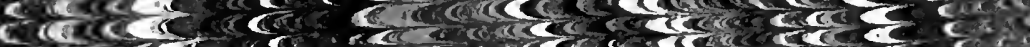

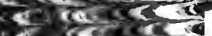

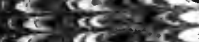

$\operatorname{cec} \csc 25$

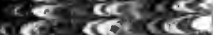

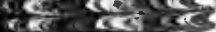

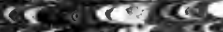

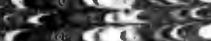

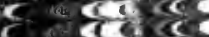

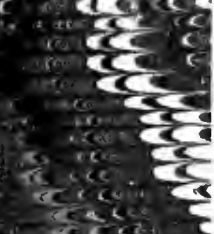

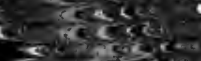

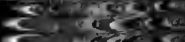

$E \rightarrow \mathrm{e}^{2}$

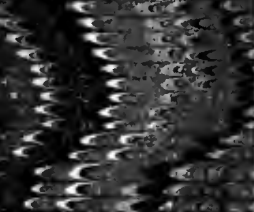

THE LIBRARY

OF

THE UNIVERSITY

OF CALIFORNIA

LOS ANGELES

GIFT OF

FREDERIC THOMAS BLANCHARD

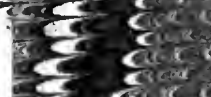

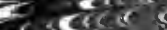
$\rightarrow$ coscos. c. cost as $-\frac{\operatorname{coc} c o s}{2}$ icectivin

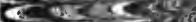
बह दरe दो

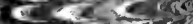

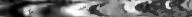
carac us act?

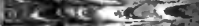
W<cota क क सcrence

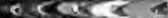
Es esest $\Leftrightarrow 2 \csc x$

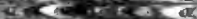

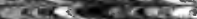
xes $\operatorname{con} 2 \mathrm{x}$

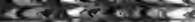
ce cons ocas cस $200 \times 2+\infty$ carererenty $\cos 0 x+25$

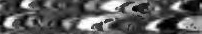
mere Cह arcerec $\operatorname{coccc} x=$ motes $=2$ mexir $x$

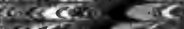
ceca 4 ac crescen $\Rightarrow$ cect as: is

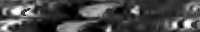

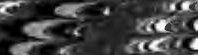
acied

Fincercese acereste कर रेखे

C.

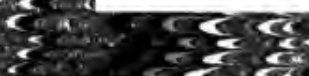

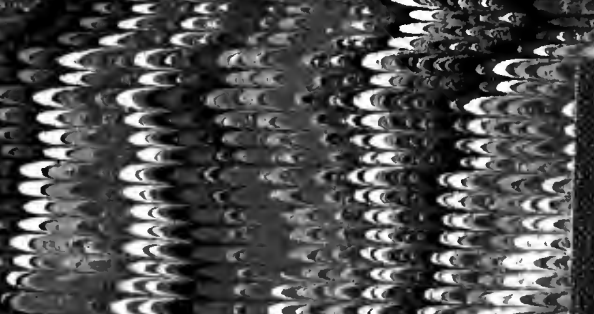

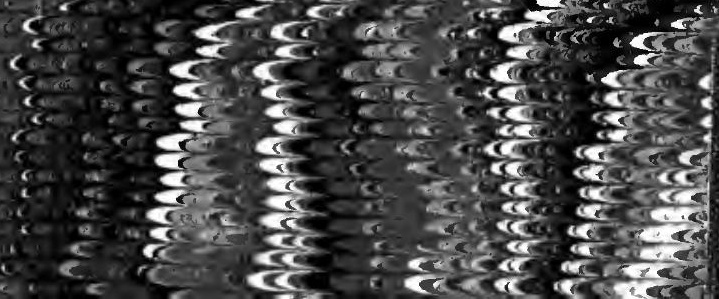


Edward Buchanan, with the best wishes of his sincere friend, other Intwisle.

on his leaving Eton, Christmas, $186 \%$ 


\section{Digitized by the Internet Archive in 2007 with funding from Microsoft Corporation}




\section{LIFE AND THEATRICAL TIMES}

OF

\section{CHARLES KEAN, F.S.A.}

INCLUDING A SEMMARY OF

THE ENGLISH STAGE FOR THE LAST FIFTY YEARS,

AND A DETAILED ACCOUXT OF THE

MANAGEMENT OF THE PRINCESS'S THEATRE, FROM 1850 TO 1859 .

\section{BY JOHN WILLIAM COLE.}

"Orator ad vos venio ornatu prologi :

Sinite exorator ut sim.-

Quia sciebam dubiam fortunam esse scenicam,

Spe incerta certum mihi laborem sustuli."-Terestir Hecrra.

"There's nothing simply good nor ill alone;

of every quality, comparison

The only measure is, and judge opinion."-DR. Donse's Poess.

IN TWO VOLUMES.

VOL. II.

\section{LONDON :}

RICHARD BENTLEY, NEW BURLINGTON STREET,

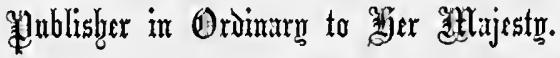

1859. 



\section{College \\ Library}

\section{CONTENTS TO VOL. II.}

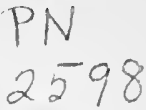

\section{CHAPTER I.}

Charles Kean enters on the Management of the Princess's Theatre in Partnership with Mr. Keeley - "Twelfth Night" the Opening Play-The Great Exhibition of 1851-Its Success and Objeets-London Inundated with Foreigners-Opinion of the French on English Character and Habits-Distinction between French and English Dramatists-The Theatres Crowded nightly throughout the Summer-Company engaged at the Princess's Theatre-Old Pieces revived-New Pieces produced-The "Gamester" on Mr. and Mrs. C. Kean's Benefit Night-Remarks on the Moral Tendency of the Play and the Lesson it Inculcates-Conclusion of the Seasun-Its great Success-Retirement of Mr. Macready-His Farewell Benefit and Parting Address at Drury Lane-Short Summary of his Career-The Conspiracy against him in America .

\section{CHAPTER II.}

The Princess's Theatre under the sole Management of Mr. Charles Kean-The Season eommences with the "MIerry Wives of Windsor"-Cast of the Comedy-Critical Observations-"King John," the first great Historical Revival-Mrs. Siddons' Reflections on the Character of Constance-The "Corsican Brothers" - Many Versions and Burlesques of the latter-Its great A ttractions at the Princess's-Supernatural Agency-Well-authenticated Ghost Stories-Mademoiselle Clairon's Disembodied Persecutor-Tender Precautions-Our Clerks-The Easter Spectar cle, "Wittikind and his Brothers"-Mr. Lovell's Play of the "Trial of Love"-The Phantasm of the Vampire-The Pantomime of "Betty Taylor"-Close of the Scason on the 14th of July-Number of Pieces performed-General Result . ' .

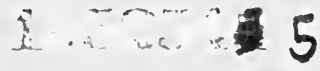


CHAPTER III.

Mr. C. Kean's third Season at the Princess's-The Prima Donna -Melodrama of "Mont St. Michel"-Engagement and First Appearance of Mr. Wright-Mr. Westland Marston's Play of "Anne Blake"-Retirement of Mr. Bartley-Pantomime of "Cherry and Fair Star"-Mr. Douglas Jerrold's Comedy of "St. Cupid, or Dorothy's Fortune "-Revival of "Macbeth""Fly Leaf"-General Remarks on the Play as now represented -Easter Spectacle of "Marco Spada "-Revival of Lord Byron's "Sardanapalus"-" Fly Leaf"-Burlesques-Unfairness of the Practice-Mr. T. P. Cooke at the Princess's-Close of the Season .

CHAPTER IV.

Correspondence between Mr. Charles Kean and Mr. Douglas Jerrold-Mr. Blanchard Jerrold's Statement in his Father's Life-Reasons for publishing the Letters-Their Tendency and Result-Incidental Observations. . . . . . . . . .

\section{CHAPTER V.}

Fourth Season of Mr. C. Kean's Management at the Princess's"Sardanapalus" continued with unceasing Attraction-Sheridan's Comedy of the "Rivals"-The "Lancers," adapted from the French, by Captain L. Vernon, M.P._- A Modern Fashionable Drawing-room"-Article in a Weekly Paper, on the Windsor Theatricals-Statements answered-Large Sums paid for original Dramas-Long and serious Illness of Mrs. C. Kean-Pantomime of the "Miller and his Men"-Revival of "King Richard IIL."-Colley Cibber's Alterations-Great Difference of Opinion on this Point-Reasons for adopting the altered Play-Result not Satisfactory-Supposed Causes - "Married Unmarried"- "A way with Melancholy" and "A Storm in a Tea-cup"-Magical Drama of "Faust and Marguerite"Mr. C. Kean's Mephistopheles - "From Village to Court"-The "Courier of Lyons" produced for Mr. Kean's Benefit-His Performance in the double Characters of Liesurgues and Dubosc -Close of the Season-Number of Pieces performed-Melo. drama and high Tragedy . . . . . . . . . . . 


\section{CHAPTER VI.}

Delayed Commencement of the Fifth Season at the Princess'sCholera in London-Sudden Illness and Death of Mrs. Fitzwilliam-Death of Mrs. Warner- " Living too Fast"-Mr. Douglas Jerrold's Play of the "Heart of Gold "-Comparative FailureSpectacle of "Schamyl, the Circassian Hero"-Pantomime of "Blue Beard"-Casimir de la Vigne's "Louis the Eleventh," adapted by Mr. Dion Bourcicault-Great Sucess of the PlayExtraordinary Impression made by Mr. C. Kean in the Character of the King-Critical Analysis-The Author, the Actor, and the Play-Complimentary Letters to MIr. C. Kean . . . .

\section{CHAPTER VII.}

A "Game of Romps"-The "Nuleteer of Toledo"- "How Stout You're Getting"-Revival of Shakespeare's "King Henry the Eighth," and Return of Mrs. C. Kean to the Stage-Critical Remarks on the Play and Performance-Garrick and Kemble's Alterations of Shakespeare-Mr. C. Kean's Cardinal Wolsey; Mrs. C. Kean's Queen Katharine-Unprecedented Attraction, and Run of One Hundred Consecutive Nights-Acting Superior to Pageantry-Publication of "Henry the Eighth," with Preface and Notes-Restored Scenes and new Stage Arrangements -Condensation of the Fifth Act-End of the Season-Difficulties Surmounted-Concluding Reflections and General Summary

\section{CHAPTER VIII.}

Renewal of Mr. C. Kean's Lease for Four Years-Season of 18551856 at the Princess's-New Farce of "Don't Judge by Appearances-A "Wonderful Woman "-The "Critic"-The "Rivals" -The "Heir at Law"-_"Every One has His Fault"-Mrs. C. Kean as Lady Eleanor Irwin-Pantomime on the Subject of the "Maid and the Magpie"-" Hamlet"-"Jealous Wife""Louis the Elerenth"-" Merchant of Venice"-Death of the great tenor Singer, John Braham-The "First Printer," a new Play by Messrs. C. Reade and Tom Taylor-Arguments on the Treatment of the Subject and its Historical Accuracy-Mr. C. Kean as Laurence Costar-"Faust and Marguerite"- "A Prince for an Hour"-The "Victor Vanquished"-Revival of 
the "Winter's Tale "-Extraordinary Run of One Hundred and Two Nights-Mr. and Mrs. C. Kean as Leontes and HermioneClose of the Season-Mr. C. Kean's Address-Number of Shakespearean Performances-Death of Madame Vestris . . . .

\section{CHAPTER IX.}

Seventh Season under Mr. C. Kean's Management at the Princess's Theatre-Revival of Sheridan's "Pizarro," with Alterations and Additions-Prefatory Notice-Different Opinions as to the Literary Merit of the Play-Mr. and Mrs. C. Kean as Rolla and Elvira-Historical Mistake of Killing Pizarro in the original Play-Great Success of the present Revival-Sixty-eight Repetitions-Next Shakespearean Performance-“A Midsummer Night's Dream"-Early Alterations of this Play-Garrick's Opera in 1763-The Fairies represented by Children-Colman's Adaptation in 1777-Reynolds's Musical Version at Covent Garden in 1816-Madame Vestris's revival at Covent Garden, and Mr. Phelps's at Sadler's Wells-Both ExcellentMr. C. Kean's Restoration of the original Play runs for One Hundred and Fifty Nights during the first two Seasons-The "Rose of Amiens," a Comedy in two acts, and the Pantomime of "Aladdin," both by Mr. J. M. Morton . . . . . . . .

\section{CHAPTER X.}

Revival of "King Richard the Second" by Mr. C. Kean-Previous Alterations of this play by Tate, Theobald, and WroughtonInvariable want of Attraction; attributed to the essentially Undramatic Nature of the Subject-Edmund Kean in "Richard the Second" at Drury Lane, in 1815-Macready in the same Part at the Haymarket, in 1851-Summary of the Play and new Effects as produced by Mr. C. Kean-His Acting as the King-Mrs. C. Kean as the Queen-The Play runs for Eightyfour Nights without Intermission-General Remarks-Revival of the "Tempest"-Close of the Season-Two Hundred and Forty-two Shakespearean Representations .

\section{CHAPTER XI.}

Vacation of Seven Weeks-Mr. and Mrs. Kean visit VeniceThe Theatre opens on the 12th of Oetober-Newly DecoratedThe "Tempest" Resumed-Runs altogether for Eighty-seven Nights-lieproduction of "Richard the Second"-Pantomime 
of the "White Cat"-Death of Lady Boothby, formerly Mrs. Nisbett-Mr. Kean elected a Fellow of the Society of Antiquaries-Festival Performances at the Opera House on occasion of the Princess Royal's Marriage-Absence of MIr. and MIrs. C. Kean-Opinions expressed in the Papers- "Nacbeth" at the Opera House-_"Hamlet" at the Princess's on the same Evening-Demonstration in the Princess's Theatre on the 19th of January-Statement of Facts . . . . . . . . . .

\section{CHAPTER XII.}

Two new Farces, the "Stock Exchange, or, the Green Business;" and "Samuel in Search of Himself," on Easter Monday-Revival of " King Lear" from the Text of Shakespeare-Tate's Alteration - General and Critical Remarks-Death of Mrs. Davison, formerly Miss Duncan-Last Performance at the old Adelphi Theatre in the Strand-Peculiar Style of Audience, Actors, and A uthors-Revival of the "Merchant of Venice"-Novelties Introduced-Mr. Kean's Shylock-Mrs. C. Kean's PortiaGeneral Observations on the Play-Actors of the Principal Characters-The new Prelude of "Dying for Love" . . . .

\section{CHAPTER XIIL.}

Death of the celebrated French Actress, Mademoiselle Rachel at Le Cannet, near Montpellier-Short Summary of her Theatrical Career-Her enormous Profits in a few Years-Her Will and Funeral Obsequies

\section{CHAPTER XIV.}

Proposal for the Establishment of a Dramatic College, or Asylum, for.Decayed Actors and Actresses-Public Mceting in the Princess's Theatre, Mr. C. Kean in the Chair-Report of Proceedings sead by Mr. Cullenford-Speeches by Mr. C. Kean, Mr. Dickens, Mr. Creswick, Mr. T. P. Cooke, Mr. Harley, Mr. B. Webster, Mr. Robert Bell, Sir G. Armytage, Mr. F. Matthews, and Sir W. De Bathe-l'ublished Report of 1858, with amount of Subscriptions-Her Majesty becomes l'atroness -Difference with Mr. Henry Dodd, and final Rejection of his Offer-Death of John Pritt IIarley-Summary of his CarcerClose of the Season at the Princess's-Mr. C. Kean's Address -General Observations. 


\section{CHAPTER XV.}

Mr. C. Kean's Farewell Season as Manager of the Princess's Theatre-"Merchant of Venice" continued-Second Revival of "King John"-Ditto of "Macbeth"-Production of "Much Ado about Nothing"-Mr. and Mrs. C. Kean as Benedick and Beatrice-Farce of "Thirty-three next Birthday"-Pantomime of the "King of the Castle"-_."Jealous Wife"-"Corsican Brothers" - "Midsummer Night's Dream" - "Louis the Eleventh"-"Hamlet" . . . . . . . . . . . . .

\section{CHAPTER XVI.}

Presentation of a Testimonial to Mr. Kean from the Committee of the Dramatic College-Mr. and Mrs. C. Kean's Annual Benefit in 1859-_Last Shakespearean Revival_- "King Henry the Fifth" -Original Effects-Storming of Harfleur-Battle of Agincourt -Introduced Episode of Action-Letters from Historical Authorities-Mrs. C. Kean as the Chorus-Mr. C. Kean as King Henry-Unprecedented Attraction of the Play-Delineation of National Character-Fluellen jdentified with David Gam -Correspondence-New Comedietta, "If the Cap Fits""Henry the Eighth"-Banquet and Testimonial proposed by the Etonians-Notices in the Papers-Congratulatory Letters .

\section{CHAPTER XVII.}

Banquet and Testimonial to Charles Kean at the St. James's Hall, on the 20th July, 1859-Speeches on that occasion-Concluding Summary 
THE

\title{
LIFE AND THEATRICAL TIMES
}

\author{
or \\ CHARLES KEAN, F.S.A.
}

CHAPTER I.

CHARLES KEAN Exters ON THE MANAGEMENT OF THE PRINCESS'S THEATRE IN PARTNERSHIP WITH MR. KEELEY- 'TWELFTH NIGHT' THE OPENING PLAY-THE GREAT EXHIBITION OF 1851-ITS SUCCESS AND OBJECTS - LONDON INCXDATED WITH FOREIGNERS-OPINION OF THE FREXCH OX IENGLISH CHARACTER AND HABITS-DISTINCTION BETWEEX FRENCH AND ENGLISH DRAMATISTS-THE THEATRES CROWDED NIGHTLY THROUGHOUT THE SUMMER-COMPANY ENGAGED AT THE PRINCESS'S THEATRE-OLD PIECES REVIYED-NEW PIECES PRODUCED- THE GAMESTER' ON MR. AND MRS. C. KEAN'S BENEFIT NIGHT-REMAFKS ON THE MORAL TENDENCY OF THE PLAY AND THE LESSONS IT INCDLCATESCOXCLCSION OF THE SEASON-ITS GREAT SUCCESS-RETIREMENT OF MR. MACREADY - HIS FAREWELL BENEFIT AXD PARTING ADDRESS AT DRURY LANE-SHORT SUMMARY OF HIS CAREER-THE CONSPIRACY AGAIXST HIM IN AMERICA.

Is August, 1850, Charles Kean, in partnership with Mr. Keeley, entered on a lease for two years, of the Princess's 'Theatre, in Oxford Street, and for the first time embarked on the "stormy sea" of management. The Keans and the Keeleys formed a rich coalition of VOL. II. 
diversified talent. The progressive events of their experiment were watched with unusual interest, howbeit they had fallen on evil days, and their net was cast in troubled waters. Much was wanting to revive public taste and restore the stage, generally supposed to be on the decline, to its former elevation. Mr. Phelps had already raised the standard of legitimacy at Sadler's Wells, and was making a manly stand; but his scene of action was far east, and too much circumscribed by its locality to divert into unwonted channels the antagonistic tide of fashion. It was felt by all the ardent partizans of our national drama, that unless some compelling force could be applied to counterbalance the thousand and one causes which pressed heavily on its vitality, the most intellectual of all recreations stood in danger of being numbered with the things that were, and the art and its professors might calculate the hour when both should lie down peaceably together, inscribing over their common sepulchre- "Fuimus Troes, fuit Ilium, et ingens gloria 'Teucrorum."

Many of Charles Kean's friends trembled when they saw that lie had determined to risk in the uncertain issue of managerial speculation the fame and fortune which he had toiled to establish by persevering industry from youth to mature manhood. But a favouring presentiment accompanied his name, with a strong impression that the star of his destiny, hitherto so bright, would still continue in the ascendant. He had many and high qualifications for his new work, backed by sound experience. Much reliance was placed on his acknowledged abilities, joined with those of his accomplished lady, their estimation in general society, and irreproachable characters. His known liberality too in his dealings with authors was expected to give an impetus to theatrical literature. $\mathrm{He}$ had already paid 
a second 400l. to the author of the "Wife's Secret," for another play, and was in treaty with several of the leading English dramatists to employ their pens in a similar task. If the genius of Sheridan Knowles slumbered on its laurels and could not be awakened, there were younger disciples of the same school who might aspire to fill his vacant place. In addition to these and other prospects on the favourable side, Charles Kean and his clever coadjutor were backed by a potent allycapital; without which reserve talent and resolution have often been swallowed up and exhausted in the sacrifices necessary to ensure victory. What Montecuculi said of war is quite as applicable to theatrical management. 'The three most essential ingredients of success are money, money, money!

The first season under the new dynasty, at the Princess's, commenced on the 28th of September, 1850, and occupied an uninterrupted period of nearly thirteen months; terminating on the 17th of October, 1851, with the opening play of "Twelfth Night." The net profit amounted to $7,000 \%$. ; but it was the year of the Exhibition, in Hyde Park, and the result cannot be taken as forming any ground for an average calculation.

The Great Exhibition of 1851; might well be called the world's wonder, for such in truth it was. The most perfect realization of a magnificent idea that ever entered the mind of man. The scheme of Henri Quatre for a general peace coalition throughout Europe was scarcely more sublime, and evidently not so practicable. The treasures that were brought together in the Crystal Palace, in Hyde Park, exceeded all that imagination could have anticipated. No such collection can ever be accumulated again, although the shell that contained them has been surpassed in architectural elegance by its more elaborate successor at Sydenham. By crossing from 
one department to another, you were as completely in the country designated, as if the carpet of Prince Houssein had actually annihilated time and space, and carried you there in a minute. You heard its language, saw the complexion of its people, and investigated its productions. The whole formed a scene of realized enchantment, an animated cosmorama, to lose yourself in for a month, without weariness, and to think of for ever after.

A calculation computed on police returns, estimated the number of visitors to the Crystal Palace, during the six months that it remained open, at seven millions. The total receipt of money considerably exceeded half a million sterling, leaving an available balance of 240,000l. The only way of seeing the Exhibition thoroughly and with comfort, was by a season-ticket, of which, as a matter of course, none but residents could avail themselves. You thus took your tine, divided your visit into sections, and examined everything in succession. To-day you were in France, to-morrow in Austria, the day following in Italy, and the next week in India. You then crossed an imaginary Atlantic and glanced over Canada and the United States.

On this plan it required three months, at the rate of several hours per diem, to become acquainted with all the marvels that were submitted to view. A country family arriving by an excursion train, with a return ticket, good for a week, and sometimes only for three days, could obtain little better than a bird's-eye glance, galloping along, catalogue in hand (as Sir Francis Head galloped over the Pampas), reeking with perspiration, and resolved as a point of principle as well as of value received, to toil regularly through the official list of twenty thousand articles.

The predictions of the alarmists were verified to the 
letter during the summer of 1851. London for several months was occupied by the French, but quite in a family way, and without disturbing the entente cordiale. An Englishman wonders how our continental friends contrive to live in so expensive a city as London, knowing that they are not usually endowed with a superfluity of the circulating medium. But there they were, and appeared to enjoy themselves amazingly. You met two foreigners, as you perambulated the streets, for one indigenous child of the soil. They were less mystified by the wonders of the Exhibition than by the total absence of soldiers, the order and peaceable demeanour of the vast multitudes that thronged the thoroughfares, and the perfect ease with which a few hundred policemen managed everything, without any apparent effort. These points of home discipline are utterly incomprehensible to strangers, who are accustomed to behold in every capital of Europe a vast entrenched camp, bristling with bayonets and artillery,-a powder magazine ready to explode with the slightest ignition. They saw Queen Victoria go into the heart of the city, to the Lord Mayor's fête, and return through countless thousands in the middle of the night, with a simple escort of honour. They saw her pass in all the paraphernalia of regal state to prorogue the two houses of Parliament, still only with a few policemen to keep the passuge clear, while all London stood in respectful attendance, cheering and saluting with spontaneous loyalty. Here were evidences of a firmly-based monarchy, a paternal government, a nation satisfied with their institutions, and their power of maintaining them, more convincing than a triple line of fortifications, and a bivouac of troops in every square.

The great London Exhibition, which has been followed by many imitations, was not only the best, but 
had the advantage of being the first. Amongst the remarkable features which distinguished this mighty gathering of the nations, may be noticed the little trouble the police had in keeping order, and the small amount of robbery.

But where were the croakers who prophesied failure, and the constitutional opposers of everything, who thought ("the wish was father to the thought") the building would be gutted by a simultaneous rising of all the socialists, chartists, and red republicans in the world, expressly engaged and congregated for that particular performance?

The impression left on the mind after each successive visit to the Crystal Palace, was one of unqualified admiration, mingled with gratitude to the presiding Providence which crowned this great undertaking with such brilliant success. The blessing which was invoked by the greatest of earthly sovereigns on the inaugural day had been signally vouchsafed. The six months which followed were pregnant with instruction. All was harmony, peace, and good-will. A mantle of protection appeared to be thrown round the vast edifice, from the first opening of its doors. All felt they were entering on a scene devoted exclusively to instructive recreation, where evil passions had no field for their exercise. There was a universal impression that permanent advantages would result, irrespective of the vast additional sums of money that had been brought into circulation, and the many thousands who were thereby enabled to obtain employment. It was estimated that, during the summer of 1851, the average population of London had increased to the amount of 300,000 souls. An intercourse sprang up which had no previous existence. Foreigners, instead of vague surmises, acquired more positive knowledge of us, our habits, institutions, resources, 
and peculiarities, from ocular observation, in that short period of six months, than in the thirty-six years which had previously elapsed since the gates of the Continent were opened on the fall of Napoleon. We had gone amongst them, but they had come sparingly to us. Many prejudices have been abandoned, and many mistaken views have given way, which are not likely again to obtain influence. Our foreign friends have seen and learned that there are better avenues to public prosperity than annual revolutions erected on barricades, and that a government and constitution may be firmly established without a garrison of a hundred thousand men in the capital to compel obedience. The exhibition of the produce of all countries was an honest peace-offering from England to the whole world-a cordial proclamation of amity, unaccompanied by protocols or remonstrances. When the collection began to be dispersed, there ensued much discussion as to the preservation of the building. With many reasons for the retention of Sir Joseph Paxton's magnificent structure, the arguments in favour of its removal prevailed. It may be considered fortunate that they did. Any other course would have been an error. It was erected as a temporary depository for an express purpose, which had been gloriously accomplished, and under the implied condition of being pulled down within a given period.

The whole was a great national event; an epoch in history; a period to date from in the chronology of future annalists. " "I was in the great battle under the walls of Moscow !' This," said Napoleon to his veterans on the morning of Borodino, "will be your proudest recollection when reposing from the toils of service." And often shall we, in the garrulity of old age, repeat to our grandchildren, "I was in London at the Great Exhibition of 1851, and will tell you of all the marvels 
I saw there." The enormous mass of all that the intellect and ingenuity of man could produce of rare and valuable; the discoveries of industry, the triumphs of art, the improvements of scientific invention, brought together with such cost and labour from the remotest corners of the earth, and arranged with such unparalleled skill, have long been scattered abroad, and have passed into the hands of different purchasers, never to be collected again. The daily recurring thousands, whose presence gave life and animated interest to the glowing scene, have subsided back into the sober, plodding tenor of ordinary avocation. The equipages of the royal, the noble, and the refined, no longer throng the surrounding avenues. The ceaseless sound of many voices, the strange blending of many foreign languages, have long been succeeded by unbroken silence. What would have been gained had the building still occupied the vast area, an untenanted monument, an empty reminiscence, a casket stripped of the treasures it was constructed to enclose? The historic records, the practical influence on civilization, the increase of commercial intercourse, are more enduring and more satisfactory memorials of the mighty bazaar, than the Crystal Palace transformed into a winter garden, or a gigantic hippodrome. Devoted to such purposes as these (which were the most favourite propositions for its conversion), it might have been useful and ornamental, but would have ceased to be a connecting link with the object which called it into existence. It would have resembled the funereal pyramid of: Cheops, without the ashes of the founder; the mausoleum without the relics of the hero it was intended to preserve; or the mere outward case of the watch, divested of its costly and complicated machinery. Better that all should be removed, than that a mutilated skeleton should be retained. There may be something of barbarisnr, 
but there was grandeur in the obsequies of Alaric, the conquering Ostrogoth. His devoted followers, by the labour of their prisoners, forcibly diverted the course of the Busentinus, near Consentia, erected his sepulchre in the empty bed of the river, piled over his mortal remains the accumulated treasures and memorials of many conquered nations, including those of Imperial Rome; and then turned on the stream again to engulph the monarch and his trophies, that no vestige of either might remain as tangible evidences, after the soul which gave them reality, and power, and substance, had been summoned back to its account. The immortality of the Exhibition was not dependent on the mutation or breaking up of the building in which it had been contained. It rested with the historian, the painter, the engraver, and the consequences to be transmitted through succeeding generations.

Foreign visitors are invariably struck with the extent and enormous population of London; with the building mania that extends on every side, and seems likely to continue until the whole county of Middlesex is covered with brick. But a general impression seems to exist, more especially amongst the French, that England altogether, without reference to climate, is un pays tristea dull country to live in. A Parisian carries the same gay indifference to the "Bourse" with which he enlivens the drawing-rooms and coffee-houses. John Bull cannot do this. With him, the Stock Exchange is the serious business of his life. He has no idea of mixing up a laugh, or a trifling anecdote, with monetary calculations. But his mistake is, that he cannot leave his commercial face at home when he mingles in society, or locked up in the desk with his scrip and debentures. He enjoys himself with an effort; and whether he is dancing, playing cards, or enduring music, appears very much as if he was thinking of something clse. If you tell him a 
joke, he laughs at the end as a matter of duty and politeness, but seldom looks as if he were listening. He lias, usually, what the French call l'air préoccupé, and which they consider, not without cause, the very antipodes of relaxation. He cannot give himself up, heart and soul, as they do, to the influence of the moment. This is one leading reason why our national drama-which is always, to a certain extent, a reflex of national character-with more nerve and vigour, has far less ease, variety, and piquancy than that of our volatile neighbours. It is not that our writers are deficient in sparkling wit or broad humour. The comedies of Congreve, Farquhar, Goldsmith, Sheridan, Colman, Morton, and various living authors, attest the contrary; but their telling points are mostly got up for the occasion, and worked off with labour; as professed diners-out prime themselves with their best stories for public display, when they appear all fun and sparkle. But if you catch then at home in undress, they have a look of habitual melancholy, while their gibes and mockeries are as threadbare as their dressing-gowns. In fact, we often assume gaiety without any feeling of mirth; while the French laugh constitutionally at the most solemn matters, as forming a portion of what they please to consider the burlesque of life. Let us be content to keep our gravity, coupled with the national reproach of heaviness, rather than run into the opposite extreme.

During the summer of 1851 , there were nineteen theatres open in London, exclusive of the two Italian operas and the St. James's, devoted entirely to French tragedy and comedy. This list applies to quasi-legitimates only, and has no reference to hippodromes, gardens, casinos, Grecian saloons, and the thousand and one irregulars which swarmed in every corner of the city and suburbs, and where dramatic performances, 
under some form or other, were represented daily and nightly. Nearly all reaped an abundant harvest, principally gathered in from the visitors and foreign strangers; although throughout the month of May there was an alarm of failure, and managerial faces elongated in proportion. But the panic was momentary, and from June onwards a reactionary tide set in, which never ebbed again, but filled the theatrical treasuries, with two or three exceptions, even to overflowing.

In Fraser's Magazine for August, 1851 (No. 260), it was stated that the theatres were empty, that the managers had proved themselves bad calculators in expecting they would be filled; that our dramas were not formed on the models suited to the taste of continental audiences; and that the Exhibition afforded reason enough for "a beggarly account of empty boxes," as neither foreigner nor native could sit out a play on a hot evening after a long day devoted to the wonders of the Crystal Palace.

While this was elaborately set forth for the edification of country readers, nightly facts obtruded themselves in direct refutation. All the theatres were so crowded that it was difficult to obtain squeezing room. More than half the plays exhibited mere adaptations or translations from the French; while at least five-sixths of the audiences were composed of foreigners and holiday excursionists from the country. That the same pieces were repeated night after night with little thought of varicty, was a tolerable proof of continued attraction, and also that the attraction rested with the strangers. The resident play-goers were compulsively banished by the "hundred and fitty-fourth night of the "Alhambra," " the "two hundred and twenty-third of 'King Charming,' " and the "thrce hundred and thirty-first of "Green Bushes.' "

The company collected for the opening of the 
Princess's Theatre, in Sept. 1850, included the following names: Messrs. C. Kean, Keeley, Harley, Bartley, Wigan, Meadows, Ryder, Fisher, King, Bolton, Cathcart, Addison, Flexmore; Mesdames, C. Kean, Keeley, Winstanley, Wigan, Daly ; Mesdemoiselles, Phillips, C. Leclercq,- Robertson, Murray, M. Keeley, and Desborough. During the first season, the Shakespearean plays represented were as follows:-_"Hamlet," fourteen times; "Twelfth Night," forty; "As You Like It," four; the "Merchant of Venice," twelve; and "Henry the Fourth" (Part I.), twenty-two. The "Wife's Secret," commanded twenty-six repetitions ; the "Gamester," fourteen ; the "Prisoner of War," thirteen; the "Stranger," seven; and "Town and Country," four. The principal novelties were, the "Templar," and the "Duke's Wager," by Mr. Slous; "Lost in a Maze," by Mr. Bourcicault; and a romantic drama in the melo-dramatic line, of a very peculiar character, skilfully adapted from the French, by Mr. John Oxenford, entitled "Pauline." In the latter, the powerful acting of Mr. and Mrs. C. Kean, in two well contrasted original parts, elicited universal approbation. The situations in this drama are dangerous and revolting. Nothing but the most artistic delineation, regulated by good taste, could have rendered them endurable to any English audience. There were also six light farces, namely, "Platonic Attachments," "A Model of a Wife," "Sent to the Tower," "Betsy Baker," "To Parents and Guardians," and "Apartments to Let ;" with the pantomine of "Alonzo the Brave," by Mr. Fitzball, and the burlesque spectacle of the "Alhambra," by Mr. Albert Smith, produced at Easter and continued without interruption to the close of the season. The total number of pieces acted amounted to twenty-seven, of which twelve were entirely new. 
In the early part of the season, Her Majesty engaged a box, which she has retained annually ever since, and still more satisfactorily marked her approbation of the theatre by constant personal attendance.

On the occasion of their benefit, Mr. and Mrs. C. Kean appeared in the "Gamester," and "Honeymoon"- the same bill which had been selected ten years before, in Dublin, on the day of their marriage. The performance was received with enthusiasm by a house crowded to the roof, and elicited long articles of encomium from the leading papers. The characters of $M r$. and Mrs. Beverley have always been popular with the leading performers of their day. Mr. and Mrs. C. Kean had been accustomed to act their principal parts together for many years during their tours in the principal country theatres, and their later engagements in London. They thus acquired a power of producing combined effects by long study and practice-a perfection of art which strangers cannot reach, who only meet at accidental intervals in professional life, and have no harmony of thought or reciprocal feeling, in conception of character. By constant association, they were enabled to act up to each other with a certainty of perfect co-operation, tending greatly to the advantage of the play represented, which we have often secn marred and weakened by a want of this complete understanding between the parties on whom the weight and interest almost entirely rest. We can recall no instance in which the value of mutual support more forcibly demonstrates itself than in the performance of Beverley and Mrs. Beverley by Mr. and Mrs. C. Kean. The most captious critic would have been puzzled to detect an oversight or suggest an improvement in their personification of these two characters. Nothing was wanting to the completeness of the picture, and nothing over- 
looked from the beginning to the end. We were not startled by a momentary flash of brilliancy, followed by half an hour of unexciting tameness. All was sustained, equal, and impressive, with every varying shade of passion justly discriminated. Mrs. C. Kean is peculiarly suited to Mrs. Beverley, uniting with a natural elegance of manner, refined sensibility and unaffected pathos. Her never varying affection for her husband under all trials, her perfect confidence in his heart notwithstanding the errors of lis head, were beautifully portrayed. In a character so carefully studied by several generations of highly-gifted actresses, it is not easy to strike out new effects, or to introduce untried readings. To deviate from what has been done before, merely to avoid comparison or for the temptation of novelty, is not only injudicious, but opens a dangerous avenue to failure. Mrs. C. Kean's conception and execution of this part were consistent with sound taste and judgment. She is neither a copyist nor an unnecessary innovator. Her general style is not formed on any particular model or school, but follows nature, the great teacher and master of all. Her reply to Stukely's insinuations against Beverley's fidelity, contained in the words, "I'll not believe it," was one of the most powerfully original points we ever saw delivered. The whole of the scene with Stukely, and her last interview with Beverley when he is dying in the prison, absorbed the attention of the audience between mingled plaudits and tears, to an extent of which the modern stage affords but few examples.

Some amongst the surviving residue of the old playgoers, who exist on reminiscences of the past, and have little sympathy with living pretensions, speak with rapture of the "astounding sensation" produced by Mrs. Siddons in Mrs. Beverley. Nothing, they say, 
could ever approach the manner in which she uttered the simple sentence, "Mistaken had been kinder;" or her entire scene where she rejects the overtures of Stukely; or her exclamation in the fifth act to Jarvis,"Tis false, old man," \&c. ; or her hysteric laugh, and look of fixed despair, at the death of Beverley. All this may be true to the letter, as to the effect produced, but it ought not to incline us to undervalue the talents of the artists we possess, or lead us to forget that acting was considered more miraculous, was more fashionably followed, and much more fervently applauded, fifty years ago, than it is now. An apathetic chill has damped the spirit of recent audiences, which tames down the fervor and intensity of the most impassioned performers, checks their confidence in themselves, and often paralyzes their most powerful efforts. Dr. Johnson remarks, with great truth, in his preface to Shakespeare:- "All, perhaps, are more willing to honour past than present excellence; the great contention of criticism is to find the faults of the moderns and the beauties of the ancients. While an author is yet living, we estimate his powers by his worst performance, and when he is dead, we rate them by the best." What is here applied to authors only may be readily extended to actors and artists in general. A statue is often raised to the buried merit, which, when alive, was scarcely recognized.

Not many years since, a short time only before the revival of the "Gamester" at the Princess's, when it was acted at the Haymarket and other theatres in London, more than one critic in the daily papers rolunteered a crusade against the play itself. It was called obsolete, old-fashioned, common-place, vapid, prosy, out of date; we are not sure that twaddling was not amongst the disparaging epithets. The subject was pronounced 
too exciting; the catastrophe too harrowing for the feelings; while the weakness of Beverley rendered him too contemptible for sympathy.

All this was easily written, had an imposing aspect in print, and may have passed current with hundreds of mere casual readers who are caught by a novel and intrepid assertion, without troubling themselves to inquire through what mode of reasoning it can be proved. To us, the "Gamester" has always appeared a moral lesson worthy of the pulpit, a domestic tragedy of the highest order. Simple, powerful, effective, and probable in the construction of the plot; clear, intelligible, nervous, and pathetic in the dialogue. A leaf from nature's book, applicable to all times, and all countries; not a page from the registry of any particular manners, or a record of any passing absurdity which may command its votaries to-day, and is totally forgotten to-morrow. The characters appear to be made for the situations they are placed in, and the incidents develop themselves naturally as if produced by the characters.

if A vice is here held up to detestation, with all its appalling consequences, more absorbing than any other, which has brought greater desolation to the hearths of families, and has entailed more misery on the descendants of those who have thus immolated themselves on the altar of that destroying Moloch, than human weakness, tyranny, and depravity, have ever produced in any other shape, or through any other agency. As Dr. Young observed, "the fatal prevalence of gaming required such a caustic as the concluding scene of this play presented." The very want of resolution and consistent firmness in Beverley, the readiness with which he falls into the snares of his tempter and evil genius; those very points which have been somewhat hastily objected to, consti- 
tute the strong truth, the reality, the interest, and above all, the moral warning of the story. Of ten average men, nine are weak in some particular instance. This is the besetting failure of humanity, and this natural weakness often engenders more mischief than positive crime. The absolutely wicked are few in number compared with the victims they entangle, without whom their power for evil would be circumscribed almost to nullity. They would die for lack of sustenance, or be forced to prey upon each other, and become extinct for want of necessary food to keep their restless faculties in action. The moral teacher keeps back the more valuable half of his lesson if he suppresses the power of bold iniquity in operation on the irresolutely virtuous. As men are constituted (and who is to change their organization?), the number who resist successfully is far exceeded by those who sink when strong temptation presents itself. To deny sympathy to the fallen, is to close the volume of our own humanity and to fly to ideal standards which cease to be instructive because we know them to be fictitious. We must study man as he is, if we desire or expect to extract profit from his example, either in folly or in wisdom, in error or in excellence.

It was also quite bewildering to be told that the last scene of any tragedy could be too harrowing or exeiting for the taste of an age which positively revelled in the monstrous exaggerations of French melodrama and German metaphysics, the most extravagant flights of which were eagerly acknowledged and hailed with rapturous evidences of enjoyment. If the most salutary elements of legitimate tragedy are not impressively embodied in this fine play, we shall really feel indebted to some more sublimated discoverer who will enlighten us as to where they are to be found and in what they consist.

VOI. II. 
Charles Kean's Beverley was in every respect worthy of his gifted associate. It was, perhaps, his very best assumption, up to that time, out of the Shakespearean range. His attitude of deep despair, and the expression of his countenance when first discovered, furnished an index and an unmistakeable prologue to what was to follow. Before the actor had spoken a dozen lines, the audience penetrated his masterly conception of the character, and were prepared for all the thrilling incidents which form the sequel, and rise on each other in rapid succession. The scene in the gambling-house with Stukely, in the third act, after he had ventured and lost his last resource, was given with overwhelming power. To call it impassioned is to speak faintly. It was an absolute whirlwind, a sweeping tempest of ago. nized frenzy, bearing down all before it, and produced an effect on the audience which proclaimed its terrible reality. His dying struggles in the last scene were equally impressive. One of the distinguishing characteristics of his style is the identity with which he marks his stage deaths, according to the causes and circumstances under which they are supposed to take place. A cold, calculating observer, who can think and write that the fate of Beverley excites no commiseration, has never seen the part embodied by Charles Kean, or has schooled himself into an insensible, iron stoicism, which sets feeling at defiance, laughs at the calamities of life, and, as Shakespeare says, "makes a pish at chance and sufferance." We envy not the frigid philosophy or callous indifference which could look on such acting, in such a drama, without deriving benefit from the "salutary woe" which Dr. Johnson emphatically describes as the test and triumph of the tragic muse. Even the cruel tyrant of Pheræa wept at a tragedy of Euripides; and we doubt if any one, however possessed by the passion of 
play, could witness the "Gamester" without a determination to reform.

The partnership between Messrs. Keeley and Charles Kean terminated by mutual arrangement, before the theatre re-opened for the next season. The former, with his talented lady, remained members of the company, but the latter was announced as the sole manager.

Amongst other "memorabilia" which marked the year 1851, we must enumerate the retirement from the stage of William Charles Macready, who, during his long London career of thirty-five years, had always filled a prominent, and latterly a commanding situation. $\mathrm{He}$ went through a succession of farewell performances at the Haymarket during the early part of the winter, and, on the 26th of February, closed with his final benefit at Drury Lane, selecting Macbeth for his last appearance. In his parting address, he spoke fervently of the public support which had cheered him through many difficulties, and enhanced the happiness of his life. "The lapse of time," he said, "has not dimmed the recollection of the encouragement which gave impulse to the inexperienced essay of my youth, and stimulated me to persevere when struggling hardly for equality of position with the genius and talent of the great artists whose superior excellence I ungrudgingly admitted, admired, and honoured." Following the example of Young, he ceased from his labours while his strength was yet entire, and for the same reason. "Because," he concluded, "I would not willingly abate one jot of your esteem, I retire with the belief of yet unfailing powers, rather than linger on the scene, to set in contrast the feeble style of age with the more vigorous exertions of better years." Soon after his retirement, he was honoured, as his great predecessor John Kemble had been, with a public dinner, and the presentation of a testimonial. It was the second time he 
had received a similar compliment-the first having been conferred upon him on his secession from the managerial sceptre of Covent Garden, in 1839.

Macready practised in an excellent school, and long stood side by side in honourable competition with all the greatest performers of his day. He followed no previous style, but with the boldness of a strong mind, created one for himself; peculiar and startling, not eminent for grace, but thrilling with effect. Nature had endowed him with a noble voice, and study gifted him with the resources of elocution. He was often accused of mannerism, but this charge, of somewhat vague definition, may lie against almost every artist who has attained distinguished eminence. James Kenney, the dramatic author, was fond of maintaining that an actor ought to be a mannerist, provided the manner was good and original. Whether by direct teaching, or the reflected fascination of example, Macready engendered a host of imitators, none of whom have emulated the reputation of their model, or upheld the strong personality which stamped his conceptions. They were for the most part, servile and offensive, where he was powerful and original. It is satisfactory to think that the breed tends to extinction rather than increase.

Even to his concluding season, it continued to be a debated question whether Macready was, in the enlarged sense, a first-rate representative of first-rate Shakespearean characters. But on the subject of his managerial efforts to advance the interests of the legitimate drama, and to illustrate worthily the works of our grcat poet, there has been but one decision-that of the warmest praise. He proved himself a valuable pioneer, opening avenues untrod before; and would in all probability have advanced much farther, had the encouragement kept pacc with the outlay. It has been 
frequently stated in conversation, and reiterated in print, that during his four years' management, of two seasons in each term, at the two great national theatres, he suffered in his fortune to the amount of 10,000l. Such a result, supposing it to be an approximation to the truth, was sufficient to check the most enthusiastic spirit, and impresses a conviction that the public were not yet prepared for the complete revolution which Mr. Charles Kean has since effected.

The modern drama is almost identified with the name of Macready: Knowles, Bulwer, Talfourd, Shiel, and Byron, may claim him as their predominant illustrator. While the works of these popular writers retain their hold on the living generation, the memory of his acting in Virginius and William Tell, in Ion, Werner, Claude Melnotte, and Cardinal Richelieu will also be recorded with corresponding admiration.

Macready twice visited France professionally; Amcrica three times. Of all the English tragedians, he proved to be the leading favourite with the Parisians, and his great profits in the United States evinced the popularity he enjoyed throughout the transatlantic continent. His third and last tour was curtailed by the unexpected riot at New York, in May, 1849, fomented, as is generally believed, by Edwin Forrest, who, whether deservedly or not, has thereby linked himself to a notoriety, as unenviable as that of Erostratus; and even more criminal, for instead of the temple only, his madness involved the destruction of the worshippers. If Forrest had any part, directly or indirectly, in that savage and unmanly tumult, which drove Macready from America, and caused the sacrifice of many lives, he has much to answer for.

Mr. Macready carried with him to the privacy of his domestic circle, a love of classic lore and studious habits, 
resources for the evening of life which ordinary casualties have no power to diminish. But his hearth has been unexpectedly desolated, and his household deities rudely shivered round him. Gaps have been formed which never can be filled up again. These sad visitations have called forth the unmingled sympathy which has been universally felt and acknowledged. 


\section{CHAPTER II.}

THE PRINCESS'S THEATRE UNDER THE SOLE MANAGEMENT OF MR. CHARLES KEAN-THE SEASON COMMENCES WITH THE MERRY WIVES OF WINDSOR -CAST OF THE COMEDY-CRITICAL OBSERVATIONS-KING JOHN, THE FIRST GREAT HISTORICAL REVIVAL - MRS. SIDDONS'S REFLECTIONS ON THE CHARACTER OF CONSTANCE-THE CORSICAN BROTHERS-MANY VERSIONS AND BURLESQUES OF THE LATTER-ITS GREAT ATTRACTIONS AT THE PRINCESS'S-SUPERNATURAL AGENOT - WELL ACTHENTICATED OHOST STORIES-MADEMOISELLE CLAIRON'S DISEMBODIED PERSEOUTOR-TENDER PRECAUTIONS-OUR CLERKS-THE EASTER SPECTACLE, WITTIKIND AND HIS BROTHERS-MR. LOVELL'S PLAY OF THE TRIAL OF LOVE-THE PHANTASM OF THE VAMPIRE-THE PANTOMIME OF BILLY TAYLOR-CLOSE OF THE SEASON ON THE 14TH OF JULY-NUMBER OF PIECES PERFORMED - GENERAL RESULT.

On Saturday, the 22d of November, 1852, the Princess's Theatre re-opened under the sole direction of Mr. Charles Kean, with Shakespeare's "Merry Wives of Windsor," divested of the operatic and textual interpolations by which it had been too long disfigured. It now became once more what the author had constructed it for-a legitimate comedy, with a rich assemblage of well-contrasted characters, leading naturally to a quick succession of incidents arising from the situations as they occur. The fine, racy dialogue was no longer impeded by the introduction of bravuras, interminable duets, and flourishes, so interwoven in labyrinthine mazes, that it appeared impossible for the singers ever to get out of them ; and made the audience almost echo Dr. Johnson's wish, that such painful vocalism had been impossible. Even more misplaced was the similar attempt to operatise the "Comedy of Errors," the whole effect of which 
depends on the rapidity with which the action is carried on, and the perpetually recurring entrances and exits of the persons mistaken for each other.

A clever journal, in congratulating the public on the banishment of music from the present revival of Shakespeare's witty comedy, observed:- "Only fancy the arch and perplexing rogueries of the frolicsome dames upon amorous Old Jack interrupted every five minutes by warbling information that

- Crabbed age and youth

Cannot live together ;'

and by reminding us of the old proverb,

'All that glitters is not gold.'

Imagine, if you can, characters which ought to be sustained by actresses of first-rate comic talents, in the hands of English prima donnas; and, to complete the absurdity of the contrast, the accepted lover of sweet Anne Page personated by a gigantic or punchy tenor, who stops the action of the play at the exact moment when it is worked up to a point, to sing to you the pleasing intelligence that

'The winter it is past,

And the summer's come at last ;'

to impart in tuneful obscurity substituted for words that 'the wintry wind' is

\section{'Not so unkind \\ As man's ingratitude ;'}

and in 'sweet sounds' to make you acquainted with the pleasing fiction that

'A lover's eyes will strike an eagle blind.' "

The subjoined cast of the play will furnish an idea of the manner in which the restored text of Shakespeare was given at the Princess's on this occasion:-Falstaff, Mr. Bartley; Ford, Mr. C. Kealı ; Page, Mr. J. Vining; 
Fenton, Mr. J. Cathcart; Shallow, Mr. Meadows; Slender, Mr. Harley; Sir Hugh Evans, Mr. Keeley; Doctor Caius, Mr. Wigan; Host, Mr. Addison; Bardolph, Mr. Wynn; Pistol, Mr. Ryder; Nym, Mr. F. Cooke; Mrs. Ford, Mrs. C. Kean; Mrs. Page, Mrs. Keeley; Anne Page, Miss Mary Keeley; Mrs. Quickly, Mrs. Winstanley.

The same paper from which we have quoted above, and which, under a changed dynasty, subsequently became one of Charles Kean's bitterest assailants, contained the following encomium on his performance of Ford:- "We have never seen this character so ably conceived, or executed with such masterly skill. The nervous, irritable manner he displayed in the scene where he induces Falstaff to undertake his mission to Mrs. Ford gave ample evidence of how deeply and correctly $\mathrm{Mr}$. Kean has studied the peculiarities of the jealous husband. It was one of the best pieces of nature we have for some time seen displayed, and as such was felt and appreciated by warm applause." Actors of high standing, John Kemble included, were wont to deliver the part of Ford in a tone of measured, solemn declamation, forgetting that the extraordinary phase which jealousy assumes in this eccentric humorist is as distinct from the tragic passion of Othello or Leontes as the wit of Falstaff is from the pathos of Lear. The effect here is to be produced by comic extravagance. of manner and utterance, in keeping with the still more extravagant suspicion, which becomes utterly incongruous when coupled with a staid, collected demeanour. Those who are old enough to remember Wroughton in Ford have

* Richard Wroughton (a native of Bath) retired in 1515. A secondclass actor in general, with strong physical deficiences, but occasionally inspired to excellence, as in Ford ; Darlemont ("Deaf and Dumb"); Sir John Restless ("All in the Wrong"); and Apemantus, in "Timon of Athens." 
seen what Shakespeare intended and Charles Kean revived.

The "Merry Wives of Windsor" ran for twenty-five nights, and then made way for "King John," produced on the 9th of February, 1852. This may be considered the new manager's first great attempt on the plan he has since carried out with such indomitable perseverance and triumphant success. He had long felt that, even by his most eminent predecessors, Shakespeare in many respects had been imperfectly illustrated. $\mathrm{He}$ had seen what earlier actors and managers had accomplished. He felt that steps had been taken in the right direction; and longed ardently to press farther on in the same path, to a more complete end. No longer fettered by restraining influences, and confident in the result, although previous experiments were attended by failure, he entered boldly on the enterprise. The result is before the public. It has worked a total revolution in the dramatic system by the establishment of new theories and the subversion of old ones. The time had at length arrived when a total purification of Shakespeare, with every accompaniment that refined knowledge, diligent research, and chronological accuracy could supply, was suited to the taste and temper of the age, which had become eminently pictorial and exacting beyond all former precedent. The days had long passed when audiences could believe themselves transported from Italy to Athens by the power of poetical enchantment without the aid of scenic appliances.

In addition to the managerial credit which Mr. Charles Kean established by this early effort, and the still higher expectations he gave birth to from the manner in which "King Joln" was placed before the public, he made an important step in his reputation as an actor of the first class by a very complete and well-studied 
embodiment of the principal character-one of the most difficult, and perhaps altogether the most repulsive on the stage. There is nothing to assist the representative -no taking qualities, no commanding energy, no brilliancy, even in crime. All is sordid, contemptible, gloomy, and ferocious. Yet there is dramatic strength in this craven monarch, as Shakespeare has drawn him, which has commanded the attention of the greatest tragedians. Old stage records tcll us how the "shining lights" of other days acquitted themselves in this arduous part. According to them, Quin lumbered painfully through, growled some passages, bellowed others, and chanted the rest. Churchill, in the "Rosciad," sneers at Mossop for brow-beating the French King, and says the poor tame monarch seemed in danger of being swallowed up by his voracious brother of England. Sheridan the elder was pronounced too monotonous; Powell deficient in weight, and Holland exuberant in noise. Garrick never could entirely satisfy himself in the part, and alternated between John and Faulconbridge, without reaching perfect mastery in either. Had his fire and spirit been trebled, he lacked the six feet and the thews and sinews without which Faulconbridge cannot satisfy the eye of the spectator. John Kemble's performance of the King was considered faultless; Young, following in the track of Kemble, played it with almost equal effect. Many estimated it as Macready's best Shakespearean attempt; and in Charles Kean's list it may perhaps take the fifth place, giving precedence to his Hamlet, Lear, Wolsey, and Shylock.

The force of poetical genius is wonderfully exhibited in compounding a stage hero from such unpromising materials. Unlike his kindred of the house of Anjou, who were generally remarkable for gigantic proportions and a gallant bearing, John was as insignificant in form 
as he was timid and grovelling in mind. His stature, when the skeleton was measured on the opening of the tomb in Worcester Cathedral, proved to be diminutive almost to dwarfishness ; but his capacity for crime was illimitable. He was all gloom, without a scintillation of light, or a momentary interval of relief. Jests have been recorded of Tiberius and Caligula; Pope Alexander VI. and Louis XI. had within their dark spirits a germ of diabolical humour; but the features of John Lackland were never known to relax into a smile, or his tongue to give utterance to a mirthful sentiment. The scene where he darkly suggests the murder of Arthur to Hubert, and the terrible agonies of his death, are trying tests of the actor's power, in which he can raise no sympathy, and must extort applause by such life-like touches of painting as none but a great master can elicit.

In the Lady Constance, Mrs. C. Kean stepped out of the line peculiarly recognized as her own, and assumed a character of matronly dignity and agonizing passion, which had been supposed to tax to their utmost the surpassing energies of her greatest predecessor, Mrs. Siddons. She had performed the part with universal approbation in New York, but had not yet ventured it in London. It was a hazardous undertaking, with the reminiscences attached to it. The result completely took the public by surprise. Never was a character represented with more true feeling and natural pathos; with more convincing evidence of careful study, or a more complete demonstration of having thoroughly caught up the spirit of the author. If Mrs. Siddons filled her audience witl superior awe, Mrs. C. Kean drew more largely upon their tears. Campbell says, in his "Life of Mrs. Siddons," that it was not unusual for spectators to leave the house when her part in the 
tragedy was over, as if they could no longer enjoy Shakespeare himself when she ceased to be his interpreter. This sounds very like a poet's hallucination. The sentence reads with an imposing air, but we have never heard it corroborated. Constance disappears from the scene in the third act. We find it impossible to believe that any one would lose two-fifths of a fine play, and take so little interest in the general subject, as not to wait for the catastrophe. What the biographer quotes as the great departed representative's own impression of the character is of higher value, and comprises a useful lesson on the importance of abstraction in the art of acting. In the memoranda left behind her, Mrs. Siddons says :- "Whenever I was called upon to personate the character of Constance, I never, from the beginning of the play to the end of my part in it, once suffered my dressing-room door to be closed, in order that my attention might be constantly fixed on those distressing events, which, by this means, I could plainly hear going on upon the stage, the terrible effects of which progress were to be represented by me. Moreover, I never omitted to place myself, with Arthur in my hand, to hear the march, when, upon the reconciliation of England and France, they enter the gates of Angiers, to ratify the contract of marriage between the Dauphin and the Lady Blanche; because the sickening sounds of that march would usually cause the bitter tears of rage, disappointment, betrayed confidence, baffled ambition, and, above all, the agonizing feelings of maternal affection, to gush into my eyes. In short, the spirit of the whole drama took possession of my mind and frame, by my attention being incessantly riveted to the passing scene."

A strange contrast to this refined conception of the study that great acting requires, is presented by the 
habitual carelessness of Mrs. Pritchard, a tragic actress who, until Mrs. Siddons appeared, stood first on the list. It is recorded of her, that she never read more of the play of "Macbeth" than her own part, as furnished by the prompter; and was perfectly astonished when Garrick purified it of the interpolations of Davenant, and restored the original text.* Quin, also, observed with indignation, "What does little Davy mean by all this nonsense about a new version? Don't I act Shakespeare's Macbeth?"

The carelessness and liabitual confidence of the young pillars of the drama of the present day, would do well to pause over Mrs. Siddons's memoranda, and other valuable precepts which have been bequeathed for their instruction; provided they will condescend to profit by them. They are greedy enough of celebrity, but dislike the study by which only it can be acquired. They look aspiringly to the top of the ladder, but are apt to forget the laborious instalments by which it is to be reached.

Ten years before the production of "King John" at the Princess's, Mr. Macready had revived the same play, with much appropriate pomp, at Drury Lane. His field of action was larger, which gave him many advantages; but in accuracy of detail, the second representation surpassed the first. From the list of authorities, named in the play-bill as having been consulted by Mr. C. Kean, an idea may be formed of the amount of reading and research necessary to produce the perfect restoration which was aimed at and attained. The public see the result. They are satisfied, surprised, and excited to vehement applause. But they do not sufficiently appreciate, and, perhaps, scarcely understand, the ability and industry by which, in three hours, they have gathered in a store

* According to Dr. Johnson, Mrs. Pritchard was vulgar, illiterate, and spoke bad English. 
of information which years of laborious study could alone convey to them through any other channel.

Before quitting the subject of "King John" at the Princess's 'Theatre, it would be unjust not to name, in a special sentence of approval, the impressive acting of Miss Kate Terry, then a child of ten years of age, as Prince Arthur, and of Mr. Ryder as Hubert. Hubert is subordinate in rank; but he stands in prominent situations in the play, and requires an actor of weight and judgment. Unless he plays up to the King in the scenes in which they appear together, especially in the third act, the effect will go for nothing. George Frederick Cooke, after his great London success, sustained this apparently second-rate character with John Kemble, and won more applause than was anticipated, although placed far below his mark. Bridgewater was the Hubert in Quin's time: a painstaking actor, and a thrifty man, who combined the opposite trades of a vendor of coals and a disciple of Thespis. One night, after the scene in the fourth act, upon going into the green-room, Quin took him by the hand, and thanked him for his earnest support on that particular occasion : "for sometimes, you know, Bridge," said he, "that, in the midst of a most important scene, your ideas wander to your coal-wharf, and you are thinking less of Shakespeare than of measuring out a bushel of coals to some old crone, who looks as if she would never pay for them."

A fortnight after the production of "King John," the performances were varied by another specimen of the French modern school, even more peculiar than its predecessor, "Pauline," and destined to a much more enduring attraction. In this instance, the supernatural was most ingeniously and effectively blended with the romantic. We allude to the far-famed "Corsican Brothers," who 
were first transplanted to the London boards on the 24th of February, 1852. This singular drama ran sixty-six nights during the first season; and has been repeated, in all, above two hundred and seventy times. No sooner did it receive the stamp of current fashion at the Princess's, than nearly every theatre in the metropolis brought forward versions of their own. For a time, the subject became a perfect mania; and, as a matter of course, was burlesqued. There can be no safer criterion of success than ridicule. No opera can be said to have made a hit, unless the telling airs are ground on barrel organs at the corner of every street, and parodied by itinerant ballad-singers. The taste which enjoys and encourages travesty, though participated in by many, is certainly not of an elevated order. When it invades Shakespeare, it ought to be denounced as sacrilege, and inspires a wish for a special act; or, that the outraged bard could obtain a day rule, and come back in the flesh to carry off the perpetrators bodily to condign judgment in some penal limbo, created expressly for the purpose.

As regards the "Corsican Brothers," nothing could be better than the acting of Mr. Charles Kean in the characters of the imperturbable, self-collected Fabien, and the gentler Louis dei Franchi; and nothing could be more real and exciting than the masqued carnival at the Opera House in Paris. But, still, the piece owed much of its extraordinary success to the Ghost, with the novel and appalling manner in which its agency was introduced.

Unquestionably, there is comfort and consolation, blended with positive enjoyment, in a well-authenticated ghost story. In spite of the advance of practical utilitarianism, with the accompanying decline of romantic feeling, few are willing to give up Sir George Villiers, 
Mrs. Veal, Lord Tyrone, Lord Lyttleton's dove and white lady, or the stern half-pay Major who appeared to his old friend and comrade, to reprimand him for suffering his favourite sword to get rusty. All the world listens with interest to these and similar records. There is a fascination in a tale of supernatural horror, which philosophy can no more explain than it can withstand. The credulous followers of spirit rapping and clairvoyance, the dupes of calculating impostors, are poor representatives of this genuine faith.

More people believe in ghosts than choose to acknowledge their credulity. Even scoffers tremble while they pretend to laugh. Let us remember what the sage Imlac says, in "Rasselas:"- "That the dead are seen no more I will not undertake to maintain, against the concurrent and unvaried testimony of all ages and of all nations. There is no people, rude or learned, amongst whom apparitions of the dead are not related and believed. This opinion, which, perhaps, prevails as far as human nature is diffused, could become universal only by its truth. Those that never heard of one another would not have agreed in a tale which nothing but experience can makc credible. That it is doubted by single cavillers can very little weaken the general evidence; and some who deny it with their tongues confess it by their fears."

There are, it must be admitted, two damaging points connected with ghosts, in respect to the fulfilment of their mission. They cannot take the initiative in dialogue, thcy can only speak when they are spoken to; and in nincteen cases out of twenty, they frighten those to whom they appear to such an extent, that they render them tongue-tied and paralyzed.

Mademoiselle Clairon, the celebrated French tragic actress, the rival and contemporary of Dumesnil, and

VOL. II. 
the immediate predecessor of Raucourt, Duchesnois, and Georges, was haunted for two years* by a ghost, who appears to have been exclusively malicious, and disturbed in his rest by disappointed love. He was a young man who had sought her acquaintance soon after her first brilliant success. She received him into intimacy, liked his society, gave him, certainly, some encouragement, relieved him from pecuniary difficulties, but refused to marry him under the most passionate and repeated entreaties. They had known each other for about two years and a half, when the ill-starred lover, finding himself on his death-bed, implored her to grant him a last interview; a request which those who surrounded her warmly seconded, but her own repugnance prevented her from complying with. He died, attended by servants, and the only friend, a female, whom he had latterly admitted to his confidence. On that same evening, as the clock struck eleven, Mademoiselle Clairon being at supper with a large party, a dreadful cry was heard by all present, which she immediately recognized as the voice of her deceased lover, and fainted with emotion and terror. For more than two years this same unearthly cry, which seemed to proceed from the empty air, was constantly heard by her wherever she happened to be at the moment, and by all who were present at the time. In vain the police established the most diligent search, thinking it might either be a trick or a conspiracy; but nothing ever transpired to shake the impression of its being a supernatural visitation. Sometimes the sharp report of a gun or pistol was substituted for the cry, accompanied by a loud and continued clapping of hands. This last demonstration reminded her of the favour of the public to which she had been so long accustomed; the effect was agreeable and consoling,

* See her Memoirs, written by herself. 
rather than productive of terror. All this went on for the time already named; and on the last occasion there was an accompaniment of melodious music, as if the ghostly visitant was taking his departure in a friendly and reconoiled state of mind.

Not long after this, an elderly lady was announced, and admitted to the presence of La Clairon, appearing before her as a perfect stranger. They sat down and gazed on each other in perfect silence, and with instinctive interest. At length the old lady explained who she was, and the object of her visit. She proved to be the friend of M. de S- - had attended him on his deathbed ; and now felt prompted by incontrollable anxiety to see the woman whose cruelty had hastened his decease. After much circumlocution, and many explanations, "Mademoiselle," said she, "I do not blame your conduct; and my poor friend fully admitted his obligations to you ; but his unhappy passion mastered his judgment, and your refusal to see him embittered, while it accelerated, his last moments. His eyes were fixed upon the clock, anxiously watching the motion of the hands, when at half-past ten his valet announced to him your positive refusal to come. After a short silence, he seized me by the arm, in a paroxysm of despair, which nearly deprived me of my senses, and exclaimed, 'Unfeeling woman! - she will gain nothing by this; I will persecute her after death, as I have followed her throughout my life!' I tried to calm him; but he died as he uttered these dreadful words."

Such is the account which Mademoiselle Clairon herself has left of this very extraordinary episode in her personal history. She states the fact, without pretending to understand or account for it; but modestly admits that she feels herself too insignificant to suppose that she could be selected as an object or medium of supernatural 
communication. Assuredly she was no accomplice in these "manifestations," which, like the more recent table-juggling, were exhibited in the presence of many witnesses.

Two light one-act pieces, "Tender Precautions," by Mr. Serle; and "Our Clerks," by Mr. Tom Taylor, were successfully produced in the early part of the season of 1851-2. The run of the latter was prematurely stopped by the secession from the Princess's of Mr. and Mrs. Keeley, who had performed the principal characters, written expressly for them, and measured to their peculiarly happy style. The Easter spectacle of "Wittikind and his Brothers," was less universally approved, and reached only twenty-one repetitions, after which it "died and made no sign." This tale of fairy magic combined much splendour of dresses and scenery, lively dialogue, and clever acting; but the plot and story were not skilfully condensed. They dragged on slowly, producing tedium, which subsequent curtailment was unable to relieve. Burlesque had passed its hey-day, and began to give evident symptoms of decrepitude.

On the 7th of June, Mr. Lovell's play of the "Trial of Love" was represented for the first time; the two principal characters by Mr. and Mrs. C. Kean. Neither the actors nor the author, on this occasion, came up to the level of the high reputation they had jointly assisted in establishing for the "Wife's Secret," to which admirable drama the present bore considerable resemblance, in the construction of plot, the time of action selected, the style of interest, and the truthfulness and grace of sentiment expressed in language of more than ordinary poetic beauty. Less than this was not to be looked for from the pen of a writer so well known and so justly appreciated as Mr. Lovell. Judged by a positive standard, the merits of the "Trial of Love" call for warm 
panegyric; but the high place in literature which the writer had attained, exposed him to a comparison with himself-a trying, though an inevitable ordeal. Tested by his own fame, it must be admitted that something was deficient. The characters appeared to be repetitions of his own fancy, reflected symbols of those he had previously created, and with which his mind had become so identified, that he drew them again without the consciousness of their being recognizable as copies of original portraits from the one hand. An objection or blemish of this nature is more strongly obvious in a play than in any other form of imaginary composition. The "Trial of Love" ran twenty-three nights, greatly to the enjoyment of successive andiences. With the exception of the "Provost of Bruges," and the "Wife's Secret," both by the same author, we cannot readily name any recent play, belonging to the same class, of superior pretensions.

On the 14th of June Mr. and Mrs. C. Kean selected the "Trial of Love" for their benefit, after which was produced a very extraordinary melo-dramatic extravaganza (by Mr. Dion Bourcicault), with as singular a designation_" The Vampire; a Phantasm, related in Three Dreams." This strange specimen of the worst possible style of French taste bore no affinity, excepting the first part of the title, to an operatic romance, by Planché, which came out at the English Opera-house in 1820, and derived its origin (through French descent) from a fragment attached to one of Lord Byron's poems, and a tale by Dr. Polidori, for some time attributed, though quite erroneously, to the noble bard himself. The whole affair, including the performance of the Vampire hero, by the English dramatizer, may be considered a mistake, of which the less that is said the better. 
The season closed on the 14 th of $\mathrm{J}_{\mathrm{uly}}$, having been much shorter in duration, and considerably more limited in remunerative success, than its immediate predecessor. For this result there were many obvious reasons, amongst which might be placed foremost the temporary reaction, very naturally to be looked for, which had succeeded the unusual excitement of the Great Exhibition. The different pieces acted amounted to exactly the same number as in the year preceding, namely twenty-seven; of which nine were new. Amongst the latter, the pantomime of "Billy Taylor" must not be forgotten, which completed its full attraction of nine consecutive weeks, and fully upheld the reputation which the house had long enjoyed in that most important branch of the art dramatic. The pantomime has ever been one of a London manager's safest cards, if played with ordinary skill. No matter how slack business may be before Christmas, he is sure to turn the tide, and "pull up" losses, through the enticement of the fare usually provided at that genial season. This same verb "to pull up," is one which managers have occasion to conjugate more frequently than they desire, and not always with corresponding success.

There is another anomalous feature attached peculiarly to the statistics of pantomime. Success lias little to do with excellence. No matter whether the subject be original or hackneyed; whether the concoction be the best or worst of its kind; or whether the thousands it must inevitably cost, be reckoned by pounds, shillings, or pence,- the length of its run, and the returns to the treasury, are pretty much the same. There is a certain sum to be got in a certain time, and no increased pressure, either in outlay, ornament, or supplementary attraction; no interpolated adjuncts, whether in the shape of acrobats, aeronauts, funambulists, elephants, horses, 
dancing dogs, or monkeys; of duplicate harlequins and columbines, multiplied clowns, and incalculable sprites, can swell that sum beyond the average amount. The case reduces itself to a matter of arithmetic. So many holiday visitors for a given number of weeks, give so much and no more.

Harlequin and his associates are not indigenous, but of exotic, continental parentage; yet they have become, with time and familiar association, so thoroughly engrafted on our island soil, that no country can compete with England in a genuine comic pantomime. The humour is not understood or relished elsewhere. The breed, too, has greatly improved with expatriation. Neither the French Pierrot, nor the Italian Scaramuccia, or Zannetto, are to be compared to our Clown; while the foreign Arlechino is little better than a clumsy, blundering buffoon. 


\section{CHAPTER III.}

MR. C. KEAX'S THIRD SEASON AT THE PRINCESS'S-THE PRIMA DONNAMELODRAMA OF MONT ST. MICHEL-ENGAGEMENT AND FIRST APPEARANCE OF MR. WRIGHT-MR. WESTLAND MARSTON'S PLAY OF ANNE BLAKE-RETIREMENT OF MR. BARTLEY-PANTOMIME OF CHERRY AND FAIR STARMR. DOUGLAS JERROLD'S COMEDY OF ST. CUPID, OR DOROTHY'S FORTUNE - REVIVAL OF MACBETH-FLY LEAF- GENERAL REMARKS ON THE PLAY AS NOW REPRESENTED-EASTER SPECTACLE OF MARCO SPADA-REVIVAL OF LORD BYRON'S SARDANAPALUS - FLY LEAF - BURLESQUES - UNFAIRNESS OF THE PRACTICE-MR. T. P. COOKE AT THE PRINOESS'SCLOSE OF THE SEASON.

Charles Kean's third campaign at the Princess's commenced on the 18th of September, 1852, with a comedy, in two acts, adapted from the French by Bourcicault, called the "Prima Donna." This new drama introduced Miss Heath, a young beginner of much promise, who made a very favourable impression; and Mr. Walter Lacy, a well-established metropolitan favourite, who succeeded to the post vacated by the departure of Mr. Wigan. The "Prima Donna" ran thirty-four nights; but, though a complete and ingeniously constructed specimen of the drawing-room class, it had scarcely weight enough to constitute the feature of an evening's performance. It was well acted, and pleased without being attractive, inaugurating the season as an agreeable prologue to the more important novelties in active preparation. Within three weeks a romantic melodrama followed, under the title of "Mont St. Michel, or, the Fairy of the Sands ;" also derived from a Frencl source, and dramatized by Mr. 
Bayle Bernard. The action is supposed to pass in Normandy in 1660, while Cardinal Mazarin exercised dictatorship in France. Every aid that beautiful scenery, punctiliously correct costume, and excellent acting could render, to carry out the ideas of the author, were lavishly bestowed; but thirteen performances wound up the affair. There was something in the arrangement of the piece that failed to stamp it with the expected longevity. It must be remembered, however, as having presented to a new constituency Mr. Wright, so long the comic atlas of the Adelphi, who had now transferred his services to a very different scene of action - the arena as distinct as if he had travelled to Edinburgh or Dublin. Every theatre in London, although it may be separated only by a street from its next neighbour, has an audience exclusive moulded to its own atmosphere. The new comer was received on his entry, as might have been expected, with long and loud applause. $\mathrm{He}$ had trod those boards before, and was a returned favourite rather than a total stranger. For an instant he appeared embarrassed, but soon recovered his selfcommand, and went to his work with the confidence of an experienced practitioner, and a merry glance of his eye, which said emphatically, "our old acquaintanceship has got a little rusty, and we scarcely recognise each other after some years' absence; but it shall be no fault of mine if we are not on intimate terms before the night is over." Harley had a part in the same piece, written up to his individual peculiarities, a pompous self-sufficient, empty-headed local magistrate of the Muddlework or Von Dunder family, who venerates the sacred institution of hanging, and would consign lis own father to the " edge of penny cord" without remorse, if it fell within the line of what he persuades himself is his duty. It was delightful to see two such actors as Harley and Wright, 
types of different histrionic ages and schools, exehanging hits in friendly contest. They resembled two cunning masters of fence, equally matched, thrusting and parrying, playing carte and tierce, without advantage on either side.

The third novelty of the season appeared on the 28th of October, in a more important shape than its immediate predecessors, - a five-act play, entitled "Anne Blake," from the pen of Mr. Westland Marston, the author of "Strathmore," the "Patrician's Daughter," and "Marie de Meranie," a writer who has placed his name, as a modern dramatist, in the front rank with Sheridan Knowles, Bulwer, and Douglas Jerrold. His earlier triumphs had proved that he was gifted with poetical imagination and clear judgment. He had shown himself a master of pathos and a genuine pupil of nature. There was nothing in the title of the present play to forestall attention, or shadow forth startling effects ; no promise of agonising incidents or a harrowing eatastrophe. It eould neither be historical nor romantic. No elue was indicated by which to guess on what the interest might turn, how the story would unravel itself, what passions would be called into action, and by what process the author intended to work out a moral or a conclusion. He must have thought with Juliet-" What's in a name?" when he seleeted one so simple and inexplicable. All this spoke of the self-relianee of genius, which scorns a flourish of trumpets, and relies on its own inherent strength.

In the eonstruction of his play (which has been printed), Mr. W. Marston appears to have taken simplicity in power to be a great seeret of dramatie effeet. This is one of the points which marks the mastery of Shakespeare over all other dramatic writers. The ineidents in "Anne Blake" are small in themselves, but 
they expand under skilful treatment. All that they comprise might happen to any one to-morrow in the ordinary occurrences of life ; and, although a happy issue falls less surely within the category of human events, it here occurs without the appearance of studied design, and is not forcibly dragged in, as Alexander by mere strength severed the Gordian knot, which he was unable by ingenuity to disentangle. The character of the heroine is well suited to call forth the powers of a great actress. Nothing could exceed the truth and beauty of Mrs. C. Kean's performance. Such a part is the more difficult to embody, in proportion as it appears easy. It abounds in fine touches and delicate pencillings, which require the most skilful discrimination, the most refined taste, to bring out with due effect. The author has portrayed a being, naturally kind and sensitive, warped by harsh treatment into fretfulness, caprice, and suspicion, until, with no inherent fault, she is on the brink of fatal error. But the warm heart bubbles up under the imposed surface, and the true principles vindicate their superiority when circumstances give them play. Colonel Thorold is a fine, manly, open-hearted soldicr, clear and consistent in thought and action, a just type of a noble class which affords many living exemplars. A man of truth in word and deed; the moral and the executive happily combined, and forming together a character more developed by strength of intellect than oratorical display. All this Mrr. C. Kean embodied with the distinctive identity which forms one of his peculiar attributes. When the fourth act terminated with the finest scene of the play, in which Thorold relates to Anne the story of her parents, and the ties which bound him so closely to her father, there was scarcely a dry eye in the house. Intense attention was only interrupted by suppressed sobs, and when the audience had time to recover, their satisfaction 
was expressed in a loud and simultaneous call for the two great performers who had so pleased by paining them. A spontaneous compliment which we believe to be without precedent on the English stage. This was repeated with equal fervour as the curtain fell in the fifth act, when the author was also demanded, according to modern custom, and bowed his acknowledgments from a private box.

"Anne Blake" was performed for forty-two nights, but many of the houses were not remunerative. Here was a play, of a high order, beautifully written, admirably acted, and perfect in all the details of scenic decoration and appointment. Successive audiences evinced their delight by what may be considered the most unerring evidences-mingled tears and applause; while the press was unanimous in eulogy. How then is it to be accounted for that the attraction should fall so far below the expectations justly excited? The question resolves itself into one of those unaccountable paradoxes apparently inherent in all matters connected with the drama, and which neither reasoning nor experience can reduce to a satisfactory conclusion. A manager naturally repeats a good play wlich gives satisfaction as long as his treasury tells him there is a chance of return; but the experiment must have a limit. In the olden time, it was not unusual to force down an indifferent or even a bad novelty until it became productive by mere dint of repetition. But the cause and the consequence have both become obsolete in modern practice.

On Saturday, the 18th of December, the veteran George Bartley took his leave of the stage in a farewell benefit, announced under the immediate patronage of her Majesty and his Royal Highness Prince Albert; that night being the fiftieth anniversary of his appearance in London. After sustaining one of his favourite 
characters, Falstaff, in the first part of "Henry the Fourth," he addressed a crowded audience in a short farewell speech, frequently interrupted by loud applause.

Bartley was born in Bath (1782), a city which has given many good actors to the stage. His father, a decayed merchant, had in the decline of life become box-keeper to the theatre there, which may have led the son to imbibe a taste for the dramatic art. While struggling with the vicissitudes of a strolling life, Mrs. Jordan became acquainted with and recommended him to Sheridan. On the 11th of December, 1802, he appeared at Drury Lane, as Orlando, in "As You Like It," and in 1805, was the original Count Montalbon, in Tobin's successful comedy of the "Honeymoon." For five years he remained the stock juvenile lover and principal walking gentleman; but his short stature and disposition to obesity warned him that his tenure of that line was likely to be brief. He therefore betook himself to the provinces for more general practice, and for the seven succeeding years, filled prominent positions at Glasgow, Dublin, Manchester, and Liverpool, either as lessee, acting-manager, or performer. At Birmingham, in 1814, he married his second wife, Miss Smith, a tragic actress of high repute, considered by many the successor of Mrs. Siddons. In 1815 he re-appeared at Drury Lane, as Fulstaff, and laid the foundation of his future fame. He next visited America, accompanied by his wife, and returned with an independent fortune, sufficient for people of moderate desires. Not wishing to retire into idle life, he engaged in the winter at Covent Garden, and during the summer recess at the Lyceum, occasionally delivering lectures on astronomy (written for him of course), illustrated by the then new transparent orrery. When Fawcett retired from the stage-management of Covent Garden, Bartley. suc- 
ceeded him, and retained his post through all changes of dynasty, under Charles Kemble, Laporte, Bunn, Macready, and Madame Vestris. He was fond of office, and assimilated himself readily to the views of the shifting authorities. If there was policy rather than independence in this, the most that can be said is, that he followed numerous examples, higher in rank and more expanded in ambition. At a period when he enjoyed professional happiness to a great extent, his domestic comfort was rudely broken up, by the successive deaths within a few years of his only son and daughter, followed by that of his wife, and consummated by the loss of nearly all his realised fortune, in a disastrous speculation. During the years 1848, 1849, and 1850, he was honoured by her Majesty's commands to read at Buckingham Palace, and Windsor Castle, the translations of "Antigone" and "Edipus," for which Mendellsohn had composed his immortal music. Subsequently he was selected to give lessons in elocution to his Royal Highness the Prince of Wales. On Saturday, the 17th of July, 1858, while sitting with his old friend and brother actor Mr. Charles Farley, at a performance of the Christy's Minstrels, he was suddenly seized with paralysis, and being immediately conveyed lome to his house in Woburn Square, he remained speechless from that period till he died on the following Thursday, the 22d. For a moment or two only he appeared sensible to a kind inquiry from her Majesty as to the state of his health. His remains were deposited with those of his family in the churchyard of St. Mary's, at Oxford.

Bartley maintained through life an unblemished character. The high estimation in which he was held privately, enhanced his professional reputation, perhaps beyond the rank to which lis talents entitled lim. 
He could scarcely be deemed an actor of the very firstclass. Although uniformly correct, judicious, hearty, and in earnest, with a perfect knowledge of the mechanism of his art, there was an appearance of labour, a want of that utter concealment of study, and of the rich, unaffected colouring which marked the acknowledged master-pieces of some three or four of his predecessors and contemporaries; such as Munden, Dowton, Fawcett, and William Farren. We hesitate to place him exactly in the same line, though, in many respects, an efficient substitute when called upon to fill the place of either

The Pantomine at the Princess's, for the Christmas of 1852-3, on the subject of "Cherry and Fair Star," had the usual success, and rather more than the usual run, extending to ten weeks. On Saturday, the $22 \mathrm{~d}$ of January, 1853, a new Comedy, in three acts, by the late Douglas Jerrold, entitled "St. Cupid ; or, Dorothy's Fortune," was presented for the first time in public. It had been previously recommended for her Majesty's private theatricals at Windsor, and acted by royal command at the Castle, on the preceding evening, Friday, January the 21st. Every effort had been made to establish a farourable anticipation; every possib'e care had been bestowed on the rehearsals, and the acting throughout gave the most unqualified satisfaction. The principal characters were sustained by Mrs. C. Kean, Mrs. Walter Lacy, Mr. Wright, Mr. Harley, Mr. Walter Lacy, Mr. J. Vining, and Mr. Ryder. The comedy was well received by the public, and noticed by the critics in a just and complimentary strain. It was played thirty-seven nights, but with very limited attraction (the receipts averaging considerably less than the expenditure), and is not likely ever to be asked for again. There was a superabundance of the epigrammatic 
terseness of diction, the sarcastic pungency, the sparkling flashes of humour, the originality of design, the distinctness of character, for which the brilliant writer had long been celebrated; but the one great principle of dramatic vitality-construction-was wanting. Of plot there was little, and of incident less. It was all dialogue, but the wittiest dialogue will not alone make an effective play. Without the action and situations by which they are enforced ; even the inspired lessons of Shakespeare would fall flatly upon the minds of his most devoted worshippers.

The tragedy of "Macbeth" was performed before her Majesty at Windsor Castle, on Friday the 4th of February. On Monday, the 14th of the same month, it was given to the public at the Princess's. On this occasion, Mr. C. Kean, for the first time, appended to his ordinary play bill, an additional "Fly Leaf," in which he prepared the audience for many innovations in architecture and costume, and named the authorities he had consulted. It ran thus:-

"The success which attended the production of ' King John,' in 1852, has encouraged me to attempt a second Shakespearean revival on the same scale. The very uncertain information, however, which we possess respecting the dress worn by the inhabitants of Scotland, in the eleventh century, renders any attempt to present this tragedy attired in the costume of the period a task of very great difficulty. I hope, therefore, I may not be deemed presumptuous if I intrude a few words upon the subject, and endeavour to explain upon what authorities I have based my opinions.

"In the absence of any positive information handed down to us upon this point, I have borrowed materials from those nations to whom Scotland was continually opposed in war. The continual inroads of the Norsc- 
men, and the invasion of Canute, in 1031, who, combining in his own person the sovereignty of England, Norway, and Denmark, was the most powerful monarch of his time, may have taught, at least the higher classes, the necessity of adopting the superior weapons and better defensive armour of their enemies. For these reasons I have introduced the tunic, mantle, cross gartering, and ringed byrne of the Danes and AngloSaxons, between whom it does not appear that any very material difference existed; retaining, however, the peculiarity of the striped and chequered garb, which seems to be generally admitted as belonging to the Scotch long anterior to the history of this play; together with the eagle's feather in the helmet, which, according to Gaelic tradition, was the distinguishing mark of a chieftain. Party-coloured woollens and cloths appear to have been commonly worn amongst the Celtic tribes from a very early period.

"Diodorus Siculus and Pliny, allude to this peculiarity in their account of the dress of the Belgic Gauls; Strabo, Pliny, and Xiphilin, record the dress of Boadicea, Queen of the Iceni, as being worn chequer-wise, of many colours, comprising purple, light and dark red, violet and blue.

"There is every reason to believe that the armour and weapons of the date of Macbeth were of rich workmanship. Harold Hardrada, King of Norway, is described by Snorre, as wearing, in the battle with Harold II., King of England, A. D. 1066, a blue tunic and a splendid helmet. The Norwegiaus not having expected a battle that day, are said to liave been without their coats of mail.

"This mail appears to have been composed of iron rings or bosses, sewn upon cloth or leather, like that of the Anglo-Saxons. Thorlef, a young Icelandic or Norwegian warrior, of the tenth century, is mentioned in the Eyrbiggia Saga as wearing a most beautiful dress,

VOL. II. 
and it is also said that his arms and equipments were extremely splendid.

"The seals and monuments of the early kings and nobles of Scotland, represent them as armed and attired in a style similar to their Anglo-Norman contemporaries. Meyrick, in his celebrated work on ancient armour, gives a plate of Alexander I., who commenced his reign in 1107, (only fifty years after the death of Macbeth), and there we find him wearing a hauberk, as depicted in Saxon illuminations, over a tunic of red and blue cloth.

"The Earl of Huntingdon, who succeeded Alexander, under the title of David I., is represented on horseback, in his seal, wearing a tunic to the knee, which Col. C. H. Smith (one of our most distinguished authorities, to whom I am deeply indebted on this, as on all former occasions), in his work on the ancient costume of England, describes as being party coloured. In the same volume he gives the figure of a Scotch knight of the time of Edward I., 1306, who holds a spear with a leafshaped blade. On his head he wears a small skull-cap of steel, like some of the ancient Anglo-Saxon warriors - of the eleventh century, and is habited in a surcoat of cloth, descending to the knee, very much resembling a kind of tartan. Siward, Earl of Northumberland, and his son, who, with their followers, were despatched by King Edward the Confessor, to the aid of Malcolm, were equipped in the leather suits called corium or corietum, which were introduced amongst the Saxons in the ninth century, and are described as having been worn by Earl Harold's soldiers in 1063, in his war with the Welsh. In the "Life of St. Colomba," written in Latin by Adomnan, one of his successors, in the early part of the seventh century, and translated into English by Dr. John Smith, in 1798, we are told that the monks at that time were clothed in the skins of beasts; though 
latterly they had woollen stuffs, manufactured by themselves, and linen, probably imported from the Continent. The houses were made of wicker, or wands, woven on stakes, which were afterwards plastered with clay, and even the Abbey of Iona was built of the same rude materials.

"Roderick, King of Strathclyde, is mentioned by Ducange as sleeping on a feather bed about this time; so that even in those primitive ages luxuries were known amongst the great.

"In the four centuries and a half which intervened between the death of St. Colomba and the reign of Macbeth, it is reasonable to presume that considerable improvements took place amongst the Scotch, and that the fashion of their dress and buildings was borrowed from their more civilized neighbours. Under these considerations, the architecture previous to the Norman conquest, has been adopted throughout the entire play. During the five centuries which preceded that event, the Anglo-Saxons made great advances, and erected many castles and churches of considerable importance. They excelled in iron work, and frequently ornamented their buildings with colour. On this subject I have availed myself of the valuable knowledge of George Godwin, Esq., F.S.A., of the Royal Institute of Architects, for whose suggestions I take this opportunity of acknowledging my obligations."

The attention of the public was powerfully arrested by this explanatory preface. Had such a document been put forth in the days of Garrick, it would have been more than "caviare" to the million, and scarcely less intelligible to the select few. In those days of little inquiry on such matters, no one ever thought of figuring to his mind's eye a portrait of Macbeth, in the outrard man, divested of a heavy court-suit as stiff as buckram, 
of complicated ruffles, and a ponderous wig "of Marlborough's ample fold," confined at first in a tie, but let loose to dangle about the actor's ears and shoulders when he re-entered in consternation from the murder of Duncan. Mr. Kean was anxious to impart his own earnest love of correct illustration to the audience to whom he appealed, and the "Fly-leaf" carried with it the assurance that in any historical play nothing would be introduced except under the sanction of historical authority. From that mornent the preface was looked upon as a necessary introduction to the performance, and became associated with it, as an interpretation, in the same light in which the Greek chorus elucidates the progress of the classical tragedy. The novelty was speedily copied by those who had never thought of it before, and from imitation passed on to burlesque, in the ordinary course of almost every original idea that obtains popularity and is felt to be instructive.

The system of Shakespearean restoration which Charles Kean had so triumphantly introduced in "King John," he carried, if possible, to a higher degree of perfection in "Macbeth." Encouragement increases effort. Finding his own views so warmly acknowledged by the public, he pursued them with the confidence which success naturally inspires. "Macbeth" ran for twenty weeks, at the rate of three performances per week. No physical strength could endure or render justice to the leading character under more frequent repetition. Throughout the whole of this period, the houses were literally crowded to the roof, and on many evenings hundreds were turned away who could obtain no admittance. The pit entrance was besieged at an early hour, and the old days of dramatic enthusiasm seerned to be revived. In the new arrangement of the play, the text of Shakespeare was most carefully preserved, a few occasional passages only being omitted as 
unnecessary to the action, and lengthening without elucidating the dialogue. It was deemed desirable to retain the appropriate music of Matthew Lock, which had been so happily composed for, and had been so long identified in complete harmony with the subject, that it might almost be considered as flowing from the Shakespearean fount. This introduction, as it had ever been before, was still sanctioned by general approval. Amongst the chief mechanical novelties we may enumerate the manner in which the apparition of Banquo was contrived, the entire arrangement of the witches throughout, particularly in the cauldron scene, which was most picturesquely original ; the rude grandeur of the banquet in the third act, and the imposing picture at the close.

Mrs. C. Kean had appeared in London before, as Lady. Macbeth, and with great success. Her admirable performance astonished all who had been accustomed to associate her more exclusively with the gentler heroines of the stage, and who were scarcely prepared to find the Viola, Portia, and Rosalind of Shakespeare equal to this tremendous incarnation.

As Macbeth, Charles Kean had frequently won the admiration and applause of the public during his earlier seasons at the Haymarket. We have already named this character as one of the prominent features of his attraction at that theatre during the season of 1840-1. Since that period, his style, retaining all its inherent energy, had become mellowed by experience and corrected by study and constant reflection. When the torrent of rage became necessary, he gave vent to it, as before, in an overwhelming burst; but now, another great and perhaps superior attribute presented itself with more marked peculiarity in his general mode of delivery -a power of condensed energy in repose, with an accompanying clearness of enunciation which renders 
the suppressed whisper as impressive as the loudest explosion of agony. There is a mastery of art in this which none but the most highly gifted and chosen few are able to accomplish. The latter quality is progressively derived from judgment regulated by refined taste; the former springs from the sudden inspiration of genius with the lightning-like rapidity of thought; as the old Greek painter dashed his sponge at the mouth of the horse he was delineating, and at once produced the foam which had so long baffled his imitative skill.

Nothing indicates true genius and conceptive strength more decidedly than the rare faculty of conveying intense passion without, as Shakespeare says, "tearing it to tatters, to very rags," and splitting the ears of the groundlings with intolerable, unmeaning noise. Deep, concentrated feeling is never loud; but common-place, routine imitators of acting, who feel nothing, are much given to exercise lungs in place of judgment, and to roar unmercifully when, if actually possessed by the simulated rage, nature would render them almost inarticulate. They cannot be made to understand this, and appeal from individual censure to the plaudits of the injudicious and ignorant many, by which their mistakes are too often encouraged. "Can you shout?" was a question once put by a country manager to an ambitious novice. "I rather flatter myself I can," replied the Macbeth in embryo. "Then learn to shout in the right place, and you'll do," was the comforting rejoinder. In this "right place" lies nearly all the mystery; it forms a dramatic pons asinorum as difficult to surmount as the fifth proposition of Euclid.

On one of the most triumphant repetitions of Macbeth at the Princess's, Mr. C. Kean received a compliment equally unexpected and agreeable. Mademoiselle Rachel happened to be present in a private box. He 
knew that she formed one of the audience, and played his best in consequence. When the play ended, she came round to his dressing-room for personal introduction. Her praises were poured forth with all the ardour of appreciating genius, and wound up with this enthusiastic ebullition, "Permettez qui je vous embrasse." Such a request demanded instant compliance, and the fraternal salute was most cordially exchanged between the two great artists. The incident recalls a similar one that happened when Garrick visited Paris. In a private party at the house of Mademoiselle Clairon, the Rachel of her day, he was asked to gratify the company by a specimen of his powers. He rose at once, and gave the dagger soliloquy from "Macbeth," without preparation or arrangement. The spectators were electrified, and Clairon, although unacquainted with the English language, was so excited by the expressive action and features, that she caught Garrick in her arms, and kissed him. Mrs. Garrick, who was present, and frequentiy related the story, invariably added, "All were surprised, but David and I were delighted."

The Easter spectacle for 1853, at the Princess's Theatre, consisted of a melodrama, entitled, "Marco Spada," very tastefully adapted by Mr. Palgrave Simpson, from Scribe's opera of the same name; the music by Auber being of course omitted. This piece was infinitely embellished by the introduction of a superb ball-room scene in the second act. It proved very successful, and commanded a run of forty-six nights, continued for thirty-two more after the opening of the next season.

On Easter Monday, in this year, an important change took place in theatrical government. Mr. B. Webster resigned the direction of the Haymarket, which he had held for sixteen years, and was succeeded by Mr. Buck- 
stone; the former gentleman from that time confining himself to the sole superintendence of the Adelphi. Mr. Webster's rule over the Haymarket was eminently brilliant and successful. The best authors and actors were most liberally paid, and the national drama encouraged with patriotic zeal. In 1844, he offered 500l., with contingent advantages, for a prize comedy, to be awarded by a committee, consisting of Messrs. C. Young, E. R. Moran, Henry Ottley, J. C. Searle, the Rev. Alexander Dyce, and G. P. R. James, with Charles Kemble for chairman. Nearly one hundred plays were sent in, and the palm was awarded to a comedy called "Quid pro Quo ; or, the Day of Dupes," by Mrs. Gore. This was selected simply because it was considered the best of the lot, and not from any estimate of abstract merit. It was coldly received by the public; its short dramatic life seconded but feebly the liberal intention of the manager, and brought no reimbursement to his exchequer.

On the 13th of June, Mr. and Mrs. C. Kean selected for their annual benefit Lord Byron's gorgeous tragedy of "Sardanapalus." Such a revival immediately following "Macbeth," and so totally distinct in character and historical epoch, excited public expectation to the highest pitch. The manner in which all new pieces had been produced at the Princess's invested the promise of "Sardanapalus" with unusual interest; and never within the annals of theatrical history was a promise more completely redeemed, or an expected enjoyment more thoroughly surpassed. When the curtain rose, we saw before us the restored palace of Sennacherib in embodied reality; and within a few moments the stage became filled with the court and retinue of the Assyrian monarch, who lived 2,700 years ago, as exactly re-animated-" in form and 
moving as express and admirable"-as if the sculptures in the British Museum had stepped on to the boards of the theatre by the power of a magician's talisman. We copy the fly-leaf from the bill, which, as in the preceding case of "Macbeth," embraces a programme of the spirit in which the present revival was conceived :-

"In the production of Lord Byron's tragedy of 'Sardanapalus,' I have availed myself of the wonderful discoveries made within the last few years by Layard, Botta, and others, on the site of the ancient Nineveh. It was during the latest excavations made by $\mathrm{Mr}$. Layard, in the south-east palace of the Mount of Nimroud, that our illustrious countryman arrived at the conclusion that this interesting structure was the work of the son of Esarhaddon, who was himself the son of Sennacherib, so famous in sacred history. 'Although, says Mr. Layard, 'no part of the history of this royal builder has been as yet recovered, still there is every reason to believe that this son of Esarliaddon was no other than the Sardanapalus, who, conquered by the Medes and Babylonians, under Cyaxares (B. C. 806), made one funeral pile of his palace, his wealth, and his wives.'

"To render visible to the eye, in conncxion with Lord Byron's drama, the costume, architecture, and domestic manners of the ancient Assyrian people, verified by the bas-reliefs, which, after having been buried for nearly 3,000 years, have in our own day been brought to light, was an object that might well inspire the enthusiasm of one who has learnt that scenic illustration, if it have the weight of authority, may adorn and add dignity to the noblest works of genius.

"I have humbly endeavoured to convey to the stage 
an accurate portraiture and a living picture of an age long since past away, but once as famous as our own country for its civilization and power, and more intimately associated with the destructive wars of the Jewish race than any other people. No pains have been spared to present to the eye the gorgeous and striking scenery that has been so unexpectedly dug from the very bowels of the earth. The sculptures now in the British Museum have been rigidly followed; and when recent discovery has failed to give authority for minor detail, I have, wherever it has been possible, borrowed designs from surrounding nations flourishing at the same epoch. In decoration of every kind, whether scenic or otherwise, I have diligently sought for truth; and it is with some pride and satisfaction I am enabled to announce that a verdict of approval has been received from the judge (Mr. Layard) most competent to speak with decision upon the surpassingly interesting subject with which I have had to deal.

"It is hardly necessary to remind the reader, that Assyria and the country beyond the two rivers, the Tigris and the Euphrates, constituted, if not actually the cradle of mankind, at all events the theatre on which the descendants of Noah performed their first conspicuous part. 'The plains of Shinar witnessed not only the defeat of that presumptuous enterprise which scattered them abroad upon the face of the earth, but also the exploits of the 'mighty hunter,' and the triumph of his ambition, in the establishment of the first monarchy recorded either by sacred or profane writers.

" More than 2,000 years' (says a modern writer, in recording the marvellous results of French and English discovery on the Assyrian plains) 'had Nineveh lain in its unknown grave, when a wandering English scholar, and a French savant, urged by a noble inspiration, 
sought the seat of the once powerful empire, and searching until they found the dead city, threw off its shroud of sand and ruin, and revealed once more to an astonished and curious world, the temples, the palaces, and the idols, the representations of war, and the triumphs of peaceful art, of the ancient Assyrians. The Nineveh of Scripture-the Nineveh of the oldest historians - the Nineveh, twin sister of Babylon, glorying in a civilization of pomp and power, all traces of which were believed to be gone--the Nineveh in which the captive tribes of Israel had laboured and wept, was, after a sleep of twenty centuries, again brought to light. The long lost was found-the dead palaces were exhumed-the strange, huge sculptures were dug out, and their inscriptions were deciphered. The proofs of ancient splendour were again beheld by living eyes; and by the skill of the draughtsman and the pen of the antiquarian travellers, made known to the world. Patience and industry rescued from the earth these treasures of a long gone people, giving proof of a great civilization existing in the earliest stages of the history of the human race.'

"It is a noteworthy fact, that, until the present moment, it has been impossible to render Lord Byron's tragedy of 'Sardanapalus' upon the stage with proper dramatic effect, because, until now we have known nothing of Assyrian architecture and costume. It is also deserving of remark, that, interesting as the bas-reliefs which have furnished such information are, they could not find dramatic illustration but for the existence of the only tragedy that has reference to the period of which they treat. I consider myself fortunate in having been permitted to link together the momentous discoveries of one renowned Englishman with the poetic labours of another. "Lord Byron having closely followed the history of 
Sardanapalus, as given by Diodorus Siculus, who has erroneously placed the site of the ancient Nineveh on the banks of the Euphrates, I have ventured to alter the text where this mistake is made, and have given the city its proper position on the river Tigris."

The late discoveries on the banks of the far-famed river having created for Assyria and its capital an unexpected interest, Charles Kean, prompted by a truly classical mind, and an inborn love of historical illustration, seized upon the opportunity that presented itself, while yet the newly imported relics were a topic of general conversation, with the tact of a skilful general and the taste of an accomplished artist. The subject and the time fortuitously harmonized. "Sardanapalus" had been acted at Drury Lane in 1834, under the management of Mr. Bunn, on which occasion Macready personated the effeminate monarch. It was not one of his happy assumptions. With the exception of the dream in the fourth act, his powers appeared to slumber through an uncongenial part. There was some correspondence as to the heroine being supported by Mrs. Mardyn, a very beautiful woman, who had long retired from the stage, but had never risen beyond an actress of moderate ability even when in her prime. Her name, in earlier days, had been, in something of a questionable shape, mixed up with that of the noble author, and it was said that she had supplied the model from which he drew his fair Ionian slave. But the report of her re-appearance subsided into air, while the play itself made little impression, and was withdrawn after a few unprofitable repetitions. The time for its successful production had not arrived. The coming disinterment of Nineveh within the next twenty years had cast no shadows before, neither were the wonderful sculptures of 
the British Museum, the aceumulated treasures of individual enterprise and sagacity, yet gazed upon by daily myriads. Lord Byron declared repeatedly, in conversation, in letters, and in print, that his tragedies were not composed with the most remote view to the stagethat they were neither intended for, nor suited to, representation; and exclaimed loudly against Elliston's immolation of "Marino Faliero." He even applied for an injunction to restrain future attempts, but without success. Having served on the committee of Drury Lane, he was well acquainted with the maragers and actors of his day. He had no great opinion either of their taste or discrimination, disliked to be fettered by their eaprices, and, above all, dreaded the ordeal of a mixed audience. He may have been sincere to a certain extent; but we suspect there was both fencing and coquetry in some part of his objections. Why did he write in the dramatic form, if he repudiated the legitimate exereise of that style of composition? The essential and characteristic ingredient of a play is action - "Something," as Jeffrey says in the Edinburgh Review, "supposed to pass before the eyes of the assembled spectators." We have known many dramatic authors, but we never yet encountered one who considered it a compliment to be told that his play was more fit for the closet than the stage-that it read better than it would act. He is almost as well pleased with the qualifying distinction as an actor is when an influential eritic calls his performance of a pet part, respectable. That a play should be written for the express purpose of not being acter, sounds very like a predetermined contradiction. It seems almost as inconceivable as that a dinner should be cooked not to be eaten - a song composed not to be sung-a book printed not to be read-a coat made not to be worn-or a house 
built not to be inhabited. Had Lord Byron lived to see "Sardanapalus" placed on the stage as it was at the Princess's Theatre, he would have altered his opinion, and must have admitted, from proved experiment, that his tragedy contains all the leading elements of dramatic success-action, dialogue, incident, interest, and catastrophe; not forgetting what he himself calls the "law of literature throughout the more civilized parts of the world," and still fondly cherished by a few rigidly classical enthusiasts-a strict observance of the Aristotelean unities. He would have been taught, too, that the tribunal he so earnestly prayed deliverance from, is never slow to acknowledge the supremacy of genius, when clothed in appropriate garb, and attended by its indispensable auxiliaries.

In spite of all that exploded bigotry and prejudice have attempted to set forth to the contrary, the stage, as it presents a combination of the ornamental arts, will ever, when properly administered, be considered the most improving as well as the most intellectual of civilized recreations. We see there placed before us, in actual existence, the animated reality of what we can otherwise only become acquainted with through the cold medium of description. The genius of the poet, aided by the executive talent of the actor, recalls the buried ages of the past, and brings them in review before us with a living reality which mere reading or relation could never impart. We think profitably, and acquire useful lessons in the study, but we live over again in the theatre. "The drama," as Lord Bacon justly observes, "is as a history brought before the eyes; it exhibits the image of things as if they were present, while history treats of them as entirely extinct." Plato wished that virtue could assume a visible form. Dramatic representation gives one both to virtue and to vice. It sets 
forth models for admiration and abhorrence; and as example is better than precept, the moral thus presented affords the benefit of both at once.

Many who had taught themselves to believe, or had been drilled into a conviction, that the modern stage is in a state of decline, and that we live under the lower empire of theatrical taste, began to dismiss their preconceived notions, and to repent of a long-cherished heresy, as they witnessed and felt the gradual effect of these unprecedented revivals. Where one person formerly enjoyed the lights of knowledge, and admitted the impulses of refinement, a thousand now possess the advantages which were denied to their grandfathers. But this general advance of education has added new difficulties to the dramatic art. The appetite of the public is much more craving and more difficult to satisfy than it was fifty or even twenty years ago. 'The present age is eminently pictorial, and in the embellishment of a play, the most costly accessories are now indispensable which formerly were never required. Errors or deficiencies of costume and general decoration, which in the days of Garrick and under the management of the Kembles were passed without notice, are now watched and scrutinized with the most jealous eriticism. The very cavillers who cry out upon superabundant ornament, would be the first to carp and exclaim if that salient object of their censure should either be modified or withdrawn.

"Sardanapalus," as revived by Charles Kean, comprised a subject for reflective study, from which the most careless spectator might derive profitable information and cnnobling thoughts. His own performance of the last descendant of Semiramis was marked by the truth, energy, and variety whic! $1_{1}$ distinguish his ablest conceptions. The Assyrian monarch is a sanguine voluptuary, without being coustitutionally unfeeling or 
effeminate ; a royal sensualist, who enjoys life while he dallies with death; who rushes from the banquet-table to the battle-field with the careless gaiety of a disciple of Epicurus, and rises into a hero under the pressure of circumstances, without effort or parade. The terrible grandeur of his self-sacrifice would be incredible, nay, almost unnatural, did we not believe it to be true. In sociable qualities, and in good temper, he bears a striking resemblance to our own Charles II., while he soars far beyond him in inherent magnanimity. We feel interested in lis fate from the beginning; he retains our sympathy to the end, and we mourn sincerely over his fall. We almost forgive his inconstancy to his Queen for the touching kindness and self-reproaches of their parting interview.

Myrrha, the Ionian captive, is a beautiful introduction, forming the chief charm and relieving feature of the drama. Utterly unselfish, and devoted to the King from personal affection, she uses her influence over him for the most ennobling purposes, appearing more like a guardian genius than an earthly lover, striving to win him from lis fatal course, while she soothes and adorns its appalling close. 'The feminine softness and devotion of the character, so heroically blended with Grecian pride and courage, were portrayed by Mrs. C. Kean with all her accustomed taste and nice discrimination. Miss Heath enacted the single scene, in which the Queen Zarina appears, with dignity and feeling. Some frigid critics have condemned this affecting episode as unnecessary and inappropriate. In our humble judgment we think it as opposite to both as language can express; and if the excited feelings of an audicnce are to be admitted as evidence on the question, we can appeal to them strongly in support of the impression produced. The stern soldier, but faithful friend and subject, 
Salemenes, stood prominently forth in the hands of Mr. Ryder, and formed throughout an admirable contrast to the amiable thoughtlessness of Sardanapalus. Lord Byron himself imagined that the character of his regal hero approached the comic; a strange fantasy, for which we profess ourselves unable to discover the slightest foundation.

In the acting version of this noble drama all the subordinate parts were filled by careful and judicious representatives. Every line was distinctly and characteristically uttered. The curtailments necessary to bring the play, as originally written, within reasonable acting length, tended greatly to increase and condense its dramatic force. It is difficult to make selections from a whole so skilfully blended together; but we may name three leading effects, as surpassing in truthful display anything we had ever until then seen attempted on the stage:-the procession which introduced the entry of Sardanapalus, in the first act; the banquet and dance in the hall of Nimrod in the third; and the conflagration of the palace and city, which closed the fifth.

Those of our readers who are acquainted with the mechanism of a theatre will readily understand that the last wonderful exhibition was produced more by artificial means, than through the agency of real fire-an element too dangerous to employ to any extent. Many of the audience, however, sat in mingled admiration and terror. On the first night, an old half-pay colonel, in the stalls, was overheard by his neighbour saying to himself, "Oh! hang it! this is too much. Kean is going beyond the mark this time-he will certainly burn the theatre down." He then looked round to observe the effect on the assembled house, and continued-" Therell be a rush to the doors in a moment, and lives may be lost; 
but I shall keep my seat, come what may, until they are all out."

The insurance companies took the alarm, and sent their officers to make a strict investigation. The mystery was explained to them, and on the next night they were posted in a convenient corner of the stage, from whence they could witness the entire operation. But when the flames burst forth, the pile began to sink, and what appeared to be blazing rafters and showers of fire descended from the roof of the palace, they made a precipitate retreat, exclaiming that they were perfectly satisfied.

The unusual attraction of the Assyrian tragedy stimulated a corresponding amount of the never-wanting ridicule which dogs the steps of successful management, according to the received London practice. Such opportunities are tempting, and not likely to be passed over, as long as the public encourage what it would be better taste to condemn. Shakespeare's "Macbeth" and "Merchant of Venice" had been very recently degraded to travesty; why then should Lord Byron be spared? Two burlesques on "Sardanapalus" appeared within a week of each other, at different theatres, whilst the original, at the Princess's, was in the first glow of its attraction. The "Fly-leaf," again, was considered too good to escape, and furnished food for more extensive parody.

If there be any truth in spirit-rapping, and the dead are really cognizant of, and take an interest in the everyday occurrences of the life they have left, we wish some specially-gifted medium would charm up Lord Byron, and inquire of him how he feels as to the stage treatment of his dramatic works. To the last hour of his existence, he protested against their being acted. Even of "Werner," he said in the preface, "The whole is neither intended, nor in any shape adapted, for the stage." 
We wish it were possible to ask him, for what eoneeivable reason a professed author dramatizes a popular novel, unless with a conviction of its fitness for representation.

A highly successful season at the Prineess's terminated with the sixty-first representation of Lord Byron's tragedy; which, on the re-opening in the following. October, was again resumed, and continued for thirtytwo additional nights. During the season which ended on the $2 d$ September, 1853, the "Corsican Brothers" commanded fifty-five full houses. The only light novelty produced was a piece, in one act, entitled, "Chesterfield Thinskin" (an adaptation from the French, by Mr. Maddox), which came out in the beginning of August, and ran to the last night. The total number of pieces acted, during a season of rather more than eleven months, amounted to thirty. Of these, seven only, including the pantomime, were entirely new. Three old farces, the "Spitalfields Weaver," "Bombastes," and "Deaf as a Post," were revived for Mr. Wright, who seceded from the company when the season ended. "Black-eyed Susan" was played during a three-weeks' engagement of 'T. P. Cooke, before Christmas. We rejoice to see that this the truest representative of the British tar of Nelson's day, who ever stepped from the quarter-deek to the boards, is still rated on the theatrical books, and has lately daneed his inimitable hornpipe, with as much vigour as he displayed when we first had the pleasure of his acquaintance-more years ago than we feel disposed to chronicle. Without envying him his activity, we sineerely wish we were able to emulate it. 


\section{CHAPTER IV.}

CORRESPONDENCE BETWEEN MR. CHARLES KEAN AND MR. DOUGLAS JERROLD - MR. BLANCHARD JERROLD'S STATEMENT IN HIS FATHER'S LIFE-REASONS FOR PUBLISHING THE LETTERS-THEIR TENDENOY AND RESULTINCIDENTAL OBSERVATIONS.

During the year 1853, from April to October, an interchange of letters took place between Mr. Charles Kean and the late Mr. Douglas Jerrold, entirely confined to certain dramatic arrangements pending between them, and as yet imperfectly carried out. It was not intended, in the present biography, to refer to this correspondence, or to the permanent hostility thereby engendered in Mr. Jerrold's mind towards Mr. Kean in his double capacity as manager and actor. The matter had been forgotten by the public; Mr. Douglas Jerrold was dead; and Mr. Kean would never have permitted any allusion to, or revival of the ungracious subject, had not Mr. Blanchard Jerrold so unnecessarily (shall we add, imprudently and indelicately?) raked $\mathrm{np}$ its ashes in his recent life of his father. In that work he has thought proper to republish a most virulent article from Lloyd's Weekly Newspaper of October the 15th, 1854, on the production of the "Heart of Gold."

We step a little onward in the order of time, to insert the article here, as necessary to a clear understanding of what follows:-

"A HEART OF GOLD" AT THE PRINCESS'S.

"For obvious reasons, 'A Heart of Gold' is not a subject for criticism in this journal. A few facts, how- 
ever, may be given by the author in this his farewell to all dramatic doings. The piece was written some four years since, at the solicitation of Mr. Charles Kean, and duly paid for. The hero and heroine were to be acted by himself and Mrs. Charles Kean. They were, in fact, written to be so acted.

"Subsequently, however, Mr. Kean's tragic elaims were questioned in a wicked publication called Punch: and the actor himself graphically rendered in certain of his many moods of dramatic inspiration. Whereupon, Mrr. Charles Kean broke his compact with the author of 'A Heart of Gold;' he would not play his hero, but find a substitute. A new cast of characters was proposed, against which the author gave his written protest. But Mr. Charles Kean had, in 1850, bought the drama; aud, therefore, in his own mercantile way, conceived that in 1854 he had a right to do what he liked with his own black-and-white 'nigger.' The author thought differently, and stood to his protest. Despite of which, however, on the close of last season, Mr. Charles Kean's solicitor informed the author's solicitor (there is parchment on Parnassus!) that ' $\mathrm{A}$ Heart of Gold' would be produced at the commencement of the present season. To this no answer was made. The author had once protested, and that he thought sufficient to Mr. Kean and to himself. Nevertheless, the piece was put into rehearsal; and yet the author had no notice of the fact. Perhaps Mr. Kean thought the author might spontaneously send his solicitor to superintend the rehearsals, who, with Mr. Kean's solicitor, would settle writs of error as to readings, misconceptions, and so forth. Had the author done so, even under such professional revision, there had doubtless been fewer misdemeanours against nature, good taste, and propriety. 
"Yet it is under such wilful injuries committed by a management that a drama is, nevertheless, to be buoyant! It is through such a fog of player's brain that the intention of the author is to shine clearly forth. With a certain graceful exception, there never was so much bad acting as in 'A Heart of Gold.' Nevertheless-according to the various printed reports-the piece asserted its vitality, though drugged and stabbed, and hit about the head, as only some players can hit a play-hard and remorselessly.

"In a word, against the author's protest of misrepresentation, was his play flung, huddled upon the stage; without a single stage revision allowed on his part. Solicitors have been alluded to, but it should be stated, legal interference was first employed by the author for his self-security. He would have no written or personal communication with an individual who had violated the confidence of honourable minds by printing ' for private circulation only' private letters; letters that-had the writer's consent been, as is usual in such cases, demanded-might, for him, have been posted in market-places. It was in consequence of this meanness, that the author, in subseqnent correspondence, employed a solicitor. For, in the writer's mind, it requires a very nice casuistry to discover the difference between picking the confidence of a private letter and picking a lock. To be sure, there is this difference in the penalties: in one case we employ a policeman-in the other contempt."

The above notice, Mr. Blancliard Jerrold duly verifies as coming from the pen of his father, and endorses it with his own opinion in the following words:-

"This farewell was written in the most natural bitter- 
ness of spirit, and it is only because $I$ know it to be just, that I print it."

Here is a direct challenge, and silence now would assuredly be misconstrued into an admission of weakness. Under a combined battery of detraction and ridicule, poured upon him for many successive months in two widely circulated papers, Mr. Kean remained perfectly passive. Many of his friends wondered at this, and urged him to reply. But he was too good a general to commit such an error, and too prudent to engage an enemy on his own ground with his own weapons. He would not give that enemy the triumph of seeing him wince; and experience had taught him that a public man gains nothing by impatience under attack. He had neither time nor inclination for newspaper controversy. He felt that he had a great majority on his side, and was satisfied with that conviction. He knew, moreover, that the public take little interest in personal disputes, beyond the momentary excitement and pleasure of a squabble of any kind, with the hope and expectation of its winding up, after the usual mode, with the club logic of the worthy sergeant in "Tom Jones." "Craving your pardon, Sir," says Partridge, "that's a non sequitur." "You're another, if you come to that," retorts the sergeant ; " and I'll fight any man for a crown."

That Mr. Kean did circulate amongst his friends the correspondence between Mr. Douglas Jerrold and himself, is as certain as that he had just causc for so doing. The immediate provocation was a notice of "Faust and Marguerite," that appeared in Punch of the 6th of May, 1854 ; and was copied into Lloyd's of the 7th. This article, being too long for insertion here, is included in the Appendix (A). We refer to it as an exemplar of the series, and as a literary curiosity, showing how 
weakly a clever man can write when he suffers rational criticism to be superseded by personal acrimony.

Mr. Kean was driven to the course he adopted, in selfdefence, to explain what was otherwise an unintelligible mystery, and to let the truth be known to his own circle, as it actually occurred. Such critical notices as those indited by Mr. Douglas Jerrold manifestly defeat themselves; but, although the animus which dictates them may be transparent, many are inclined to ask, "Why is this so? and what can Mr. Kean have done to provoke such pertinacious hostility?" Perhaps a solution lies in the subjoined correspondence.

There is not a syllable in these letters intended or implied, in the most remote degree, by either writer, to be of a private or confidential nature. They treat as exclusively of matters of business, as the negotiation by which a house is leased, or an interchange of property effected between contracting parties. They are as available for evidence, in case of litigation, as a bill of sale or an attested account. No sophistry can subject them to any other interpretation. The attempt is ridiculous. If a common jury, or a special court of honour, could be assembled to consider such a charge, they would throw it out in scorn without a moment's deliberation.

When the relations and friends of Mr. Douglas Jerrold, with a natural bias by which we are all more or less influenced, seek to represent him as a man of philanthropic soul and kindly sympathies, of benevolent heart and social affections, of brilliant wit, playful but unwounding, of vast conversational powers and unlimited scope of intellect, of gentle temper and happy disposition,-it falls not within the province of a stranger to dispute the fidelity of the picture. But when, to complete this eulogium, facts and inferences are assumed, injurious to the character of another, jus- 
tice casts aside reserve, and demands truth. The dealings of public men, in their professional capacities, are extensively canvassed and claimed as legitimate subjects of discussion. Conclusions are often drawn from very imperfect information. If, in the present case, on a full statement, public opinion should be less favourable to his father's memory than Mr. Blanchard Jerrold may desire or anticipate, he must remember that he alone has evoked the subject, and has no one but himself to blame for the result.

The writer of these pages, in speaking freely here and in other places, of Mr. Kean's thoughts and opinions with regard to the transactions referred to, begs to have it understood explicitly that he was, and had been for many years, in daily, he may say in hourly communication with him. He knew every turn of his mind, and reflected the impression of his feelings almost as faithfully as lie retained them himself.

The "Correspondence" with Mr. Jerrold will tell its own story; but a few preliminary observations are necessary, to render the questions it involves sufficiently intelligible. Two three-act dramas had been purchased by Mr. Kean from Mr. Jerrold, in 1851 ; - the "Heart of Gold," and "St. Cupid; or, Dorothy's Fortune." For each of these, $300 l$, the sum agreed on, had been paid to the author on delivery of the respective manuscripts. It was intended that the first should take its due precedence in representation; but it was mutually agreed, in consequence of incidental cireumstances, that the order of acting should be inverted, and the second supersede the first. In the meantime (in April, 185े2), Mr. Jerrold proposed to Mr. Kean a treaty for a third drama. This Mr. Kean was unwilling to enter into, having already two in hand, paid for but not acted. In the course of the conversation, $\mathrm{Mr}$. Jerrold stated that 
he was urgently in want of money, upon which $\mathrm{Mr}$. Kean at once adopted his views, and advanced him $100 l$. on account of the suggested play. This sum Mr. Jerrold afterwards considered as a loan, and repaid with the accruing interest on the 28th of April, 1853.

It has been seen that the comedy of "St. Cupid,' having been previously played at Windsor Castle by selection of her Majesty, was produced at the Princess's in January, 1853. It was well received and frequently repeated, but, as a commercial venture, the manager found himself out of pocket to a large amount, without including the purchase money. Early in the year preceding, 1852, Mr. Douglas Jerrold, in addition to his literary connexion with Punch, had become the avowed editor of Lloyd's Weekly Newspaper, one of the most extensively circulated publications of the class in the metropolis. That paper had always, in its theatrical criticisms, expressed the most flattering opinions of $\mathrm{Mr}$. C. Kean in his professional capacity; and the friendly spirit suffered no change under the new editorship until the progress of the correspondence now to be produced. Nothing could be more complimentary than the articles on the "Trial of Love," "Anne Blake," and other less important novelties. Of "Macbeth" we find this notice, on the 20th of February, 1853 :-

"“Macbeth', played at the Princess's on Monday night, is a marvellous triumph of scenic and mechanic art. We shall not attempt to describe all its glories, all its scenic effects. We would as soon endeavour with pen and ink to paint a rainbow on our paper, or to give the glowing colours of a cameleon. Suffice it, that it is a magnificent triumph for the management, and will reward Mr. C. Kean with golden opinions, and-what he may think quite as good-golden assets." 
Of Sardanapalus, in the paper of the 12 th of June, a more elaborate panegyric runs thus:-

"That one performance gave us a better insight into the manners and habits of the Assyrians, than a whole lifetime has enabled us to acquire of the French. It was a grand lesson of animated geography; and the more curious, as being the animated geography of a nation that is dead. Mr. Charles Kean has been the noble teacher on this occasion, and he cannot be praised too highly for the generous spirit in which he has carried out and illustrated his pleasant teaching. He has done his work like a magician. With his managerial rod he has made Nineveh spring out of the pages of Mr. Layard's monumental book, and to become endowed with all the awe and grandeur of the living thing. He has built a new empire upon the stage; the result is something to remember for life. We have never seen anything so perfect on the modern stage, and it certainly is a great honour to the theatre that has produced it; an honour that has not only. been honourably gained by the prodigality that has been showered, as profusely as the golden shower of fire in the last scene, upon its production, but likewise by the refined taste that, aided by Mr. Layard, has presided over it. Two great qualities manifest themselves throughout - the feeling of a poet, and the pocket of a prince; and we need not say how rarely it is that you meet with either the one or the other, much less a combination of the two, in a manager now-a-days. To finish, it is a joy to us to confess that, for many years to come, 'Sardanapalus ' will be a beautiful picture to hang up in the long, dreary halls of our dramatic recollections; a beautiful picture we shall always be able to look back to with increased pleasure." 
Those who are curious in such matters, if they turn over the pages of Punch of about the same period, or a little later, will find this identical picture grossly caricatured by the same hand, which may supply them with materials for profitable meditation; and in Lloyd's of September the 11th, 1853, the earlier opinion of "Macbeth" assumes an altered tone, difficult to understand without a clue :-

"Macbeth has been reproduced at Sadler's Wells, with all the original effects of 1847 . These are the same effects which Mr. C. Kean made such liberal use of last season, for his version at the Princess's. They are in every respect as effective as the latter, and have the still further merit of being produced the first."

In a subsequent article, on the 6th of November, we find this general summary:- "Play-going at the Princess's is sight-seeing, and nothing more; and a visit is invariably accompanied by the ennui that accompanies sight-seeing." The current in Lloyd's Weelcly Newspaper began to turn into the hostile channel after the notice on Sardanapalus in June, and very speedily settled down into unmitigated invective. The squibs and caricatures in Punch had taken long precedence; but as Punch lashes everybody and everything, Charles Kean had, at least, the satisfaction there of being ridiculed in good company.

A notice of Mr. Blanchard Jerrold's book, in John Bull, of February 26tl, 1859, says: "The abuse of Mr. Kean (in Punch) was marked (if we are not mistaken) by a character of malevolence quite alien from the ordinary tone of dramatic censure. In fact, Mr. Jerrold's attacks on Mr. Kean had commenced long before this, when the former was a contributor to the 
Morning Herald, and the latter was just rising into fame as an actor of mark. They commenced, too, immediately after a play of Jerrold's had been declined at the Haymarket Theatre, in consequence, as he conjectured, of Mr. Kean's repugnance to undertaking one of the characters in it."

Having now cleared the way by explanatory notes, we proceed to introduce the correspondence :-

"To Douglas Jerrold, Esq.

" 3, Torrington Square,

“26th April, 1853.

"My dear Mr. Jerrold,-

"I have been expecting, according to your promise, to hear from you respecting the Nautical Drama we talked about. It is now nearly twelve months since I advanced you 100l. in anticipation of a new piece, and I am naturally anxious to ascertain that something is in progress. I wish the drama to be in my possession before the close of the present season; and feel satisfied that the subject is one that, with the aid of your genius, will prove successful. Requesting an early reply,

"I remain, "Yours very truly, "Charles Kean."

\section{"To Charles Kean, Esq.}

"Circus Road, St. John's Wood, " 26 th April, 1853.

"My dear Mr. Kean,-

"Our arrangement for another drama had no reference to a 'Nautical' drama ; that was an after-propo-

- There is a mistake here. When Mr. Kean was acting at the Haymarket and long before he had any idea of entering on management, Mr. D. Jerrold proposed to him to purchase a play of his, called (we helieve) the "Spendthrift," which Mr. Kean declined. 
sition on your part, that I thought had wholly passed away with the late Easter. Nevertheless, our original agreement I will, at your wish, fully cancel. My thoughts have reverted to the first subject, which shall be, or shall not, as you elect,

"If you think the nautical drama available, I shall, notwithstanding, be very glad to give my notion of the, matter to a gentleman who, I believe, would do full justice to the subject.

"Yours sincerely,

"D. JERROLD."

\section{"To Douglas Jerrold, Esq.}

\section{"My dear Mr. Jerrold,-}

“27th April, 1853.

"I do not quite understand your reply tọ my note. It is perfectly true that you suggested to me a subject for a two-act drama about a twelvemonth since, when you asked for an advance of $100 l$. I immediately let you have that sum, at no small inconvenience to myself, as you stated you were at the time much pressed for money; without entering into any very detailed understanding with you respecting the piece, beyond the fact that you were to accomplish it during the theatrical vacation, which portion of your agreement, I need not remind you, was not fulfilled. Having at the time in my possession two three-act pieces from your pen, for which I had paid you the full amount, namely, $300 l$. for each, it stands to reason I did not then require a third, and was only actuated by a kindly feeling and a desire to oblige you.

"When I applied to you on the subjcet of a nautical drama, not having heard a word from you in the interim, on the original subject named, I did so, intend- 
ing this should be in lieu of the one first mentioned. You now tell me that you will either cancel the original subject, or go on with it, as I may wish; and at the same time infer that you decline writing the nautical piece.

"Handing over the subject in question, as you now propose to do, to another author, is of course not to be thought of. If I wished another to undertake the work, I could find that author myself. I wish your aid for the nautical drama, which, if carried out as we agreed upon, I feel would have much more attraction than the subject originally proposed by you. I am quite willing to avail myself of your offer, and cancel the original understanding. If you will, however, finish (as you promised to do) the nautical drama in three acts, introducing the stage effects we talked of, I will give you an additional $200 l$. to the $100 l$. you have already received. If this arrangement does not meet your views, you will oblige me by returning the $100 l$. I have advanced. Let me have your answer without delay; and believe me,

"Yours truly, "Charles Kean."

"To Charles Kean, Esq.

“ 26, Circus Road, St. John's Wood, “ 2sth April, 1853.

"My dear Mr. Kean,-

"Herewith I return you the $100 \mathrm{l}$. advanced last A pril, I think, within a day or two of the present date. Under the circumstances, and to make the matter a purely commercial one between us, you must permit me, in deference to my own self-respect, to add to the $100 \mathrm{l}$. the twelvemontl's interest, at five per cent. It is very true, that, desiring to comply with your wish, so earnestly expressed, I did waive the subject upon which you advanced the money, and consented, with no plea- 
sure to myself, for I have had enough of nautical pieces by which fortunes have been made by others, and comparatively twopence-halfpenny by your humble servant; nevertheless, I did consent to handle oakum once more for the Princess's. But this arrangement, as I have said, passed away into thin Easter air with your new Easter drama. My thoughts have since been occupied with the previous subject, However, no harm is done. I might, were it permissible to a writer, a mere writer, to complain about anything, I might, perhaps, venture a slight murmur of disappointment, that my first drama, written for your first season, remains unacted in your third. I might complain, but will be dumb as an oyster, and nevertheless

"Yours truly,

"Douglas Jerrold."

"To Douglas Jerrold, Esq.

" 3 , Torrington Square

"28th April, 1853.

“My dear Mr. Jerrold,-

"I beg to acknowledge the receipt of your eheque for $105 l$. in return for the $100 l$. I advanced you last April, the additional $5 l$. being interest for the same.

"Of course I have no answer to make to your remarks concerning 'the fortunes that have been made by others and the comparatively twopence-halfpenny by you,' on account of your former nautical picces, beyond reminding you that my offer was $300 l$. for a drama of the kind, being the same sum you have asked and received from me, for a three-act play and a three-act comedy.

"In reply to your concluding remarks, that you might perhaps venture a slight murmur of disappointment that your first drama, written for me, had not yet 
been acted, you must permit me to remind you that you were put fully in possession by me of the unfortunate position of affairs between *** and myself; and appeared from your tone, not only to sympathise with me, but also to appreciate the motives that induced me to put it aside. Indeed, as you well knew at the time, I had no alternative.

"Afterwards, it was at your own express desire that 'St. Cupid' should be brought out first, should I be fortunate enough to have it selected for representation at Windsor Castle.

"I cannot but feel that you must have forgotten our various conversations, or you would not now urge against me a complaint which has no foundation in justice.

"I have endeavoured to do all in my power that is right and kind by you, and if I have failed in conveying that impression to your mind, I can only express my very great regret.

$$
\begin{aligned}
& \text { "Truly yours, } \\
& \text { "Charles Kean." }
\end{aligned}
$$

\section{"To Charles Kean, Esq.}

“ 26, Circus Road, St. John's Wood, “ 29th April, 1853.

"MY dear Mr. Kean.

"Pray believe me that I make no complaint whatever of the postponement of the piece during your junction with ***. It was necessary, and I felt that you were hardly placed. But, when we parted at the conclusion, or some time before the conclusion of last season, it was certainly my impression that you proposed to open the present season with the first drama. Something mocks my memory, if you did not on that 
occasion observe, - - then you'll have two pieces next season.' But let this pass. Your offer for the nautical piece is liberal; and it is by no means of your terms I should think to complain. What I mean is, the recollection of the scurvy treatment $I$ received where the largest success accrued to others, makes nautical dramas particularly repugnant to me, though I should certainly have written the piece for Easter; and for this simple reason, I had promised to do so. Your arrangements took another form.

"For myself, in this matter, I part in perfect good temper; for, as I have said, there is, I hope, no harm done.

" Yours very truly,

"Douglas Jerrold."

"To Douglas Jerrold, Esq.

" 3 , Torrington Square, " 30 th April, 1853.

"My dear Mr. Jerrold,-

"You are, so far, quite correct in stating that it was, at one time, my intention to commence the present season with your drama. Afterwards, however, when 'St. Cupid' had been selected for representation at the Court Theatricals, I suggested to you the policy of allowing that comedy to be first performed at the Princess's, as any previous production of yours in the same season might, in some degree, mar the éclat which would, under the unprecedented circumstances, probably attend ' St. Cupid.' You perfectly coincided with my opinion, and expressed your desire that 'St. Cupid' should be first performed; therefore what has been done received your sanction and approval, and you surely are not justified in the complaint you have made against me. In answer to what you state respecting 'the nautical 
drama," it is perfectly true that, when I first submitted the matter to you, it was with a view to Easter; but in an after conversation between us, while sitting together on the bench adjoining Massingham's Office, it was agreed to relinquish the original intention with regard to Easter (for various reasons which $I$ need not now enumerate), and you left me with a promise that you would write me a drama on the subject named. I was certainly impressed with the feeling that it was as much a bargain between us, as if there had existed a written contract to that effect.

"Yours truly, "Charles Kean."

\section{"To Charles Kean, Esq.}

“ 26, Circus Road, St. John's Wood, "May 17th, 1853.

"My dear Mr. Kean,-

"Will you favour me by letting me know if it be your intention to produce my play of the "Heart of Gold ' next season.

"Yours truly, "Douglas Jerrold."

“ To Douglas Jerrold, Esq.

$$
\text { " May 18th, } 1853 .
$$

"My dear Mr. Jerrold,-

"In all our business transactions I have never failed to consult your wishes, and am equally disposed to do so now. Tell me explicitly what you desire respecting the "Heart of Gold," and it shall be carried out in evcry point, if practicable.

$$
\begin{aligned}
& \text { "Yours truly, } \\
& \text { "Charles Kean." }
\end{aligned}
$$

To this letter Mr. Jerrold sent no reply. 
"To Douglas Jerrold, Esq.

" August 24th, 1853.

"Dear Sir,

"As I infer, from your late correspondence with me, that you are anxious your play of the 'Heart of Gold' should be produced without delay, I have determined, whatever may be the inconvenience to myself, to make it one of the earliest novelties of my next season.

"As we close on Friday week, 2d September, it will be necessary that the drama should be read, and the parts distributed, before that date.

"In the absence of Mr. Wright, who leaves my theatre, I purpose giving the part of Michaelmas to Mr. Harley; Mrs. Walter Lacy will play Molly Dindle; Mr. Ryder, the part of John Dymond; and the rest of the characters will be cast according to the ability of the company.

"Perhaps you will so far oblige me, as to name the day (Saturday excepted), on which you will read the piece.

"I remain, yours faithfully,

"Charles Kean."

"To Charles Kean, Esq.

“ 26, Circus Road, St. John's Wood, "August 25th.

"Dear Sir,-

"Probably I may be enabled to relieve you of my drama of the 'Heart of Gold.' To the cast you propose I cannot consent. In the event of finding another theatre, are you disposed, the money being repaid, to return the drama to

"Yours faithfully,

"D. JERROLD." 
"To Duuglas Jerrold, Esq.

“25th August, 1853.

"Dear Sir,-

"I will meet your wishes, and immediately return the play of the 'Heart of Gold,' if you will refund the $300 l$. I have paid you for it.

"I do so under the conviction that no good can accrue to any party concerned in its production at my theatre, where a hostile and malicious feeling exists, on the part of the author, towards the person and management of the man to whom it is entrusted.*

"As I quit London on the 3d September, perhaps you will be good enough to acquaint me with your determination respecting the re-purchase before that date.

"Yours faithfully,

"Charles Kean."

"To Charles Kean, Esq.

"August 30th.

"Dear Sir,-

"I do not return to London until the end of September. I will then, should I find my drama available elsewhere, of which $I$ have little doubt, repurchase it of you. Of course, you cannot forget that you applied to me to write the piece. I never sought you; the parts were written for Mrs. Kean and yourself, and accepted with much laudation. After three seasons you propose a most damaging alteration of cast, and break your compact. Be it so.

"And now, dear Sir, as to "the hostile and malicious feeling' you attribute to me as regards your 'person

* This is in reference to the repeated attacks made upon Mr. C. Kean in Lloyd's Weekly Neuspaper and Punch. They must be read to convey an understanding of their full virulence. 
and management,' I can believe that your habits may not enable you to perceive the ill manners and the injustice of such an unsupported imputation. Neither hostility nor malice exist in me towards you or your doings. You would probably think it very rude in me were I, because you have broken faith with me, to stigmatize you as a person vain, capricious, unstable in his agreements, with a festering anxiety to consider every man his mortal enemy, who is not prepared to acknowledge him the eighth wonder of the habitable world.

"I feel almost certain that you would think this very rude in me. Therefore, be more chary of your imputations of malice and hostility towards

"Yours faithfully,

"Douglas Jerrold."

\section{"To Douglas Jerrold, Esq.}

"Dear Sir,-

"August 31st, 1853.

"I wish to pass over that portion of your letter (received this morning) intended to be offensive, and confine myself to saying that, throughout our transactions, I have acted towards you with all the kindness, liberality, and consideration in my power, which I fear your unfortunate nature is not capable of appreciating.

"Your personalities do not in the least surprise me, for you have taught me to expect them. Did I deserve the opprobrious epithets you have bestowed upon my character, I fear I should not be worthy of that ' respect from the respected' which I have throughout life endeavoured to gain, and which I have reason to believe I now enjoy.

"You are quite right when you assert that $I$ sought 
you in the first instance. No one has a higher estimate than myself of your talent, and the 'Heart of Gold' was written in consequence of my expressed desire to possess a play from a man of your genius and celebrity. It is quite true that I have had that play by me for three seasons. It was not acted during the two first seasons, as you already know, from the unfortunate disagreement between me and * * *.

"During the present season, you will remember, you were put aside only for yourselF. When you wrote the comedy of 'St. Cupid,' you sought me, because at the time you wanted money, which I at once advanced. And to suit your interest, quite as well as my own, it was determined between us that 'St. Cupid' should take the place of the 'Heart of Gold' (which was then about to be presented) and be acted first. In our third compact, which you afterwards thought proper to break, you again sought me, because again you wanted money, which $I$ again at once advanced. $A$ year elapsed, and you had not written one line; you declined fulfilling your agreement with me; and the money I had last advanced, namely, $100 l$, , was returned to me with $5 l$. interest.

"To meet your evident desire that the "Heart of Gold' should be brought out without any further delay, I purposed making it the first novelty of the ensuing season, and the scenery was already in progress. I cannot understand the damaging alteration of cast of which you complain. I never contemplated withdrawing Mrs. Kean from Maud; Mr. Harley is cast the character you expressly wrote for him; and when I mentioned Mrs. W. Lacy, you appeared perfectly satisfied with her for the maid. The only alteration, then, is the substitution of Mr. Ryder for myself as John Dymond, which, in theatrical parlance, is a rugged, 
heavy character, and an elderly man. Mr. Ryder is a good actor, and certainly a favourite at the Princess's, while in other parts he seems acceptable to you. I cannot, then, see what serious damage you can imagine the east sustains by the simple removal of an actor whose value you are ever endeavouring to depreciate. I never expressed any partiality for the part of Dymond, for I do not think it suited to me; but would very willingly have done my best with it to have satisfied the views and wishes of a popular and friendly author ; although I see no reason why I should in the slightest degree inconvenience myself for one who studiously seeks occasions to indulge in unprovoked hostility towards

"Yours faithfully,

"Charles Kean.

"I quit London for the Continent on Saturday, and shall be happy to hear from you respecting the re-purchase of your play, on my return in October."

"To Douglas Jerrold, Esq.

“Royal Princess's Theatre, "11th October, 1853.

\section{"Dear Sir,-}

"Having returned to London, I am anxious to ascertain if you are now prepared to carry out your own proposal of re-purchasing the 'Heart of Gold.' Your answer will oblige

"Yours faithfully,

$$
\text { "Charles Kean." }
$$


"To Charles Kean, Esq.

“26, Circus Road, St. John's Wood, "October 12, 1853.

"Dear Sir,-

"My proposal to re-purchase the 'Heart of Gold' was, as you will perceive, purely provisional. I have beset no manager with any communication on the matter; and from the aspect of the British theatre in 1853 , I see no likelihood of any very successful issue from the representation of the play elsewhere. I can only wish that the time bestowed upon it had been employed on any other composition, that would have borne, as it might, immediate results. Any way, in the present condition of the London stage, I cannot give any further attention to a matter that has been productive only of annoyance and disappointment to "Yours faithfully,

$$
\text { "D. JERROLD." }
$$

" To Douglas Jerrold, Esq.

" Royal Princess's Theatre, "Oct. 13th, 1853.

"Dear Sir,-

"Your letter of yesterday's date has required me to refer to our correspondence, in which you volunteer the proposal of re-purchasing your play of the 'Heart of Gold.' In yours of the 25th of August last, you say, 'Possibly I may be enabled to relieve you of my drama. In the event of finding another theatre, are you disposed, the money being re-paid, to return the drama?' And again, on the 30th August, you write, ' I do not return to London until the end of September; I will then, should I find my drama available else- 
where, of which I have little doubt, re-purchase it of you.'

"From these two communications I naturally concluded you had some arrangement in immediate view. You are scarcely likely to find a purchaser, unless you looked for one; and if you have 'beset no manager' with any communication on the subject, I confess I do not see how any manager could know you had such an article to dispose of. There are two points in your letter I am unable to understand. First, how the aspect of the British theatre in 1853 can have changed during the short interval of seven weeks, which has elapsed since you made your first overture to me on the subject. And, second, whether your expression, 'I see no likelihood of any very successful issue from the play elsewhere,' is intended as a compliment to my particular theatre, or as an oblique condemnation of the insufficiency of all theatres. Having paid you 300l. down on delivery of the play, in my humble judgment the 'immediate results,' as far as your interests are concerned, have assumed a tolerably substantial form. Mine, I regret to say, are for the present in rather a dim perspective; and the delay has been principally occasioned by your own proposal, which, I now understand, you find yourself utterly unable to carry out.

"I am, dear Sir, yours truly,

$$
\text { "Charles Kean." }
$$

"To Charles Kean, Esq.

“ 26, Circus Road, St. John's Wood, " Oct. 1Sth, 1853.

"Dear Sir,--

"I have little to add to my last. Should an opportunity present itself, promising a fair production of my drama elsewhere than at your theatre, I shall most gladly 
carry out my first provisional intention of re-purchasing the play.

"Considering that you are the person who has, originally, broken faith in the matter, it is I who have the right of complaint, for procrastination and final disappointment. I have only to repeat that I did not seek you, and am heartily sorry that you ever addressed yourself to

"Yours faitlifully,

“D. JerRold."

"To Douglas Jerrold, Esq.

"October 14th, 1853.

"Dear Sir,-

"My reply to yours, of this date, shall be comprised in very few words, and will, I sincerely hope, close our correspondence. Argument having failed, you seem disposed to retire on personalities. There I confess my inability to engage, and must decline to follow.

"I most emphatically deny ever having 'broken faith' with you. This is a chimera of your own creation,-an imaginary disappointment,-which I think you will find it very difficult to substantiate beyond mere assertion. You say you are 'heartily sorry that I ever addressed myself to you.' The balance of regret ought to weigh heavily on my side; as, on looking over my books, I find I have paid you $600 l$. for two plays (one as yet unacted); and that sum is considerably under the loss I sustained by 'St. Cupid.'

"Yours faithfully,

"Charles Keax." 
Before closing the subject, we have yet a remark to make on Mr. Blanchard Jerrold's book. At page 11 of his preface, in reply to some communications sent to the Press, an American paper, by a London correspondent, he says :-

"Then the American public is informed that Douglas Jerrold was 'down' upon Mr. Charles Kean, in Lloyd's Weekly Newspaper, till his death, because he conceived that Mr. Kean had purposely contrived the failure of the 'Heart of Gold.' The fact is that, after this piece was produced, my father never wrote a line about Mr. Kean or his management in the said newspaper."

Mr. Blanchard Jerrold's memory has sadly failed him, or he would have scarcely ventured this strong assertion. We cannot expect our readers to waste their valuable time by wading through the heavy columns from November, 1854, to April, 1857. We supply them with an index to save that trouble.* They will there find abundant evidence that the series of notices on Mr. Kean and his management was continued, whenever the production of a new piece supplied the opportunity, in the same strain, and carrying internal evidence, which carnot be mistaken, of proceeding from the same pen. A denial of the latter inference would amount to a transparent quibble. There are the articles, to speak for themselves, inserted by Mr. Douglas Jerrold in the paper of which he was the sole editor. He is as much responsible for their paternity as if they stood acknowledged by his signature at full length.

* See, in the Appendix (B) extracts from Lloyd's Weekly Newspaper, Nov. 12th, 1854 ; Jan. 14th, 1855 ; Jan. 21st, 18.55 ; Jan. 28th, 1855; Feb. 4th, 1855; March 18th, 1855; April 15th, 1855; May 20th, 1855 ; May 27 th, 1855 ; June 10th, 1855 ; July 8th, 1855 ; July 22d, 1855 ; Aug. 31st, 1856 ; Oct. 19th, 1856 ; Oct. 26th, 1856 ; Nov. 9th, 1856 ; March 15th, 1857. 
All well-wishers to the stage may probably regret that a dramatic author should ever combine the apparently incompatible functions of a dramatic critic. If his play be rejected or ill received, not being able to retort on the public, the manager presents himself as a ready scapegoat on whom to vent with pen or influence the overflowings of his disappointment. The case under discussion presents a remarkable instance. For years, Mr. Douglas Jerrold avails himself of a two-fold public channel, entirely at his command, to undermine as far as his power extends Mr. C. Kean's professional reputation, to cry down his most successful efforts, and to hold him up to ridicule and contempt. But when Mr. C. Kean, after long forbearance, privately defends himself for the satisfaction of his friends, he is charged in the coarsest terms with a departure from the courtesies of refined society, and the meanness of violating the confidence of honourable minds.

We have stated the facts: the commentary we leave to the public. 


\section{CHAPTER V.}

FOURTH SEASON OF MR. C. KEAN'S MANAGEMENT AT THE PRINCESS'SSARDANAPALUS CONTINUED WITH UNCEASING ATTRACTION-SHERIDAN's COMEDY OF THE RIVALS-THE LANCERS, ADAPTED FROM THE FRENCH, BY CAPTAIN L. VERNON-A MODERN FASHIONABLE DRAWING-ROOMARTICLE IN A WEEKLY PAPER, ON THE WINDSOR THEATRICALS-STATEMENTS ANSWERED-LARGE SUMS PAID FOR ORIGINAL DRAMAS-LONG AND SERIOUS ILLNESS OF MRS. C. KEAN-PANTOMIME OF THE MILLER AND HIS MEN-REVIVAL OF RING RICHARD III.-COLLEY CIBBER'S ALTERATIONS-GREAT DIFFERENCE OF OPINION ON THIS POINT-REASONS FOR ADOPTING THE ALTERED PLAT-RESULT NOT SATISFACTORYSUPPOSED CAUSES-MARRIED UNMARRIED-AWAY WITH MELANCHOLY, AND A STORM IN A TEA-CUP-MAGICAL SPECTACLE OF FAUST AND MARGUERTTE-MR. C. KEAN'S MEPHISTOPHELES-FROM VILLAGE TO COURTTHE COURIER OF LYONS PRODUCED FOR MR. KEAN'S BENEFIT-HIS PERFORMANCE IN THE DOUBLE CHARACTERS OF LESURGUES AND DUBOSCCLOSE OF THE SEASON-NUMBER OF PIECES PERFORMED-MELODRAMA AND HIGH TRAGEDY.

THE fourth season at the Princess's commenced on Monday, the 10th of October, 1853, with "Sardanapalus," which appeared to have lost none of its attraction. The old comedy of the "Rivals" was revived, and with the beginning of November the performances were varied by the production of a highly interesting drama, in three acts, entitled the "Lancers; or, the Gentleman's Son," freely adapted by Captain Leicester Vernon, M.P., from the "Fils de Famille," of Monseiur Bayard, performed during the preceding year with unusual success at the Gymnase, in Paris. This piece was acted for forty-nine nights, and gave universal satisfaction. Nothing could be more complete than a 
fac simile of a modern drawing-room, which was represented in the second act, on a stage principally filled by subordinate actors. It is not easy to marshal a mimic army on the boards, to go through the evolutions of a battle, to arrange a triumphal or civic procession, or to produce the trained confusion of a mob of rioters; but it is far more difficult to present a full company of ladies and gentlemen arrayed in fashionable attire, and moving with the ease of polished society. It is a curious fact, in the peculiarities of acting, that in private theatricals, where the performers are chiefly drawn from the aristocratic circles, civil or military, the break-down generally occurs in the representation of the high classes, who become stiff and awkward when required to assume theatrically what may be termed their natural attributes. Amateur low comedians, such as Jem Baggs or Bill Mattock, are more plentiful than Rangers, Doricourts, or Mirabels. The eccentric Lord Barrymore was inimitable in the ignorant vulgarity of Scrub, but failed when he attempted the airy elegance of Archer.

The altered tone of Mr. Douglas Jerrold's mind, in regard to Mr. C. Kean, had for some time manifested itself in a series of depreciating sneers, and insinuations, through the ready medium of the two papers before named. On the 13th of November, 1853, he opened a direct attack (the immediate occasion for which presented itself in a recent performance at Windsor Castle). An article in Lloyd's Weekly Neuspaper contained these passages, under the head of

"THE GREAT KEAN MONOPOLY.

"The Kean monopoly has been broken through. Mr. Phelps performed 'Henry the Fifth,' at Windsor Castle, on 'Thursday last. He has been the first to find a northwest passage to the palace. The passage once found, 
others may quickly follow. The difficulties of the passage no one can conceive, but those who have had to steer through the immense blocks of ice which Mr. Charles Kean has thrown in the way of his brother managers. .... He has used this privilege for the glorification of himself as an actor and a manager, until the Queen and the Court have been brought to believe that there was but one English actor, and but one English theatre; that actor being Mr. Charles Kean, and that theatre being the Princess's !! . . . W We hope a dramatic commission will be issued from Windsor Castle (and how proud we shall be if we are nominated to sit upon it !) to inquire into the following questions :-

"How far the patronage bestowed upon Mr. Charles Kean has benefited the drama?

"How often he has allowed other managers to perform? - and the number of times those managers have performed in comparison with Charles Kean?

"To inquire how often Mr. Phelps has performed at Windsor Castle, before Thursday evening, November 10th, 1853?

"To discover the names of the other tragedians who have played at Windsor Castle, by the kind permission and favour of Mr. Charles Kean?

"To ascertain, if possible, the number of original pieces Mr. Charles Kean has produced since he has been in possession of the patronage of the court?

"On the other side, to ascertain the number of revivals, adaptations, and more particularly translations, which Mr. Charles Kean has produced during the same period?

"To find out the sum of money, if possible, which Mr. Charles Kean has paid to living authors for the encouragement of the drama, since he has been manager of the Princess's? 
"On the other side, to find out the sums of money which Mr. Charles Kean has paid to translators for the discouragement of the ditto, during the same period?

"To investigate the principles, if any, of $\mathrm{Mr}$. Charles Kean's management?.... And lastly to state the extent of injury which the English stage would suffer, and whether it would be more weak and ailing than it already is, if Mr. Charles Kean were to lose to-morrow the lucrative situation which he at present holds at Court, of 'Wet Nurse to the British Drama?'

"If the above commission is issued, we shonld like of all things to be present during Mr. Charles Kean's examination. In the meantime, Mr. Phelps has broken up the great Kean monopoly; and the monopoly now broken, we hope that henceforth dramatic free trade will reign at the palace in its stead. The actor's loaf and the author's crust (for where the former gets a loaf the latter only gets a crust) both depend upon it."

On reading this article it is difficult to decide whether disrespect to the Court or animosity against Mr. C. Kean constitutes the prominent feature. A string of assertions and inferences such as we find here lie beyond the scope of argument; their valuc can only be tested by facts. How do the facts stand in the case before us? The evidence of printed bills and authenticated accounts present them as follows :-Previous to his performance of Henry the Fifth at Windsor Castle, Mr. Phelps had appeared there in the characters of Francesco Agolanti, in Leigh Hunt's " Legend of Florence," in Hubert (" King John"), and in the sick King, in the second part of "Henry the Fourth." When "Henry the Fifth" was proposed, by the Court, as one of the Windsor plays, during the season of 1853, Mr. Kean was asked to represent the hero. He remarked that he had never yet acted the part, but that Mr. Phelps had, and suggested the proVOL. II. 
priety of its being committed to that gentleman. The suggestion was acceded to. Mr. Macready, Mr. Vandenhoff, and Mr. James Wallack had also been included in the casts of "Julius Crsar," "Hamlet," and "Charles the Twelfth." Up to the date of Mr. Douglas Jerrold's article, thirty-two dramatic pieces had been performed; eleven of these before.Mr. Kean became a manager. Nine were supplied from the resources of his own theatre ; the remaining twenty-three chiefly from the Haymarket, the Lyceum, Sadler's Wells, and the Adelphi. Mr. C. Kean had himself performed eleven times, Mrs. C. Kean eight, Mr. Webster seven, Mr. C. Mathews five, Mr. Keeley ten, and Mr. Buckstone three. The power and patronage so emphatically denounced by Mr. Douglas Jerrold, consisted, as far as Mr. C. Kean was concerned, in carrying out the wishes and views of his illustrious employers; the lucrative monopoly in the disbursement of a large sum of money. Mr. Kean volunteered his gratuitous services as manager, which were graciously accepted. He might venture respectfully to name a particular performer or play if asked to do so; but no reasonable person will suppose for a moment that he could presume to step beyond that point; his functions were to obey and not to dictate. When an opportunity offered he exercised the permission of suggesting, as in the special instances of Mr. Phelps for Henry the Fifth, and Mr. Douglas Jerrold's play of "St. Cupid," which, through his earnest recommendation, received the stamp of court favour before it was submitted to the public. But notwithstanding this, the play proved, in a commercial sense, a failure. The "actor's loaf" and the "author's crust" changed the relative value, which Mr. Jerrold assigns to them; the former being represented by the Algebraic figure (ninus) to the amount of something like $800 l$; the latter exemplified by + (plus) $300 l$. 
Leaving the topic of the Windsor plays, the points so broadly insinuated in other portions of the article are equally answered by simple facts.

During his three years of management, Mr. C. Kean had accepted and paid for nineteen original dramas, of which fifteen had been already acted, with eleven adaptations or translations. The Shakespearean revivals amounted to nine. For the original pieces he had paid 3,6857 .; for the adaptations and translations, $1,1357$. ; total $4,820 l$. Of this large amount, $600 l$. had been received for two pieces by the writer of the article, who publicly called upon Mr. Kean to show "the sum of money, if possible, which he had paid to living authors for the encouragement of the drama, since he had been manager of the Princess's?" Within two seasons after the date to which these particulars refer, Mr. Kean paid nearly $2,000 l$. more for costly novelties which were seldon productive. Such experiments cannot be repeated ad infinitum. They enforce their own termination, by the most coercive of all arguments-a heavy balance on the wrong side of the ledger.

With the commencement of 1854 , the arrangements of the season received an important check in the serious illness of Mrs. C. Kean, which occasioned the substitution of Miss Murray for her part of Myrrha in "Sardanapalus," and necessitated a total change in the general plan. For a long interval of nearly eighteen months, the public lamented the absence of one of their greatest favourites, while her lusband, losing her invaluable co-operation, felt himself placed in the position of a leader deprived of his right arm.

The pantomime on the old familiar subject of the "Miller and his Men," proved to be one of the most attractive that had been brought forward of late years. Some original and highly effective tricks transported 
rom Paris produced an extraordinary sensation. The value of a good pantomime trick in these days, if entirely new, is equal to that of a virgin nugget. On Monday, the 20th of February, 1854, "Richard the Third" was revived with great splendour. In this instance Mr. C. Kean departed for once from his system of a pure restoration of the text of Shakespeare, and adopted the longsanctioned amendments of Colley Cibber. It was a point of much difficulty on which he deliberated long before coming to a decision. Shakespeare's tragedy, under the title of the "Life and Death of King Richard the Third," had been essayed at Covent Garden on the 12th of March, 1821, the principal character being then sustained by Mr. Macready. It was coldly received, and a single repetition, a week after, on the 19 th, wound up the experiment. Something was gained in the restoration of the entire part of Queen Margaret of Anjou, and Clarence's dream, but more was lost by the want of condensation in the latter portion of the play; while the scene of the impeachment of Hastings so long pilfered by Rowe, in his " Jane Shore," fell flat from being already too familiar.

The reasons which influenced Mr. C. Kean's preference of the altered version on the present occasion, were set forward as follows, in the fly-leaf:-

"It is now a general conviction, that to do justice on the stage to the immortal productions of Shakespeare, they should be represented, as closely as possible, in conformity with the ascertained text of the poet; and in the Shakespearean revivals which liave taken place of late years, at more than one theatre, a laudable endeavour has been made to keep this salutary object in view. If a departure, then, from a rule which it behoves every true lover of his art to follow with loyal fidclity, occurs 
at any time, some apology or explanation would seem due to the public for the rare exception.

"In selecting the play of ' King Richard the Third,' I have, upon mature consideration, decided on adopting the well-known version of Colley Cibber, instead of going back to the original text of Shakespeare. That text has been practically'declared by the greatest ornaments of the drama, less fitted in its integrity for representation on the stage than almost any other generally acted play of the great poet; whilst, on the other hand, the tragedy, as modified by Cibber, being rather a condensation than an alteration of Shakespeare (the interpolations themselves being chiefly selections from his other plays), has been pronounced one of the most admirable and skilful instances of dramatic adaptations ever known. David Garrick made his first appearance in London, in 1741, in Colley Cibber's version of 'King Richard the Third;' and Henderson adopted the same play; the classical John Kemble followed deliberately in the wake of his great predecessors; and to these succeeded George Frederick Cooke, and my late father, Edmund Kean. With such distinguished precedents for my guide, I might well hesitate in reverting, on the present occasion, to the original text, even if their judgment had not been sanctioned by the voice of experience, and were it not also a fact that the tragedy of 'King Richard the 'Third,' as adapted by Cibber, is most intimately associated with the traditionary admiration of the public for those renowned and departed actors.

"There may be a question as to the propriety of tampering at all with the writings of our bard: but there can be none that as an acting play, Colley Cibber's version of ' King Richard the 'Third,' evinces great dramatic judgment, and a consummate acquaintance with scenic effect. To be convinced of this, it is sufficient to glance 
at the skilful arrangement of the fifth act; and there can be no doubt, that a careful comparison of the original and the altered tragedy, left no choice to the masters I have named, who were naturally anxious to present the work in the most striking and spirit-stirring form before the eyes of the spectator.

"In the production at this theatre of 'Sardanapalus,' 'Macbeth,' and ' King John,' I have selected different periods of history for illustration, and have endeavoured to arrive at every available authority, with the view of transferring, as far as possible, to the stage, a living and pictorial embodiment of the past. 'King Richard the 'Third' affords a new epoch, distinct from all the foregoing, and I have taken the same pains to give proper scenic and decorative effect to this most busy and eventful chapter of our annals.

"The following authorities have been consulted:'Meyrick's Ancient Armour,' 'Col. C. H. Smith's Ancient Costume of Great Britain,' 'Planché's unpublished work on the Costume of Richard III.,' 'Strutt's Dresses and Habits of the People of England,' 'Fairholt's Costume in England,' 'Fosbroke's Encyclopædia of Antiquities,' 'Dugdale's Monasticon Anglicanum,' 'Shaw's Dresses and Decorations,' 'Stothard's Monumental Effigies,' 'Froissart's Chronicles,' 'Pugin's Glossary of Ecclesiastical Ornament and Costume,' and the Herald Office."

"Richard the Third," in its new form, ran only nineteen nights, a short career and a very limited success for a great Shakespearean revival at the Princess's. The result was disappointing to the manager, and unexpected by his admirers. Where was the cause of this comparative failure to be sought for? Not in the acting, for it was loudly applauded by the audience, and eulogized warmly in the leading papers. Mr. C. Kean had won 
much of his early London reputation in the "Crookbacked Tyrant," and his performance now, as might be expected, was far superior to what it had been in 1838 , and 1841. The whole action of the play centres in Richard. He is the pivot on which every movement turns; an Atlas who carries the entire weight on his shoulders. Seldom absent from the scene, his controlling agency pervades the collected dramatis personce, who appear as obedient machines directed by lis single will. He is all evil like $J_{o h n}$, unillumined by even a glimmering of humanity; but he is, unlike the earlier Plantagenet, gifted at the same time with a subtle and commanding genius, and moves through the scene a master demon of irresistible power: From his entrance to his fall, the mind and eye of the spectator are riveted on his proceedings. $\mathrm{He}$ fascinates like the rattlesnake, although you know that his spring is death. The character is altogether one of the most arduous and complicated in the range of the drama, requiring from its representative a combination of mental and physical energy seldom united in the same individual. The finest conceptions pass for nothing, if the actor lacks the more telling faculty of execution. Richard is alternately restless and contemplative; thoughtful in arranging his schemes, rapid and decisive as lightning in carrying them into execution; hypocritical and audacious; gloomy and sardonically humorous ; remorscless, but accessible to the terrors of conscience; cunning and bold; treacherous and heroically daring. He is a perpetual contrast, a multiplied antithesis, as crafty as Ulysses, as variable as Proteus, and more full of unscrupulous expedients than Machiavel himself. The actor who can embody all these opposing passions and sentiments in one portrait of brilliant colouring, is undoubtedly a mighty master in his art. Mr. C. Kean accomplished this, and fully vindicated his title to the 
post which public opinion has accorded to him, after long years of trial and study, and in which he has never been supplanted -that of being the first and greatest tragedian of his day. From his entrance, in close soliloquy with himself, until his desperate combat and dying agony on the field of Bosworth, all was sustained in perfect keeping with the character, and fearfully impressive. For passages of superior merit, we might select the entire scene with Lady Anne, the soliloquies, all marked by variety and concentrated meaning, the repulse of Buckingham in the fourth act, the delivery of the celebrated line, "Off with his head-so much for Buckingham!" the tent scene ; and, above all, the exclamation, "Who's there?" on the intrusion of Catesby into his tent. In all these points Mr. C. Kean produced effects startling as they were original, and calling forth enthusiastic applause. The modern play-going public indulge too sparingly in these demonstrative evidences of their satisfaction. Without encouragement the most effervescing actor becomes chilled. Mrs. Siddons and John Kemble used frequently to declare that they were unable to exert their full powers to a cold or a pathetic audience. On the revival of which we are now speaking, every part down to. the inferior subordinates was efficiently represented, and when to such acting is added the gorgeous perfection of stage paraphernalia and historic accuracy of which our ancestors had no conception, entertainment is thus profitably blended with instruction, and the theatre becomes in reality, what its sanguine advocates have long predicted it might be brought to, a valuable school of antiquarian illustration, and a living lecture on the past.

Why, again we ask ourselves, did this fine play, tlius presented, fail to excite the public or draw them in crowds to the theatre? We can only conclude that it was because Cibber's adaptation had lost its time- 
honoured credit, and nothing now would be tolerated but genuine, unadulterated Shakespeare. And yet, on the other hand, if the original play had been preferred, and condensed within acting limits, we doubt much whether the result would have been more satisfactory. Accident and caprice are so mixed up with the fate of all theatrical ventures, that they baffle the soundest judgment and the longest practice. But opinions sink in value when the opportunity of testing them by experiment has passed away.

On the 28th of March, a serious drama taken from the French by Mr. Morris Barnett, was produced under the title of "Married Unmarried," and was most favourably received. The principal parts were well acted by Mr. Ryder, Mr. W. Lacy, Miss Heath, and Miss Murray. It was repeated fifty-eight nights, but after the first attraction subsided, was forgotten with many others of a similar class. Two very amusing farces, "Away with Melancholy," by Mr. J. M. Morton, and "A Storm in a Tea-Cup," by Mr. Bayle Bernard, were also called in to vary the performances.

On Wednesday, in Easter week (April the 19th), a more important novelty formed the principal feature of the bill, under the title of "Faust and Marguerite," a magical drama, adapted from the French. During Mr. C. Kean's theatrical career, he has scarcely achieved a more decided triumph as an actor than in this singular production. It presented him a new line, totally distinct from any in which he had courted distinction on earlier occasions.

The subject of this mclodramatic spectacle had long been familiar to many in the German of Göethe; in more than a dozen English translations by writers of eminence, all of whom have conveyed much of the true spirit of the original ; and also from a more recent repre- 
sentation of the play by the German company at the St. James's Theatre in 1852. It excites some surprise that a composition of so much inherent power, and withal so popular and well-known, had not been transferred to the English stage at an earlier period. The operatic play named "Faustus," produced with considerable although ephemeral success at Drury Lane, in 1826, had scarcely any connexion with the imaginative story of Goethe beyond the name. He himself, in all probability, had never read the old drama of Marlowe, which the affected lovers of black letter are wont to praise upon hearsay; and if he had, he disregarded it. When the great German philosopher composed this renowned work, which crowns his reputation, he had no view to the production of an acting drama. He thought little of the applauses of the pit, the marvellous expression of the actor, or the resources of the mechanist. $\mathrm{He}$ adopted the dramatic form, because it presented greater facilities than either the epic or didactic of carrying out in continuous dialogue the profound subtleties and elaborated disquisitions, the varieties of thought and feeling in which his subject was likely to entrain him. His "Faust" is, in fact, a complicated moral essay, an anatomical investigation of the heart of man, partaking more of the nature of a metaphysical poem than of a represented play; while, at the same time, it contains many of the most essential and prominent requisites of the latter, in incident, contrasted character, and exciting. situations. There are some indelicate passages, and others that more than border on inpiety; but they are not taken into account by the enthusiastic admirers of Goethe, who overlook small blemishes in a galaxy of beauty. The French playwright, M. Michel Carré, has availed himself of the dramatic elements, with the peculiar tact in construction for which our neighbours are so 
remarkable, and wherein we must yield them the palm of superiority without dispute. The plan he followed has been carried out with even improved success by the English adapter. The French piece was produced in Paris at the Théâtre du Gynnase, on the 19th of Auyrust, 1850. The version performed at the Princess's was closely modelled upon this, with some very material alterations, all tending to one point-increased effect. The charm of the romantic drama lies in quick and varied action, which keeps the attention of the spectator ever on the alert, and excites without wearying him, To produce this, in the present instance, great pains were taken to clear up the somewhat dreamy philosophy of Goethe; to connect his disjointed plot; to confine the incidents retained to a consecutive series; and to relieve the deep sardonic malignity of Mephistopheles by an infusion of light, satirical humour, which makes him sometimes amusing, and almost human, instead of being ever demoniacally appalling. By these means, the general effect is rendered less oppressive, while the interest of the situations and the point of the moral are in no degree weakened. We lose, it is true, the poetical flights occasionally mystified, more Germanico; and instead of transcendental philosophy we have clear conversational dialogue, which by some sharp critics was condemned as homely and even vulgar.

There were, and are still, divided opinions as to the moral and religious tendency of this singular drama. Some objectors wondered how it passed the censorship of the Lord Chamberlain, and loudly questioned the orthodoxy of the conclusion; but the public poured in in crowds to see a beautiful and original exhibition. Few pieces have been more permanently attractive. The greater share of this success was due to Mr. Kean's acting in Mephistopheles. The entire business of the scene, as 
with Richard the Third, centres in him. He pulls the wires and the obedient puppets respond to his call. The character stands alone, and is exclusively suigeneris, belonging to no previous class, and without prototype or parallel. The actor has no model to set before his mental or physical eye as a guide. He cannot turn to established conceptions or conventional rules. $\mathrm{He}$ must create a style suited to an identical portraiture, unlike any he has ever studied before, either in contemporary life, in poetry, history, fable, or tradition. The attributes which distinguish Mephistopheles have no analogy with those required for Hamlet, Macbeth, Romeo, Lear, Shylock, or Benedick. To conceive and execute this strange novelty, demands a concentration of strength, a distinctness of purpose, and a versatile imagination, seldom indeed combined. These faculties Mr. Kean developed in his personation with admirable skill. Throughout he was cool, self-possessed, decisive, original, and certain of himself. The Mephistopheles of the drama is too conscious of his power to forget his constitutional irony, his contempt for man, or to indulge in ebullitions of mere human anger or emotion. He plays with his victims as the cat does with the mouse, or the angler with the trout, which he has securely hooked and can land when he pleases. The character would be intolerable, but for the humour with which it is ingeniously invested. Mr. Kean's embodiment of this unique portrait has been generally pronounced one of the most extraordinary specimens of histrionic art the stage can boast. It can only be understood by being seen, and that more than once before its merit can be thoroughly appreciated. It is, in fact, a thing to arrest and absorb the faculties of the spectator while the play is in progress, and to beset his imagination for hours after. Individual points are not easily particularized, neither 
does the part admit of minute dissection. It must be taken as a whole, and judged in its integrity. Mephrstopheles is seldom absent from the scene, and you feel him as intensely when he is not present as if he stood before your eyes. Even while he is silent, his expression speaks with more eloquence than language. In actual bulk of words he says little, but every syllable has weight. His speeches are epigrams, with a sting at the end of every line.

On the 5th of June a lively and successful drama in two acts by Mr. J. M. Morton was produced under the title of "From Village to Court," adapted, as usual, from the French, and on the 26th of the same month, Mr. C. Kean selected for his benefit a second melodrama founded on a remarkable trial with a melancholy result, and called the "Courier of Lyons." * For the moment the series of Shakespearean plays was suspended, much to the injury of the manager's exchequer, and the gratification of the public, by the long-continued illness of Mrs. C. Kean.

The judicial fact which supplies the materials for the "Courier of Lyons," occurred in Paris during the early period of the Revolution, under the rule of the Directory. A robbery and murder of the most atrocious nature was committed by three accomplices; two were taken, but the third, and principal contriver escaped. A person of respectable rank in society, and of unblemished character, totally innocent, was arrested on strong suspicion, arising from his extraordinary resemblance to the real criminal. Direct evidence of identity was produced, and sworn to, against him. He was tried, condemned, and guillotined with the other two. Shortly after, the true culprit was discovered, and the fatal mistake became publicly known. The family of the unfortunate victim (a second

"See the French "Causes Célebbres." 
Calas), under the early consulship of Napoleon, instituted a suit for the restoration of his property, which had been confiscated according to law, and succeeded in obtaining a reversal of the sentence, with the full acknowledgment of their rights. The subject, with altered names and locality, was dramatized nearly thirty years ago, but never produced on the London boards.: The version from which the present English adaptation, by Mr. Charles Reade, is taken, was first acted at the Theâtre de la Gaieté in Paris, on the 16th of March, 1850. By permission of his living representatives, the real name of "Lesurgues" was restored to the principal character. In Paris there was a double catastrophe, alternately represented to suit opposite tastes. According to one, Lesurgues was executed, and by the other reprieved. The English adapter and manager rejected the variation and preferred sending the audience home in a happy mood. In other respects the drama was greatly condensed, the parts heightened, and the interest concentrated, to bring it more in accordance with English taste.

The piece is one of rapid and exciting action. The interest begins with the beginning, never flags, and rises gradually to the conclusion, keeping the audience in an agony of suspense to the last moment. As a melodrama it ranks high in its class. Of Mr. Kean's acting in the two characters of Dubosc and Lesurgues it is impossible to speak in warmer terms than it deserved. The effect was far more striking than in the "Corsican Brothers," as the features of the parts are thrown into stronger contrast, and afford a wider scope to the executive variety of the artist. Nothing can be more opposed than the vulgar, coarse villainy of the one, and the refined, honest, and manly fervour of

- A translation was acted in Dublin in 1827, under the title of the "Courier of Naples." 
the other. The changes are absolutely miraculous. The actor leaves the stage at the left hand side, and in a moment appears at the right-the same individual in person, but a different character, changed in costume, and utterly opposed in manners. The distinct identity and attributes of each were never lost sight of or confounded for a single instant. To preserve this in perpetual alternations through a long play is in itself a physical task demanding unusual power. The appearance of the double at the winding-up was a mechanical mystery which many spectators witnessed for a score of times without satisfying themselves how such an instantaneous substitution could be contrived. Her Majesty and the Prince Consort occupied the Royal Box on the first night (their attendance being a marked compliment to Mr. Kean on the occasion of his benefit), and appeared to be wrapt in deep attention by the interest of the scene. The "Courier of Lyons" came out late in June, a position which only allowed twenty-six repetitions up to the last night. It was renewed when the theatre opened again, and attracted nearly the same number of gratified audiences.

Mr. Kean closed his third season on the 9th of August, 1854. The number of different dramas played amounted to eighteen; the novelties, including the pantomime, to eight. The protracted illness of Mrs. Kean disarranged the plans of the season, compelled the suspension of the projected Shakespearean revivals, and drove the manager, as a matter of expediency rather than choice, to substitute melodramatic spectacle more prominently than he intended. By the performance of such parts as Mephistopheles, and the blended Dubosc and Joseph Lesurgues, he afforded his detractors an opportunity which they greedily embraced of saying that, although unrivalled in melodrama, he was not a tragedian of the 
first class ; forgetting the long range of the highest and most legitimate tragedy on which his progressive reputation had been built. Such objections, when wanted, spring up as rapidly as mushrooms, in equal abundance, and from similar ground. The modern romantic drama embraces a mixture of components which assuredly do not carry the mind up to the classic elevation of the Sophoclean or Shakespearean tragedy. But an actor of skill and taste may raise an inferior branch of the art to which he stoops occasionally, without detriment to his own fame; and of this an eminent instance will present itself when we treat of Mr. Kean's performance in "Louis the Eleventh."

Garrick was condemned by some of his enthusiastic advocates for descending to Abel Drugger, Scrub, and Fribble; but by so doing he proved his boundless versatility, and gave additional contrast to the passion of Lear, the hypocrisy of Richard, and the melancholy grace of Hamlet. 


\section{CHAPTER VI.}

DRLAYED COMMEXCEMENT OF THE FIFTH SEASON AT THE PRINCESS'SCHOLERA IN LONDON-SUDDEN ILLNESS AND DEATH OF MRS. FITZWILLIAM-DEATII OF MRS. WARNER-LIVING TOO FAST-MR. DOUGLAS JERROLD'S PLAY OF THE HEART OF GOLD - COMPARATIVE FAILCRESPECTACLE OF SCHAMYL THE CIRCASSIAN HERO-PANTOMIME OF BLUEBEARD-CASIMIR DE LA VIGNE'S LOUIS THE ELEVENTH, ADAPTED BY Y. DION BOURCICAULT-GREAT SUCCESS OF THE PLAY-EXTRAORDINARY IMPRESSION MADE BY MR, C. KEAN IN THE CHARACTER OF THE KINGCRITICAL ANALYSIS-THE AUTHOR, THE ACTOR, AND THE PLAY-COMPLIMENTARY LETTERS TO MR. C. KEAN.

Tre commencement of Mr. Kean's fifth • season was. delayed longer than had been planned, from two ineidental eauses, the one public, the other private-the visitation of Asiatic chorera in London, and his own illness, which detained him in Paris. The course of the destroying malady, which seems yet to be but imperfectly understood, was on this occasion as eccentric as that of a comet. Coming from the east, it paused with fatal effeet in the circumjacent vieinity of Golden Square, and passing up Poland Street to the south side of Oxford Street, immediately opposite the Princess's 'Theatre, halted as if a barrier had arrested its progress at that point. No eases penetrated to the north. This singularity has been even more strikingly exhibited in India. A regiment on the march, with the two wings divided by a ravine, has been stricken on the one bank and not on the other. It has also been recorded by officers serving in that country that the deadly and unseen enemy has been cheeked by firing vollies of blank cartridge in the air. These facts support the theory adopted by VOL. II. 
many, that, as regards cholera, atmospheric influence has much to do with the spread of infection.

This fearfully rapid disease deprived the stage of an actress of much celebrity, Mrs. Fitzwilliam, who died on the 11th of November, 1854, after an illness of a very few hours, being then only in her fifty-second year. She was born at Dover, where her father was manager, in a dwelling-house attached to the theatre. At five years old she began to act childish parts, and, at fourteen, was a leading actress in the Kent company. Her musical preceptress was Mrs. Bland, from whom she derived much of her peculiar charm in singing ballads and simple airs. In 1816, she appeared at the Haymarket, and subsequently removed to the Olympic and the Surrey, under Elliston and T. Dibdin. At the Olympic, she acquired notice by her performance as the Countess of Lovelace, in "Rochester," and at the Surrey surpassed Mrs. Egerton, the original Madge Wildfire, by the superiority with which she warbled the wild snatches of songs interwoven with the part. In 1821, she married Mr. Edward Fitzwilliam, a comic actor and vocalist, who left the stage in 1845 , and died in 1852. In 1832, Mrs. Fitzwilliam assumed the helm of management at Sadler's Wells, and took her farewell benefit there in 1839. She then visited America for a year, and on her return engaged at the Haymarket. She left behind her a son and a daughter. The former, a musical composer of rising fame, died prematurely. 'The latter lately filled an important situation in the theatre so long graced by her mother's abilities.

Mrs. Fitzwilliam was an artist in the school of Mrs. Jordan and Miss Fanny Kelly;--a school which has still a representative in Mrs. Keeley. The four preserve a succession which seems likely to terminate with the living inheritress. The line embraces chambermaids and 
country simpletons, impudent boys, Englishwomen of humble rank, whether serious or comic; and includes in all, the fascinating accompaniment of artless, unornamented songs and melodies naturally introduced, and illustrative of the character to which they are attached.

The death of Mrs. Fitzwilliam was followed within a fortnight by that of Mrs. Warner, which occurred, though from a very different cause, on the 24th of September. She had long suffered under a most painful and incurable malady, which prostrated her powers and rendered her incapable of acting for nearly a year and a half. Her last appearance in England was at Sadler's Wells in August 1851, where she represented Mrs. Oakly for her own benefit. She then went to America, and played with all the success that could be desired, when indications of cancer compelled her return to undergo an operation. Again she visited New York, but the rapid increase of her disease rendered acting impossible, and, in the spring of 1853 , she returned home, a hopeless invalid. From this period to the date of her death, she bore the most excruciating agony with surprising fortitude. Her Majesty the Queen warmly interested herself in the case, and allowed her the use of a carriage. Her friends exerted themselves to raise a fund for her support. Mrs. C. Kean, through her personal influence, obtained by far the largest subscription, amounting to $405 l$., $50 l$. of which was contributed by Mr. Kean and herself. This money was invested and paid in weekly proportions up to the day of Mrs. Warner's death. On the occasion of some judicial proceedings which took place in the bankruptcy court in December, 1853, the judge asked how the poor lady had been supported during the aftliction of her long illness. By the exertions of many kind friends, was the answer, mentioning the names of the parties, but those of $\mathrm{Mr}$. and Mrs. C. Kean were not even alluded to. The omis- 
sion might have been accidental or intended. In either case it was extraordinary. Mrs. Warner was endowed with great personal beauty, and powers of a high order in the delineation of matronly heroines. Her best parts were Lady Macbeth, Queen Katharine, Hermione ("Winter's Tale"), Emilia, in "Othello," and the Queen, in "Hamlet," which latter she performed at the Windsor theatricals in 1849. Her name will ever remain associated with that of Mr. Phelps in the honourable experiment of converting Sadler's Wells into a Shakespearean theatre. The announcement on the opening-night, May 27th, 1848, contained this passage :-

"Mrs. Warner and Mr. Phelps have embarked in the management of Sadler's Wells Theatre, in the hope of eventually rendering it what a theatre ought to be-a place for justly representing the works of our great dramatic poets. This undertaking is commenced at a time when the stages which have been exclusively called 'national' are closed or devoted to very different objects from that of presenting the real drama of England, and when the law has placed all theatres upon an equal footing of security and responsibility, leaving no difference except in the object and conduct of the management."

On this occasion, Mrs. Warner delivered an opening address, written by Mr. T. J. Serle, and sustained Lady Macbeth, to the Macbeth of Mr. Phelps. Fifteen years have since elapsed. The persevering energy of $\mathrm{Mr}$. Phelps has crowned the enterprize so boldly commenced in an unpromising locality with permanent success.

The season at the Princess's commenced on Monday, the 9 th of October, with a new comedietta, in one act, by a young author, Mr. A. C. Troughton, entitled "Living Too Fast; or, a T'welvemonth's Honeymoon." It was cminently successful, and has held its place on the 
stock list with undininished popularity. The writer has since produced other pieecs of a more important character, and has improved on his early promise. But the chief feature of the opening night was a drama, in three acts, by Mr. Douglas Jerrold, called "A Heart of Gold." This play, as we have mentioned in a preceding chapter, had been written for, and purchased by, Mr. Kean, prior to the acceptance of "St. Cupid," but by mutual agreement the order of respective production was reversed. Four years rolled on; actors left the company, others supplied their places, and important ehanges took place, interfering materially with the original arrangements.

The characters in "A Heart of Gold" were confined to homely life; there was no possible relief or aid to be supplied from show or pageantry, but there was something inherently dreary and uncomfortable in the plot, incidents, and final development. The general tone of notice in the papers implied, under kind expressions, an evident feeling that the work was below the standard of the author's reputation. The public confirmed their opinion by such a dull reception and slack attendance that the play was withdrawn after the eleventh representation, in consequence of deficient receipts. It had been most earefully rehearsed; new scenes were painted; and all the performers discharged their duty loyally, although the author, in his disappointment, laid much of the failure to their account.

On the 6th of November, the "Heart of Gold "was succeeded by a novelty of very opposite cast-a grand military spectacle, adapted by Mr. Palgrave Simpson, from a piece then playing in Paris with great success. The subject suggested itself from the political occurrences of the lour. Schamyl, the warrior-prophet of Circassia, had long been considered the delegated hero of the east. The liberation of his country from Russian 
thraldom, through his agency, was as confidently looked for on the opening of the Crimean campaign, as the capture of Sebastopol by a coup de main, the carrying of the fleet at Cronstadt by our gallant admiral's sharpened cutlasses, or the consequent conflagration of the docks and arsenals at St. Petersburgh. All these fondly indulged chimeras are, we doubt not, long since catalogued in the regions of the moon, as additions to the roll of unaccomplished events, examined by Astolfo when he ascended thither on his hippogriff in search of the lost wits of Orlando.

The spectacle, however, which cost enough to keep a small principality for a twelvemonth, ran only twentythree nights, and then died of sheer exhaustion. It helped, nevertheless, to fill up the time before Clristmas, when the pantomime, on the subject of "Bluebeard," raised the somewhat stagnant feeling of the play-going public.

An amusing incident occurred during one of the rehearsals of "Schamyl." A particular scene represented a cataract, above which, at a considerable elevation from the stage, a raft had to pass, occupied by three or four persons, one erect, and the others in stooping or recumbent positions. A considerable delay occurred. Mr. Kean, who superintended the rehearsal, called loudly to demand the cause. No answer. "Why does not the raft come on?" Again no answer. The question being reiterated, one of the actors, who should have been at his post, at last appeared from the back of the stage, and exclaimed with excitement, "The raft is unsafe, sir; it would endanger a man's life to venture on it! I really cannot incur such a risk." Some further discussion then arose, interrupted suddenly by a loud burst of applause from all who were looking on. This was occasioned by the appearance of the raft passing 
steadily across with Mrs. Kean standing in the centre, occupying the position of the apprehensive remonstrant. We need searcely say he was silenced by this eloquent reply.

Mistakes had been committed, and unexpected difficulties assisted also to mar the earlier part of the season. Up to this date, Mr. Kean had only appeared in the three melodramas of the "Corsican Brothers," "Faust and Marguerite," and the "Courier of Lyons," varied after Christmas by one or two occasional performances of "Hamlet," the "Stranger," and the "Iron Chest;" but on Saturday, the 13th of January, he burst on the town with renovated strength in a new drama of high legitimate nature, being an English adaptation by Mr. Dion Bourcicault, of Casimir De La Vigne's celebrated historical tragedy of "Louis the Eleventh." This play commanded sixty-two repetitions, and silenced all pertinacious denials of Mr. C. Kean's hardly won pre-eminence as the leading tragedian of the day. Even the most determined opponents at length yiclded up their prejudices to the public verdict. During his long practice of twenty-eight years, he now for the first time stood before lis judges in an original part of first-rate importance. The play has acquired a celcbrity from his representation of the principal character, which calls upon us to dwell a little on the work and the writer.

"Louis the Eleventh" was produced at the Théâtre Français, in Paris, as far back as February, 1832, and by many Frencl critics was held to be the masterpiece of its author. Casimir De La Vigne, it will be remembered, died towards the end of the year $18+3$, aged only forty-nine. He was a prolific writer, and one of the most popular of the modern poets of his country. Noble and inspiring sentiments are embodied in his 
verses; his characters, particularly when taken from history, are drawn with fidelity, severe truth, individual precision, and graphic distinctness. He never alters a portrait, which flattery might soften and render more agreeable by keeping in the background, or subduing altogether, prominent but repulsive features; and he seldom suffers himself to be seduced into the substitution of mere grace and elegance in place of the vigorous thought and strong sentiment which, though less pleasing and attractive, are better calculated to leave a lasting impression on the mind. In more than one respect, he is worthy of a comparison with Corneille. He has the same clear, consecutive reasoning, and a fair portion of the similarly remarkable faculty of condensing much meaning into a small compass. Why a dramatist possessed of this ability, and enjoying such an exalted reputation in his own country, should not have been more frequently introduced to the London boards, is a question which naturally occurs, and may be answered by a reference to the many obvious points of distinction in national taste, and to the various experiments by which it has been proved, that because a given play has met with great success in Paris, it by no means follows, as a eorollary, that it must have the same good fortune in Iondon. Contrary instances are ready in abundance.

English managers, on the other hand, are often accused of want of patriotisn, or of defective judgment, in running too readily to the foreign market for the supply which may be found, of a superior quality, and to any extent, at home. A glance at the res gesta of the lcading London theatres for the last three or four years, or any other selected period, will show that much of this charge is unjust- - that indigenous talent has not been set aside unfairly or indiscriminately - that original authors have not been too modest to ask, or managers too niggardly 
to give, large sums for original plays. But the public are capricious, and do not always accept the bill thus drawn and endorsed; in which case, the contracting party who buys is in an infinitely worse predicament than he who sclls. The former has probably paid something considerably over the usual price for what comes recommended under an established name, which looks imposing in an announcement, but in a commercial sense often turns out to be an empty myth. After one or two failures at home, success steps in from abroad. In fact, the French beat us systematically, in plot, construction, and what is universally understood by the term coups de théatre-dramatic effects. One English writer may be an imaginative poet; another, a stern moralizer; a third, rich in epigram and satire; a fourth, an able sketcher of character; a fifth, a racy humourist, and so on. But all these qualities count for little unless they are united with a knowledge or perception of practical effect. We do not mean such mechanical contrivances as a trapdoor or a sliding panel, a ghost or a demon, surrounded by blue or red fire, in every scene. The ingredients we consider as indispensably requisite, are passion, action, and varied incident. In the dramatic derelopment of these agencies, our continental neighbours generally leave us behind them.

The French poct has worked the pith of his play almost entirely into the single character of the King. Whether this plan of a grand historical drama is sound in principle, is a question open to critical inquiry, on which very opposite opinions may be delivered; but that it demands from the actor who is called upon to embody such a conception of his author, a gigantic combination of mental and physical attributes, is an evident fact, which establishes itself without argument. Louis XI. was essentially a wicked and re- 
morseless tyrant. His reign presents a complicated tissue of crime and hypocrisy, unvaried by a single act of mercy, a solitary impulse of affection, or an exceptional aceess of human feeling. He lived in terror, and died in despair. There is an awful lesson to be extracted from the terrible events included within the sixty years of his existence on earth, and during one third of which he was permitted to scourge his fellow-men by the exercise of unlimited power. Louis, as presented in Casimir De La Vigne's play, is drawn exclusively from history. No heightened colouring is superadded from poetry or imagination. The novelist here is not suffered to distort the true character of the monarch. Cominès has depicted him with rather a lenient hand. He forgot, or pardoned, the outrage which obtained for him the cognomen of tête bottée. Other authorities have been less warped or delicate, and all the hideous features of his character are so familiar by description, that when reading of him, we feel the presence of the demon-man in terrible reality. In Sir Walter Scott's romance of "Quentin Durward,". he is pleasant, sometimes almost amiable, and exhibits human sympathy in two or three instances. In the hands of the French dramatist, he never unbends, never relaxes for a moment from his constitutional hypocrisy, his bigotted superstition, his bloodthirsty tyranny, his doubts of cvery one, and his overwhelming dread of death and futurity. Iouis of Valois was not naturally a coward, for he had given proofs, at least of passive valour, when he fought at Mont L'Hery; of cool self-possession, when he voluntarily placed himself in the power of Charles of Burgundy, at Peronne; and of confidence in his personal resources, when he cajoled Edward IV. of England, at Amiens, and tumed aside by agile diplomacy the most dangerous invasion that had threatened France since the days of Cressy, Poictiers, 
and Agincourt. The whole character, like Richard of Gloucester, his contemporary, is a compound of opposites and antitheses. He was, at the same time, trustful and suspicious, hoarding and wasteful, audacious and timid, mild of bearing and given to unbridled bursts of passion, soft of speech and relentless of heart; a violator of every oath he pledged, a breaker of every treaty to which he subscribed his name; a scoffer at religion, while he bent in terror before leaden images of saints; and to wind up all, the first French monarch who bore the title, long continued by his succesors, of "the most Christian King."

To reconcile the play as much as possible to the classical unities, which are still reverenced in France, when what is understood by the "regular drama" is concerned, M. De La Vigne has crowded together incidents which took place at long intervals, and ends with the death of Louis, represented as immediately following that of Charles the Bold, although seven years actually interposed between the two events. The sequence of incidents is most ingeniously contrived, and except to a rigid chronologist, the anachronisms are imperceptible, and may be excused. The careless spectator, who sits to be entertained, without deep research, will not readily detect where the true chain of history is broken, and reality superseded by fiction. The characters include Philip de Comines, the pliant biographer; Tristan l'Hermite, the formidable provost-marshal; Olivier le Dain, the barber-minister; the amiable Dauplin, afterwards, and but for a short reign, Charles IX.; and the devout ascetic, François de Paule, who practised in his own person the severe self-denial he recommended to others. There are also Jacques Coitier, the king's physician, who holds his life in his hands, the only living being he dare not do without, lest he should die 
for lack of help in his disease and guilt; and Marie, the gentle daughter of Comines; and the fiery Nemours, her betrothed lover, thirsting for the blood of his father's murderer, and ready to lay down youth, life, love, and ambition, on the altar of the Moloch of revenge. These, with a group of peasants, compelled to act joy while quaking with terror, make up the list of characters.

The English adaptation, which is skilfully managed, and conveyed in easy, flowing language, follows the original with accuracy, differing only in one material point at its termination. In the French play, the pardon of Nemours arrives too late. He is executed; and thus the crimes of Louis receive a posthumous addition, as his solitary act of penitence is too tardy to be availing. In stern moral and poetical justice, as regards the arch criminal, the catastrophe may be justified; but as a question of which leaves the most satisfactory impression on the audience, public opinion was decidedly in favour of the change.

Of the effect produced by Mr. Kean in the character of Louis the Eleventh, it is more than difficult to convey an adequate description. We do not recollect anything to compare with it in recent times; nor can we name any theatrical performance, it has ever been our fortune to witness, so totally free from blemish or objection; sustained with such uniform power, relieved by so much variety, and altogether presented to the judgment of the public as a picture of such brilliant colouring and masterly filling up in all its different shades. Many lingering and obstinate cavillers were totally converted by this great achievement. The enthusiastic feeling of the house on the first night reminded us of the excitement we had witnessed during the best days of his father's Othello. Even when the play was over, and he lay dead before the audience, they trembled lest he 
should start up again, and work fresh mischief with the revivified influence of a ghoul or a vampire. Mr. Kean is not, in "Louis the Eleventh," as in the "Wife's Secret," supported by his accomplished partner, in a part of dramatic strength and interest superior to his own. The play wants the controlling charm which attaches to a prominent heroine. There is nothing here to assist the single actor; he must create his levers for himself. The character of Louis is so far beyond sympathy, so utterly repulsive, that in the hands of a coarse or clumsy artist, it would be unendurable. The secret of the true effect lies in the relief and variety; and the knowledge of these grand arcana marks the distinction between mediocrity and excellence. Herein lie the mystery and mastery of genius, whether exemplified by the painter, the poet, or the actor; and in the management of these resources, always thrown in at the critical moment, and in the right place, as a skilful general arranges his reserves, Mr. C. Kean carried his audience completely along with him, and swept away objections which a monotonous manner would have rendered fatal. The character, as he wielded it, became as plastic as the clay in the hands of the modeller, and, with every slight movement, presented a new feature. Looking to the past, we cannot readily select any actor of former days who could have competed with the living representative. Great requisites they had, but seldom or never so many combined-the quick, piercing eye, the flexible intonation, the expressive features, the compact, manageable figure; the rapid action; the varying conception; and the same extraordinary facility of depicting the wcakness of age, the exhaustion of physical pain, and the gradual approaches of death. On this occasion the press echoed the decision of the public, with scarcely a dissentient voicc. "Louis the 
Eleventh" was acted for sixty-two nights during the first season of its production, and has ever since continued one of the most attractive plays on the permanent list. Mr. Kean received many congratulatory letters, written by judges whose testimony was valuable, and from which the following are selected, without order of date:-

\section{From Colonel the Hon. Sir Charles Phipps, K.C.B.}

"Buckingham Palace, "Feb. 20th, 1855.

\section{"Mr dear Kean,-}

"I wished very much to have seen you last night, but I could not leave my two young ladies without a chaperon. I wished to have told you, whilst my admiration was boiling, how admirable I thought your personification of Louis the Eleventh. I consider it the finest piece of acting that $I$ have seen in my experience. I can understand the possibility of the passionate scenes being equalled perhaps, magnificent as they are. But the way in which you managed to identify your mind with the double character you had to portray, is to me an excellence in art which is wonderful. There appeared to be no. look, no gesture, no tone of voice, that was not that of a cruel, cowardly old man. Any one who knows you in private life must feel how much of art there must be in this. You have known me often a sincere critic; you will, I am sure, believe in the truth of my admiration. If I had time I would go much into detail upon this piece of acting, which kept my cheeks burning with excitement, whilst my lower man was, like the King's, in the 'Arabian Nights', marble from the cold.

"I may tell you that the opinion of your performance is equally high upon the part of my royal mistress and 
master. Remember me kindly to Mrs. Kean. I hope she keeps well.

$$
\begin{aligned}
& \text { "Sincerely yours, } \\
& \text { "C. B. PнIPPs." }
\end{aligned}
$$

From Samuel Warkex, M.P.

“ 35, Woburn Place, Russell Square, " 19th January, 1855.

\section{- My dear Sir,-}

"Permit me to thank you cordially for the unbounded delight which you afforded all my family last night, by your splendid representation of Louis the Eleventh. They hardly know how to express themselves, such is the sort of infatuation with which you have filled them; and they will not hear of my returning to chambers this morning before I write to say how greatly they are obliged to you...... This is Term-time, and my evenings are uncertain; but it shall go hard if I do not, in a day or two, find myself in the stalls. I am most impatient to go; and to such a piece as that of last night, infinitely prefer going alone.

"I hope you will allow me to present you and Mrs. Kean with a copy of the new edition of "Ten Thousand a Year," which I have rigorously revised timroughout.

$$
\begin{aligned}
& \text { "I am, my dear Sir, } \\
& \text { "Yours, very much obliged, } \\
& \text { "SAMUEL WARnes." }
\end{aligned}
$$

"Sir F. Thesiger and his family were there last night."

"MY DEAR Sir,-

“ Jan. 23d, 1555.

"I return you a thousand thanks for one of the greatest entertainments I have (as an old actor) experienced for years. The best opinion I can give of 
your performance of Louis the Eleventh, is to reiterate the criticisms of my friend the Critic. Wishing you many years of health to repeat such representations, I have much pleasure in signing myself

$$
\begin{aligned}
& \text { "Your sincere admirer, } \\
& \text { "William FarRen." }
\end{aligned}
$$

\section{From Miss Isabella GlynN.}

"Mr DEAR SiR,一

: 13, Brook Street,"Grosvenor Square.

"Indeed I highly value your kindness in affording me the opportunity of witnessing your rare performances as often as I can. Work will soon preclude me from that enjoyment very often, so I at once avail myself of your generosity and ask for a box for next Friday. If last Friday was not one of your grandest nights, what then must you be when self-pleased! You were great. We all felt very distressed about that noise, for I know how deeply hurt you would be by it; but you soon lost us to all but your wonderful powers. I have not a doubt but that the seeming coldness of the audience arose from an inability to applaud you. Your intensity is really terrible. I felt white with excitement, and caught myself holding by the chairs, grasping tightly for comfort, for I could scarcely breathe, and could not applaud until I was enough recovered to remember you were acting. I could write pages on every part of your great work. But your entire dying scene, how true and affecting it was. That crawling to the crown with no physical power, but with a deadly yet real cnergy, makes my flesh creep now only to think of it. I am reluctant not to dwell on this longer, but must cease to intrude upon your valuable time, and patience too, as I fear I do. "Yours, very obliged and admiringly,

"Isabella Glynn." 


\section{From Mrs. HowitT.}

"The Hermitage, Highgate Rise, "Jan. 23rd.

\section{"My dear Mr. Kean, -}

"You are quite prepared, I am sure, to hear that we were delighted, last night, by your new character, for you must yourself be aware of its extraordinary power and elaboration. We were astonisled, for it exceeded our expectations, and we expected a great treat. It was unquestionably one of the most wonderfully conceived impersonations that was ever given. There is no halting in it, it falls short in no way of the perfection of nature, and one's very blood runs cold at the realized villainy, hypocrisy, and cowardice of the character. It is a master-piece in your hands, and we congratulate you not only on your success, but on the possession of such creative power.

"We longed to say as much to you last night, and to have shaken hands with Mrs. Kean, whom we saw on the other side of the theatre, but she was not in her box between the acts, nor after the play, and we would not miss a single word. However, receive our thanks for a very great pleasure, and with our united regards to you both,

$$
\begin{aligned}
& \text { "Believe me, my dear Sir, } \\
& \text { "Yours sincerely, } \\
& \text { "MAary HowitT." }
\end{aligned}
$$

\section{From Sayuel Lover, Esq.}

“ 43, Denbigh Street, Warwick Square

\section{"Mry Dear Kean,-}

$$
\text { " 2.5th Jan., } 1555 .
$$

"Though you must by this time be almost weary of laudation of your Louis the Eleventh, I cannot resist the 
pleasure of thanking you for the intellectual enjoyment your performance of Saturday last afforded me. In conception most artistic; in execution masterly. May many more such triumphs lie before you.

\section{"Yours faithfully, "SAMUel Lover."}

\section{From J. Palgrave Simpson, Esq.}

" 9, Alfred Place West, Thurlow Square, Brompton, "15th Jan., 1855.

\section{"Mr dear Mrs. Kean,-}

"I called at your house yesterday in the hope of seeing you, but to my disappointment I heard that you were all gone out. Perhaps I ought not, however, to say ' disappointment,' since the fact convinced me that Mr. Kean was not so much exhausted as I feared he would have been from his tremendous exertions the previous day. Pray present him, what I could not give by word of mouth, my heartfelt congratulations upon the triumph he has achieved. I am pleased to find that such papers as $I$ have seen, coincide entirely with me in the sentiment that his performance was one of the greatest histrionic displays ever witnessed on the English stage. I myself am enthusiastic about him. I have scarcely yet recovered from my state of over-excitement and the intensity of emotion which the performance produced upon me. You know my extreme fondness for the stage, and you may guess with what gratification I witnessed acting in which it is impossible to find one movement that does not completely sympathise with one's own feelings; impossible to see. anything but perfection. I wish my opinion could be worth, in your eyes, what that of many better and higher men must be, that I might give my return to Mr. Kean for the great, great gratification he has afforded 
me. One reason for my wishing to see you was, to ask whether you or Mr. Kean had any commands for Paris, for which place I start to-morrow evening, per mail train. If I can do anything, will you please let me know. ...... With kind regards to Mr. Kean and every wish for your joint success and prosperity,

"Yours very sincerely,

"J. Palgrave Simpsos."

The success of "Louis the Eleventh" established a decisive period in Mr. C. Kean's career as an actor. It was also remarkable for the winding up of a determined opposition, which had hitherto accompanied every new play produced under his management. A small knot of enemies congregated together on all these occasions, and took post in different parts of the theatre, acting by signals under preconcerted arrangement. Whenever the great majority of the house applauded, they intermingled the note of disapprobation, and frequently marred the effect of the most telling passages by premeditated noises, so ingeniously contrived as to appear accidental. The finest points of the finest acting may be destroyed by a congh or a snceze, thrown in at the exact moment, as effectually as by the virulent hiss, which cannot always be ventured with equal safety. During the rm of "Richard the Third," the practice was so apparent, and so evidently against the feeling of the audience, that Mr. Kean, accompanied by his acting manager, waited on Sir R. Birnie, with a view to the adoption of protective measures. The police officers on duty in the theatre, declared their convietion that a conspiracy undoubtedly existed, but so organized that they were unable to deteet it. When the individnals thus engaged felt that they were under survillance or hat become obnoxious to the public senerally, they never snowed 
front, but immediately left the theatre or remained silent for the rest of the evening. After the second or third repetition of "Louis the Eleventh" they finally disappeared, either from exhausted funds or in despair of carrying their object. These matters may appear unintelligible to those who have never had occasion to fathom the full extent of personal pique or jealousy. In the present instance,

"Imputation and strong circumstance Which lead to the door of truth,"

point to the suspected parties; but in the absence of positive proof we abstain from the most remote inference. They know themselves, and may be assured that they are known. The remark can offend none but those who are conscious of its application. "Qui capit, ille facit." 


\section{CHAPTER VII.}

A GAME OF ROMPS-THE MULETEER OF TOLEDO-HOW STOUT YOU'RE GETTING-REVIVAL OF SHAKESPEARE'S KING HENKY THE EIGHTH, AND RETURN OF YRS. C. KEAN TO THE STAGE-CRITICAL REMARKS ON THE PLAY AND PERFORMIXCE-MR. C. KEAN'S CARDINAL WOLSEY ; MRS. C. KEAN'S QUEEN KATHARINE-UNPRECEDENTED ATTRACTION, AND RUN OF ONE HUNDRED COXSECUTIVE NIGHTS-ACTING SUPERIOR TO PAGEANTRY -PUBLICATION OF HEXRY THE EIGHTH, WITH PREFACE AND YOTES-RESTORED SCENES AND NEW STAGE ARRANGEMENTS-CONDENSATION OF THE FIFTH ACT-EXD OF THE SEASON-DIFFICULTIES SURXOUNTEDCONCLUDING REFLECTIONS AND GENERAL SUMMLAR.

Subsequextly to the production of "Louis the Eleventh," three light pieces were brought forward at the Princess's, during the season of 18545 , from the pen of Mr. J. M. Morton, author in ordinary to the establishment. "A Game of Romps," the "MIuleteer of Toledo," and "How Stout You're Getting," were all of French origin, freely adapted, and met with the usual ephemeral success. Why does not this easy, agreeable writer extend his ambition, trust more to his own resources, invoke the spirit of his father, and try his hand at an original comedy? We have had none that bids for immortality since Sir Bulwer Lytton's "Money." The field is still open and productive; a rich harvest might yet be gathered by followers of the

* The title and subject of this fine play are, and ever will he, universally applicable ; and must ensure enduring popularity, despite the fluctuating caprices of fashion, while the wit of Congreve and sheridan is remembered, and ther laugnage spoken. 
same school. "A Game of Romps," the first of the three trifles alluded to above, came out on the 12th of Mareh. The French piece from which it is taken bears the title of "Les Jeux Innocents." It was a mere sketch, with little or no plot, deriving attraction almost exelusively from the personal charms of the ladies included in the east, and the humour of Harley, who played a sort of French Dominie Sampson, in which he was measured to the life. The piece altogether was an improvement on the original. In Paris there were some amongst the bevy of intended graces the very opposite of attractive. At the Princess's they were, without exception, dangerously beautiful. These short, one-act introductions, so much in fashion in the present day, are very available for the purpose of playing in the audience, and setting them in good humour for the more important business that is to follow. They are built exclusively on smart dialogue, quick repartce, and comic situation. From these ingredients a preliminary halfhour of exeiting merriment is often gained, particularly if there is no studied determination to be funny, the transparent labour of which clogs and defeats the most zealous aspirations of humorous writers and their exponents. A spectator or listener never thoroughlyenjoys a joke unless he feels it to be spontaneous, natural, arising from the circumstances of the case, and born of itself. Then he laughs heartily, and, having got into the true vein, seldom pulls up until his gallop is exhausted. But if he pereeives that the author and actors are flagging, or exhausting themselves in painful attempts to produce hilarity, not to be extracted from the materials with which they are working, he soon becomes inoculated with their heaviness, and his mirth evaporates in a yawn. "A Game of Romps" was entirely divested of this damaging characteristic. 
The "Muleteer of 'Toledo," designated in the bills as a "romance" in two acts, was selected for the Easter novelty.* In its original form as an opera, much of the action was carried on through the medium of $\mathbf{M}$. Adolphe Adam's popular music. In the English alteration we had humour for melody, and smart epigrammatic dialogue in place of long-concerted pieces and interminable finales, in which the words, supposed and intended to be interpreters of the sense, are too often smothered up in lyrical evolutions, revolutions, inflexions, and variations. Whether this change is an improvement forms a question for a critical jury; but if they were empanelled from an Easter Monday audience, there can be little doubt that the verdict would be unanimous in favour of the laugh. During that season of merriment a joke would carry the day against a bravura, without hesitation.

"How Stout You're Getting" turns entirely on the distress of a fat little gentleman, Mr. Plummy, a chemist and druggist, who has no idea that he is becoming corpulent, until constantly reminded by his wife and others that he expands daily in circumference and weight, as a natural consequence of indolent and gormandising habits. Mr. D. Fisher, as Plummy, deserved the highest praise, not only for his humour but for the physical exhaustion he so loyally sustained-no trivial matter in the dog days, with the thermometer at $90^{\circ}$. To combine the bulk of an incipient Falstaff with the agility of Marlequin is more easily conceived than executed.

A combination of two important events in Mr. C.

* The same subject has since acquired additional reputation with Balfe's music, as the " Rose of Castile," so successfully produced by the English Operitic Company under the management of Miss Pyne and Ir. Harrisoll. 
Kean's individual management, and in general theatrical history, occurred on Wednesday evening, the 16th of May, 1855, by the production of Shakespeare's "King Henry the Eighth," and the re-appearance of Mrs. C. Kean, after a long secession of nearly a year and a half, occasioned through severe and constantly recurring illness. It had been currently reported and believed that she had retired altogether into private life. 'The rumour gained strength with time, and anxiety increased as months rolled by and no announcement appeared of the return of the highly gifted lady whose absence was so severely felt. The apprehension of her loss was also augmented by the conviction that no rising star had given evidence of power, either present or prospective, to fill the much regretted vacancy. The recent recruits were not of a standard to justify their being placed in the front rank. There might be some promising candidates ready for judgment, but as yet they were unenlisted. Every great artist is looked upon as public property, and all members of society are jealous of their share in what they regard as common right. When Garrick went to Italy, a young performer named Powell sprang up unexpectedly, and stopped the gap with so much success, that Lacy wrote to his partner, telling him there was not the least occasion to hurry himself or abridge his intended tour. This intelligence brought the apprehensive Roscius back at double speed, trembling lest his laurels should be in danger. When Garrick retired, Henderson and Joln Kemble stepped forward, well trained and gifted, to compete for the vacant throne. When Kemble's hour of repose arrived, there were Young, who had long reflected his style, and Edmund Kean, who had converted half its worshippers. As Mrs. Cibber, Mrs. Pritchard, Mrs. Barry, and Mrs. Yates successively waned, Mrs. Siddons rose in her meridian 
splendour, and eclipsed them all. When she too withdrew, there was Miss O'Neill ready to step into her place. We could not point to any living luminary likely to console us for the loss of Mrs. Charles Kean. In addition to her acknowledged professional supremacy, a warmth of regard and respect attaches to her personal character, which gave to the enthusiastic plaudits that resounded through the house as she entered, and were long continued, the appearance rather of the greetings of private friends than the mere delight expressed by a promiscuous audience at once more seeing before them, restored to health and in full possession of her powers, one of the brightest omaments that has ever graced the theatrical profession. With her return, the Princess's Theatre recovered the full lustre which her long absence had somewhat eclipsed, while the drama in general regained a most important pillar of strength.

Much diversity of opinion has been indulged in by learned commentators as to the merit of "King Henry the Eighth" in comparison with the rest of Shakespeare's historical plays. Many consider it the best, as it is the last, and most carefully constructed, both in regard to the facts introduced, and the powerful contrast with which the leading characters are opposed to each other. The age was one of unparalleled magnificence-a taste fied and encouraged by the personal habits of the two monarehs of France and England. The latter nation in particular, then as now, richer than its neighbours, spared no expense in shows, entertainments, and apparel. I nobleman of that day carried half a year's revenue on his back whenever he appeared in full state. We are greatly advanced in our notions and praetice of domestic comfort, elegance, and convenience, but we cannot rival our ancestors in ontward display. In festivals and banquets, too, they vied with royalty itself, and were as 
lavish as Apicius, who eommitted suicide after the high Roman fashion, when his steward arnounced to him that the cash in his strong box was reduced to 250,000 erowns, sufficient in his estimation for only one supper more.

If there is less of stirring action, of the din and vicissitude of war, of hero painting and ambitious rivalries, of plots, conspiracies, rebellions, conquests, and political reverses in "Henry the Eighth," than in the plays illustrating earlier and more unsettled reigns, there is a much greater infusion of pomp and pageantry, an increased gorgeousness of detail, mingled with passages of exquisitely imaginative poetry, which compete with any that have proceeded from the same magic pen. The two most prominent characters, the Queen and the Cardinal, require powers of the very highest order, mental rather than physical, and ean only be rendered truthful and effective in proportion as the representatives throw aside stage conventionalitics or hereditary adoption, and study them from the features so minutely delineated in the histories and chronicles from whence. Shakespeare derived the sources of his own inspiration. Many of the most important scenes are so faithfully rendered, that the substance and even the words of the dialogue are not altered, but merely heightened by the glowing genius of the poet into harmonious verse. The defect of the play lies in the anti-climax at the end, the total cessation of interest in the fifth act. After the fall of Wolsey and the death of Queen Katharine, the action ceases. And yet to drop the curtain on the latter incident had always been found somewhat incomplete when the experiment was tried. 'Then, again, the long and disconnected introduction of the scenes in which Cranmer is concerned was pronounced also to be insufferably wearisome. We take no interest in a sub- 
ordinate character we have not seen before, and who is brought in at the fag end to supply the place of the more attractive principals who have vanished from the scene. However venerable in history, the illustrious archbishop is not entertaining on the stage. We remember well the yawns and lassitude of the audiences in the days of the Kembles, throughont this interminable episode, from which not even the traditional buffooncries of Bishop Gardiner in lis forced reconciliation with the Primate, or the following glories of the christening, could effectnally revive them.

In the arrangement of "Henry the Eighth," which embraces a period of twelve years, Shakespeare has indulged in two or three deviations from chronology, for which he has been loudly condemned. The most important of these is placing the death of Queen Katharine before the birth and christening of the Princess Elizabeth. He did this, not from ignorance or carelessness, as ready censurers have supposed, but to wind up his play more agreeably than if he had closed with a tragic incident; and to introduce a panegyric on the reigning queen, under whose patronage he wrote, and who was, if possible, more punctilious in her extreme old age, more exacting in obsequious homage, and more swayed by Hattery, than she had been in the meriaian of her power and womanhood. The poet had another delicate task to accomplish in the delincation of IIenry the Eighth himself. It was necessary to render him respectable at !east, if not amiable, and neither point would be attained withont stecring far beyond the latitude of truth. Shakespeare, however, compromised the difficulty with tolerable success, by selecting a portion of the sensual tyrant's life the least open to broad objection.

If, five years carlier, Mr. C. Kean had said to any given circle of listeners, "I will bring out a play of 
Shakespeare, and one not hitherto generally popular, and I will run that play one hundred nights to crowded houses," the company present would have smiled in unanimous unbelief, and would have answered (or, if courtesy chained their tongues, they would have uttered in thought ), "The thing is an empty chimera, and the enthusiast who dreams of it as a practical reality, is a candidate for Hanwell or St. Luke's. How is it possible that you, a degenerate modern, should fancy you can accomplish what Garrick and the Kembles never thought of undertaking? And with Shakespeare, too, who is obsolete and out of fashion, unsuited to the taste of the day! A text book, if you like, but one seldom opened except as a reference, to settle a dispute, or verify a quotation."

Well, the experiment was tried, and succeeded. The attempt and completion became realized facts, to be quoted by future generations, in writing or speaking of the stage, as one of the most marvellous incidents connected with the subject on which they dilate;--a landmark in dramatic chronology. A Shakespearean play did run for one hundred consecutive nights, with the exception only of Mr. and Mrs. C. Kean's benefit, when a change of performance was substituted as a compliment to their immediate patrons and friends. The nearest approach to this great attraction occurred in the instance of " Macbeth," at this same theatre in 1853, and when Miss Fanny Kemble came to the rescue of Covent Garden in the season of $1829-30$, on which occasion "Romeo and Juliet" produced upwards of forty attractive repetitions. It could not be the pageantry, the procession, the banquet, or the scenery, that achieved this great triumph ; as much, and even more, of all those embellishments, and at a greater cost, had been bestowed on the same subject at earlier revivals. Before, and during 
the period of Garrick's management, "Henry the Eighth" was on the acting list, and selected as a vehicle for costly expenditure seldom reimbursed. We read of its running twenty nights at Drury Lane, in the early part of 1728 , to houses which scarcely paid the expense, and were principally attracted by the magnificence of a coronation, introduced as a fac-simile of that of George II., who had just ascended the throne. Booth acted the King, which in those days was considered the principal part, and Colley Cibber was the Wolsey-a character for which he had no single requisite. 1,000l. was expended on the coronation scene alone-a very large sum more than a century ago. But what was this, or any recent outlay, compared to the $100,000 l$., which the Athenians are said to have lavished on a single tragedy of Euripides? "Henry the Eighth" was also a favourite play during the reign of the Kembles. The writer of these pages, in conversation with Charles Kemble on this particular subject, has more than once been told by him that it was the most costly and least remunerative of all the great revivals under his brother's siperintendence. What, then, could have produced the superior attraction in 1855? Assuredly not the expenditure and show, for they had been equalled, if not surpassed, before. Let us deal justly, and say, it must have been the extraordinary combination of all the highest elements of art, until then, neither sought for nor employed with the same happy discrimination. The result belongs to the life-painting, the virid resurrection of persons, places, and events - the severe, undeviating accuracy of historic research, rather than to dumb pictorial accompaniments, however appropriate and imposing, or to new mechanical appliances, with all their marrellous ingenuity. The acting is the oil that feeds the lamp, and without that rich pabulum in ample supply, the light would soon firn into "dar'innse ricible." 
In a single season the characters of Wolsey and Queen Katharine were played by Mr. and Mrs. C. Kean oftener than by their greatest predecessors during a career of thirty years. This was a fact which the most resolute detractors were unable to dispute, although pertinacious in spirit, while few in number, and clinging to their own notions with the dogged obstinacy of prejudice, determined to be wrong. From this time forward they slackened and declined. Mr. Kean had now so firmly established his position, had won such golden opinions from an overwhelming majority, that he had no occasion to heed a few dissentient voices, which finally lost themselves in their own clamour.

The usual "fly-leaf" with which Mr. C. Kean had accompanied his earlier Shakespearean restorations was affixed to the bills of "Henry the Eighth;" but this time both play and preface escaped burlesque. Either the usual indulgers of that practice were consciencestricken, or the vulgar resource had lost its popularity. With reference to his alterations, Mr. Kean said: "In the revival of 'Henry the Eighth,' it will be perceived that $I$ have ventured to differ from the stage arrangements of my predecessors. Although in their time fine scenic effects were produced, and much pageantry was displayed, the management did not attempt, nor did the public require, that scrupulous adherence to historical truth in costume, architecture, and the multiplied details of action, which modern taste demands, and is so capable of appreciating, when employed in the service of the monarch of dramatic poetry." The notice wound up with the following sentence:- "I cannot conclude without an allusion to Mrs. Charles Kean's return to the stage, after a long secession, occasioned by severe illness. It is only thus that I can record my appreciation of the compliment she has received in the voluntary proposal 
of the ladies of the company, not representing charaeters in the play, to appear as her 'Ladies in Waiting.' Such an offer is the more valuable, as it combines a graceful expression of personal esteem with a zealous desire to uphold the interests of the theatre."

The revival of "Henry the Eighth" was accompanied by a printed edition of the plan as then acted, with historical and explanatory notes by Mr. C. Kean. The books were sold in the theatre alone, for the exclusive accommodation of its frequenters, and above 6,000 copies were thus circulated. The plan has since been continued with all the subsequent Shakespearean restorations, in an unbroken series. These plays, in a collected form, are now in course of publication by Messrs. Bradbury and Evans. They are highly valuable in a literary sense, and may be strongly recommended as eligible studies for the more youthful readers of the dramatic master; the text being carefully preserved, and assiduously purified from all objectionable passages or expressions.

The new acting version of "Ilenry the Eighth" must be considered here with regard to its fitness for representation. It was not ventured as a critical liberty, or an ambitious experiment to improve Shakespeare as he wrote; but as a zealous effort to place the poet on the stage for which he composed, to the best advantage, and with the reality which he conceived and intended, although without a hope of seeing the accomplishment with his own cyes. In doing this, it is equally permissible as necessary to curtail or restore; while true taste slurinks from any attempt to alter or amend with arbitrary judgment, too often regulated by caprice or biassed perception. Mr. C. Kean cannot be too much commended for the care with which he has preserved the ginuine text of Shakespeare, as well as for the re-intrn- 
duction of some noble passages, to the exclusion of others of infinitely less beauty and importance. The notes bespeak depth of research, and the scrupulous regard for truth by which even the most trifling improvement was held in abeyance, until supported by unquestionable authority. No names are assigned without a stated reason, and characters are no longer blended for stage convenience (such, for instance, as Cromwell and Griffith), which Shakespeare, following history, liad distinctly separated. The error has been too often indulged by managers of high pretensions in earlier days, when a punctilious observance of all these details was less imperative than modern taste requires, and values in proportion. A printed book of Mr. C. Kean's "Henry the Eighth" was absolutely called for to convey the full account of all the startling novelties that were introduced into this fine drama. As everybody went to see it acted, so almost every one who could command a spare shilling purchased a book, that he might recall at his ease, in his arm-chair, the succession of dazzling scenes which had so enchanted his faculties in the theatre. Many persons have a passion for reading while they are assisting (as the French say) at the performance. We have no right to quarrel with individual taste, but we cannot commend this habit, except in the case of an Italian opera, or a performance in French or German, where the difficulty of following the foreign idiom often demands reference to a present interpreter. A dramatic representation is intended to strike directly through the medium of the eye; but if the eye is constantly wandering to a page, more than half the effect is lost. The reader who is looking on his book instead of on the stage, may occasionally find that an actor has tripped in the text, or detect him in substituting and for but. He has made a point 
against him, as a critic, it is true ; but he loses in intellectuai enjoyment much more than he can possibly gain by the discovery of an unimportant fact. The appearance of a line of students, too, operates as an embarrassing. check on the energies of the performer. We have seen Othello sink suddenly from the height of frenzied . passion to dead apathy, when his eye fell by accident on the apparition of a grave, spectacled, elderiy gentleman in the stage box, pouring over his text-book as immovably and solemnly as if he were spelling a mystified leader, or a long parliamentary debate in one of the morning papers. We therefore recommend it as a much more wholesome canon, to purchase a book by all means, but after you have witnessed the performance, and to read it carefully while at breakfast on the following day.

We are somewhat surprised to find Hazlitt, who has been often quoted as an acute Shakespearean critic, expressing himself as follows:- "The representing the very finest of Shakespeare's plays on the stage, even by the best actors, is, we apprehend, an abuse of the genius of the poet. Shakespeare has embodied his characters so very distinctly, that he stands in no need of the actor's assistance to make them more distinct." It is not very easy to understand these sentences, or to follow their meaning with satisfaction; but we suppose they are intended to convey that Shakespeare's plays are weakened by being acted, and ought to be entirely reserved for the closet;-a startling position, which would astonish Shakespeare not a little if he conld be made aware of it. As he undoubtedly wrote his plays to be acted before they were read (many of them were not printed at all during his life), for the stage in preference to the library, we may take it for granted that he knew what he meant and intended, and how to construct his own conceptions for his own selected purpose. But VOL. I!. 
these subtle commentators would fain persuade us that they are more deeply in his confidence than he was himself, and can interpret the workings of his mind with more fidelity than he has exhibited them.

The same materials from which Mr. C. Kean so laboriously studied and selected in his Shakespearean revivals were available to his predecessors. The same, authorities were open to their research, and yet they disregarded, or, having casually looked into them, passed them over as of no moment. It is true that such minute historical accuracy was not then expected. General knowledge was more limited. The taste of the day satisfied itself with a bold outline, a striking feature in a few prominent situations, instead of a portrait complete in all its details. If, occasionally, a great scenic display was presented, it stood by itself; there was no attempt to carry a series of corresponding efforts throughout an entire performance. Mrr. Kean is the first manager who has understood and accomplished this perfect colierence. Former generations saw "Henry the Eighth" represented with certain insulated effects, - such, for instance, as the coronation of Anne Boleyn, and the christening of her infant daughter; but they never witnessed the whole play illustrated, as now, by a succession of historical pictures, in which every person, group, and movement is modelled from life; not taken from imagination or poetical resemblance, but embodied from the minute descriptions of those who had seen, known, and lived with the characters introduced: with whom they were as familiarly acquainted as with the places they inhabited and the costumes they wore. The order of Wolsey's march as he is passing to the council chamber, the dazzling splendour of the banquet at York Place, the solemnity of the execution - Buckingham, the distribution of the court for the 
trial of the divoree question between the King and Katharine of Arragon, the etherial beauty of the vision in the scene of her dream and deatlı; and above all, the introduction of the highly characteristic interview between the two cajoling cardinals and their persecuted victim;-these bold and truthful innovations are exclusively the result of Mr. Kean's close examination of his subject, and are as entirely new as they are superior in value and reality to the old conventional arrangements they have so happily superseded. It is by the independent exercise of its own strength that true talent bursts from the fetters of habit and traditional routine, finding variety and power in its own innate resources.

The old mode of disposing the trial scene is perpetuated in Harlowe's celebrated picture, usually called the Kemble Family, from the number of portraits it contains of that distinguished race. The painting, we belicve, has disappeared mysteriously, but the engravings are numerous and familiar. There we see the King seated on his throne in presiding dignity, and the two cardinals at the table, mixed up with the other members of council. There is nothing to mark the ecclesiastical supremacy with which the court was invested. The Queen stands majestically in the front. We look on an imposing group, picturesque and poetical, but conveying no true reflection of the event as it occurred. According to Mr. Kean's disposition of the stage, the two cardinals, who are appointed under a special commission from Rome to try the case, are scated together on an elevated platform. The great churchmen and lawyers occupy their appointed stalls. The King: as plaintiff in the cause, sits on the righthand side in front, and answers to the legal summons. The Queen, as defendant, enters when ealled for, aud 
takes her place on the opposite side. Here is history transferred to the boards, and blended in perfect accordance with the Shakespearean text. Even in a dramatic sense, the present arrangement is superior to the former one.

Another and more important evidence of sound judgment was manifested in the restoration of the fine scene beginning the third act, wherein the two cardinals, by command of the King, visit Queen Katharine in her sad privacy, to try and prevail on her to consent to the divorce. How or why Mrs. Siddons could have been induced to sacrifice this valuable portion of her part we never could understand. Is it possible that $\mathrm{J}_{\mathrm{ohn}}$ Kemble thought it interfered with his own Wolsey, and excised it from jealousy? If so, his discrimination was terribly at fault, and his sister's complaisance seriously marred the general interest of the play, the intention of the poet, and the rapid contrast of events his genius songht invariably to produce. At this interview, Wolsey is in the plenitude of his greatness. "Take heed," says the Queen, goaded almost to madness by his hollow importunity, "take heed, for heaven's sake, lest at once the burden of my sorrows fall upon ye." In the very next scene, the implied judgment is accomplished, and we find the king-cardinal suddenly hurled, without the slightest warning or preparation, from his high estate into misery more signal and abject than that of the helpless woman he lias assisted to destroy. It would be difficult to cite a more consummate instance of Shakespeare's deep insight into the moral of all human transactions, as well as his mastery over every possible variety of dramatic effect. If Kemble could have witnessed these two scenes at the Princess's 'Theatre, he would surely have altered his opinion, and repented of his ill-considered curtailment. 
Again, we think Mr. Kean displayed the tact of a great practical artist, in cutting down the fifth act to the last scene of the christening, and by the introduction of a moving panorama, which carried us to the church of the Grey Friars at Greenwich, where that ceremonywas performed. There had been already two processions; a third would be monotonous. What is gained in other parts of the play outvalues, by an immense calculation, the portions that have been cast aside. The acting has yet to be spoken of before we dismiss the subject.

Mrs. C. Kean's Queen Katharine gave ample evidence that during her long illness she had found intervals for study and preparation. The character could not be represented in such impressive reality without deep forethought and meditative care. It was one of the finest specimens we ever saw of what has been pronounced the perfection of acting,-art producing nature. When Mrs. Siddons in the zenith of her success called upon Dr. Johnson, he asked her "which of Shakespeare's lieroines she liked best?" She answered, without hesitation, "Queen Katharine, because it is the most natural and feminine." "You are right, madam," replied the great critic, "and when you appear in that part, old and infirm as I am, I will endeavour to hobble out and see you." Now, this is clearly Mrs. C. Kean's reading of Queen Katharine, and these attributes so congenial with her own, enabled her to achieve a signal triumph. A few sexagenarian playgoers may look back with proud reminiscences, hallowed by time, to the commanding figure of Mrs. Siddons, her sustained solemnityof manner, her thrilling, deep-toned utterance, her awful majesty of deportment. All these endowments we fully admit and remember; but in simple pathos, in natural bursts of indignation when urged beyond patience, in 
the gentle, unartificial, and purely woman-like features of the character, we venture to say, and we hope without heresy, she is exceeded by Mrs. C. Kean. Mrs. Siddons may have commanded superior admiration, but Mrs. C. Kean touches the feelings with greater intensity. She suffers the woman to predominate over the queen, and mourns the loss of the king's affections with deeper regret than the decline from her worldly state. She is wounded in her heart more incurably than in her rank. This, we apprehend to have been Shakespeare's own view; and this, in our humble judgment, was never so truthfully conveyed before, and without the restored scene, would be imperfectly attempted. We have reason to believe that this opinion in substance, and almost in the same words, has been expressed by one of Mrs. Siddons's earlier and most accomplished successors, who has long retired into the privacy of domestic life. In the dying scene, Mrs. C. Kean depicted the exhaustion of physical suffering with such artistic truthfulness, that every breath was suspended, and many were the white handkerchiefs displayed as the act-drop came slowly down. The falling back after an effort to rise, and expiring in her chair, was far more natural and impressive than if she had tottered off', as heretofore, supported by her attendants. For some seconds the audience sat rivetted in absorbed attention. and no sound escaped them; but as soon as the house could recover, one simultaneous burst of applause proclaimed the power of the enchantress who had spellbound their faculties by such potent necromancy.

It would be difficult to conceive two characters more thoroughly opposed to each other than Louis the Eleventh and Cardinal Wolsey. There is craft, and cunning, and duplicity, and conscience yielding to convenience, as far as worldly matters are concerned, (Wolsey was sincere 
in his religion) in each ; but expressed after a totally different fashion. An actor of great ability might succeed in one and fail in the other; yet Mr. C. Kean has been eminently successful in both. His versatility was never more strikingly exhibited than in these two contrasted assumptions. Wolsey is a difficult, perhaps an overrated character; identified too, by the elders, with personal associations of John Kemble. The two first acts contain little beyond unimpassioned declamation, and one or two traits of individual peculiarity. In the great scene of his disgrace and fall, in the third act, the entire pith of the part is concentrated; all that he says and does before work up to that sudden catastrophe. But this single scene contains so much in a small compass that it taxes the full powers of the actor, and none but one of first-rate pretensions can grapple with it successfully.

Mr. C. Kean does not give us the hereditary Wolsey of the stage after the mannerism of any preceding actor ; but the Cardinal of history, closely followed, as the poet has transferred him from the chroniclers, and with a minute attention to every small feature, in a portrait drawn with stereotyped distinctuess.

It is fortunate for himself, as well as wholesome for the cause of the drana, when an actor can venture to eschew established notions, and strike into an untrodden path. Modern advancement permits this, while ancient prejudice shrank from it with holy horror. Mr.C. Kean's deviations from the established rule in Wolsey, were positively alarming. It may not be generally remembered, by those who have the stately mien of Kemble ever before their eyes, that the great cardinal was short in stature, and somewhat corpulent; and although haughty and imperious with the high nobility who hated hin, no man ever exceeded him in affability and courteousress of manner, when there was no political motive for 
assuming a different deportment. Mr. C. Kean carefully noted all these points, and his performance throughout was marked by the varying shades of character which this consummate actor assumed, according to the circumstances in which he was placed, and the parties with whom he came in eontact. Wolsey could simulate humility and self-command when it suited his purpose, but his natural temper was hot and ungovernable. The poet has invested him with a dignity and resignation in his fall, which eall forth universal sympathy, until we forget his unbridled ambition and arrogance in the depth of his degradation. Mr. C. Kean gave the whole of his last seene with a most pathetic eloquence, in which nature completely triumpled over systematic habits, and truth superseded hypocrisy. His eostume appeared to be taken from undoubted authorities, and so sedulously did he preserve minor details in the manners of this great child of fortune, as well as all the more important attributes, that when he crossed the stage in the first procession, he held in his hand "the hollow orange, filled with a part of a sponge, wherein was vinegar and other confections, against the pestilent airs, which Cavendish describes as his constant eustom," when passing through streets or eorridors, where he might be pressed on by many suitors. An old gentleman, on the first night observed to a friend, seated next to him, "Mr. Kean in many respects gives me a more perfect idea of Cardinal Wolsey, as history has described him, than any actor I have ever seen, and I remember them all."

Mr. Walter Lacy deserved much eredit for his personification of Henry the Eighth, which he looked to a point. His "make up" was admirable, and his acting equal to it. The monarch of many wives was a fearful companion, although Shakespeare has done all that genius could effect to humanize and render him fit for 
society, without departing entirely from historical facts. There was no safety for any head under such a truculent ruler; his humorous intervals were almost as dangerous as his paroxysms of rage. The part easily admits of exaggeration in the hands of a coarse or careless actor. Mr. W. Lacy is entitled to full credit for not yielding to a temptation sanctioned by respectable precedent. The author has given Anne Boleyn nothing to do, and little to say. Her fair representative, Miss Heath, possesses the external requisites, and satisfied the eye, which is not the least important consideration in filling up the outline of a vapid stage beauty. Mr. Ryder's Duke of Buckingham was well conceived and embodied. The part soon fades from the scene, but is invariably assigned to an important actor. Mr. Cooper, in the restored part of Griffith, spoke some beautiful speeches with great propricty and feeling. In every respect the play presented a perfect realization of history, and was universally acknowledged as such by the public, with the exception of a few constitutional sneers from the narrow minority who are never pleased, and a faint expiring groan or two from the unhappy exceptions who envy the success they can neither arrest nor attain.

On 16th July, 1855, William Farren took his final leave of the stage at the Haymarket Theatre, appearing in the seeond act of the "Clandestine Marriage." He retired into private life with a handsome fortune and a brilliant reputation, although the former, we suspect, had suffered a little from his managerial speculations at the Strand and the Olympic. For some years, increased infirmities had rendered lim so inarticulate, that it was difficult to recognise the great actor of earlier days. The genius was still there, but the physical power was wanting to give the due effect. The Times, in a very eulogistic notice, added :- "It is just 
possible that to many young playgoers, our praise of Mr. Farren may appear overcharged; so we will at once anticipate their objections by declaring that no frequenter of theatres of less than eight years' standing is qualified to utter an opinion on the subject."

On his last night, Farren acted only a portion of what had formerly been his great part-Lord Ogleby. The house was crowded. Many leading performers from various theatres testified professional respect by contributing their services, and were grouped round him for the closing scene. Miss Helen Faucit gracefully presented the veteran with a laurel wreath, and Harley flung his arms round the neck of his old stage companion. The audience, as might be expected, cheered vociferously when the curtain fell.

Mr. C. Kean's season closed on the 14 th September, 1855-a season protracted to the unusual length of eleven months. The fact spoke success; but it was a success fairly wrung from the public by Herculean exertions, in the face of many incidental obstacles, sufficient to wear out ordinary enterprise, and to exhaust restricted resources. At the commencement of the winter, the theatrical horizon presented a dreary prospect. People's minds were depressed by the recent visitation of a deadly disease, preoccupied with the novelty of war, the unsatisfactory state of affairs in the Crimea, the exaggerated reports of loss and disaster, the burden of increased taxes, and the general uncertainty attendant on a complete revulsion in the usually placid routine of social life. Many families were in mourning for the loss of dear relatives who had fallen in battle; and many more trembled to look over the columns of each succeeding gazette. There was much to think of more absorbing than the ordinary relaxations or amusements of life. It was no easy task, under these circumstances, to direct public attention to the 
theatre, and to retain it there, as if by magnetic attraction, throughout a long and anxious period. Mr. C. Kean accomplished this by untiring energy and perseverance, marking the most difficult year of his dramatic government by an event without parallel in the history of the stage-one hundred repetitions of a single Shakespearean play. It was difficult to decide whether the public or the manager should receive the heartiest congratulations on this extraordinary success. Mr. Kean, by what he had now done, raised such expectations as to what he would yet do, that it became more than difficult for him to keep pace with his own reputation. He had revived and restored to its pristine vigour the legitimate drama, so repeatedly said to be crumbling to extinction, and had good reason to be proud of what he had effected in defiance of potent obstacles. The public felt that they owed him much; and he, in his turn, could not fail to rely with full confidence on their steady support. We had been so long acenstomed to be told that Shakespeare was buried more deeply than his own Prospero promised to drown his magic book, and to hear what were once called our great national theatres mourned over as mausoleums of the departed, that our satisfaction was doubled when we found theinimitable bard once more vindicating his claims to his title, and flourishing with renewed vitality. A ehange of local situation is of no importance. It matters little where the temple is placed, if the true divinity is worshipped within. When Eneas fled from the burning ruins of Troy, he earried his household gods with him, and found a new home for them on the hearthstone of in infant colony. Mr. Kean planted Shakespeare firmly on the boards of the Princess's 'Theatre, and there he was welcomed with as much warmth as if he had never moved from his earlier pedestals. 


\section{CHAPTER VIII.}

RENEWAL OF MR. C. KEAN'S LEASE FOR FOUR YEARS-SEASON OF 18.55-6 AT THE PRINCESS' $S$-NEW FARCE OF DON'T JUDGE BY APPEARANCES-A WONDERFUL WOMAN-THE CRITIC-THE RIVALS-THE HEIR-AT-LAW -EVERY ONE HAS HIS FAULT-MRS. C. KEAN AS LADY ELEANOR IRWIN - PaNTOMIME oN THE sUbJECT OF THE MAID AND MAgPIE-HaMlet -JEALOUS WIFE-LOUIS THE ELEVENTH - MERCHANT OF VENICEDEATH OF THE GREAT TENOR SINGER JOHN BRAHAM--THE FIRST PRINTER, A NEW PLAY BY MESSRS. C. READE AND TOM TAYLOR-ARGUMENTS ON THE TREATMENT OF THE SUBJECT AND ITS HISTORICAL ACCURACY MR. C. KEAN AS LAURENCE COSTAR-FAUST AND MARGUERITE-A PRINCE FOR AN HODR-THE VICTOR VANQUISHED-REVIVAL OF THE WINTER'S TALE - EXTRAORDINARY RUN OF ONE HUNDRED AND T'WO NIGHTS-MR. AND MRS. C. KEAN AS LEONTES AND HERMIONE-CLOSE OF THE SEASON - MR. C. KEAN'S ADDRESS - NUMBER OF SHAKESPEAREAN PERFORMANCES-DEATH OF MADAME VESTRIS.

Up to the date of which we have now arrived, Mr. C. Kean had paid considerably above 6,000l. to living authors of high repute for various dramatic novelties; but the results had not answered his expectations. Shakespeare was evidently his trusting point, and to that inexhaustible mine he determined henceforward to look, for the substantial reward of his labours, and the artistic reputation he valued even more than profit.

His lease of the Princess's Theatre terminated on the 31 st of July, 1855; but he had a stipulated condition enabling him to renew on the same terms for an additional four years, by giving six months' notice. This clause, on mature deliberation, he determined to avail himself of, and laid his plans accordingly. The ensuing engagements were all made for the full term. It was 
ever a point in Mr. Kean's system to have as few changes in his company as possible. He knew the value of forces accustomed to work together, and the advantages to be derived from constant association. The most important addition to the company consisted of Mr. Frank Matthews, who joined from the Lyceum, where he had long enlisted under the banners of Madame Vestris, and Mr. C. Mathews.

The season at the Princess's opened on the $22 \mathrm{~d}$ of October. The performances commenced with a new firce in one act, by Mr. J. M. Morton, entitled "Don't Judge by Appearances;" an agreeable trifle, well selected to usher in the stately splendour of "Henry the Eighth." After one hundred repetitions, this noble drama came again before the public as fresh and attractive as during its first run. 'The christening and diorama were now omitted.

On the 27th of October, Mr. C. Dance's clever little comedy of "A Wonderful Woman," was performed, to introduce Mr. Frank Matthews in a part originally played by him,-Crepin the cobbler. This he followed by Sir Fretful Plagiary in the "Critic." The reception of the new actor (new to the boards he was then treading) testified the warm satisfaction of the audience at seeing him enrolled in the ranks, where he has since filled a conspicuous place.

"Henry the Eighth" continued to be performed for fifty additional nights before it was finally laid aside. During the early part of the season, the old comedics of the "Rivals," the "Heir-at-Law," and "Every One has his Fault," were revived in succession, and afforded opportunities of showing the general strength of the company to much advantage. It would be diffieult to select three more opposite specimens of distinet schools. Sheridan, Colman, and Mr:. Inchbald, have little in 
common except a thorough knowledge of stage effect, and the conventional technicalities, which form, what we may call the rudiments of dramatic authorship. Mrs. Inchbald has not the sparkling wit of Sheridan, the rich liumour of Colman, or the power of grouping together incidental eccentricities, which the more desultory habits of man's life supply him with in greater abundance than a female writer can have opportunities of acquiring from personal experience.

Changes of taste, as regard dramatic composition, liave become almost as rapid as the varying fashions of our garments. What pleased our fathers, and grandfathers, finds, with few exceptions, but scanty favour with their more fastidious descendants. Whether the stage has improved or deteriorated in consequence of these multiplied and ever recurring revolutions is a question difficult to decide; and which, like many others of higher importance, may be argued to infinity, without arriving at a satisfactory conclusion; and fortunate it is that such diversity of opinion should continue to exist. Were it otherwise, we should be continually jostling each other in an uncomfortable crowd, if we all travelled together on the one narrow highway of this over-populons world. As it is, every one chooses a path for himself, in which to indnlge his own peculiar bent. By some the revival of an old comedy is considered a relief and a treat; by others it is condemned as an uncalled-for resurrection, and "a bore." We plead guilty to the cliarge of ranking ourselves with the former class, even at the risk of being pronounced old and "slow," and behind the era in which we live. Fven on the score of contrast, if for notling clse, the occasional change is welcome. "Every One lias his Fault," at the Princess's Theatre was principally remarkable for the performance of Mrs. C. Kean, as Lady Eleanor Truin. To a reader of the play, the 
character appears trivial. She seldom appears on the scene, and what she says has nothing in it beyond the simplest expression of her attachment to her husband and children, with her distress at the common misery in which they are involved. There are no stilts, no tragic inflation, and no overwhelming bursts of passion; hut there is natural feeling and pathos, in the delineation "ff which Mrs. C. Kean has never been surpassed. Mrs. Iuchbald's comedy consists of dialogue rather than action. The language is easy and pleasing, but never rises into brilliant wit. The speeches do not sparkle with epigrammatic point, neither do the characters exhibit the strong contrast of humour that tells so amazingly in the broader scenes of the "Heir-at-Law." The lady's play is one of a school, which stands midway between the sentimental and the grotesque. The serious portion is certainly overstrained, yet it embraces nothing that might not occur. Fact is often more extraordinary than the wildest romance. The ingredients of the drama will be cut down to a very circumscribed allowance if nothing is to be included but what can be reeonciled to ordinary rules. No one disputes the beautiful and natural simplicity which gives the charm to Goldsmith's "Vicar of Wakefield." Yet the incidents crowded together at the close are improbable to the last extreme. 'The novel writer and the dramatist are surely entitled to the same latitude.

The usual pantomime appeared at Christmas with the usual success. The subject this year was selected by Mr. Morton from the well-known story of the "Maid and the Magpie."

On the 17th of Febrnary, 1856, died in London, John Braham, who for more than half a century had been acknowledged as the first English tenor, without a rival. Ilis age was said to he seventy-nine. It could not 
possibly be less, and might have been more, for at the time of his death he had been sixty-six years before the public. He made his first appearance at the Royalty Theatre, through the interest of his relative and teacher, Mr. Leoni, when scarcely fifteen; and this must have been somewhere about the year 1790. In 1796, being then a full-grown man, he came out at Drury Lane, in the new opera of "Mahmoud," in which John Kemble played the hero. This was the last opera composed by Storace, and was acted fifteen times. The young singer made a most favourable impression, and never afterwards lost his ground. Braham took no formal leave of the stage, although for several years before his death he had ceased to aet. At Exeter Hall and other concerts, he continued to sing almost to the last, and though uncertain, sometimes blazed out with surprising power. $\mathrm{He}$ amassed a large fortune, and lived in splendid style, entertaining the first company in the land; but in evil hour he entered into speculative management at the St. James's and the Colosseum, in both of which he sank large sums of money. When examined before the committee of the House of Commons, on the Dramatic Question, in 1832, he was asked amongst other interrogatories, whether he had ever been a manager, to which he answered emphatically, "No, thank heaven!" If he had never been tempted from this resolve, he woul have lived and died a richer man. But greater names than his have been coupled with more flagrant inconsistency. The Duke of Wellington said in the House of Lords that he must be mad before he would undertake the duties of prime minister. Yet he was installed in the office not long after he volunteered this declaration.

On Monday, the 3d of March, 1856, a new play in three acts was produced, entitled the "First Printer," the subject of which is cmbodied in the title. An 
original composition; with no French leaven, but all genuine English. The authors, Messrs. Charles Reade, and Tom Taylor (dramatists of established repute), adopt the Dutch version of the origin of typography, and ascribe the exclusive invention to Laurence Costar, sacristan of the Cathedral at Haarlem. While setting aside the more recognised claim of John Gutenberg of Mentz, they have even drawn the latter as a common pilferer, and trader in goods dishonestly obtained. In a preliminary notice affixed to the bill, it was stated that they founded their opinion on the faith of a tale handed down by Adrian Junius, the celebrated antiquary, and principal of Haarlem College. According to this gossip, one Master Cornelius, a bookbinder, who died in 1516, recollected and told how a certain John, who worked with him in the employment of Costar, when they were both lads, broke into the shop and abstracted the printing apparatus, flying to Mentz, where he set up on his own account. "If this story be true," say Messrs. Reade and Taylor, "it follows from the uncontested facts of the history of printing in Mentz, that this John could have been no other than one of the Gutenbergs." We confess that we cannot see the logic of this assumed conclusion, but look upon it as resting on a shadowy basis. That the Dutch legend presents preferable points of dramatic effect, would seem more like an argument, however the alleged facts may deviate from historical truth. The question has given rise to much controversy, and is likely to remain unsettled.

If we are to judge by such evidence as has reached us, it appears most likely that the first conception of printing emanated from Costar, who invented wooden blocks. With these, he printed, about the year 1438 , and a very short time before his death (which took place in 1439, at the age of sixty-nine), a book of images and letters,

VOL. II. 
entitled "Speculum Humanæ Salvationis ;" and compounded a species of ink, more glutinous and less likely to blot than that in common use. The leaves of this book were printed on one side only, and afterwards pasted together. Gutenberg improved most materially on the idea of Costar, by the invention of moveable wooden types, which Peter Schæffer carried to the perfection of the cast metal types in matrices now in use. The German writers reject the Haarlem tale, and insist on the superior pretensions of Gutenberg. Lamartine, in his recent memoir of the latter, supports the integrity of his character and the extent of his genius, while admitting that Laurence Costar was the father of the thought. He says, "the discovery of the poor sacristan would have covered the surface of the earth with plates engraved or sculptured in relief, but would not have been a substitute for a single case of moveable type. Nevertheless the principle of the art was developed in the sacristy of Haarlem, and we might hesitate whether to attribute the honour of it to Costar or Gutenburg, if its invention had not been with one the mere accidental discovery of love and chance, and with the other, the well-earned victory of patience and genius."

There have not been wanting desperate antiquaries who carry back this wonderful discovery to an infinitely more remote period. Some maintain that printing was in use during the building of Babylon, and others that the knowledge of the art came even earlier than that epoch from the Chinese. Abdalla's "Chinese History" notices wooden tablets engraved to print entire pages on one side of the leaf, and ages afterwards practised by Costar and other block-printers, in the Low Countries.

Where historical characters are introduced into a poem, a novel, or a play, poctical licence usually claims 
the privilege of exalting or depreciating them according to the immediate object of the writer. Is this practice justifiable? It has multiplied precedent, if not law and reason, on its side. In the case now under discussion, Gutenberg's children died before him, and he has left no heir or representative to feel hurt at an imputation on his memory, or to prosecute for libel if he has been unjustly dealt with.

The play is well written, and the interest powerfully sustained; but there is something unsatisfactory in the conclusion. The same principle of dramatic licence, in the exercise of which the autlors have blackened the character of Gutenberg, called upon them to punish him in proportion to the enormity of his guilt. He loses, it is true, the wife he sought to filch from his rival, but he retains the credit of his stolen invention, his consequent riches, his reputation, and his rank as master of the guild. To a worldly-minded man he has more than an equivalent for the loss of domestic happiness. As the authors have strained history in the first point, they were the more bound to do so in the second. When Euripides was blamed for bringing such a flagitious villain as Ixion on the stage, and visiting him with temporary prosperity, he replied, "but yet I brought him not off till I had fastened him to a burning: wheel."

There are, moreover, some anachronisms in the "First Printer" which could not fail to be generally recognised. The biographical dictionaries tell us that Laurence Costar was born in 1370, and died in 1439 . Assuming these dates to be correct, it is impossible that he could have met Gutenberg at Mentz in 1440, he himself being still young in years. Again, the famous Mentz Bible, spoken of in this play as already printed, was only commenced in 1440, and finished in 1460; 
and the honours conferred on the society of printers by the Emperor Maximilian, together with their erection into a guild, did not take place until long after the death of Gutenberg, in 1468.

The part of Laurence Costar, maintained by Mr. C. Kean, fell quite below the mark of the leading actor of the day. But he threw his whole energies into it, and made it stand much more forward than the authors could have anticipated from the materials with which they supplied him. In the scene of the third act, with Gutenberg, he exhibited surprising power. The struggle between physical exhaustion and intense passion was given with startling reality. Such efforts of the actor's art furnish examples of what genius can embody from a faint outline, and profitable lessons to young performers how the experience of a great master discovers efforts which the scholar in his apprenticeship often passes over, or is incapable of distinguishing. A strong part may be made to tell in comparatively weak hands, but a weak one requires the strength of a giant to sustain its importance.

A play of so much merit, well acted and carefully got up, eulogised by the press and warmly applauded by the audience, might have been expected to enrich the treasury and remain long on the acting list. On the contrary, it added one more to the insolvable problems of public caprice. After nine representations it was withdrawn, simply because the receipts fell regularly below the nightly expenditure, without any prospect of reaction.

On the morning of the 6th of March, 18.56, while darkness yet prevailed, the inhabitants in the neighbourhood of Covent Garden Theatre were startled from their slumbers by the announcement of that splendid edifice being on fire. In a few hours it was entirely consumed. 
The discovery was made before an assembly of many thousands, who had been revelling in the saturnalia of a bal masqué, given by Professor Anderson, the Wizard of the North, had entirely dispersed. Fortunately, the lingering revellers were few in number, or the alarm might have occasioned a fatal rush, in which many lives would in all probability have been lost. Not long sinee (in February, 1859) the great Théatre du Cirque, at St. Petersburg (devoted to Russian operas and German comedies), met destruction from fire, and also during or immediately after it had been prostituted to a similar desecration. These masquerade balls are as dangerous. as they are undramatic and demoralizing. It is marvellous that the authorities do not prohibit them in public places, or that the proprietors of theatres expose their buildings to unnecessary risk by letting them for such unhallowed purposes. Covent Garden rose phœenixlike from its ashes with increased splendour, and in less than six months from the laying of the first stone the new theatre opened, on the 15th of May, 1858, with the opera of the "Huguenots." There were many speculations as to what would be built on the ground, and whether or not it would ever again be occupied by a dramatic edifice, after two conflagrations, occurring within fifty years. Superstitious observers, as they passed by, might have said or thought, as they gazed on the ruins, and the lumbered site,--

"A merry place it was in days of yore,

But something ails it now ; the place is curs'd."

But the roid is filled up by Mr. Gye's magnificent building, one of the most commodious and perfect theatres in Europe, specifically ereeted as an Italian Opera House, and so constructed as to be equally available for any variety of dramatic entertainment. There 
Miss Pyne and Mr. Harrison have, with their wellselected company, recently elevated the standard of national music for the encouragement of English art and artists, with the success which their energy and ability so amply deserve.

During the Easter week, "Faust and Marguerite" was again brought forward, supported by two light pieces, entitled respectively, "A Prince for an Hour," and the "Victor Vanquished;" the first by Mr. J. M. Morton, the last by Mr. Charles Dance. One introduced, the other concluded, the performances. Both were favourably received, and acted for more than fifty nights. The "Victor Vanquished," a comedietta in one act rather than a farce, is an ingeniously contrived and elegant little drama, abounding in pointed and sparkling dialogue. The characters are confined to three,Charles the Twelfth of Sweden, the Baron de Gortz, his private secretary and minister, and Ikla, a Tartar princess, the Baron's niece. It can scarcely be called historical, for the leading incident implies that the renowned Alexander of the North once bowed to the influence of Cupid,-an assumed fact of which we have no evidence, but still permissible as a dramatic liberty, even where such an acknowledged misogynist is concerned. The traditional attributes of Charles the Twelfth, with his strong personal peculiarities of manner and dress, are so familiarly recognized, that when he appears on the stage, we are prepared to look on a well-known animated portrait stepping from the frame. Mr. F. Matthews, his impersonator on this occasion, had evidently studied the Royal Swede with the care of a discriminating artist, and presented him in living identity. Nothing was overdone; while the clear, succinct phraseology, and unique military bearing, were faithfully preserved. 
On the 28th of April, Shakespeare's "Winter's Tale" added another to the series of great classical illustrations by which Mr. C. Kean continued with unremitting perseverance to mark the distinctive feature of his management.

When it began to be rumoured that a Greek play was in rehearsal at the Princess's, with all the usual preparation and research, many thought that Mr. Kean was about to venture on the bold experiment of going back to first principles, and intended to draw from the stores of the early fathers of the drama, Sophocles or Euripides. When it became known that the projected revival was to be Shakespearean, the "Comedy of Errors," "Troilus and Cressida," "Pericles," or "Timon of Athens," presented themselves as the probable subject of selection ; but no one thought of the "Winter's Tale." No sooner was the fact announced in the bills, than there arose much difference of opinion as to the judiciousness of the choice, and the means it supplied. What can be done with the "Winter's Tale"? was asked by experienced play-goers. The plot was known to be incongruous, the play full of anachronisms, uncertain in epoch, confused in locality, irregular beyond all precedent or comparison in construction, and hitherto unattractive. These objections were pronounced insurmountable. Mr. Kean grappled them with a compelling hand, and triumphed over all. Without altering the original text, but merely by pruning and excision, he triumphed over conflicting difficulties which had baffled the ingenuity, and developed innumerable beauties which had escaped the notice, of his most eminent predecessors.

After the re-opening of the theatres on the extinction of the Commonwealth, and the return of Charles II., the genius of Shakespeare suffered a long eclipse, or only 
glimmered faintly through the vile imitations and alterations which the corrupt taste of the day permitted to supersede the majestic originals. Downes, in his Roscius Anglicanus (1708), mentions that during a long series of years, and in a list of fifty-one plays, frequently represented, only three of Shakespeare's are to be found ; so little was the great dramatist known and followed at that time. Garrick swept away many of these worthless substitutes, but he still retained some, and added a few of his own when it suited his purpose.

Shakespeare has been condemned by worshippers of the unities for making Perdita an infant in the third act, and a woman in the fourth, passing over sixteen years with a short address from Time as Chorus, to explain the intermediate lapse. The censure is more hasty than sound. His play, thus divided, is, in fact, a bilogy, a story related in two distinct sections-a preliminary and a sequel, strictly in accordance with classical rule and precedent. Garrick destroyed the connexion by omitting the first part of the action, and opening the second with a short narrative only of the events that had oceurred; namely, the jealousy of Leontes, the assumed death of Hermione, and the exposi::e of her infant. To feel and understand Shakespeare, we must take him as he is, "with all his imperfections on his head," or reject him altogether. Egrescitque medendo-by being cured he grows sick. Scenes may be cut out or curtailed, and objectionable superfluities may be expunged; but there is something so clear, comprehensive, and identical in all Shakespeare's designs, that any material alteration mars them entirely. John Kemble cast aside Garrick's condensation of the "Winter's Tale," but retained his added dialogue in the last scene. Macready did the same. As actors, they thought the parts of Hermione and Leontes heightened by having more to say at the 
close. Shakespeare, guided by nature, knew that, under the circumstances of their unlooked-for re-union, they would feel more than they could utter, and has given them very few words. Mr. C. Kean, by adhering to the original text, has proved himself the ablest commentator and most faithful restorer of the poet's meaning. His object is well conveyed in the passage with which he concludes the prefatory notice attached to the playbills:- "I have endeavoured," he there says, "and I hope not altogether in vain, by the united accessories of painting, music, and architecture, in conjunction with the rapid movements and multiplied life which belong to the stage alone, to re-embody the past; trusting that the combination may be considered less an exhibition of pageantry appealing to the eye, than an illustration of history addressed to the understanding."

Our readers are as well acquainted as we are with the sources from whence Shakespeare has drawn his plot, the new characters he has created, * the exquisite poetry he has scattered through the play, and the graceful surprise with which he winds up the catastrophe. We pass from any trite dissertation on these points, which have been so often discussed, to a review of the play as produced at the Princess's Theatre. It now belongs to the past, and is not likely to be witnessed again ; although Messrs. Bradbury and Evans's printed edition supplies all that reading can substitute for the animated reality.

As the curtain rose, we saw before us Syracuse at the epoch of her highest prosperity, about 330 B.c., and gazed on the fountains of Arethusa and the temple of Minerva. After the short introductory scene between Camillo and Archidamus, we passed to the banquetinghall in the Royal palace, where Leontes, Polixenes, Hermione, and guests were discovered reclining on couches,

*Antigonus, Paulina. Autolyrus, and Clovn. 
after the manner of the ancient Greeks. Musicians were playing the hymn to Apollo, and slaves supplied wine and garlands. Thirty-six resplendently handsome young girls, representing youths in complete warlike panoply, entered, and performed the evolutions of the far-famed Pyrrhic dance. The effect was electrical, and established at the commencement an impression of what might be expected as the play advanced. The action then proceeded, with the frenzied jealousy of Leontes, his commission to Camillo to murder Polixenes, and the escape of the two latter by flight.

At the commencement of the second act we were presented with a beautiful interior, representing Hermione in her domestic privacy, surrounded by the young Prince Mamillius, and her attendant ladies. They are interrupted by the violent entrance of the King, whose insane delusion has increased with the departure of Polixenes, and the innocent Queen is borne away to prison. In the next scene, a representation of one of the dreary "Latomiæ," or excavated dungeons, known as the "Ear of Dionysius," conveyed a corresponding idea of the severity with which the guiltless Hermione is treated. We then return to the palace, and find Leontes still torn by groundless passion, and meditating. extreme vengeance. Paulina enters with the new-born infant, lays it at his feet, upbraids him with his tyranny, and defends her absent mistress in a torrent of indigniant eloquence, until she is driven from the apartment. Antigonus, her husband, is sworn by the King, on a most solemn oath, involving his own life in pledge of obedience, to convey the babe to a remote, desert land, and leave it there exposed to the chances of fortune.

The third act comprised the trial of Queen Hermione in the public theatre at Syracuse, the usual hall of judgment on great public occasions. The arrangement of 
the stage here presented an astonishing instance of scenic illusion. The area is extremely limited; yet, by pictorial and mechanical combination, it appeared to expand to the colossal proportions which we read of as belonging to the most celebrated of those ancient buildings in which thirty thousand persons might be seated on the benches.* A wonderful realization was presented by the dense-assembly of auditory and officials; by the imposing appearance of the King on his throne, with sages and councillors ranged behind and on each side of him; by the arraigned Queen, borne in on her litter, with attendant females; and by the solemn procession of the Oracle. When these were grouped together, and the varying emotions of the whole assembly reflected in animated gesticulation and expression, as the incidents of the scene proceeded,-the rapt, intense attention of the entire house suspended applause for the moment; but at the close they relieved themselves by reiterated bursts of acclamation. The excitement had scarcely subsided, when, after a considerable interval, the curtain rose again for the fourth act.

In this portion of the play Mr. C. Kean substituted Bithynia for Bohemia. The idea originated with Sir Thomas Hanmer, in his annotations to his own edition of Shakespeare (1744). The change of locality obviates the cavil that has often been raised against the incongruity of making Bohemia a country bordering on the sea. The difference of name, as Mr. Kean observes in his preface, " in no way affects the incidents or metre of the play, while it affords an opportunity of representing the costume of the inhabitants of Asia Ninor at a corresponding period, associated so intimately with

* The Theatre of Bacchus at Athens could accommorlate this number. Syracuse at one time exceeded even Athens in extent and external magnificence. 
Greece, professing the same form of paganism, and acquiring additional interest from close proximity to the Homeric kingdom of "Troy."

Antigonus lands on a desert spot on the coast, and leaves the infant Perdita to her fate. His vessel, with all on board, is wrecked, and he himself torn to pieces by a bear. An old shepherd and his son find the child, with the accompanying gold and jewels, and bear it off to be reared in humble obscurity. Clouds now descended and filled the stage, leading to a classical allegory, representing the course of Time. As these clouds dispersed, Selene, or Luna, was discovered in her car, accompanied by the Stars (personified by living figures), and gradually sunk into the ocean. Time then appeared, surmounting the globe, no longer represented by the raditionary bald-headed elder, with his scythe and hourglass, but as a classical figure, more in accordance with the character of the play as now represented. He spoke the lines with which Shakespeare has connected the two separate epochs of his play. As Time descended, Phoebus rose with surpassing brilliancy in the chariot of the Sun, encircled by a blaze of light which filled every portion of the theatre. The group appeared to be derived from that in the centre of Flaxman's Shield of Achilles. The horses were modelled with a life and fire that would have done honour to Baron Marochetti himself. The statue-like grace and immobility of Apollo, as he stood in the car, reining in his impetuous steeds, impressed a universal conviction that this figure also was artificial; but the living reality was conveyed in the most startling manner, when, at the full height of his ascent, he suddenly raised his right arm to lash a restive courser. The effect baffles description. The entire allegory may be pronounced the greatest triumph of art crer exhibited on the stage. 
As the allegorical pictures dissolved, we found ourselves transported to the palace of Polixenes, in Bithynia, and thence to a road-side landscape, where we were introduced to the merry knave Autolycus, in the practice of his thieving vocation, derived from his father Mercury; his selected victim being the unsuspecting Clown. An extensive pastoral scene succeeded, rich in the luxuriance of Eastern foliage, with a distant view of Nicæa, the capital of Bithynia, on the lake Ascania. Nothing could be more delightful than this complete change from the gorgeous palatial magnificence of the earlier portion of the play; and in this contrast of sylvan, as opposed to city life, with the appropriate dialogue and imagery he has placed in the mouths of his new actors, the endless variety of Shakespeare's genius is most beantifully depicted. A dance of shepherds and shepherdesses comes in so naturally, and was performed with such exquisite grace, and a musical accompaniment so completely in harmony with the scene, that we almost fancied ourselves in Arcadia during the golden age. The feeling thus produced on the mind of the spectator, is imbued with the refined sentiment gathered from the contemplation of a landscape by Gainsborough, or the Infant Joln of Murillo. From this delicious dream we were roused by the boisterous merriment of the Dionysia, or grand festival of the vintage, in honour of Bacchus, executed by an overpowering mass of satyrs, men, women, and children, in wild disguises, and with frantic energy. There must have been at least three hundred persons engaged in this revel of organized confusion, which worked up to a maddening burst at the end, when they all rushed out, presenting a perfect revivification of Comus and his Bacchanalian crew. The act terminated with the discovery of Polixenes, who had attended the rustic festival in disguise; his bitter denun- 
ciation of the attachment of his son and heir, Florizel, for the supposed shepherdess Perdita; and the consequent flight of the young lovers to Sicily, through the agency of Camillo.

The fifth act is curtailed with infinite advantage, and hastens rapidly to the conclusion. The garden of Leontes, adapted from a drawing found at Herculaneum, exhibited the bereaved monarch, bowed down more by remorse than time, mourning the result of his madness, which has left him alone in his guilt and fruitless penitence. Florizel, Perdita, Camillo, and Polixenes arrive in succession. The King discovers his lost daughter, and the long-severed friends are reconciled. But a crowning happiness is still in store for Leontes, which he little deserves. Paulina invites him to her mansion to look on a marvellous statue of his deceased Queen. It is herself; and instead of inanimate marble, he embraces living forgiveness. This closing scene has ever formed the great charm of the play. Mr. C. Kean contrived to invest it with such imposing novelty, that although it, wound up a long series of extraordinary effects, each rising above the other, it surpassed them all. The procession by torchlight, the passing round the peristyle within which the statue is placed, the grouping when Hermione was discovered, the expression of wonder at the first stir of her head, and the general movement as the curtain falls, are all within the ample list of his own stage improvements, and the result of the unwearied study and research he brought to bear on this captivating drama, from the beginning to the end.

The action of the "Winter's Tale" turns entirely on the sudden jealousy of Leontes. Shakespeare has exhibited this overwhelming passion in three opposite characters, and under very distinct aspects. With 
comic extravagance in Ford, with progressing passion in Othello, and with frenzied suddenness in Leontes. In the latter instance he has been censured by methodical critics, who accuse him of abruptly departing from nature. The jealousy of Leontes, according to them, is unskilfully imagined, in being so utterly baseless, and in the little preparation with which the coming torrent is presented in such overbearing rapidity to the audience. He has no subtle poisoner, no Iago to pervert a mind easily excited. But before we question the workings of jealousy, let us remember what the great master says in another place of the nature of this impulse, which he has depicted with such terrible energy :-

"Jealous souls-are not ever jealous for the cause, But jealous for they are jealous ; 'tis a monster, Begot upon itself, born on itself."

Othello is gradually wrought upon by treachery; Leontes creates and feeds his own disease. When he utters to himself the first words indicating that the fever is on him - "At $m y$ request he would not," with reference to the yielding of Polixenes to prolong his stay at the entreaty of Hermione, and again when he says soon after,-

\section{"Too hot, too hot!}

To mingle friendship far, is mingling bloods ;"

the audience wonder, and are unable to comprehend his meaning unless prepared for it by something in his previous deportment. Mr. C. Kcan, with the comprehensive genius of a great actor, leads up to this from the opening of the scene. The idea, which we never observed to have been conveyed by any preceding representative, appeared to the audience as original as it was artistically executed. By Mr. Kean's arrange- 
ment of the stage, Hermione is seated at the foot of the couch of Leontes, in earnest conversation with Polixenes, their guest, who bends forward to address her. Leontes anxiously watches them, as if his mind were already disturbed by the suspicion of undue intimacy; and when they descended to the front, after the conclusion of the banquet, his manner of soliciting his friend to remain, and his demeanour in their subsequent dialogue, was at intervals cold though courteous, studied but not warm, diplomatic more than affectionate, an effort of the tongue rather than a desire of the heart. It told the story of what was to come, and the profound study with which the actor had mastered the subtle conception of his author. In the following interview with Camillo, when Leontes gives way entirely to the demon that possesses him, the expression of Mr. Kean's eye, and the rapid variation of his features, resembled the flash which precedes the thunderbolt and heralds in the approaching storm.

Throughout the second act, he sustained the torrent of passion with unabated fervour; and in the third, at the trial, calmed down to a collected sternness of manner, in tone with the solemnity of the proceedings. His agony of remorse at the end, when the sudden deaths of his wife and son are announced in quick succession, and the total change in his deportment from the stern despot to the stricken man, marked the care and intelligence with which he felt and threw out in strong variety, the multiplied shades of the character.

Shakespeare has beautifully relieved this play, by the pastoral episode which occupies the fourth act. In the fifth, we return to the court of the bereaved monarch, bereaved through his own mad intemperance. When Mr. Kean came into his garden, broken in spirit, faded 
in form, and prematurely old, the contrast he presented to the manly vigour we had belicld in the earlier scenes, again demonstrated the perfect mastery of the actor over his art. His reception of Florizel and Perdita was touchingly subdued, and the instinctive affection with which he gazed on the lovely shepherdess prepared the audience for the recognition. But Leontes has yet another revulsion of feeling to undergo before his part is over. From hopeless sorrow and unavailing repentance he is raiscd to inexpressible happiness, by finding that the supposed statue of his long-mourned Queen is her animated reality. Here the poet has given Leontes little to say; but he has left him a world of meaning to convey by look and expressive gesture, more eloquent than words.

What shall we say of Mrs. C. Kean's Hermionewhether in appearance, costume, manner, elocution, or conception? It was exquisite throughout. The character is thoroughly feminine, and divested of resentful feelings. Even when her life is in imminent danger, she grieves more for the "crown and comfort" of that life, her lord's favour, and for the apprehension of a taint on lier fair fame, than for any dread of extreme punishment. She has no angry feelings against Leontes, even while he is destroying her. When Shakespeare drew this and other enchanting ideals of physical and moral perfection, he must have foreseen in poetical perspective that a time would come when, instead of being impersonated by youths, as in his ruder age, they would find more congenial representatives in lovely and accomplished women.

There is not the intense passion developed in Hermione that characterises her more fiery husband; but there is equal variety of feeling, with superior grace, and the added charm of innocence wrongfully accused. We

VOL. II. 
cannot understand the criticism of Horace Walpole, who considers that Shakespeare intended the "Winter's Tale" as a sequel to "Henry the Eighth;" and we are still more confounded when we are told of the strong similarity between Hermione and Katharine of Arragon. Both are exposed to a trial, it is true, but under circumstances as distinct as their respective demeanour. In the case of Katharine, the trial is a mere judicial proceeding for a divorce; in that of Hermione, it is a solemn indictment for life or death. These trials establish no more relationship or comparison between the two heroines than honest Fluellen is able to make out between Alexander the Great and Harry of Monmouth, on much the same line of argument; namely, that there is a river in Macedon and another in Wales.

In the celebrated statue scene, which concludes the play, Mrs. C. Kean's interpretation of the poet's meaning differs entirely from that of her most eminent predecessors. A graceful or imposing attitude has been often assumed; but she adopts that which accords exactly with the language of the text. Leontes says:-

$$
\text { "Oh, thus she stood, }
$$

Even with such life of majesty,When first I woo'd her !"

The position directly implied maiden bashfulness, listening to a favoured suitor; and when, at the proper time, she gently raised her head, and extended her right arm, the action spoke, "Take me, I am yours," more emphatically than words could have conveyed the sentiment. The chisel of Phidias or Praxiteles never wrought an effigy in marble to surpass the motionless beanty and grace of this noble figure,-motionless and still as air, until summoned into life. Her manner of descending from the pedestal, and her silent embrace of Leontes, 
spoke returning affection more powerfully than could have done a volume of words.

The youthful lovers, Florizel and Perdita, found charming impersonators in Miss Heath and Miss C. Leclercq, who looked, moved, and spoke as if they had been born and bred in a sylvan paradise. When Garrick revived the "Winter's Tale," he wrote and introduced a song for Perdita, which was afterwards displaced for another by Sheridan, not more suited to the character and the play than the first. Taste in Shakespeare has happily advanced far beyond the point when the conceits and prettinesses of the Della Cruscan school of verse were considered as amongst the leading attractions, in one of his most poetical and imaginative plays.

The "Winters Tale" continued to run without interruption for one hundred and two nights, to the close of the season, which took place on the $22 \mathrm{~d}$ of August. Early in July a light prelude, under the title of "Music hath Charms," adapted from the French by Mr. D. Fisher, of the Princess's company, varied the introductory performances. On the last night, Mr. and Mrs. Kean were loudly called for, and received with reiterated acclamations. Mr. Kean then came forward alone, and spoke to the following effect :-

"Ladies and Gentlemen,-In obeying your kind summons, I take the opportunity of expressing my deep sense of gratitude for the constant favour with which you have received my efforts since I first entered upon management-a favour which has enabled me to present to you some of the most beautiful creations of the greatest of all poets, with a success and attraction unprecedented in the annals of the stage. Such results convert the most hazardous risk into triumphant 
certainty, and convince me that I have struck the right chord in endeavouring to make the stage a correct embodiment of what is true, real, and picturesque. We have now reached the last night of our season, and the one hundred and second representation of the 'Winter's Tale;' but I can scarcely say 'farewell,' as in a few days I hope once more to bid you 'welcome.' On Monday, the 1st of September, this theatre will reopen, with a revival of Sheridan's play of 'Pizarro,' with the same attention to details which have accompanied our previous series of historical illustrations. In the meantime, Ladies and Gentlemen, on the part of Mrs. Kean and myself, I beg to tender you our respectful thanks and assurances of continued zeal in your service."

It has seldom happened that an actor of Mr. C. Kean's celebrity has been supported by a partner equal in ability to himself. This rare union gives them an exclusive advantage. The cry of Mr. Kean's detractors became fainter and fainter, as every succeeding season more firmly established his reputation. Still there were a few who continued pertinaciously to bark, though no longer able to bite, and whose malignity was at least equal to their impotence. A little before the season closed, one of these impartial critics was indulging, in a mixed company, in loud and general condemnation of the "Winter's Tale," as produced and acted at the Princess's Theatre. On being asked if he had seen it, and closely pressed for an answer, after fencing as long as he could, he muttered a hesitating "No." This short monosyllable comprises a folio of commentary on the value of opinions which are not unfrequently delivered on equally sound foundations.

During the season which now terminated, twenty 
different pieces were acted, of which four only were new. Out of two hundred and forty-nine acting nights, one hundred and sixty-seven were devoted to Shakespeare.

Before we close this chapter, the death of Madame Vestris must be noticed, which took place on the night of Friday, the 8th of August, 1856, at her residence, Grove Lodge, Fulham, after a long and painful illness, which had prevented her from appearing before the public for more than two years. Her last appearance was on the occasion of her husband's (Mr. C. Mathews) benefit, at the Lyceum, on Wednesday, July 26th, 1854, in "Sunshine through Clouds," a translation of Madame de Girardin's play, "La Joie fait Peur." She was the daughter of the well-knowl engraver, Bartolozzi, and at the age of sixteen married II. Armand Vestris, at that time principal dancer and ballet-master at the King's Theatre in the Haymarket. Very soon after her marriage, in the year 1816, being an accomplished musician and linguist, she came out as Proserpina, in the Italian opera of "Il Ratto di Proserpina." The age of professional persons who have been long before the public is invariably exaggerated. This was particularly the case with IIadame Vestris; a strange propensity in human nature, which delights in making our friends and contemporaries older than they really are, forgetting that if time gallops with them, it is not likcly to amble gently with ourselves. But the weakness originates in the vanity which many give way to, of deducting a goodly decade or so from the sum total of their own register.

Not producing the effeet that was expected, Madame Vestris accompanied her husband to Paris, and played for some time in tragedy and comedy in the French language, of which she was a perfect mistress.. Sepa- 
rating from M. Vestris, she returned to England in 1819. She engaged with Elliston, at that time manager of Drury Lane, and shortly after established her fame in a burlesque of Mozart's grand opera, called "Giovanni in London," in which she, as the hero, and Harley as Leporello, created an extraordinary sensation. From that time she continued a leading favourite in the light range of the drama, both at Covent Garden and Drury Lane, until in 1829 she became lessee of the Olympic Theatre, which she speedily transformed into one of the most fashionable temples of the dramatic art in London -a perfect theatrical boudoir.

In the year 1838, Madame Vestris, whose first husband had died in 1825, married Mr. Charles Mathews, and, leaving the Olympic under the management of Mr. Planché, they started immediately for America. The stars of the Olympic made but a slight impression on Cousin Jonathan, and returned to England in 1839, in the September of which year they entered on the lesseeship of Covent Garden. Here Madame Vestris introduced the system of furnishing the drawing-rooms of modern comedy with the sumptuous elegance of the saloons of the nobility. But the plan was too expensive for the receipts, although the company comprised a host of talent, and the best writers were retained to supply a constant succession of novelty. The lessees retired with a heavy loss at the end of their third season, in April, 1842. In 1847 they opened the Lyceum, where the old Olympic revels were revived, and many of the former actors and authors once more rallied under their former standard. Madame Vestris played several new parts of importance; but latterly, as her strength began to fail, she principally confined herself to the direction of the stage, and the charge of the wardrobe, in both of which departments she evinced extraordinary taste and talent. 
Her name will long be remembered as one of the most attractive actresses and agreeable singers of her day. Her peculiar excellences lay in a natural ease, gracefulness, and vivacity, without apparent effort; in the elegance of her costumes; and in her scrupulous adherence to the text of the author, even in the lightest of farces or interludes. 


\section{CHAPTER IX.}

SEVENTH SEASON UNDER MR. C. KEAN'S MANAGEMENT, AT THE PRLNCESS'S THEATRE-REVIVAL OF SHERIDAN'S PIZARRO, WITH ALTERATIONS AND ADDITIONS - PREFATORY NOTICE - DIFFERENT OPINIONS AS TO THE LITERARY MERIT OF THE PLAY-MR. AND MRS. C. KEAN AS ROLLA AND ELVIRA-HISTORICAL MISTAKE OF KILLING PIZARRO IN THE ORIGINAL PLAY - GREAT SUCCESS OF THE PRESENT REVIVAL, SIXTY-EIGHT REPETITIONS-NEXT SHAKESPEAREAN PERFORMANCE-A MIDSUMMER NIGHT'S DREAM-EARLY ALTERATIONS OF THIS PLAY-GARRICK'S OPERA IN 1763-THE FAIRIES REPRESENTED BY CHILDREN-COLMAN'S ADAPTATION IN 1777-REYNOLDS'S MUSICAL VERSION AT COVENT GARDEN IN 1816-MADAM VESTRIS's REVIVAL AT COVENT GARDEN, AND MR. PHELPS'S AT SADLER'S WELLS-BOTH EXCELLENT-MR. C. KEAN'S RESTORATION OF THE ORIGINAL PLAY RUNS FOR ONE HUNDRED AND FIFTY NIGHTS DURING THE FIRST TWO SEASONS-THF ROSE OF AMIENS, A COMEDY IN TWO ACTS, AND THE PANTOMIME OF ALADDIN, BOTH BY MR. J. M. MORTON.

Mr. C. KEגN's seventh season commenced on Monday, September 1st, 1856, after a short recess of one week only. On this occasion, he revived Sheridan's adaptation of Kotzcbue's "Pizarro," a play that enjoyed great reputation in its day, but had not been acted in London for many years. The subject was entirely new to the present gencration. The reasons for this selection were set forth by Mr. Kean in the following preface, appended to the play-bills, and newly printed edition :-

"The success which has attended a series of historical illustrations at the Princess's Theatre, can leave no rcasouable doubt that public taste approves this description of entertainment. In compliance, therefore, with an opinion so unequivocally conveyed, I have sought for a fresh chapter in the pages of the past, which may combine 
with the revival of a popular play, appertaining to a deeply interesting period, much that is novel in the accompanying arrangements.

"Herctofore, with the exception of 'Sardanapalus,' the subjects have been chosen from the creations of Shakespeare. In the present instance, I have selected the well-known drama of 'Pizarro,' for the purpose of exemplifying the customs, ceremonies, and religion of Peru at the time of the Spanish invasion.

"The discovery of the Western hemisphere, by Christopher Columbus (the most astounding achievement in the annals of human enterprise), opened a way to the numerous successors of that illustrious pioneer, who penetrated region after region of the vast continent, eager for conquest and for gain.

"Europe received the startling intelligence, that instead of being occupied by tribes of rude and ignorant savages, Mexico and Peru teemed with millions of humanized beings, far advanced in civilization, power, and refinement.

"In fact, 'Pizarro' and his followers had found the Kingdon of the Incas inhabited by an industrious, disciplined population, united under the sway of a paternal government, possessing numerous works of art, and many national memorials. While nature appeared to revel in her grandest and most picturesque aspect, the land abounded with precions gems and metals to such an cxtent, that amidst the gardens of temples and palaces, trees and plants of gold and silver, most exquisitely manufactured, stood intermingled with natural productions. Birds of the same costly materials were scen upon the artificial branches, and the interior of the great Temple of the Sun, the most magnificent structure in the new world, was probably unsurpassed in the richness of its decoratious by any building in the old. 
"In the production of 'Sardanapalus,' in 1853, I availed myself of the discoveries of Layard and Botta, to place before the public a restoration of one of the earliest cities enrolled in the world's record. On the present occasion, I venture to hope that a corresponding interest may be excited by the revival of an epoch equally wonderful, although dating little more than three hundred years antecedent to the present time.

" By the recent excavations in Assyria, entombed races were raised before the eyes of the living; while through the adventurous and unscrupulous spirit of the Spanish conquerors of America, in the sixteenth century, vast nations, buried in obscurity, unknowing and unknown, were revealed in active existence, occupied with the pursuits of cultivated life. We read, with surprise mingled with awe, of an extensive empire, whose mysterious origin is lost in the labyrinth of ages, confined within its own limits, seeking no external intercourse; - of a people dwelling in towns and hamlets, clustered amidst orchards and gardens, constructing canals and subterraneous aqueducts, carrying roads over plains and across mountains, forming beautiful terraces on the sides of the Cordilleras, which bloomed with every variety of vegetation; rich in flocks, that supplied garments of the finest wool, victims for the altar, and viands for the banquet; crecting palaces for their Incas, and temples for their God, with a profusion of wealth within the walls that almost rival the marvels of Arabian fable; and what is most remarkable, enjoying the intellectual and refined amusement of a poetical drama!

"In adapting the selected play to the purposes of historical illustration, passages have been abbreviated which appeared unimportant, and several additions made to carry out the object chiefly in view. For 
instance, at the close of the third act, I have introduced the principal square of the city during the grand festival of Raymi, the most magnificent and imposing of all the Peruvian religious ceremonies, which was solemnized with feasting, dancing, music, and song. On this occasion, when the Grand Luminary was worshipped as a visible god, chiefs, princes, and people, male and female, of every rank, assembled in countless multitudes, and marched in procession variously attired. Some wore the skins of animals, some appeared as angels, with wings of the condor, some in horrible masks threw themselves into postures like maniacs, while others displayed their characteristic ornaments and warlike arms. High above the joyous crowd, borne on the shoulders of his subjects and seated in his golden chair, came the monarch, prepared to pour out the consecrated wine as a libation to the deity. All advanced to greet with profound admiration the rising sun, which, having arrived at the farthest point of its meridianal career, began to retrace its course to the north. Long and loud were the shouts of joy, songs of triumpl, and bursts of clamorous music, when the first rays gilded the summits of the neighbouring mountain range, and the excited multitude inhaled the atmosphere impregnated with light. As we possess little information respecting 'Quito' (the place named by the dramatist), the interior of the temple, in the second act, and the view of the city in the third, are taken from the descriptions so amply given of ' Cuzco,' the ancient capital of the cmpire, once the scene of so much glory and magnificence.

"The Indian airs introduced into the music are founded on melodies published in Rivero and Tschudi's work on 'Peruvian Antiquities,' as handed down to us by the Spaniards after their conquest. 
"By the revival of 'Pizarro,' long known as a most attractive play, I cannot but think that a wide field is afforded for the introduction of that historical detail which lends new interest to theatrical art. The present age demands that all dramatic representations must of necessity be accompanied by a certain selection of scenery, dresses, and music. The public voice has justified me in deciding that truth in these matters is preferable to inaccuracy. Hence I conclude, that when an appropriate opportunity is embraced of blending instruction with amusement, when the mind may be informed while the eye is gratified, the drama is not likely to lose or be degraded by the attempted association."

"Pizarro" was first acted at Drury Lane, on the 24th of May, 1799; too late in the season for the necessary xun, which ended on the thirty-first night when the theatre closed. Neither dıns from without, nor the bankrupt state of the exchequer, could rouse Sheridan to finish the play in time. He was unacquainted with German, and worked from previous Euglish translations of Kotzebue, of which there were three or four," although none had been acted. The literary pretensions of "Pizarro" are certainly not of a higl order, and have been reduced by some writers to a contemptible standard. A story is told that, during the season when the "Castle Spectre" filled the exhausted treasury of Drury Lane, Sheridan and Monk Lewis (as he was called), the author, had some dispute in the green-room, when the latter offered, in confirmation of his arguments, to bet Mr. S. all the money which the "Castle Spectre" had brought, that he was right. "No," replied the manager, "I cannot afford to bet so much as that; but I will tell

* By Miss Plumptre, M. O. Lewis, and Heron. 
you what I will do, I'll bet you all it is worth." The witticism was as rich as it was ungrateful, and might have justified a similar retort from the Monk in the case of "Pizarro." Between the two plays it would be difficult to settle the point of inferiority.

No speech was ever better calculated to entrap applause than Rolla's address to the soldiers, which is entirely Sheridan's, and not in the original. It was evidently intended as a taking reference to the war with the French Republic, and a philippic against the principles of the Revolution; yet nothing is said which might not with equal propriety be addressed to an army of Peruvians. Such was the popularity of this tragedy, that the King, George III., could not resist his desire to see it. He had ceased to visit Drury Lane for several years. Many causes have been assigned for his absence from that particular theatre, some sufficiently absurd; such as a personal dislike to Sheridan, because he was a Whig, a partisan of Fox, and an intimate associate of the Prince of Wales; but the most probable reason was, that he had commanded two pieces, which, on account of the complicated machinery, could not be acted on the same evening, unless he should wait two or three hours between the play and the farce. The intimation of the difficulty was given in a manner not considered as consonant with court etiquette.

The juniors of the present generation who had never seen "Pizarro" until now, had often heard their fathers speak of John Kemble and Mrs. Siddons in Rolla and Elvira; of the glories of the Temple of the Sun, and of the peals of applause that attended the delivery of the Peruvian leader's far-famed oration to his army. There was fine acting in those days, and splcndour and scenic pageantry, too, after a.certain 
fashion; but there was little attempt, at historical truth; no multitudes to fill the stage, no studied groupings, and no complicated action, in which every supernumerary engaged had a part to play, as essential to the completeness of the general picture, as the imposing attitudes and declamation of the hero or heroine. Instead of addressing an assembled nation, Rolla spoke to some dozen and a half of discharged veterans, who reminded the audience of the Pope's body-guard, described by Voltaire as old ladies who mount guard with umbrellas, and make war on nobody. They stood on each side of the stage, ranged in single file, with changeless aspects, and shouted feebly at the close of the general's harangue, without movement of limb or feature. Pizarro's tent, with which the play opened, resembled the gorgeous pavilion of a Persian satrap, and was large enough for the residence of Tippoo Saib and his harem. There lay Elvira on a sumptuous sofa, with a regal tiara, an embroidered robe, and an interminable train of crimson velvet, which swept the stage as she rose and moved across with measured, queen-like steps. In the German play, Elvira is habited as a page, in male attire, but this was a dress that Mrs. Siddons refused to wear. We remember, too, the lasting impression made on our boyish fancy by the miraculous transit of a ball of lighted tow, which descended upon the altar, in the temple scene, by means of an invisible wire; and how Rolla, to bribe the sentinel, produced from under his cloak a modern red-morocco jewel-case, similar to that which ladies lay upon their dressing-tables. There were many other monstrous incongruities, but they passed without notice, for the age had not then been impressed with the conviction that " truth in such matters of detail was preferable to inaccuracy." 
The most objectionable point in the original arrangement of the play, was the ill-contrived and almost ludicrous manner in which retributive justice was dealt on Pizarro, who, after being bullied through five acts by Alonzo, Elvira and Rolla, in succession, was killed unfairly in the end; as Porson commenorates in his amusing parody :-

" Four acts are tol, lol ; but the fifth's my delight, Where history's trac'd with the pen of a Varro ; And Elvira in black and Alonzo in white Put an end to the piece by killing Pizarro."

It is but just to the memory of Kotzebue to remark that this gross departure from historical fact was a gratuitous interpolation by Sheridan, a compliance with what was then the prevailing taste of the play-going public, dragged in to excite the plaudits of the gallery, and to foreshadow the fate of the invader with whom England was menaced. Every schoolboy might hảe known and remembered that Pizarro lived to conquer Peru, and was finally assassinated in his viceregal palace at Lima, by the son and friend of his early associate, Almagro, whom he had executed some years before. The omission of this fictitious episode in Mr. Kean's new arrangement, removed what had always been considered an impediment and error, by continuing the action after the death of Rolla. It was a skilful exercise of the callida junctura which denoted clear critical perception, and sound managerial judgment.

A comparison between Mr. C. Kean's printed version, and the earlier one of Sheridan, will show at once the value and amount of the alterations and introductions. The most important of the latter are the military chorus, and march of the Spanish troops at the 
end of the first act, and the grand Peruvian festival of Raymi, which winds up the third. The gradual approach of the rising sun, with the effect of the expanding beams in this scene, and the earlier one of the sacrifice in the temple, was gorgeous, imposing, and novel beyond all precedent. The return of the Peruvian army in triumph from the battle, with the accompanying gratulations of their wives and children, suggested reminiscences of the recent national demonstration, when the surviving heroes of the Guards, on their return from the Crimea, marched through the streets of London. The management of Rolla's escape with Cora's child, was another point that utterly bewildered the audience. Instead of the oldfashioned mode of cutting down a rustic bridge, that looked as if arranged for the purpose, he swung himself by the pendent branch of a tree across a tremendous chasm, and being mortally struck by the musketry of the Spanish soldiers, in the passage, was seen staggering through the rocks and glades until he disappeared in the distance, the effect of perspective being carried out by a duplicate figure of smaller size, which gave rise to endless conjectures and arguments as to how this optical delusion could be contrived.

Mrs. C. Kean could never have seen Mrs. Siddons in Elvira, or she might have involuntarily moulded her conception upon that of such an illustrious predecessor. This fortunately was impossible, and has given us an original portraiture, instead of an imposing copy. Mrs. Siddons looked and moved thè tragedy queen, with an innate air of regality she could never entirely forget. She was statcly, grand, impressive, tremendous; but she lacked flexibility, and it was difficult to associate with her the idea that she was a 
being who could be led by ardent feeling into a position of subserviency to a spirit inferior to her own. Mrs. C. Kean was more like a warm-hearted, impulsive woman, governed by excited imagination, more full of feminine sympathy, and, if we may be permitted to carry out the antithetical comparison, less fearful, but more agreeable. In her hands the character became softened without being rendered weak. She represented Elvira as goaded and perverted by insult rather than by injury. The distinction is as true to nature, as it is clearly conveyed. "I have suffered at the hands of Pizarro," she says to Rolla, "as deeply as scorn and insult can infuse their deadly wounds." Her demeanour and conduct bear out what Junius has so truthfully laid down as an axiom in the complications of the human heart:- "Injuries may be atoned for and forgiven, but insults admit of no compensation; they degrade the mind in its own esteem, and force it to recover its level by revenge."

Rolla is a more amiable stage creation. He may be unnaturally perfect, but he is infinitely interesting. He moves through the play the cynosure of universal admiration. Every eve looks on him with delight, and every ear greedily catches his accents. How angry we feel with Cora for her preference of the comparatively tame Alonzo. Mr. C. Kean appeared to great advantage in this noble impersonation, than which nothing could be more opposite to his Wolsey, Hamlet, or Louis the Eleventh. He, too, like his accomplished partner, must have studied exclusively from his own ideas. John Kemble died long beforc he became an actor, and Young, the legitimate successor of the first Rolla, retired while Charles Kean was yet in his early novitiate. Rolla was never amongst lis father's acknowledged characters, and, on the few occasions when he performed it in vOL. Ir. 
London, the play was either slurred over, or cooked up in a hurry for a benefit.

Pizarro is one of those thankless tyrants who require an imposing appearance, with a dauntless, determined bearing; a type of selfish ambition, as opposed to disinterested patriotism. A more faithful reflection of this stern warrior could not have been given than by Mr. Ryder. Cooper was impressive in Orozembo; and Miss Heath displayed much tenderness in Cora. The scenery reflected the highest credit on Mr. Grieve and his able assistants. The glowing luxuriance and warmth of South American vegetation were transferred to the canvas with the delicate finish of the richest cabinet painting.

On the 15th of October, 1856, before the attraction of "Pizarro" had begun to wane, "A Midsummer Night's Dream," was produced. This beautiful emanation of Shakespeare's fancy may. be considered, perhaps, the most exquisite specimen of graceful, imaginative, and harmonious composition that the mind of a great poet has ever conceived, or his pen transmitted to posterity. The prying investigation of commentators has tortured itself in vain attempts to discover any direct source or popular story from whence Shakespeare derived or constructed his drama. All that they have been able to burrow out amounts to the coincidence of a few names which have been met with before, and a very slight similarity between his fairies and those introdnced in Michael Drayton's fantastical poem of "Nymphidia." These frivolous disparagements have been hypercritically set forward to detract from the original conception of the most universal and discursive genius ever enclosed within a human form; a genius which, with the swiftness of thought, conld traverse and surpass the boundaries of the universe, control space and time, and in the words of his own Puck, "put a girdle round about the 
earth in forty minutes." When Shakespeare wrote for the emergencies of the theatre, he borrowed his subjects from familiar tales, legends, or chronicles; when he composed from pure inspiration and poetic impulse, he drew upon his own exhaustless invention.

Garrick, when he revived "A Midsummer Night's Dream " at Drury Lane, in 1763, omitted many of the most poetical passages, which are so profusely scattered through the play that they supply more standard quotations than almost any other single production of the same author. The manager also supposed that as fairies are generally associatcd with the idea of tiny, diminutive elves, it would be a happy thought to have Oberon, Titania, and their attendant courts and familiars, represented by small children. The conception was a mistake, and the experiment a failure. The piece, thus metamorphosed, was acted only once, to a thin November audience who were cold and drowsy. Respect for Shakespeare kicpt them silent, but that silence also induced them to follow the example of the four lovers, who in one scene are all discovered lying fast asleep on the stage. Shakespeare has endowed the fairy monarch and his queen with the language, feelings, sentiments, passions, and jealousies of matured humanity. They speak, think, and act like real men and women, reminding us of Cupid, no longer the mythological infant, but the lover and husband of Psyche. None of the attributes given to them could be adequately conveyed through the puerile organs of childhood. Consistency might to a certain extent be imparted to the eye, but it was lost to the intclligence. Shakespeare's fairies delight in the moonlight revel on the noiseless grass; they are shadowy, etherial, bright, elastic essences, gifted with supernatural power and refinement, continually mixing themselves up with the affairs of mortals; but we cannot figure then 
to our minds as bearing any resemblance to the lilliputian, household imps, so inseparably connccted with our nursery fables and recollections.

It has been said, too, that the play is deficient in dramatic interest; that the lovers are tame, and that Theseus and Hippolyta do nothing. Assuredly it is not intended to embody a history of deep, concentrated passion. There is no design of harrowing up the soul, and of conveying the fearful lessons which are taught bv "Othello," "Macbeth," or "Lear." To look for violent, conflicting action, and collision of opposite character, where the scene passes the boundaries of common nature, and the chief actors are etherialized beings, flitting through boundless space, is to expect them where they can never be found, except in the incongruous tales of eastern enchantment. The interest and incidents of Shakespeare's play amply suffice for the purpose in view, and he has combined them with the hand of a great master, and with skilful variety to produce what he designed,-a fairy drama, A Ifidsummer Night's Dream. If the mortals introduced had been rendered more prominent than the mythological agents, the entire construction and object of the play would have been subverted. Shakespeare knew better than his critics when, where, and how to bring his resources together, and to balance them so as to preserve that just harniony of proportion, which marks one of the most delicate distinctions between ordinary ability and exalted genius.

Very few of Shakespeare's immortalitics have been so unmercifully subjected to the transmuting process of the crucible as the "Midsummer Night's Dream." As far back as the return of Charles II. (in 1661), a comic actor named Cox, celebrated for a peculiar class of drolls and farces, added this magnificent conception to the list of his mummeries, or rather a part of it, under 
the title of the "Humours of Bottom the Weaver." About thirty years later (1692) it became an opera, and was called the "Fairy Queen." In 1716, a drunken bass singer, Leveridge by name, changed it into a masque, entitled, "Pyramus and Thisbe," from which it became a mock opera in 1745 , the music being supplied by a composer named Lampe. Ten years later, Garrick produced it as "The Fairies," with Italian singers. Colman repeated a similar experiment in 1777 ; and, in 1816 , it was presented as a musical play at Covent Garden, with alterations and additions by Frederic Reynolds. The interpolations of the last-named writer, wound up with a grand pageant, commemorative of the triumplis of Theseus; which same triumphs have no more connexion with the incidents and progress of the original drama, than a panorama of the battle of Waterloo. Theseus himself is only a subordinate pivot, or indicated point to connect the story. During Madame Vestris's management at Covent Garden, the true Shakespearean version was restored, proving one of her most attractive cards. Mr. Phelps also included it in his list at Sadler's Wells. The two latter restorations deserve to be mentioned in terms of the highest praise; they werc stcps in the right direction, although the palm of superiority must be assigned to the still more recent revival by Mr. Kean, of which we are now speaking.

In the "Midsummer Night's Dream," which is almost exclusively a creation of fancy, there is scarcely any scope for that illustrative and historical accuracy, or for that classical research, so peculiarly identified with Mr. Kean's system of management, and witl which his name had now become almost synonymous : nevertheless, he availed himself of the few opportunities afforded by the subject, of carrying out his favourite 
plan. So little is known of Greek manners and architecture in the time of Theseus, twelve hundred years before the Christian era, and so probable is it that the buildings were of the rudest form, that any attempt to represent them on the stage would have failed in the intended object of profitable instruction. Holding himself, for these reasons, "unfettered with regard to chronology," Mr. Kean presented ancient Athens to us, in the opening scene, at the culminating period of its magnificence, "as it would have appeared to one of its own inhabitants at a time when it had attained its greatest splendour in literature and art." His scholastic taste took advantage of the specified scene of action, to place before the eyes of the spectators, on the rising of the curtain, a restored view of that famous city, "standing in its pride and glory," which excited the spontaneous sympathy, and called up some of the earliest and deepest impressions of every educated mind. We saw, on the hill of the Acropolis, the far-famed Parthenon, the Erichtheum, and the statue of the tutelary goddess Minerva, or Athena; by its side the theatre of Bacchus; in advance, the temple of Jupiter Olympus, partially hiding the hall of the Museum; and on the right, the temple of Theseus. The view also included the summit of that memorable eminence, "from whence the words of sacred truth were first promulgated to the Athenian citizens by apostolic inspiration."

Nothing could exceed the consistent harmony with which all the varied elements of the play were blended together. The introduction to the haunt of the supernatural beings; the first appearance of Oberon and Titania, with their attendant trains; the noiseless footsteps of the dance on the moonlit greensward, with the shadowed reflection of every rapid and graceful movement; the wood peopled with its innumerable fairy 
legions, whose voices lull their queen to sleep upon a bank of flowers; the melodious music composed by Mendelssohn to the words of the author, in a strain and tone of feeling in intimate sympathy with the subject; the pcrpetual change of scene and incident; the shifting diorama; the beams of the rising sun glittering on the leaves; the gradual dispersion of the mist, discovering the fairy guardians, light and brilliant as gossamer, grouped around the unconsciously sleeping mortals; the dazzling magnificence of the palace of Theseus at the close, thronged on every staircase, balustrade and corridor, with myriads of aerial beings, who join in an unseen and unheard epithalamium on the mortal inmates who have retired to rest; - these, in an endless succession of skilfully-blended, pictorial, mechanical, and musical effects, overpowered the faculties of the spectators with the influence of an enchanting vision. Written description can convey but a faint idea of the glowing, animated reality. The monotonous feelings of every-day life were forgotten, and we woke after a three hours' journey into another world, as if from the recollection of a delicious dream. What more convincing evidence could be given of the potency of the spell than a mention of the fact that "A Midsummer Night's Drcam" was repeated for one hundred and fifty nights during this and the following season.

The actors ought not to be forgoten. The play contains no character suited to the abilities of Mr. and Mrs. C. Kean. Theseus of Athens, and Hippolyta, his Amazonian queen, take the lead amongst the human personages. Hifpolyta says little, while Theseus has only to look heroic, and speak some fine passages of poetry, never omitted in selections from the " beauties of Shakespeare." Both were spleudidly impersonated by Miss Murray and Mr. Ryder. Miss Heath and Miss Bufton, as Helena, 
and Hermia, were beautiful to gaze upon. Miss Fanny Ternan made a highly successful first appearance as Oberon, and Miss Carlotta Leclereq acquitted herself with bewitching grace as Titania, the Fairy Queen. The progress of this young lady may be quoted as a remarkable evidence of the excellent training of the Princess's Theatre. In six years, from a member of the corps de ballet, she became one of the most accomplished and versatile comic actresses of the present day. Another presented itself in the precocious talent of Miss Ellen Terry, a child of eight years of age, who played the merry goblin, Puck, a part that requires an old head on young shoulders, with restless elfish animation, and an evident enjoyment of her own mischievous pranks. For Bottom and his brother operatives, the "hard-handed" men of Athens, who gratify their own vanity and amuse their superiors with the tragic mirth of "Pyramus and Thisbe," we had Harley, F. Matthews, Meadows, Saker, and F. Cooke. These rich comedians carried off the underplot and relief of the play with exquisite fooling. Harley in particular, presented a variety in the line of originals in which that worthy scion of the old school had long been without a rival. His acting was, in fact, a school of itself which baffled imitation and died with its master.

On Tuesday, the 18th of November, an amusing and well-constructed after-piece, in two acts, was produced, entitled "Our Wife; or the Rose of Amiens ;" in this we recognized an adaptation (by Mr. J. M. Morton) from a French operatic play, acted in Paris some sixteen years ago, at the Opera Comique, called "La Rose de Peronne," but not until now transplanted to the London stage. The experienced English dramatist condensed his materials with good taste and skill. Our volatile neighbours, in the intricacies and ingenuities 
of plot, and the combination of unexpected effeets, possess a certain superiority of constructive art which we readily imitate and acknowledge, but seldom equal. Yet mixed up with their best plays there is usually some leading objection on the score of morality, something that offends English propriety and delicacy; a series of calamities arising from the eccentric indulgence of unsanctioned passion. Writers of this persuasion appear to think that an audience cannot be excited except by strong pictures of depravity and representations of "three piled" vice, which, for the honour of human nature, we hope and believe to be the exceptions rather than the rule. Hence the outery which always accompanies the production of a drama of this class, although sometimes without diminishing its attraction. For a nation that professes decorum, and winees at immorality, we should be a little more consistent. The moral poison of the Dame aux Camelias was refused a licence when presented in sturdy out-spoken English; but when by alchemic process it became transmuted into Italian melody, it was permitted to diffuse itself without let or limit. In the "Rose of Amiens" there was no taint of this besetting sin. All was light, humorous, entertaining, exciting, and interesting, without a line in the dialogue or an inference in the plot and action, that could offend even an audience of puritans. This pleasant little comedy commanded thirty-three repetitions, and was only laid aside for the pantomime, founded this year on the old Arabian Nights' tale of "Aladdin and the Wonderful Lamp." 


\section{CHAPTER X.}

REVIVAL OF KING RICHARD THE SECOND BY MR. C. KEAN-PREVIOUS ALTERATIONS OF THIS PLAY, BY TATE, THEOBALD, AND WROUGHTON-INVARIABLE WANT OF ATTRACTION-ATTRIBUTED TO THE ESSENTIALLY ONDRAMATIC NATURE OF THE SUBJECT-EDMUND KEAN IN RICHARD THE SECOND, AT DRURY LANE, IN 1815-MACREADY, IN THE SAME PART, AT THE HAYMARKET, IN 1851-SUMMARY OF THE PLAY, AND NEW EFFECTS, AS PRODUCED BY MR. C. KEAN-HIS ACTING AS THE KING--MRS. C. KEAN AS THE QUEEN-THE PLAY RONS FOR EIGHTY-FIVE NIGHTS WITHOUT INTERMISSION - GENERAL REMARKS-REVIVAL OF THE TEMPEST-CLOSE OF THE SEASON-TWO HUNDRED AND FORTY-TWO SH. KESPEAREAN REPRESENTATIONS.

JoHn, Duke of Marlborongh, a man of action rather than a reader, and of very limited education, was often heard to say that he derived his chief knowledge of history from witnessing the representations of Shakespeare's plays. Yet in his day he could only have seen the great magician imperfectly reflected in the mutilations of Gildon, Dennis, Nahum Tate, Colley Cibber and Co., with the "Macbeth" and "Tempest" of Dryden and Davenant; in all of which the name of the author was preserved, while the strength and beauty of his poetry were nearly suffocated. Had the great duke lived in the present age, and witnessed Mr. C. Kean's genuine revivals at the Princess's Theatre, his notions of Shakespeare and English chronicled history would have been much nearer the truth; and he would have hailed a revolution in literary and dramatic taste as extraordinary, as the political changes to which he so largely contributed. 
" Richard the Second," from the true text of Shakespeare, was produced at the Princess's on the 12 th of March, 1857. Mr. Kean, in a clear and ably written preface to the published book, while detailing his list of authorities, and thanking the zealous antiquaries who had seconded his own researches, reiterated what he had declared before; namely, that his leading object in the Shakespearean revivals was to preserve the language of the author inviolate; to embellish his magnificent conceptions with all the accessorial aid of pictorial and mechanical appliances; to resuscitate history whenever the opportunity presented itself, even to the most minute details, so that every scene should be a text to lecture on; and to base ali that he presented to the spectator on unimpeachable authorities. It need not be asked, how is it possible that the dramatic art, with its multiplied resources and extended influence could be more nobly employed, or how could the memory of the greatest poet that ever breathed, be more honourcd and exalted? There can be but one answer, except from the narrow nil admirari critics, who find all barren "from Dan to Beersheba;" who walk the world perpetually writhing and sneering, disappointed and bilious, vexed at the success of their neighbours, and who never knew the luxury of an honest burst of exultation, or joined in a heart-springing round of applause. And fortunate it is for the drama, that these jaundiced cavillers are in a powerless minority.

Steevens, the celebrated Shakespearean commentator and editor, says, in a note appended to the "Yorkshire Tragedy" (one of the scven spurious plays), and in his edition of 1793 ,- " The critics may applaud " Richard the Second," though the successive audiences of more than a century have respectively slumbercel over it as often as it has appcared on the stage. Garrick had 
once resolved on its revival, but his good taste at last overpowered his ambition to raise it to the dignity of the acting list." If Garrick had laid his fingers on this play, we should have had as many un-Shakespearean additions and alterations in the text, as he had been guilty of in "Romeo and Juliet," "Hamlet," the "Winter's Tale," and the "Midsummer Night's Dream." On this point he was possessed with a caco-damon, and fancied it the spirit of the Bard of Avon. Nahum Tate, in 1681, metamorphosed "Richard the Second" into a thing called the "Sicilian Usurper," changing the time, place, and incidents, as well as the language. This farago was stopped on the second night by the authorities, not for its demerits or desecration of Shakespeare, but because they thought it dangerous to allow the public to witness successful rebellicn. Theobald (the dethroned hero of Pope's "Dunciad") in 1719 produced another monstrous travesty at Lincoln's-Inn-Fields, which ran for seven nights, and obtained for the mutilator a purse of one hundred guineas from Lord Orrery for a fulsome dedication. In 1738, a third version was tried at Covent Garden, chiefly remarkable for the performance of "tall Johnson," as he was called, the sonin-law of Aaron Hill, who was selected for John of Gaunt, because he was bony and burly, and his stature approached seven feet. Then the play slumbered for seventy-seven years, until,in 1815, the Drury Lane Committee employed their stage-manager, Wroughton, to hash it up for Edmund Kean; the said Wroughton being a heavy actor, and a heavier scholar, with as little of the Shakespearean inspiration as could be expected from leaden mediocrity. Strangely fantastic were the tricks which this play-wright was allowed to play with his subject. The touching and naturally-flowing rhymes, so characteristic of the early compositions of the author, 
and so peculiar to the age in which he wrote, were laboriously and pedantically altered to halting blank verse; scenes were interpolated bodily from the disjecta membra of several other plays; new speeches were written, in justification of which, Colley Cibber on "Richard the Third" was pleaded as a precedent, but without his happy ingenuity; Bolingbroke delivered a panegyric on thriving ambition, from Aaron the Moor, in "'Titus Andronicus;" and the Queen, who had been despatched by Shakespeare to France, in accordance with historical fact, was made to rush in frantically to the dungeon at Pontefract, and expire on the body of her murdered husband.

All this (shall we not call it sacrilege?) and more, was sanctioned in full council by a committee of erudite lords and members of the lower house, who then held the sceptre of Drury Lane in commendam; all this Shakespcarëcide received the fiat of the public, to a ccrtain cxtent, and was perpetrated, morcover, at the precise period which after-dinner orators at charitable festivals, and before the plate goes round, delight in glorifying and bewailing as "the palmy days of the drama." Edmund Kean did wonders with the part of the deposed king. Many are still living who remember how that bright genius struggled to emancipate Shakespeare from the heavy dross with which he was clogged; what startling effects he produced, particularly in the third act; but how, at the same time, no permanent attraction could be elicited from such an ill-assorted mixture. In the arrangement there was little thought bestowed on the author, and none on the truthfulness of history. Not even the powers of a Kean conld restore permanent life to a play in which the vital principle had been so cruelly reduced. After ten or twclve repetitions it ceased to be inquircd after. 
Time rolled on, and in $1851 \mathrm{Mr}$. Macready appeared twice as Richard the Second, at the Haymarket, a few weeks only before he retired from professional life. It was scarcely worth his while to venture a new part on the eve of abdication. The play was then acted from the text of Shakespeare, but not, in stage phraseology, "got up," and its immediate withdrawal indicated a very qualified approbation. The tone of criticism in some of the most favourably-disposed journals, implied directly that the want of success was owing to its being essentially undramatic, although, in some respects, a fine poem; - a singular dictum, when we call to mind that Shakespeare wrote exclusively for the stage, without thinking of the study or the lecture room.

We have here enumerated all that the London public have ever seen of "Richard the Second," on the boards," within the memory of the living generation. Thus, as it will appear, the subject came fresh and vigorous into the hands of Mr. Charles Kean.

" Richard the Second," as represented at the Princess's Theatre in 1857, opens in the Privy Council Chamber at Westminster, with the quarrel of Bolingbroke and Norfolk, in the royal presence, and the King's appointment that they shall decide the question by single combat. After a short dialogue between the widowed Duchess of Gloucester, who suspects Norfolk of having contrived the murder of her husband, and John of Gaunt, in the Savoy Palace, close to the Strand, the scene shifts to the lists at Gosford Green, near Coventry; and here we are presented with a passage of arms according to the usages of ancient chivalry. The antagonists are mounted, their spears in rest, the trumpets sound the charge, and they are rushing to engage with

* There was an alteration by a certain W. Goodall, resident in the classic regions of Manchester, printed in 1772, but never acted. 
the impetuosity of mutual hatred, when the King throws down his warder, suspends the duel, and banishes the challenger and challenged. Had the fight proceeded, and Mowbray by good fortune killer his haughty appellant, Richard might never have lost the crown, the tragedy at Pontefract would not have darkened our annals, and the subsequent history of England would have detailed a different series of events.

The dying chamber of old " time-honoured Lancaster," in Ely House, Holborn, commences the second act ; the bed, the paintings on the walls, the furniture, and all the appointments of the room, being scrupulously copied from authorities beyond dispute. We hear the indignant reproaches of Gaunt, and his uuheeded advice to the thoughtless monarch, with the angry replies of the latter, followed by the arbitrary appropriation of his uncle's vast possessions, as soon as he has ceased to breathe. The King then departs for the Irish wars. Up to this point of the play, the character of Richard is merely introductory, affording no scope to the actor and exciting no interest with the audience. He has proved himself an unjust steward, and prepares the way for his own subsequent calamitics.

The Queen is now introduced, at the entrance to $\mathrm{St}$. Stephen's Chapel. Shakespeare, for the sake of heightening the interest of his play, has deviated from historical truth, by representing Isabella of Valois as a wouran; when espoused by Richard, she was a child, not nine years old. There is no evidence to show that she ever saw him after his departure for Ireland. She had searcely reached ten when he was slain. Henry the Fourth, after some time, allowed her to return to France, when she married the Duke of Orleans, and died in her twenty-second year, September 13th, 1410.

As the Queen leaves the stage with the Duke of York 
who presents, without questioning his suspicious loyalty, a most incompetent viceroy in troublous times, we pass to a most beautifully painted landscape in Gloucestershire, through the forest glades of which the army of Bolingbroke advances, in the full panoply of war, confident in their leader, and glowing with the pride of anticipated success. "In the mareh of that formidable and unopposed host through the heart of the country, casting their ominous shadows before, we read the approaching downfal of the absent king.

As the curtain rises for the third act, Richard lands from Ireland at Milford Haven; but has scarcely time to express his joy at once more treading the soil of his own kingdom, when he feels the sceptre gliding from his hands. At every moment he receives tidings of the rapid approach of his rival, and the desertion of his friends. Now the dramatic pith of the character begins to unfold itself. The abyss is yawning beneath his feet, and the sudden discovery prostrates his manhood. The accumulation of misery wrings his soul with agonizing grief. He has no philosophy, but he ean feel and suffer acutely the impending degradation. $\mathrm{He}$ is a man, though a weak and erring one, and we forget lis faults in his misfortunes. Shakespeare has made his poetical Richard utter precisely what we can conceive the real Richard to have given vent to, in that situation; and most impressively were the speeehes rendered, and the conflieting emotions eonveyed, in tone, gesture, and expression, by his living representative. We recollect nothing finer than Mr. Kean's acting throughout this entire scene, except perhaps his climax in the next, when he comes forth from Flint Castle, and surrenders to Bolingbroke. The latter kneels and tenders obeisance in mock humility. Richard struggling with his indignation, replies,- 
"Fair cousin, you debase your princely knee,

To make the base earth proud with kissing it :

Me rather had my heart might feel your love,

Than my unpleas'd eye see your courtesy.

Up, cousin, up ; your heart is up, I know,

Thus high at least, (touching his oron head)

although your knee be low."

The burst of natural passion with which Mr. C. Kean worked up this speech, and the effect he produced upon the audience, almost persuaded those who remembered his father in the same passage, that they saw him standing bodily before them, in the person, and reflected in the mind of his son.

Bolingbroke, now virtually king, proceeds to the metropolis, accompanied, or rather attended by the captive Richard. All readers of Shakespeare, from their schoolboy days, are familiar with the often-quoted description of the entry of the two cousins into London, so pathetically described by their uncle York to his Duchess, in the latter portion of the play. This was declared by Dryden, a jealous critic, to be a sublime passage of dramatic poctry superior to anything in Sophocles or Euripides, and which left the moderns, without cxception, at an immeasurable distance. Mr. C. Kean here seized the boldest idea, and transferred to the scene the most graphic Shakespearean illustration that ever entered into the mind of actor or manager : an illustration that gave a reality to the play it was never supposed to possess. Hc embodied and anticipated the description of York, in an episode of action, introduced between the third and fourth acts, carrying on the story, connecting the chain of crents, and preparing the spectators for the solemn abdication of Richard which immediately follows. The contrast of feeling and position between the falling and the rising monarch is thus brought out in masterly relief. This episode was pronounced by thousands who witVOL. II. 
nessed it on repeated occasions, to be, beyond all comparison, the most marvellous scenic illusion that had ever been attempted. If a citizen of London, at 1399, could have been actually revived, and seated within the stalls of the theatre without passing through the changed external world, he would have fancied that he saw a living repetition of what he once had taken a part in. There could not have been less than from five to six hundred persons on those contracted boards, all moving in trained regularity or organized disorder, according to the varying incidents. The music, the joy-bells, the dances, the crowded balconies and windows, the throngs in the streets, the civic processions, the mailed warriors, the haughty Bolingbroke, the heart-broken Richard, the maddening shouts of gratulation which attend the one, while the other is received with silence, gradually deepening into murmurs, groans, and insults, the scrupulous accuracy with which every dress and movement is pourtrayed;--all this completed a picture which brought back the past to the eyes of the present, and bewildered the spectators with a mingled sensation of astonishment and admiration. The scene altogether surpassed the glories of Wolsey's banquet and ball in "Henry the Eighth," or the maddening reality of the Dionysian pastime in the "Winter's Tale." The spell was rendered still more potent by the knowledge that we saw passing before us the resuscitation of a memorable passage from our own domestic chronicles.

The pomp and bustle of the episode in the streets of London, prepare the audience for the touching solemnity of Richard's abdication in Westminster Hall; which, with a short preceding scene of the Queen with the Gardener at Langley, the Duke of York's country residence, occupies the fourth act. Here again the acting of Mr. C. Kean had its full play, riveting 
the attention of the audience, and dividing their expressions of satisfaction between tears and applausc. The effect produced in this part of the tragedy, which depends entirely on the actor, proved beyond denial, how the poetry can retain its full value distinct from the surrounding pageantry, and how its power is increased rather than obscured or weakened by accessorial relief.

The fifth act opens before the Traitor's Gate at the Tower, with a pathetic farewell between Richard and his Queen. This scene affords Mrs. C. Kean the only opportunity a very insignificant part allows of showing that such talent as hers can create material out of almost nothing, and that the impression which a finished artist can produce, is not dependent on the amount of words she has to utter. The features, the mind, and the heart, are potent movers, even when the tongue has little to express.

The play now rapidly hastens to a conclusion. In the gloomy dungeon at Pontefract the crime is perpetrated, the body of the murdered Richard is laid before Bolingbroke, in St. George's Hall, Windsor, while he sits in state, as King, attended by the nobles of the land, surrounded on the steps of the throne by his four sons, in the plenitude of his porrer and triumpl. In that proud hour, when all his worldly hopes are realized, remorse touches his soul, the moral is consummated, the history is complete, and the curtain falls.

All the dry reading of the closet, the old black-lettcr tomes of Holinshed and Hall, the multiplied rolumes of Rapin, Tindal and Hume, would fail to impress the mind with such a truthful and lasting impression of any given passage in our English annals, as that conveyed by a single play of Shakespeare, as placed upon the stage of the Princess's Theatre during Mr. C. Kean's 
management. Never was a great problem more completely solved by the result.

Old play-goers often remark, and old actors complain, that modern audiences are less enthusiastic in the outward and visible tokens of their delight; less given to applaud than were their fathers and grandfathers. The fact is apparent. Hence it is inferred (somewhat hastily) that acting has degenerated, and dramatic taste become less fervid. We suspect the converse of both conclnsious to be nearer the truth. Education, refinement, and general knowledge, have rendered all classes more exacting. It is not so easy to astonish as it was formerly. Thirty or forty years ago, the great idol of the day made insulated points, at which the pit stood up, and the house vociferously cheered. It was the actor they went to see, rather than the play; and when he was not on the stage they yawned, for there was little then of collateral aid to excite sustained attention. At least half the entertainment operated as a soporific; there was no succession of pictures, no resuscitation of actual manners and persons as they existed in bygone times; no accuracy of detail in unimportant as well as in the more prominent scenes; and no effort to present a consistent whole, instead of a dazzling portion. Mark what Shakespeare himself says in this identical play of "Richard the Second":-

\footnotetext{
"As in a theatre, the eyes of men, After a well-grac'd actor leaves the stage, Are idly bent on him that enters next, Thinking his prattle to be tedious."
}

This shows distinctly that in his early day (and the application holds good to a much more recent period), the speciators thought little of the drama itself, and had no perception of the powcr with which pictorial 
and mechanical art could be called in to relieve, vary, and enhance the effect of impressive acting. We know no instance in which the fact has been so thoroughly established as in Mr. C. Kean's performance in the third and fourth acts of "Richard the Second," in which the dramatic essence of the character is concentrated. The most exceptious critics have admitted that in this arduous delineation there was no mannerism, no imitation of any style, no exaggeration, nothing artificial or laboured; the veritable Richard stood, moved, and spoke before us, with all his wounded pride, his mortified sensibility, his wrongs, his woes, and his dearly expiated follies;-as transferred from the pages of the historian, warmed and coloured by the imagination of the poet, and called into re-animated existence by the kindred genius of his interpreter.

Mr. and Mrs. C. Kean were ably seconded by Mr. Ryder, who both looked and acted well as " the mounting Bolingbroke." Mr. Cooper and Mr. Walter Lacy deserve similar commendation as the Dukes of York and Lancaster.

On the evening of the 13th of May, 1857, during the performance of " Richard the Second," an accident occurred, which threatened the destruction of the theatre, with the loss of maly lives. Providentially, the impending calamity was averted. As the velvet curtains, used instead of the usual drop scene, were withdrawn for the fifth act, they suddenly caught fire from the gaslights at the side. The material being of the most combustible nature, ignited with incredible rapidity. The conflagration spread over the borders above, and in a moment the whole of the proscenium was in flames. The audience began to rise, and if a sudden rush to the doors had taken place, as has sometimes occurred upon a similar alarm, it is fearful to reflect on what might have occurred. Mrs. C. Kean, who was discovered on the 
stage in her place to commence the act, came instantly forward with the most perfect self-possession, assured the audience that there was nothing to apprehend, that the fire was only momentary, and would be subdued at once, entreating them to sit still. Her presence of mind communicated itself to those she addressed, and they remained in their places. An ample supply of water and other resources were in readiness, with active hands that knew how to employ them. Some daring carpenters, at the hazard of life and limb, detached the flaming border from the mass above, and in a few moments the stage was in a deluge, strewed with the wrecks of scenery that had been destroyed. Mr. C. Kean then announced the impossibility of concluding the play, and requested the indulgence of the audience for the inevitable omission. They dispersed quietly, and, as we may suppose, deeply impressed with the general escape from an awful danger. But strange elements are mixed together in the composition of human feelings, under any circumstances. For several days after, letters were received by the management from parties requiring either a return of their money, or admission for another night, because a small part of the performance had been curtailed by the fire. These sticklers for the full value received, remind us of the respectable old lady in Colman's comic tale; who, when her son fell from the gallery to the pit, and broke lis neck on the spot, as soon as she recovered from the shock, said to the money-taker, -

"But I must have the shilling back you know, As Moses did not see the show."

Mrs. C. Kean's calm and courageous exertions during this accident wcre the theme of just and universal encomiums. But amongst the most gratifying tokens of 
acknowledgment she received, was one proceeding from a humble source, but not the less acceptable on that account. Some of the working men of the theatre requested her acceptance of a handsomely-emblazoned testimonial, framed and glazed, bearing the following inscription :-

\author{
" PRESENTED TO \\ MRS. CHARLES KEAN, \\ BY THE
}

OPERATIVES OF THE PROPERTY DEPARTYENT,

OF THE

ROYAL PRINCESS'S THEATRE,

AS $\triangle$ MARK OF THEIR ESTEEM AND ADMIRATION

FOR HER HEROIC CONDUCT,

ON THE NIGHT OF THE FIRE AT THE ABOTE THEATRE,

MAY 13TH, 1557."

Such unpretending gifts are less costly and ostentatious than diamond necklaces and bracelets, but they come from the heart, and are equally, if not more valuable, when transmitted as heir-looms; for, as Shakespeare truly says,-

"Never anything can be amiss,

When simpleness and duty tender it."

The public have long been accustomed to admire in Mrs. C. Kean the accomplished artist, whose rare endowments shed lustre on her profession, while they supply an encouraging example to her successors. But the public cannot step behind the more interesting scenes of her private life, and obtain a full knowledge of the wonderful activity and energy of her character. Perhaps the voice of personal friendship may be permitted here to offer its tributary homage, founded on long experience and observation. While ansiously aud affectionately 
seconding her husband throughout his arduous career of management, her immediate province has been the superintendence of the wardrobe. An idea of the heavy responsibility of this office may be formed from the fact, that in many of the great Shakesperean plays, no less than fine hundred dresses have had to be designed and arranged; enough of itself to occupy the mind, and distract it from the study of such fine intellectual creations as Constance, Hermione, Queen Katharine, and Lady Macbeth. At all times and seasons, in sickness or in health, whether the tide of human affairs runs placidly or becomes troubled, there is in Mrs. C. Kean an imperturbable self-command and equality of temperament, a warmth of active benevolence, a generous sympathy with, and consideration for the wants and failings of others, which excite the esteem and wonder of all who are acquainted with her. By what economy of time she is enabled to superintend three distinct households, independent of her professional duties, no stranger could possibly be made to understand. In addition to her own establishment, she has her aged mother and elder sister, helpless themselves, and entirely dependent on her care; and another widowed sister with an overwhelming family, who look to her sustaining counsel as their earthly guide and beacon. These are complicated duties, and nobly they have been discharged.

Another of Mr. J. M. Morton's agreeable trifles, always of French origin, entitled, "An Englishman's House is his Castle," appeared on the 11th; and on Wednesday, July the 1st, "Richard the Second," after the eighty-fifth night, was withdrawn for a time, to make way for "The Tempest."

Shakespeare's "Tempest," as all the world knows, is a work exclusively of imagination; beautiful in thought, 
and original in execution. Coupled with "A Midsummer Night's Dream," the two form, beyond all question, the richest and most delightful creations of fancy, which human faculty has ever embodied in the poctical or dramatic form. Supernatural and imaginative in the highest degree, they are as varied in character, as the elements of the inexhaustible genius which never exhibited the poverty of repeating itself. The fairy wands of Oberon and Titania have nothing in common with the necromantic staff of Prospero. The familiar agents, Ariel and Puck, the delicate and the mischierous, are as unlike each other as the masters to whom they are subservient. In Mr. C. Kean's treatment of these exquisite subjects, we trace again the careful study and unerring judgment which have on so many previous occasions won for him the reputation of Shakespeare's truest interpreter. Ariel, in particular, he has invested with an air of originality, the more surprising as the play has been elaborately "got up" under many successive managements. There have been Ariels in profusion, who could act and sing beyond the reach of critical censure, but they were full-grown voluptriouslooking females : no one could beguile himself into the delusion that they were anything less material or substantial. Mr. C. Kean has given us, and for the first time, the dainty spirit, the etherial essence that could be compressed within a rifted pine, that appears formed to revel on a bat's back, to couch in a cowslip's bell, to tread the ooze of the salt deep, and to run upon the sharp edge of the wind.

Volumes have been written by heavy, matter-of-fact commentators, who delight in multiplying clouds and darkness, but seldom irradiate an obscurity, - to prove that Shakespeare founded the "Tempest" on real facts and places, that he drew from some known story or 
published incident; that he is, in this instance, a mere compiler of events, or an ingenious adapter and enlarger of the thoughts of others. There is some confused story that the poet Collins had read the subject in a novel ; but he failed to recollect the name, nor could any one else identify the work from his account of it. One elaborate pundit has endeavoured to show in a rambling essay, that Lampedusa was unquestionably the island of Prospero, because it $i s$, or was, uninhabited, and lies somewhere in the latitude and longitude within which it is possible a ship might be wrecked on a voyage from Tunis to Naples. The claim set up for Bermuda is more ridiculously out of the question, and plainly disproved by the text. Ariel was once ealled up at midnight by Prospero, "to fetch dew from the still vexed Bermoothes." The magician would have had no occasion to send his messenger so many thousand leagues across the Mediterranean and the Atlantic for the precious exhalation, if his own island were the identical place in which he could have supplied himself by merely stepping to the entrance of his cell.

Malone and Chalmers each wrote and printed, for private distribution, tracts on the incidents from which the "Tempest" is derived. As literary rarities, their pamphlets have sold respectively for two and three 'guineas each ; they contain ingenious conjectures, and help to prove what Shakespeare did not intend. We confess to no feelings in common with the dull, mathematical precision which seeks to extinguish the brightest rays of poetical fancy, and to measure an illimitable mind by the ordinary physical standard.

The play taken as a whole, is indeed,-

"A most majestic union, And harmonious charmingly." 
Let due honour be rendered to Mr. C. Kean, for rescuing Shakespeare from all attempts to localize the scene of action. IIe says truly, "The enchanted island governed by the mind of Prospero, released from its association with the Bermudas, remains an imaginary kingdom, the scene of affecting and mysterious incidents, over which Ariel presides as the image of air, in spiritual contrast to the grosser Caliban, who embodies the earthly element."

Shakespeare has fixed no distinct time when the action of the "Tempest" is supposed to pass, either directly, or by inference. In the present revival, the thirteenth century was selected, as affording the opportunity of introducing a style of costume at once elegant and picturesque.

In earlier times, the "Tempest," like many of Shakespeare's acknowledged master-pieces, suffered terribly from ruthless mutilations. Sir W. Davenant, Dryden, and Shadwell, successively transformed it into a comedy and an opera; in which they were followed by Garrick, the elder Sheridan, and John Kemble, who retained the injudiciously introduced characters of Dorinda and Hypolito; thus completely destroying the idea of the author, and the key-note of feeling to the whole play, - the utter desolation of Prospero, with Miranda as his only consolation and companion. The last manager, too, with all his admitted classical taste, transplanted the opening incident of the storm and shipwreck to the second act, where its position is incongruous. He also removed the celebrated speech in allusion to the introduced masque in the fourth act, beginning with "These our actors, as I foretold you, were all spirits," to the end of the play, and in cxclusion of the original epilogue. Mr. Kean, following out the system he has invariably acted on in these glorious revivals, presents the text of Shakespeare inviolate, omitting merely an occasional 
passage, or compressing a subordinate scene, with manifest advantage to the action of the piece. That the last opinion is correct, is evidenced by the approbation and attendance of eighty-seven successive audiences.

One of the most strikingly original conceptions in the new version of the "Tempest," was the entire execution of the music (with the exception of the duet in the masque) by an invisible choir, led by Miss Poole, whose mellow voice sounded with the rich, full clearness of a bell in the midst of, and above, the accompanying melody. Much of this music has hitherto been executed by Ariel, in presence of the audience, rendering too material and terrestrial that airy essence, through whose unseen agency, and by the delegated authority of Prospero, the train of magical wonders is produced throughout the play. Ariel formerly walked on and off the stage after the conventional mode of entrance and exit, moving with the substantial attributes of mortality; and when dismissed on an important errand, instead of "drinking the air" in rapid obedience, came deliberately forward, while the orchestra struck up a symphony, and sang to the musicians instead of to Prospero, an interpolated aria, beginning with, "Oh bid your faithful Ariel fly," with one cye fixed on the pit, and the other carefully watching the flourish of the conductor's bâton. Now, we were really presented with a "delicate spirit," at one moment descending in a ball of fire; at another, rising gently from a tuft of flowers; again, sailing on the smooth waters on the back of a dolphin; then, gliding noiselessly over the sands, as a water-nymph; and ever and anon, perched on the summit of a rock, riding on, a bat, or cleaving mid-air with the velocity of lightning. The powers of modern stage mechanism are almost as marvellous as the gift ascribed to the magic wand and bonk of Prospero. 
The play opens, as Shakespeare has described, with a ship in a tempest, struggling against the combined fury of winds and waves, and ultimately seeming to founder with all on board. How such an effect could be produced, within such a confined space, appeared to baffle the comprehension of the audience. As the mist of the storm disperses, the sun rises slowly on the magic island, the sea subsides, the waters recede from the "yellow sands," and Prospero is discovered with Miranda, standing on the point of a rock, superintending the effect of his art. He descends, and relates the events of his early life, his deposition and banishment through the treachery of his brother. Ariel and Caliban are summoned in succession. Ferdinand enters, and at the first sight, he and Miranda "change eyes."

In the second act, we have a romantic view of the interior of the island, where the King of Naples, with his attendant lords, has landed, and is hopelessly seeking for his lost son.

A great triumph of scenic exhibition is reserred for the third act. A long perspective of desolation gradually changes from barrenness to tropical luxuriance; trees rise from the earth, fountains and waterfalls gush from the rocks; while naiads, wood-nymphs, and satyrs enter, bearing fruit and flowers, with which they form a table, and having invited the King ard his company to partake, suddenly disappear. These classic denizens of the woods are substitutcd for the " strange shapes" without any specified identity, hitherto represented by ludicrous and unmeaning monsters, with devils' heads and pitchforks, as being not only more poctical in themselves, but also more in accordance with the figure of the Ilarpy which rises in the midst of them. The novelty and elegance of the concluding dance cxcited universal admiration. 
The fourth act is chiefly occupied with the gorgeous masque of Juno, Ceres, Iris, and their attendant deities; and richly here does Prospero exhibit the "vanity of his art," always assisted by his obedient familiar, Ariel. At the conclusion, Caliban and his sottish associates, in the plot to murder Prospero, are hunted and tortured by a legion of goblins, copied from furies depicted on Etruscan vases.

In the fifth act, all the characters are brought together by the eontrolling power of Prospero, in front of his cell. Mutual recognition takes place. The stately magician forgives the wrongs he has suffered from his false brother, bestows his daughter in marriage on Ferdinard, and prepares to re-ascend his ducal throne; having renouneed for ever the supernatural power he had aequired, breaking his staff and drowning his book. Night enshrouds the scene. The released spirits take their flight from the island, through the air ; morning breaks, and shows the royal vessel floating gently, and in perfect trim, on the unruffled waters. Prospero, standing on the deck, delivers the epilogue. The ship gradually sails off, the island recedes from sight, Ariel alone occupies the seene, suspended in the air, anxiously watehing the departure of his late master, while a distant ehorus of spirits dies softly away as the curtain falls. Beautifully contrasted is this last scene with the terror and despair of the opening shipwreck. The aetion and situation, the glass-like, motionless tranquillity of the unruffled waters, the glow of atmosphere, and the accompanying sentiment, more easily felt than described, reminded us of Moore's gently flowing lines, written when sailing within the tropics:-

" The sea is like a silvery lake, And o'er its calm the vessel glides, Gently, as if it fear'd to wake The slumber of the silent tides." 
Mr. C. Kean was dignified and impressive as Prospero. The character has always been undertaken by the leading tragedian of the day, although it affords no scope for the powers of a first-rate actor. There is neither passion nor variety. All that is required for an adequate representation is sustained solemnity of deportment, with graceful elocution, and here and there an impulse of natural feeling. But the potent necromancer so completely rules the action of the play, and every agent employed is so thoroughly subservient to his will, that the audience nerer lose sight of his paramount importance. Like Mephistopheles, he is felt even when he is not present, and is always expected to appear when wanted, as the deus ex machina, to solve every difficulty, and to settle every doubt.

The true spirit of Ariel, as now so artistically remodelled, was caught up by Mišs Kate Terry with intuitive quiekness. Miss Leelereq and Miss Bufton were delightfully coupled as Miranda and Ferdinand. Mr. Ryder had evidently studied Caliban with a perfect understanding of the author's intention. His execution of this difficult part (difficult, because so easily overdone), was one of the best of his many judicious assumptions. Harley, as Trinculo, and F. Mattliews, as Stephano, brought out the eomic relief of the play in excellent bearing. The scenery, dances, eostumes, music, and mechanical effects, in every department, excited universal admiration.

The public, in general, are scarcely reflective enough to estimate at their full value the amount of labour, time, and intellectual exertion, to say nothing of the expenditure of capital, by which such a revival as the "Tempest" is carried out to the perfection that appears so easy and natural when offered to public consideration. Mr. C. Kean, by a long series of these costly and elevated 
experiments, has shown of what the stage is capable, when viewed in the light of a national instructor. $\mathrm{He}$ has added another, and a most influential medium to the many sources of educational improvement which at present engross the consideration of the best, the wisest, and the most exalted in the land.

It has often been said by enthusiasts who mourned over the degraded position of the stage, real or exaggerated, and who felt, or affected to feel, the misapplication of its noblest attributes, that the theatre might be rendered a valuable school, as well as a fascinating temple of recreation. The question has now ceased to be one of retarded or doubtful solution. It has been met by Mr. C. Kean with an unequivocal result. What has been suggested as possible, he has triumphantly accomplished. He has, reformed, nay, he has even regenerated, the national drama of the country. He has revived a pure taste, which seemed to be verging towards extinction; and in an age when orators and philanthropists of every class are clamouring for intellectual progress, he has brought in, to further this great object, the most powerful and attractive auxiliary that refined intellect can supply. Museums are but dumb instructors. Galleries of sculpture and painting, with their catalogued treasures, are cold and formal. Lectures on philosophy, metaphysics, and mechanical science, are, of necessity, tinged with technical pedantries. Logic never charms, while it often wearies more than it convinces. The principle of mingling the utile cum dulci, of amusing while you teach, is as applicable to human nature now, as it was in the days of Horace. The child is a type of the man, and a sick child refuses the medicine which brings health when presented in its natural bitterness, but swallows it voraciously when sweetened with honey. The mass of mankind is more 
likely to profit by instruetion agreeably insinuated than harshly commanded. The theatre is a gentle monitor, and as such, acceptable to the tastes of a great majority; appealing to the reason, it is true, through the pleasant, though perhaps hazirdous medium of the senses, and therefore open to objection, as easily pervertible to abuse. But the lesson is not the less efficacious, if judiciously administered, as the senses constitute the most powerful alembic through which knowledge can be instilled into the mind. The multitudes who have no time or taste for reading, whose faculties are not moulded for profound study, are readily impressed through the eyes and ears with those important truths, whieh, while they expand the understanding, soften and improve the heart. The harmonious poetry of Shakespeare presents nothing incompatible with the higher sources whence our soundest moral doctrines are derived. Persuasion often wins more than authority, and in this sense (we speak it reverently), the stage may avail when graver teaching fails. The quaint old poet, Herbert, took a correct view of man as he is, when he wrote :-

"A verse may find him who a sermon flies, And turn delight into a sacrifice."

Mr. C. Kean closed his seventh season on the 21st of August, 1857. During the twelve months (wanting but ten days) of its duration, not more than twelve picees were performed, of which three only, including the Pantomime, were new. Out of the two hundred and ninety acting nights, no less than two hundred and forty-two were devotel to Shakespeare. This fact speaks more conclusively in favour of Mr. Kean's system, and furnishes a more unanswerable reply to its opponents, than a folio of laboured pancgyric.

VOL. II. 


\section{CHAPTER XI.}

VACATION OF SEVEN WEEKS-MR. AND MRS. KEAN VISIT VENICE-THE THEATRE OPENS ON THE 12TH OF OCTOBER, NEWLY DECORATED-THE TEMPEST RESUMED-RUNS ALTOGETHER FOR EIGHTY-SEVEN NIGHTSREPRODUCTION OF RICHARD THE SECOND-PANTOMIME OF THE WHITE CAT-DEATH OF LADY BOOTHBY, FORMERLY MRS. NISBETT-MR. KEAN ELECTED A FELLOW OF THE SOCIETY OF ANTIQUARIES-FESTIVAL PERFORMANCES AT THE OPERA HOUSE ON OCCASION OF THE PRINCESS ROYAI'S MARRIAGE-ABSENCE OF MR. AND MRS. C. KEAN-OPINIONS EXPRESSED IN THE PAPERS-MACBETH AT THE OPERA HOUSE-HAMLET AT THE PRINCESS'S ON THE SAME EVENING-DEMONSTRATION IN THE PRINCESS' THEATRE ON THE 19TH OF JANUART-STATEMENT OF FACTS.

THE Princess's Theatre remained closed for seven weeks, during which time it was entirely re-painted and decorated in a light and tasteful style.

During the recess, Mr. and Mrs. C. Kean made a short trip to the continent, passing by Paris and Lausanne, and across the Alps to Milan, Verona, and Venice. Mr. C. Kean had long desired to see the "Queen of the Adriatic," and as the "Merchant of Venice" was intended for a leading feature in the forthcoming season, he determined to verify the authorities by personal examination.

On the 12th of October, 1857 , the theatre re-opened, and the "Tempest" was resumed. The dramatic horizon looked cloudy at this juncture. The American defalcations had produced a commercial panic, the extent and influence of which was undefined. Many failures were gazetted, and more anticipated. From day to day there were announcements of actual, and reports 
of expected bankruptcy, which checked the ordinary current of society, and drew away attention from public amusements. Under similar contingencies theatres are always amongst the greatest sufferers. We speak of England exclusively, for in France the general feeling takes an opposite turn. During the horrors of the Revolution, under the reign of terror, when the guillotine knocked at every door, and no one could tell how soon his own turn would succeed that of his neighbour, the theatres were crowded nightly. In 1814, and again in 1815, after Waterloo, when the cannon of the allies, frowning from the heights of Belleville and Montmartre threatened Paris with destruction, the loungers of the Boulevards sat on their accustomed seats in constitutional carelessness, and repaired to the Odéon, the Gaieté, or the Varictés at the usual hour, as if things were progressing in their customary routine.

After a run of eighty-seven nights, the "Tempest" was finally withdrawn, and "Richard the Second" again assumed its place in the bills. Amongst the characters which have won for Mr. C. Kean his acknowledged position as the first tragedian of the age, many sound critics were disposed to assign the foremost place to his Richard the Second. They looked upon it as an original effort to be paralleled with Louis the Eleventh. None of his most eminent predecessors, as in many other instances, had associated their names with the part. It suggested no comparisons. Betterton and Booth, Quin, Garrick, and John Kemble, had passed it by. Edmund Kean, it is true, elicited from it some brilliant points, but although the performance greatly enhanced his individual reputation for the moment, it retained no permanent place on his acting list. It remained for his son to identify himself with the deposed Plantagenet. A play, never before 
attractive, which on its first production commands eighty-five repetitions, and within a few months is again resumed for twenty-seven more, must be assisted with some controlling element of success, which no beauty of language, no perfection of decorative accompaniment, no amount of archæological accuracy could of themselves supply. This great element must be sought for in the power of acting; that rarely bestowed endowment by which alone the purpose of the poet can be adequately reflected, and through which channel only, the by-gone ages of the world are called into new existence, placed before the sight, and presented to the mind of the spectator and auditor, as in a living panorama. The scenes of memorable deeds, the actions and attributes of remarkable men, are thus stamped on our memories and rendered familiar to our perceptions with an enduring strength, which no other medium of information, no silent study in the closet, no consumption of the midnight lamp, no recorded description could possibly impart.

At the last session of the Socicty of Antiquaries, during the summer of 1857 , on the memorable 18th of June, Mr. Kean was elected a fellow of that erudite body, and on the 19th of November following, took his seat in regular form as an admitted member. The compliment was as flattering, as it was well earned and judiciously bestowed.

On the 16th of November, a new farce was brought forward at the Princess's, cleverly adapted from the French, by Mr. John Oxenford, entitled "A Case of Conscience." It ran for many nights up to the production of the pantomime, and may be ranked amongst the most agreeablc of the light pieces usually selected at the Princess's Theatre to play in the Shakespearean revivals. The pantomime, founded on a well-known 
story, was entitled "Harlequin and the White Cat; or, the Princess Blancheflower and her Three Godmothers." This branch of the dramatic art appears destined never to lose its Christmas attraction, although it has been often said that the true genius of pantomime has been for some time effete, and died with Grimaldi. But there is as much immortality in the Clown as in Punch. It is quite certain that Grimaldi is no longer here to enliven us with his fathomless inexpressibles that held every thing in the world, his inimitable thieveries, his jokes, his songs, and his dialogue; but another style of humour has succeeded with another generation. The laugh is as unremitting as ever, although the prompting excitement is not exactly the same. There is somcthing in the natural constitution of man in the abstract, that attaches him to pantomime. It argues ill for the moral temperament of any one who cannot enjoy this glorious mummery. We should hesitate to select such an unhappy exception for a travelling companion or a next door neighbour. If Heraclitus were to return to earth and secure a stall on any given night during the holidays, we doubt if he would ever again lapse into his constitutional melancholy. If Cato, the censor, could stalk in after lim, with scorn and anger at his heart, and a decree for the abolition of theatres in his pocket, we are prepared to offer the long odds that he would be beaten by the epidemic mirth with which his eyes and ears would be assailed. At the first peal he would suspend his purpose, at the second, his grim plilosophy would relax into a smile, and at the third, he would trample his decree under foot. If any of our readers labour under low spirits without knowing why,-that depressing malady of the mind which the learned denominate hypochondria,-we earnestly recommend them to try a course of pantomime, which will prove a 
more certain, as well as a much more palatable mode of cure than the whole series of scientific remedies, with hard appellations, which supplant each other as quickly as the fashions alter, and not unfrequently before we are able to spell their names.

On the 18th of January, 1858, died Lady Boothby, better known as Mrs. Nisbett, one of the most fascinating actresses of modern times. Her joyous, resonant laugh, will never be forgotten by those who remember her as Lady Gay Spanker, ("London Assurance,") or as Constance, in the "Love Chase." She was the eldest daughter of the late Lieutenant Frederick Hayes Macnamara, 52nd Foot, and of his wife, Jane Elizabeth Williams. At the time of her death she was in her forty-sixth year, having been born on the 1st of April, 1812. She evinced theatrical talent as a child, and in consequence of family misfortunes adoptcd the stage as a profession before she had completed fourteen. She appeared at Drury Lane when about seventeen years of age, and soon took rank in the first class of comedy, a position she maintained through her life. In January, 1831, when still under twenty, she married Captain John Alexander Nisbett, of the Life Guards; who, within a few months, was killed from the effects of an accident received while trying a vicious and untrained horse. On the death of her husband, Mrs. Nisbett felt herself under the necessity of returning to the stage; and, having for several seasons delighted the London public by her brilliant acting, she was again led to the altar by Sir William Boothby, Bart., of Ashbourne Hall. In about three years Sir William died, and she found herself a second time a widow without adequate provision, and once more compelled to resume her theatrical profession. But failing health soon demanded her final retirement from public life. Her 
last days were spent in domestic retirement with her mother and eldest brother, whose almost sudden deaths within a short period of each other, added to the loss of a dearly beloved sister, so wrought upon her exhausted frame that she was attacked with the illness which, in two days, terminated her existence.

On the 25th of January, 1858, the Princess Royal of England was united to Prince Frederick William of Prussia, heir presumptive to the throne of Frederick the Great; representative also of a staunch Protestant family, the ancient allies of England, and previously connected with the royal line of Hanover by the marriage of the late Duke of York with the eldest daughter of King Frederick William the Second. Great care had been taken to bring the young couple into previous acquaintanceship, and to give them opportunities of becoming mutually attached; a guarantee for future happiness too slightly estimated in royal alliances. In these points the marriage was highly acceptable to the feelings of the English people. Prussia, it is true, was looked upon suspiciously in a political sense. She had played a doubtful part during the Russian war; had carried the produce of our enemies to and fro in the ports of the Baltic to the detriment of British trade, and in evasion of existing treaties; but this was looked upon as arising more from the personal bias of the King than from the wishes of his nation, who were supposed to side warmly with us in thcir hearts. Prussia was awkwardly placed, with an open fronticr, almost in the jaws of her gigantic neighbour, and in danger of being swallowed up, in case of a rupture, before distant allies could arrive in time for rescue. Kingdoms of more internal strength, and less accessible to foreign attack, had set the example of a temporising policy with infinitely less excuse. England has so com- 
promised herself more than once when misgoverned by men who, with little reputation of their own to lose, bestowed cven less thought on the honour of their country.

On the occasion of this auspicious marriage, many royal foreigners were invited as the guests of our gracious Queen. Amongst other festivities, a series of four dramatic performances under the immediate patronage of her Majesty, and directed by Mr. Mitchell, of Bond Street, was announced to take place at the Opera House, in the Haymarket, selected for the purpose from its size and superior accommodation. These performances were to consist of a tragedy, a comedy, and farce, an English and an Italian opera; the two leading objects being to gratify the public with an unusual display of royalty congregated in honour of a national event, and to exhibit before that august assemblage the most perfect specimens of English dramatic art that living talent could supply. Nothing could be better in idea than this plan, which nevertheless, like many others equally well laid, was marred in execution by clumsy diplomacy that might have been easily rectified. Both objects failed. The absence of several firstrate names, particularly those of Mr. and Mrs. C. Kean, with a total want of skilful organization in the disposable strength, reduced a portion of the performances to a scale of painful mediocrity, that must have sadly disappointed the strangers who were expected to wonder and admire; while the general public were ostracised by the fabulons prices of admission, which the speculators deemed it convenient and were permitted to exact. They were, in fact, the only parties who had reason to be satisfied with the result.* The actors

* As much as eight, ten, and even twelve thousand pounds has been named as their net profit; but this must be taken as mere report, resting upon no evidence beyond probable conjecture. 
wasted their efforts on an audience drawn together by the show in front, and not by the professional talent, which they could see at any time, to more advantage and with undivided attention, in the theatres from whence they were drafted.

As soon as it became known that "Macbeth" was to take the lead in these festival performances, and that the principal characters would not be sustained by Mr. and Mrs. C. Kean, people began naturally to inquire the cause of this omission. It seemed unaccountable that the first actor and actress of the day, and the selected director of her Majesty's private theatricals at Windsor, should have no part in an arrangement apparently emanating from royal desire. Much disquisition took place on the subject, and many paragraphs appeared in the journals, conveying something like a general impression, coupled with surprise, that Mr. C. Kean, under the avowed circumstances, must either have given cause of offence in some quarter, or had not been treated, for some reason or other, with the courtesy to which he was entitled. A few extracts, takicn promiscuonsly from the papers, will show that opinion, howerer differently expressed, and based on such imperfect facts as had transpired, verged always towards the same point.

The Morning Herald wrote thus (18th of January) :-

"Much conversation has arisen, and many conflicting statements have gone abroad, on the subject of this forthcoming dramatic festival, as it has been designated. Amongst the points which have been most cliscussed in connexion with the matter, is the absence from the announced programme of Mr. C. Kean and his company. This omission must appear the more surprising to the public from the fact, that Mr. C. Kean has for 
many years conducted, with marked approbation, her Majesty's private plays at Windsor. We cannot pretend to penetrate completely the mystery in which the transaction is involved; but we have been informed that Mr. Kean, in the course of the brief negotiations which took place upon the point, held the opinion that all the leading theatres might be thrown open in celebration of an event which may be regarded as a subject of national congratulation; and that he expressed his readiness to carry out such an arrangement in his own establishment. Whatever may be the view we entertain of the misunderstanding which has thus arisen, we cannot help regretting that from this theatrical commemoration of a most interesting ceremony, the greatest of our tragedians should be excluded."

The following article appeared in the Morning Chronicle (January 15):-

"Many rumours are current with reference to the dramatic representations which are to take place at her Majesty's Theatre, in honour of the Princess Royal's marriage; and the plan, as at present announced, has not been met by any very warm sympathy on the part of the public.

"Why could not the projected entertainments have taken place alternately at the regular theatres? The different plays would have been better acted on their own ground; the public expectation would have been more amply gratified; and the remuneration would have flowed into more legitimate channels. 'Macbeth' is to commence the series; but, in the absence of our leading performers, Mr. and Mrs. C. Kean, it can scarcely convey to her Majesty's foreign guests a correct impression of our national stage. Mr. Kean, as we understand, has declined to assist in a private com- 
mercial speculation. In the same manner, an English opera is to constitute another night's performance, without the presence of our first tenor, Mr. Sims Reeves."

In the Examiner (16th January, 1858) we find this notice :-

"The arrangements, as they have been announced, with reference to the four performances at the Opera House, under her Majesty's patronage, on the occasion of the Princess Royal's marriage, have given rise to much conversation, and, we are sorry to add, not a little discontent. The professed ebject is the gratification of the public, who will virtually, however, be shut out, owing to the enormous scale of the prices of admission, and the exclusive construction of the theatre selected. The affair is avowedly a commercial speculation on the part of the undertaker, entered into at his own risk; and a great portion of the boxes and stalls being farmed out to the acknowledged theatrical agents, they will, naturally enough, exact prices rising in proportion to the extent and eagerness of the demand; while the name and presence of the Queen, with those of her royal and illustrious guests, will, of course, be sedulously paraded and turned to the best pecuniary account, like any other novelties or attractions of the hour. All this, indeed, is taking place already.

"A correspondent of the Globe of Thursday evening complains loudly of the extortions practised under the sanction of her Majesty's name, with reference to the entertainments in question. The Daily News of Friday publishes another letter, protesting against the same proceedings in still stronger terms, and detailing facts within the writer's personal knowledge.

"Surely there is something improper and undignificd 
in all this, which it would have been both good taste and good sense to avoid. It is, also, naturally asked why a gentleman, in no way connected with the English stage, should have been selected to direct these performances in preference to Mr. Charles Kean, so long the conductor of her Majesty's private plays at Windsor, not to speak of his professional eminence and merited popularity. The name of an actor so distinguished and accomplished as Mr. Kean does not even appear in the programme. If, as we have heard it stated, Mr. Kean objected to co-operate with Mr. Mitchell, on the ground that the plan was, in fact, a private undertaking, injurious and opposed to the interests of his own and the other regular theatres, and ill calculated to afford any substantial satisfaction to the public, we must say the objection appears to us to have been perfectly just. A little more tact in the management of these festivities, might certainly have been displayed with advantage. The plan of alternate visits to the principal theatres would have produced more general satisfaction; or each manager might have been allowed to superintend his own play, with a fair share in the profit, if any, of the night's performance."

The following appeared in the Court Circular of the 16th of January :-

"The forthcoming 'Dramatic Festival,' in celebration of the Princess Royal's marriage, does not appear to increase in popular favour; and it is generally felt that no opportunity will be afforded to the people of participating in what, on the surface, appears intended for their gratification. Although the royal party will be present at four public theatrical performances, these are rendered so exclusive, by an enormous scale of 
prices, that only the most opulent of her Majesty's subjects will be able to behold the august assemblage.

"Neither can any benefit accrue to the leyitimate London managers from this mode of appropriating the royal patronage. An opposing attraction, and a very powerful one, is raised up against their own theatres, in the heart of the Christmas season, and nothing whatever is vouchsafed to them to compensate for the unexpected injury.

"To this view of the affair we are, doubtless, to attribute the fact that Mr. Charles Kean is not included in the list of those who contribute to the 'festival entertainment.' Nothing beyond surmise has yet transpired with regard to the omission of a name that, alone, would have made the performances representative, inter alia, of English tragedy as it now exists in the metropolis. The cause of Mr. C. Kean's absence will certainly be demanded by the public. A Shakespearean drama played before an assembly of crowned heads, without the assistance of the great Shakespearean actor of the age, is too strange a fact not to elicit anxious inquiry amongst all classes of this independent and intellectual capital."

The "festival performance" of "Macbeth" came off on Tuesday, the 19th of January. The day after, the following notice appeared in the Times :-

"It is not nsual, in recording public festivals, or other exhibitions, to note down what does not take place; but, nevertheless, an omission may be so cxceedingly important as to render the blank it leaves quite as conspicuous as any object presented to the eye. The Roman procession immortalized by Tacitus, in which the busts that were not carried outshone a host 
of sculptured Manlii and Quinctii, is familiar to the merest dabbler in classical literature; and those who have not smattered so far, may, if they please, illustrate the omission to which we here immediately allude, by imagining a Lord Mayor's show, with the Lord Mayor's carriage empty. Of course, we refer to the absence of Mr. Charles Kean's name from the list of the artists engaged last night as representatives of English tragedy. By histrionic genius, matured of late years to its highest degree of perfection, and by a splendid style of stage management that has made the production of each succeeding season eclipse its predecessor, Mr. Charles Kean has made the Princess's Theatre the acknowledged home of the Shakespearean drama. The days of the patents have passed away, but the privilege of holding an exclusive rank for the performance of the tragic drama has now belonged for several years to the Princess's Theatre; and to the exertions of Mr. Charles Kean, in his twofold capacity, is this high position to be solely attributed. No one could, indeed, ignore the unquestionable merits of $\mathrm{Mr}$. Phelps in raising the character of Sadler's Wells, and implanting a veneration for Shakespeare in a public previously accustomed to lower forms of the drama. But, setting all other consideration aside, it is still impossible to regard the Pentonville district as the focus of the metropolitan drama, or to accept the presence of Mr. Phelps as a reason for the absence of Mr. Charles Kean. "Why is the manager of the Princess's Theatre and of the Windsor theatricals not here?' is a question that must have forced itself last night upon every person who had not mixed in circles where theatrical politics form a staple of conversation. Italian opera will be represented by Mr. Lumley's company, with Signor Giuglini and Mademoiselle Piccolomini, both (for the first time) in 
"La Somnambula;" English opera will be represented by the Pyne-Harrison company, engaged on the last new work by Mr. Balfe; the comic drama will be represented by contingents from various theatres; but tragedy is performed without the artist who, above all, is considered its representative. Here is, indeed, a case of the omitted Brutus-of the black cloth of Faliero.

"A case so remarkable needs some explanation, and we believe the facts are something like these, though we by no means warrant them proof against correction. Mr. Charles Kean was not passed over in the selection of actors to play at the 'festival performances,' but, on the coutrary, was, in the first instance, requested by Mr. Mitchell, who has the management of the solemnities, to undertake the character of Macbeth. The request, it should be distinctly understood, was made by Mr. Mitchell in his own capacity, as a speculator in the advantages to be derived from a theatre on the occasion of a royal risit; and, therefore, Mr. Charles Kean was not bound to regard it as a demand or invitation from the Court. Exereising the right of choice which, under these circumstanees, belonged to him, he refused to take any part in the 'festival performances.' Probably he considered that, after many years' good service as superintendent of the Windsor theatrieals, the management of a theatrical entertainment associated with a royal marriage might have been confirled to his well-tried energies; probably, too, he thought that 'Nacbeth' produced under other direction than his own might not impress the foreign visitors of this country with a correct notion as to the manner in which Shakespeare's plays are put upon the stage for the first-class audiences of this country. At all events, this much is certain, that he acted on the broad prin- 
ciple, that one manager is not bound, by right or by courtesy, to act for the benefit of another manager; and this much, also, is certain, that his refusal to play is highly commended by many adepts in theatrical politics. In an article merely intended to record the events of an evening, it is not our intention to plunge into the depths of a controversy. We merely wish to explain, in as few terms as possible, the alleged reason of Mr. Kean's non-participation in the 'festival performances.'

"However, the attractions of the stage were but of secondary importance last night. The royal party did not arrive till deep in the second act of 'Macbeth,' just when Mr. Phelps had begun the famous dagger soliloquy. Now, the royal party was what the audience expressly came to see, and the eyes constantly directed towards the large empty box denoted an anxiety that did not in the least refer to the fate of Duncan. On the entrance of Her Majesty everybody, of course, arose, and then the scrutiny of the brilliant assemblage occupied all who could get a sight of it. So, somehow or other, the tragedy reached its conclusion, not closely watched in its tardy course, and leaving a strong impression that spoken dramas do not greatly move Operatic audiences. Music is evidently required to arouse the sympathies in Her Majesty's Theatre, for even the compositions ascribed to Lock, and so often scorned, proved welcome last night. How, in the presence of that frigid public, must Mr. Phelps have longed for the hearty Shakespeareans of his own district! How, if the report of the frigidity reaehed the ears of Mr. Charles Kean, must he have rejoiced to think low well he was out of the affair! It is no joke to play tragedy before a blasé public, whose whole mind is absorbed by a royal box, and who dislike to find their 
meditations interrupted by a ruffle of applause. Mr. Phelps manfully sustained his energies to the end, and well earned the plaudits that, on the fall of the curtain, proceeded from the dramatically-disposed portion of the audience. Miss Helen Faucit, also, was called for at the close, and though she did not immediatcly make her appearance, she stood prominently amongst the singers during the performance of 'God save the Queen.'

"The singing of this anthem was the real feature of the evening, and the spectacle presented when the whole audience rose, including the occupants of the royal box, was such as could not easily be found beyond the precinets of our magnificent Opera House. For presenting a royal party to the public, and for demonstrating the feeling of that public to Royalty, there is no place like her Majesty's Theatre. At the first note of the national anthem all frigidity had vanished, and the acclamations of an audience that completely filled the house were heard on every side."

On the evening of the performanee of "Macbeth" at the Opera House, Mr. Kean appeared as Hamlet at his own theatre. 'The feeling prevalent in the public mind that he ought at that moment to be engaged elsewhere, and that he had received a slight in the omission, led to a special demonstration of respect on this particular occasion. The house was crammed to suffocation in every part soon after the opening of the doors, and hundreds were turned away, unable to obtain cutrance. The stalls and boxes were filled by a company more than usually brilliant; the pit and gallery contained hosts of enthusiastic Shakcspearcans, asscmbled to mark their high estimate of his living representative's claims and position, as actor and manager.

On his eutry, Mr. Kean was received with a perfect VOL. II. 
storm of approbation. The stalls rose in a body ; their example was followed by boxes, pit, and gallery. Cheers upon eheers resounded through the house, and some minutes elapsed before the business of the scene was thought of, or the play could resume its course. Doubtless many of his own personal friends were present; but they alone could not have produced the furore which manifested itself. It was a genuine and hearty expression of public feeling, on account of what was evidently considered a public wrong.

Mr. Kean appeared for the moment to be overpowered by this spontaneous burst, but he manned himself speedily, and went through his arduous part with redoubled energy, taxed to its highest exertion. Every point was eagerly seized by the audience. The applause was almost unremitting. At the close of the great scene with his mother, which terminates the third act, Hamlet was loudly called for, and was obliged to appear before the curtain. The call was unanimously renewed at the termination of the tragedy, when Mr. Kean, having bowed his acknowledgments, retired. The audience were not satisfied with this. A continued and more enthusiastic demand for his return made it evident that he was expected to say something. He now felt it his duty to obey. Accordingly he addressed the house briefly, but pithily, as follows :-

" Ladies and gentlemen,-It is not my custom ever to address an audience, except on the concluding night of a seasoll; but I fear that were I not on the present occasion to respond to so unanimous an ebullition of public feeling as you have honoured me with this evening, my silence might be wrongly interpreted. I am deeply sensible of your kindness, and beg you to accept 
my heartfelt thanks. It would be affectation in me to pretend not to understand the motives which have influenced this particular excitement, and it is another convineing instance, in addition to the many $I$ have already received, that when a public man acts in a conscientious and upright manner, the public will always afford him their sympathy and support. Throughout my life I have coveted the verdict of public opinion, professionally and socially, and this evening impresses on me a most grateful conviction that my wishes are realized."

These few appropriate words, containing a world of condensed meaning, appeared to create a deep sensation, and produced a general repetition of the preceding applause. Several papers in articles on the erents of this evening, and with reference to the affair generally, suggested that some further elueidation would be desirable, and that Mr. Kean was, in fact, called upon to supply the defieiency. He thought differently, felt satisfied with the result, had no inelination to stir up a controversy that might lead to disrespectful conelusions, and remained silent. In a biographical work such as the present, and in treating of a remarkable incident in the life of an eminent professional man, the same reserve might seem to be affected and unnecessary, while it would incvitably lead to misconstruction. We therefore now state the facts as they oeeurred, without presuming to venture either comment or inference.

Soon after the plan was resolved on, Mr. Mitchell called upon Mr. Kean and proposed to him, as a matter of business, to perform "Macbeth" with his company, at the Italian Opera House. IIe stated that he had taken that theatre for the purpose of griving three or four dramatic and operatic representations during the 
festivities consequent on the Princess Royal's marriage ; that the scheme emanated from the Court, who had entrusted him with the details of carrying it out, and that it would receive the patronage of Her Majesty. He distinctly explained that this was a speculation, the loss or profit of which rested with himself, and that he might either win or lose a large sum of money. Mr. Kean asked whether Mr. Mitchell was instructed to make any overture for his co-operation from higher quarters, and was answered with an explicit negative. He requested a short time to consider the proposal, and in the course of the same evening replied in the following letter :-

"My dear Mr. MrtchelL,-

"I have given the subject you submitted to me this morning my deepest consideration, and regret extremely that the conclusion at which $I$ have arrived is opposed to your wishes as expressed to me.

"I cannot but feel that the arrangement you contemplate with regard to the Haymarket Opera House, must prove most detrimental to my interest in every way, and that in consequence I shall require all the attraction at my command to counteract such an overwhelming opposition. The absence of my professional services on the occasion in question can be of no possible consideration to you; for the very fact of your being so fortunate as to secure the exclusive permission of announcing Her Majesty's intended visits, must fill the theatre from floor to ceiling, without reference to the performers or performances. From my rcgard for you personally, and my high estimation of your character, I would waive any objection that did not involve so large a sacrifice; but as it is, the reasons for 
my present refusal to meet your views are unfortunately too numerous and too powerful.

"Yours truly,

"Charles Kean.*

This letter produced a second visit from Mr. Mitchell, who again endeavoured with much urgency to induce Mr. Kean to rescind his determination, and in the course of the conversation, implied that the Court would perhaps be annoyed at his refusal to co-operate. $\mathrm{Mr}$. Kean replied, "If this is your speculation, Mr. Mitchell, as a matter of business $I$ am justified in declining. If the Court were interested in it, as a matter of courtesy, in consideration of the position I have held for so many years as director of Her Majesty's private theatricals, I should assuredly have received some personal communication through the usual channel." These are the words that were used, for the writer was present at the intervicw. Mr. Kean then, to prevent any possibility of mistake, assured Mr. Mitchell that he had no wish whatcrer to impede his plans; that he would not have undertaken the speculation had it been proposed to him; and that even now, if the slightest indication should be conveyed to him that his services were desired, he would lay aside all objections, and instantly comply. Mr. Mitchell left him in evident anxiety to bring about this result, and with an expectation that it would be easy of accomplishment. In due course of time, the following letter decided the question.

- As a proof that Mr. Kean's professional opinion as to the injurious effect of these performances was justly based, it may le stated here that at that very period, usually the most productive of the London season, he sustained a loss of several thousand pounds. 
"Dear Mr. Kean,-

" London, Royal Library, Old Bond Street, " Dec. 7th, 1857.

"I had an interview with ....... on Saturday, and again to day. He seems quite unwilling to adopt my suggestions, and I therefore feel that I ought not to trouble you any further upon the subjeet.

"Yours faithfully

"JoHN Mitchell."

Here the matter ended. A eorrespondenee subsequently ensued between a gentleman of high position at the Court, and Mr. Kean; but being entirely of an unofficial character, Mr. Kean has declined admitting its introduction in these volumes.

It is quite true, as stated in some of the newspapers, that he proposed to open his theatre gratuitously to the publie, on a given night, to mark his respect for the occasion, provided it would suit her Majesty's convenienee to honour him with her presence. The arrangement was found to be impracticable. But another fact, no less true, was not stated in the papers, namely, that Mr. Kean conveyed, in the clearest terms, to the proper authorities, his readiness to obey the slightest indication of his royal mistress's wishes whieh might be communieated; but sueh an honour was not rouchsafed. There is no reason to deny that Mr. Kean did at the time feel decply pained by the little consideration extended towards him throughout these proeeedings. Can this be surprising? He had filled for many years, by express selection, the distinguished post of direetor of her Majesty's private theatrieals. In the discharge of that flattering, but at the same time, delicate and difficult duty, he had encountered heavy pecuniary loss, and many profes- 
sional annoyanees; but the coveted approbation of his august employers was dearer to his heart than all other considerations. Public and printed testimony have on more than one occasion been borne to the enthusiasm with which he has invariably prosecuted his art, and the total absence of selfish or mercenary fceling by which his actions have been governed. Let that evidenee now be corroborated by one who founds his knowledge on long and intimate acquaintanceship. In the case under immediate diseussion, Mr. Kean blended the double feeling of ardent loyalty to his queen, and an anxious desire to uphold the interests of his profession. Whatever might have been his personal convictions on the subject, all would have given way at once, had a single word implied the desire which would have been joyfully hailed as a command. 


\section{CHAPTER XII.}

TWO NEW FARCKS: THE STOCK EXCHANGE, OR THE GREEN BUSINESS, AND BAMUEL IN SEARCH OF HIMSELF ON EASTER MONDAY-REVIVAL OF KING LEAR, FROM THE TEXT OF SHAKESPEARE-TATE'S ALTERATIONGENERAL AND CRITICAL REMARKS-DEATH OF MRS. DAVISON, FORMERLY MISS DUNCAN-LAST PERFORMANCE AT THE OLD ADELPHI THEATRE IN THE STRAND-PECULIAR STYLE OF AUDIENCE, ACTORS, AND GUTHORSREVIVAL OF THE MERCHANT OF VENICE - NOVELTIES INTRODUCEDMR. KEAN'S SHYLOCK-MRS. C. KEAN'S PORTLA-GENERAL OBSERVATIONS ON THE PLAY, AND aCTORS OF THE PRINCIPAL CHARACTERS-THE NEW PRELUDE OF DYING FOR LOVE.

ON Easter Monday, April the 5th, 1858, "Faust and Marguerite" was re-produeed, after an interval of two years. There was no change in the cast. A new Comedietta, by Mr. Charles Dance, preceded the substantial dish of the evening; this was entitled "The Stock Exchange, or the Green Business;" and was received with marked approbation. Its success depended more on the excellence of blended acting than on the predominant effect of one or two parts. In this respect nothing could be better. "Samuel in search of himself" (by Mr. Sterling Coyne and Mr. Coape), which concluded the bill of fare, was farcical and extravagant to the last extreme, well adapted in the position assigned to it, for the purpose of sending an Easter audience "laughing to thcir beds." The title might have puzzled Edipus as far as regards analogy or association with the plot of this amusing bagatelle, which was much indebted for its success to the acting of our old friend Harley, fresh and mercurial 
to the last, as a novice of yesterday. "King Lear" was produeed by Mr. C. Kean on Saturday, the 17th of April. Lear is in many respects the most powerful of Shakespeare's glorious imaginings; this amounts to saying that it is the finest tragedy the human mind has ever conceived. The absolute palm, in the opinion of most critics, lies dubiously between Macbeth, Hamlet, Othello, and Lear. The poet's materials in Lear, as far as plot and incident extend, are derived from apoeryphal history and acknowledged fable. From Geoffrey of Monmouth, an authority of little value, although transeribed by Holingshed; from an older play, a preeeding ballad, and a tale in the "Areadia" of Sir Philip Sidney, which supplies the episode, so skilfully interwoven, of Gloucester and his sons. If we are to admit, which we are not disposed to do, that Shakespeare had but the narrow allowanee of classic learning so resolutely insisted on by Ben Jonson, Dr. Farmer, and others, he must, at least, have possessed an extensive acquaintance with English literature, and a memory as unbounded as his genius. On such substrata, collected from many mines, but amplified by his own exhaustless fancy, he created those umparalleled combinations of philosophy and poetry which have placed his name and works in a category by themselves. This power of transmuting rough materials to costly metal never has been, and we may safely predict, never will be equalled, execpt under direct inspiration.

Shakespeare enjoyed the happiness aceorded to few writers, of living fame, and his immortality may bid defiance to time and change. But after the Restoration, and throughout the profligate reigns of the Stuarts, he was nearly forgotten. In a list of more than fifty plays, enumerated by the theatrieal ehroniclers of the day, and running over a period of 
twenty years, from 1663 to 1683 , we discover only four of Shakespeare's, including Titus Andronicus. So thoroughly was the great poet lost sight of, that when Nahum Tate produced his mangled adaptation of "Lear," in 1681, he had the audacity to call it his own, and it was noticed as such, at a later period, in two numbers of the Tattler. This alteration became the established text, with trifling changes and omissions; it held possession of the stage for nearly a century and a half, from 1681 until within the last twenty years; and this spurious version was successively adopted by all the great actors, from Betterton, Booth, Garrick, and Barry, down to John Kemble and Edmund Kean inclusive.

“ King Lear," as prescnted at the Princess's Theatre, was considered by many as the most difficult triumph which Mr. Kean had yet accomplished. His historical lectures, for so the series of revivals might be denominated, have wrought a complete revolution in public taste, and placed Shakespeare on a loftier pinnacle than he ever occupied in those days so pathetically bemoaned by the advocates of supposed theatrical degeneracy, and worshipped by them and their followers as the age of giants, and the Augustan era of the British stage. Augean perhaps, would be a more appropriate term when we consider the mass of accumulated dross by which the genuine ore of the poet lad been so long corrupted, and the purifying process it had to go through.

In his arrangement of the text, Mr. Kean omits all repulsive and coarse passages, while the necessary condensation gives more rapidity to the tide of passion, and connects the incidents in an unbroken chain. The putting out of Gloster's cyes is one of those exceptional horrors that emulates the supper of Thyestes, or the 
visible murder of her children by Medea. This is merely glanced at in a few lines of dialogue, and thus a leading objection is removed without injury to the plot. Shakespeare has identified the story of the passionate old king and his three daughters with England, at a time when "the land was peopled with rude heathens, and the minds and hearts of men, as yet umreclaimed by the softening influences of Christianity, were barbarous and cruel," * No exact period is indicated, but Mrr. Kean has supposed a distinct era for the action of the play (the eighth century), sufficieutly remote to assimilate with the subject, but still within the scope of reliable authority for scenery and costume. When fact is so qualified by fiction that it is impossible to separate these conflicting ingredients, no extent of antiquarian perseverance can reach the minute accuracy which animates into living reflection the more certain age of King John, Richard II., or Henry VIII. Mr. Kean has so skilfully employed the resources which unwearied research enabled him to collect, that in the arrangements of this great drama-in the pictorial accompaniments, whether sylvan or architectural,-in the dresses, arms, and implements,-he presented us with an original picture of early Saxon England,fresh, glowing, and characteristic, which surprises and delights the eye, while it leaves on the mind the strong impression of historical truth. In all those points it is evident that $\mathrm{Mr}$. Kean trusts to no model, and refers to no previous example. He forms his own conception of Shakespeare's plays, casting aside all reminiscences of traditional precedent. Not satisfied to pursue the uncertain and ill-defined track which allured so many followers, he strikes out new paths with the hardiliood of intuitive genius. His mind travels with the time,

* Mr. Kean's preface. 
and adapts itself to the age that sits in judgment on his efforts. Instead of saying, "I will do this because it has been done before," we see clearly he says, "I will avoid all these crrors, for I know how they can be remedied;" and he may appeal to public opinion in testimony that his theory and practice are equally sound.

The originality so strongly manifested by Mr. C. Kean in his arrangement of the play, was even more conspicuous in his performance of the leading character; perhaps the most arduous on the stage, and the greatest touchstone of the actor's power which even the exhaustless imagination of Shakespeare has created. Lear presents an incarnation of impulsive passion-a temperament easily goaded to madness under the circumstances in which the poet has placed him. The sufferings he gocs through can only be relieved by death. How thoroughly we sympathise with Kent, when he closes the play with these impressive words :-

"Vex not his ghost ; oh, let him pass. He hates him That would upon the rack of this tough world Stretch him out longer."

In by-gone days the catastrophe was reversed, winding up with the happy marriage of Edgar and Cordelia (a mawkish interpolation), and the restoration of Lear, who was made to rejoice in his recovered authority. There were not wanting many who hailed the change as an improvement, and more who received it as genuine Shakespeare. The present age has been brought to a truer taste and a more just appreciation of the matchless bard; and not to all his predccessors combined are they so much indebted for the reform as to Mr. Charles Kean.

The part of Lear includes all the higher elements of tragedy under their most terrible attributes. It could 
only be undertaken, with the hope of a prosperous issue, by an actor who ranks in the very first elass, and combines an extraordinary union of mental and physical qualifications. It has been said often by professed critics, that "Lear" is a play that cannot be acted. We incline, on the contrary, to think that it is essentially an acting play; but its success or failure must entirely depend on the strength with which the leading character is delineated. The scenic appliances, the mechanicism of the storm, beautifully and picturesquely as they were employed in the present revival, would fade into nothing, unless the representative of Lear proved himself an Atlas, capable of bearing the entire weight of the tragedy on his own shoulders. The poet has giren him a task far beyond ordinary reach, and measured by his own gigantic standard. Mr. C. Kean did wisely to abstain from grappling with Lear until his judgment was ripened by long experience, and his powers mellowed to their full maturity. This is one of the parts that has been said, for several generations, to have died with its immediate representative. When an actor of eminence retires from the scene, it is usual to predict that, in certain characters, he will have no successor. At the funeral of Garrick, a devoted partisan, with more zeal than wisdom, sugrested that the play of "Hamlet" should be buried in his grave. Yet shortly after there came Henderson, and close on his footsteps, John Kemble, who inherited the laurels of the deceased Roscius in that very part, while yet his memory was green. When Cooke died, in 1812, it was loudly proclaimed that Sliylock and Richard had expired with him. But within two years up sprang Edmund Kean, who excelled him in both. He, too, has departed, and the proud dynasty of the Kembles is theatrically extinct; but in their places we have Charles Kean, the 
worthy son of an illustrious sire, who has placed his reputation as an actor of Shakespeare far above living competition, and has established his fame on an enduring basis, beyond all danger of subversion.

Mr. C. Kean's appearance in Lear was considered a challenge to criticism, which was freely accepted. He had every reason to be satisfied with the sentence pronounced by the enthusiastic public, and the more cautious exponents who lead or reflect public opinion. The general verdict was that he had equalled his Hamlet and Louis the Eleventh. It would be difficult to bestow higher praise. The performance was, in truth, a magnificent impersonation; not great by fits and starts, or marked by detached points, as was the case witl his father's, but a splendid and harmonious whole, combining the result of long experience with the quick, comprehensive genius, which not only seizes on the prominent features of a portrait, but can also find a charm, a grace, and an expressive meaning, in what may appear to a less subtle apprehension but as inferior and uncharacteristic lineaments. Mr. C. Kean's manner, gait, and costume, were all in perfect keeping, and indicated the most careful study. There was a tremulous cadence in his voice, with an occasional break, under progressive excitement, which conveyed most naturally the impression of old age without the fullness of decay. When the tide of feeling swelled into an overwhelming torrent, it poured from him without any exhibition of artistic prclude. He had not pronounced half-a-dozen speeches before it was clearly manifest to the audience that he had mastered the full range of the character, the sensibility of temperament, the hasty, extravagant passion, the blind, capricious impulsiveness, so readily goaded to insanity, -under excessive injury and insult. It is difficult to imagine the cffect with 
which, at the close of the first act, he uttered the celebrated curse on Goneril. To feel this truly, the actor must be followed through every preceding alternation of feeling, all of which converge to one point, and lead up to the climax. Mr. Kean's attitude and expression, when he flung down his hunting spear, and fell on his knees before he spoke, presented a picture worthy of the pencil of a Raphael. There is nothing in written language, ancient or modern, to compete with this tremendous imprecation. Lovers of Greek lore challenge equality for the malediction on his sons, in the " Edipus Coloneus of Sophocles." * French critics claim even superiority for the whirlwind of reproach with which Camille assails her vietorious brother in "Les Horaces" of Corneille. In our humble opinion, both wither into nothing when placed in direct comparison with Shakespeare.

Through the second act, the whirlwind of passion is kept up by Mr. Kean with increasing intensity, as successive indignities and new acts of ingratitude are heaped upon him at the hands of his second daugliter, Regan. He rushes distractedly into the storm, and here his reason begins to wander. The gradual advanee to the confirmed madness of the fourth act was finely discriminated; but if we are to name a particular passage for superior praise, where all was uniformly excellent, we must select the opening scene of the fifth act, in which Lear recovers his intellects, and recognizcs his daughter Cordelia. It was so natural and touching, that it excited the tears and plaudits of the house in equal proportions. After that, the aged sufferer has little to do but to expire of grief and worn-out nature,

* By an oblivious inconsistency, the deniers of Shakespeare's original genius and learning affirmed that he borrowed the idea of this passage from Sophocles. 
with the murdered Cordelia in his arms. A more perfect picture than this sad group, or one that more impressively embodies the substance of a "tragic volume," was never exhibited upon the stage.

The manager was well supported by his actors, who all appeared to have caught the true Shakespearean spirit. The Fool, one of the great poet's most delightful conceptions in that class, could not have been entrusted to a more pleasing representative than Miss Poole. Her scraps of old songs were artless and affeeting, and softened down with exquisite relief the agonising passion of the scenes in which they are introduced. The old masters omitted the Fool. Garrick feared the buffooneries of Woodward, to whom he thought of assigning it, and abandoned the idea. John Kemble and Edmund Kean found no Fool in Tate's version, and were content to lose him. Macready was the first who restored the character. Nothing was ever more dramatically effective than the contrast produced by the simplicity of this poor natural, the simulated frenzy of Mad Tom, and the gradual insanity of Lear.

Mr. Ryder's Edyar was a manly and effective performance. One of the weekly papers called it, " a fine sketch of Hanwell before the Conquest." Mr. Walter Lacy was a showy Edmund, and Mr. Cooper pourtrayed with chastened experience, the rough loyalty of Kent. Miss Kate Terry made an interesting Cordelia, and her two unamiable sisters, Goneril aud Regan, were represented with imposing beauty by Miss Heath and Miss Bufton.

On Thursday, the 10th of June, 1858, after thirtytwo consecutive repetitions, "King Lear" was withdrawn to make room for the "Merchant of Venice." Her Majesty and the Prince Consort were present on the concluding night, it being the fourth visit of the 
roval family to this noble tragedy. Why is it that "Lear," while exciting unbounded admiration, is less universally followed than other plays of inferior mark? Because, though surprising, it is unsatisfactory, and leaves an impression of pain on the spectator's mind that all the power of the poet's genius and the actor's art cannot alleviate. There is no female interest sufficient to soften the prevailing gloom. Cordelia is a beautiful sketch, but she is seldom seen. Goneril and Regan are unqualificd fiends, more wicked and repulsive than even Lady Macbeth. The latter has commanding energy in her crimes, and is at least faithful to her husband, with one touch of feeling in reference to his father.

The London papers of the first week of June, 1858, contained the following announcement, which was read with much regret by all who knew the subject of it privately, or remembered her in her professional eminence:- "On Sunday, May 30th, died at Brompton, Maria Rebceca Davison, formerly Miss Duncan, of the Theatres Royal, Drury Lane, Covent Garden, and Haymarket, aged seventy-eight, relict of the late James Darison, Esq. whom she survired ten weeks." Maria Duncan was the successor of Miss Farren, and for many years maintained her position as the first high comedy actress of the London stage. The original Juliana, in the "Honeymoon," and the best Lady Teazle, Lady Townly, Beatrice, Romp, Rosina, and Marian Ramsey, of her day. As a singer of Scotch ballads she was unrivalled. Her parents belonged to the theatrical profession, and it might almost be said she was born upon the stage. At five years of age, she acted the Dule of York, at Liverpool, to the Richard the Third of G. F. Cooke, and was highly complimented by the great ccentric star,-an unusual event, for he took little delight in infantine precocity. His contempt for the young 
Roscius was expressed in unmeasured diatribes; but then he writhed under the degradation of stooping to Glenalvon, while the boy towered above him in the interesting character of Norval. Miss Duncan, at thirteen, played Rosetta, in "Love in a Village," at Dublin, and soon became an established favourite in the Irish metropolis. Miss Farren saw her there as a mere child, and predicted her future success. But she had still to wait her time and opportunity. Seven years after Miss Farren had left the stage and become Countess of Derby, Mr. Wroughton, at that period stage manager of Drury Lane, happened accidentally to see Miss Duncan perform the Widow Cheerly (Soldier's Daughter), at Margate, and offered her at once a liberal engagement for the ensuing season. On the 8th of October, 1804, she appeared as Lady Teazle, the same character in which Miss Farren had retired. On that evening, Mathews and Elliston also performed, for the first time, Sir Peter Teazle and Charles Surface. Elliston had only commenced his career at Drury Lane a fortnight before, as Rolla, and was then looked upon as the rising actor of the day. The "School for Scandal" was repeated fifteen times. Miss Duncan followed Lady Teazle by Rosalind, Violante, Lady Townly, and Maria in the "Citizen;" but Mrs. Jordan was also in the company, and her presence somewhat restricted the opportunities of the new comer. On the 31st of Jannary, 1805 , in the same season, Tobin's posthumous comedy of the "Honeymoon" was produced, and ran for twenty-eight nights. The Duchess afforded Miss Dnncan the most desirable of all chances in theatrical life, a fine original character, of which she amply availed herself. Her performance in this part has never been approached by any succeeding actress. Her song at the commenecment of the fifth act, produced an unfailing encore; her style of dancing, graceful yet unaffected, and 
so agreeably contrasting the movements of the lady with those of the rustics with whom for the moment she was associated, proved one of the most attractive features in the comedy. In this, she was admirably seconded by Elliston, who danced with such elegance, that excellent light comedians afterwards were deterred from venturing on the Duke Aranza, because they lacked that accomplishment. Egerton, a heavy actor, selected it for his first London essay, and very nearly failed from his having neglected to worship the muse Terpsichore. Miss Dunean married Mr. Davison on the 31st of October, 1812. Ladies on the stage are apt to consider themselves more attractive under their maiden appellations, and often continue to retain them after they have become matrons. Miss Duncan had no such weakness. "An old Actress," who has written several amusing "recollections" in the Era (the faithful record of theatrieal doings), says of her departed friend:- "Her cliange of situation was kept a secret, and her marriage surprised every one. She was debating with me how she should be announced. We langhed at the expense of poor Mrs. G., whose husband, on account of falsc pride, would not suffer her real name to appear, and she was, therefore, announced as the late Miss Betterton. 'No, I will not,' said Maria, 'be the lute Miss Duncan, lest my friends, on seeing me act, should consider me but the ghost of my formcr self." "The same pen adds, "She remained on the stage for many years aftcr, nor quitted it until declining into the 'vale of years.' 'The last time I saw her on the boards was at the Haymarket (in 1825 ), in a piecc called 'Tribulation.' In one scene she and Dowton displayed some fine acting. 'Ah !' exclaimed Bamnister, who was of our party, 'we old ones did know how to do it!' and he loudly applauded these kindred spirits." 
On Wednesday, June the 2d, 1858, the last performance took place at the "little Adelphi," the doors of which were then closed, never again to open on the same edifice. One of the smallest and most incommodious of London theatres, it had long enjoyed a peculiar reputation. The Adelphi had its own audience, its own authors, actors, and pieces. In all these there was an uninterrupted family inheritance, never disputed, but duly descending from generation to generation. How many names of celebrity are conjured up to memory, when we glance hastily back on the fifty-three years' life of this celebrated histrionic temple, devoted to redhot melodrama, burlesque, domestic tales of intense interest, and "screaming farce." In its earliest epoch of celebrity it was called the Sans Pareil, managed by "true-blue Scott," as he was designated in popular phrase, with his daughter as the presiding goddess. Then succeeded Rodwell and Jones, under whom the "Tom and Jerry" mania reflected the taste of the day, and the freaks of "men on town" when George IV. was king. There was much wrenching of knockers and flooring of "Charlies" during this reign of slang and the back slums; but it helped to break up begging as a profitable investment, and certainly killed poor Billy Waters. After Rodwell and Jones came Terry, Mathews, and Yates, whose reign suggests reminiscences of Buckstone and Fitzball; of T. P. Cookc, O. Smith, Wilkinson, and Tyrone Power; of Wright and Paul Bedford; of Mrs. Yates, and Mrs. Keeley; of "The Pilot," "The Flying Dutchman," "The Wreek Ashore," "Victorine," "Rory O'More," and, though last not least, of "Jack Sheppard," which has since becn interdicted on the ground of its demoralizing example. In 1844, Mr. Webster became proprietor of the Adelphi, and appointed Madame Celeste as his 
directress. "Then," says a notice in the Times, "the same author who had maintained the dramatic character of the theatre during the 'Mathews and Yates ' period, came forward with his 'Green Bushes,' which may fairly be pronounced a perfect monster of success; inasmuch as fourteen years of scarcely interrupted wear and tear have proved insufficient to destroy its popularity. Many pieces have been brought out with various degrees of success since first Miami crossed the bridge, with her rifle on her shoulder, and Muster Greenidge and Jack Gong convulsed London with their eccentricities; but nevertheless, Mr. Buckstone's "Green Bushes" will always remain in the memory of the present generation of playgoers as the type of the old Adelphi. Nay, if in September next, Mr. B. Webster, according to ammouncement, opens a new Adelphi to the patronage of the public, a performance of this unfading piece will be regarded as a very legitimate house warming." The new Adelphi was not opened by Mr. Webster until the 26th of December, 1858, and is now one of the most clegant and commodious theatres in London.

There has been much disquisition and some severe homilies on the pernicions tendency of dramas of the "Tom and Jerry" and "Jack Sheppard" school. It cannot be said that they elevate the character of the stage, neither, perhaps, would it be easy to prove that they have permanently injured the morals of the public. They have died with the tastes and habits that inspired them, and may they long rest in peace. Their timehonoured prototype, the "Beggars' Opera," is now seldom brought forward. "The stage would lose nothing if it were finally buried and forgotten. Modern taste has no perception of the poignant satire which gave force to it when first written, and which has ceased to be 
understood or enjoyed with the times and individuals that have passed away.

On Saturday, June the 12th, the "Merchant of Venice," was revived: Mr. and Mrs. C. Kean taking their annual benefit on that evening. Actors and actresses of the highest rank have won clustering laurels as the representatives of Shylock and Portia. Macklin, Henderson, Cooke, and Edmund Kean have been indentified by past generations with " the Jew that Shakespeare drew." Mrs. Siddons first presented herself before a London audience as the accomplished heiress of Belmont, and frequently assumed the part in her riper years. In those days, and down to the present date, the "Merchant of Venice" was treated as a quiet, domestic drama, with some exquisite passages of poetry, and a scene or two of exciting passion; but it was never dreamed of as a vehicle for the most attractive and faithful pictorial embellishment, or as a medium for historical illustration equally delightful and instructive.

It would be impossible to produce a stronger contrast than that furnished by the presented subject when considered with reference to its immediate predecessor. Lear is all wild, romantic, rudely magnificent, painful in progress and catrastrophe; it touches the extreme verge of tragic pathos and almost extends to the horrible. The "Merchant of Venice," on the other hand, presents a continued series of softencd and delicious pictures; not all light, it is true, for then the surrounding glare would be intolerable, but with enough of shade and contrast to heighten while it relieves the prevailing brilliancy. The historical importance of Venice has passed away for ever; her palaces are crumbling, her gondolas glide silently througl the canals unenlivened by song; the haunt of merchants is 
no longer on the Rialto;-but the immortal verse of Shakespeare has invested the fair city of the sea with a charm for Englishmen which cannot perish with passing events, but which lives and blooms despite of political or national changes.

"For unto us she hath a spell beyond Her name in story, and her long array Of mighty shadows, whose dim forms despond Above the dogeless city's vanish'd sway; Ours is a trophy which will not decay With the Rialto ; Shylock and the Hoor, And Pierre, caunot be swept or worn awayThe keystones of the areh! though all were o'er, For us re-peopled were the solitary shore."

The "Merchant of Venice" has suffered less at the hands of mutilators than many of Shakespeare's equally popular dramas. Until Macklin restored the true rersion in 1741, a miserable imitation by Lord Lansdowne, called the "Jew of Venice," (in 1701) had superseded it as an aeting play. In this, Shylock was buffooned into a low comic character, performed by Dogget, grotesqueiy habited and vulgarised. It required sometime before the public could be reconciled to the change. As in the case of the Gravedigger's innumerable waistcoats in Hamlet, the galleries were unwilling to give up their traditional laugh. From the days of Macklin until Mr. C. Kean's revival, no one meddled with the text, and arrangement of the play, as the contemporary of Quin and Garrack had settled it. Macklin was a fine actor, in a very limited range, and an author of some literary pretensions-witness his comedy of the "Man of the World," and the farce of "Love à la Mode." But he was neither arehæologist, nor painter, nor poet, nor an enthusiast for historical accuracy ; and if he had been cither or all of all these, 
the age in which he lived could not have understood him. We have often felt surprised that Garrick never attempted Shylock. He would have done wonders in the part, with his fiery eye, his animated features, and his flexible voice. Perhaps he was deterred by the previous fame of Macklin, and unwilling to break a lance with so formidable a competitor.

Let us now consider what the taste and study of Mr. Kean have called into life from rich but hitherto neglected materials. The curtain draws up and we discover ourselves in Venice, the faned Queen of the Adriatic, "throned on her hundred Isles." Not represented as of old, by the traditionary pair of flats of Gothic aspect, symbolical alike of every age or country since the style was invented; but we see the actual square of St. Mark with the campanile and clock-tower, the cathedral, and the three standards, painted from drawings taken on the spot; restored, as in 1600, when Shakespeare wrote the play, and the incidents he has so skilfully interwoven are supposed to take place. Throngs of picturesquely-contrasted occupants gradually fill the area, passing and re-passing in their ordinary avocations. Nobles, citizens, inquisitors, foreigners, traders, water-carriers, and flower-girls are there; a flourish of trumpets announces the approach of the Doge, who issues in state procession, on his way to some public ceremony. The arrangement of the scene acts as an introductory prologue, and tells a story of identity which at ouce transplants us to the spot we are supposed to look on, and recals the era designated. Antonio and his companions, who open the play, come forward naturally from the surrounding groups, and commence the dialogue and acting. In all there was truthfulness and novelty; a riclness of couccption and a union of poetry, never before attempted or imagined, 
which, from the first moment, thoroughly engaged the attention of the audience.

The scene now shifts to the country residence of Portia, at Belmont, in which the saloon of the caskets presents a gorgeous picture of mediæval architecture and domestic luxury. Shylock is then introduced in the square of the Rialto, the exchange of Venice. Here was the real resort of merchants, and not the bridge, as some have erroneously supposed. The second act embraces a general view of Venice, taken from one of its most picturesque points, containing the canals, bridges, and gondolas, with all the peculiar localities and distinctive palaces that mark this strange city as a gem without a parallel. Here the abduction of Jessica takes place, in the midst of the frolic and bustle of a masquerade, as indicated by the words of the text. There have been many beautiful exhibitions of dancing and merriment in the Princess's Theatre, characteristic of various ages and countries; but none that in general estimation has equalled this. A Venetian carnival is a thing of itself, as distinct from any other street revel, from a bal masqué in the Opera House at Paris, from a country festival, or from an assembly in a private drawing-room, as can possibly be imagined. The great wonder is how, in so small a space, such an appearance of rast extent could be conveyed, and how so many groups, and such complicated morements, could be so gracefully organized.

The third act takes us again to Belmont, where Bassanio wins his lovely prize. In this portion of the play, too, we have the Rialto Bridge in its proper place, and no longer doing duty as the sole memorial by which Venice has, until now, been dramatically familiarized to us. The celebrated trial scene of the fourth act, where the poet puts forth all his strength, and the 
interest of the play is so finely worked up, takes place in the "Sala dei Pregadi," or Hall of the Senators, one of the most remarkable rooms in the seignorial palace. The architecture and ornaments are punctiliously preserved. The costumes are taken from indisputable authority ; but the stage arrangement is exclusively novel, and emanates entirely from Mr. Kean's profound knowledge of his art and managerial skill. He has utterly disregarded all conventional precedent, and, confiding in his own genius, has succeeded in embodying the most impressive court of justice that has ever been subjected to the criticism of a theatrical audience. We may readily imagine the amount of mind and physical exertion which must have been brought to bear to arrive at this perfect result. It is not alone by the acting of the principal characters, or by the superior intelligence of leading agents, that the harmonizing effect is produced. The dumb magnificoes, the subordinate officers, the clerks, heralds, and secretaries, the spectators crowded in the galleries and door-ways, all demonstrate the same interest in the gradual progress of the proceedings, and produce a succession of pictures in which nothing is out of keeping, but which satisfy the eye and critical judgment of the most fastidious artist, while they positively enchain the faculties of the general mass of beholders. The verse of Shakespeare tells with tenfold power when aided and expounded by these hitherto neglected accessories.

The chief interest of the "Merchant of Venice" undoubtedly ends witl the defeat of Shylock and the rescuc of Antonio. For this reason some sapient commentators, who persuade themselves that they could dictate improvements to Shakespeare, have denounced the last act as trifling and unnecessary. A few words 
of explanation, they say, at the close of the trial, would have sufficed to discover Portia and Nerissa to their husbands; and then the curtain should have dropped. Garrick was persuaded by reasoning similar to this, when he curtailed "Hamlet" of the two last acts, and wound up with the play scene. But, happily, the judgment of posterity has vindicated the original intention of the author. Nothing, to our taste, can be more natural and pleasing than the return to Belmont, in the play we are now noticing, and the mode in which the final explanation takes place. If the objectors could have witnessed the repose and harmony of the moonlight garden, provided by Mr. Gricve, and the lively grace of Mrs. Kean, in the equivoque included in the speeches of Portia, they would have felt, even if they wanted the grace to confess, that the great poet was a truer interpreter of his own mind, and a more consummate master in dramatic science, than they, with their mistaken crotchets.

In his veneration for the pure text of Shakespeare, Mr. Kean has been careful to avoid substituting an expression or a line not emanating from the original source. He has, of necessity, expunged a few coarse passages, which illustrate nothing beyond the colloquial style and manners of an cpoch less refined than the present. This comes under the head of purification, not omission, and takes nothing from strength, while it vindicates delicacy. The scenes of courtship by the Princes of Arragon and Morocco, had for many years been excluded from the acting play; why, it is too late as well as needless, to inquire; but their restoration is an important feature, which heightens the intercst attached to the episode of the caskets. They are material also to the complete development of the position, character, and feelings of Portia. Mr. Kean well knows the value of music and dancing, when those 
charming auxiliaries can be employed without violating consistency. The serenade under Jessica's window; the song, "Tell me, where is fancy bred?" while Bassanio is commenting silently before the caskets on which his fate depends; and the madrigal in the last act, in Portia's pleasure-grounds, are as appropriately introduced as they were pleasingly executed. The night carnival which terminates the second act equals the celebrated "Dionysia" in the "Winter's Tale," but in a totally different style; and is, in fact, such a passage from real life as could only be witnessed in Venice, or on the boards of the Princess's Theatre. What is there wanting in the "Merchant of Venice," as represented by Mr. Kean, that genius can conceive, art combine, or unlimited expenditure, regulated by elegant taste, accomplish? We have a play most ingeniously constructed, exquisite poetry, and vigorous delineation of character, which no mind but Shakespeare's could have monlded together; combined with acting of the most masterly description, heightened by all that painting, grouping, dressing, and stage arrangement can supply to complete a succession of pictures, harmonious in the general blending, and graphically distinct in each separate division. If any mortal appetite is not satisfied with this, and still requires more, the daughter of the horse-leech must cease to be quoted as a type of inordinate expectation.

Portia is one of the most fascinating of Shakespeare's female portraits. With a wise head on young shoulders, we love while we admire her, and envy Bassanio the certainty of his coming happiness. When we regard the feminine grace, purity, delicacy, and depth of feeling with which Shakespeare has so lavishly embellished his heroines; and when we remember, too, that in the days of dramatic infancy under which he wrote, his Violas, 
Rosalinds, Juliets, Desdemonas, and Ophelias, were personated by boys or bearded men," it would be worth the "jewel of Giamschid" or the Koh-i-noor to see him restored in the flesh for a single evening, to witness Mrs. C. Kean's delightful Portia. Our stage experience carries us a long way back, more years than there is any occasion to specify; but we remember no one who can be placed in comparison with her, taking into account all the varied qualities of this noble, and, at the same time, gentle and affectionate example of woman in her most attractive attributes. Comic actresses of celebrity have given infinite effect to the lighter passages, but have failed entirely in the great touchstone of the play - the trial scene. Under Garrick's reign, Mrs. Clive, unrivalled in her line as a chambermaid, a termagant, or a hoyden, was long permitted to burlesque Portia, for which she was utterly unsuited. When personating the doctor of laws, she gave imitations of the leading barristers of the day. Garrick felt the absurdity, but he lived under awe of her sarcastic wit, and dared not dispossess her of a part she held by prescriptive right and the favour of the public. On the other hand, some melancholy daughters of Melpomene, with smile as mournful as their sighs, in depicting faithfully the graver features of Portia, have lost sight of the unaffected ease and gaiety, the high tone of natural elegance, the inherent light-heartedness, with which the poet has gifted this charming creature of his faney. We know not in which her present representative displays the greatest excellence. In the garb and demeanour of the advocate, she was forensic wis-

"We all remember the aneclute of the apology made to Charles II., who hegan to tre impatient of delay, that the play could not begin until the Queen was shaved. 
dom personified. In her own palace, and in her natural habiliments, she looked and moved the princess, inspiring affection, while she commanded respect and obedience.

Shylock stands alone in the dramatic repertory. The part is short, and concentrated into three scenes, unlike any other from the same hand; intense, but not varied. He stands in complete isolation on the Shakespearean canvass. We never find him, or even a shadow of him, again. The passions of hatred and revenge, national and sectarian, in their strongest development, form the very essence of his nature. These are common enough in humanity; but, as the great master of the human heart has here depieted them, they assume a harrowing individuality which belongs to the one terrible exception. It is so with Mr. C. Kean's embodiment of the character. We cannot trace in it the slightest resemblance to any of the other great parts with which his name has become identified. There is not a sentence, an action, or a glance, suggestive of Hamlet, Macbeth, Lear, Wolsey, or Louis the Eleventh. By this faculty of abstract painting, this singleness of conception, when required, the actor proves, in the most convineing manner, his perfect sway over the art he practises, and his full intelligence of the author he undertakes to reflect. Weighed as dramatic metal, Shylock is all pure gold, without dross. He has no superfluous scenes, no supplemental speeehes, no diluted eloquence. He utters no syllable without a pungent meaning, and has a sarcasm in cvery sentence. Perpetual vituperation of his creed, his nation, and his calling, has moulded him into a concentrated retort, a sort of rolled-up porcupine, with his quills pointed in every direction. Some eritics found fault with Mr. C. Kean for showing, as they said, too much feeling,-for 
heightening the two or three passages that humanize this repulsive character. Why should he not? He has the text to guide him. Sliakespeare has made Shylock express affection for the memory of his wife, and place confidence in lis daughter. He entrusts her with his keys, and leaves her in charge of the house at night. He spits out venom, it is true, without measure; but always in reply, and never in attack. He is not malignant from stern nature, or without strong provocation.

The dramatic elements of Shylock are so clearly defined, that it would seem impossible for a man of talent to miss the intended effect; and yet although, with the exception of Garrick, all the lcading actors of successive ages have grappled with him, few have achieved a complete victory. It was Henderson's trial part before a London andience in 1777, at the Haymarket. Mackliu attended, and praised him as a debutant of promise. "I assure you, Sir," said the recruit, "that I never had the advantage of seeing you in this character." "I can readily belicve that," replicd the veteran; "if you had, you would have played very differently." Cooke, in 1800, almost effaced the memory of Henderson's Shylock. He was pronounced the legitimate suecessor of Macklin, until Edmund Kean rose like a meteor in 1814, and Cooke's warmest admirers acknowledged that he was beaten. Charles Kcan has now stepped into the place vacated by his father, to eomplete the quintumvirate of great Shylocks, and satisfy the world that the modern stage has not degenerated. The Kembles-John, Stephen, and Charles-each in their turus donned the gaberdine of the Jew; but they would have done more wiscly to have left it in the wardrobe. loung and Macready must be added to the list; but none of the 
last named five added anything to their reputations, while perhaps they disturbed the spirit of Shakespeare by wilfully flying in the face of their peculiar attributes. Legions of daring novices have broken down hopelessly in the ambitious experiment. There is all that can be desired in Mr. C. Kean's style, in his figure, his eye, his features, his distinct elocution, his epigrammatic terseness, his impassioned delivery, and his quick, expressive action, to fit him for complete success in this most striking and original impersonation.

Mr. Keau received more complimentary letters on his performance than would fill a small volume. We select one in particular, from high classical authority :-

" 11, Carlton House Terrace,
"July 14th, 185s.

"My dear Mr. KeAx,-

"Allow me to thank you very particularly, in my wife's name and my own, for the treat which the 'Merchant of Venice' afforded us last night. I have found in each of your representations from Shakespeare, that the individuality you give to every play effectually obviates all risk of sameness, either in the characters, or what is more difficult, in the mise en scène ; and that no new effort you have made disappoints, eren when subjected to the very severe test of comparison with its predecessors.

"Let me also thank Mrs. Kean for her large share in our gratification last evening.

"I am sorry that your very pressing employments have prevented us from meeting lately; but I trust that in another season Mrs. W. Gladstone and I may be morc fortunate.

"Believe me very faithfully yours,

"W. Gladstone. 
"P.S.-I should have wished to bestow many compliments on your ' King Lear' in particular, did I not feel that my ignorance and inexperience would render it presumptous."

Miss Chapman, a niece of Mrs. Kean's, made her first appearance on auy stage as Jessica. She was evidently oppressed by the embarrassment of her position, and rendered even more timid by the kind reception with which she was welcomed. Her appearance was extremely prepossessing, her voice sweet, and her manner untainted by affectation, evidently betokening a familiar acquaintance with good society.

On the 28th of June, the "Merchant of Venice" was heralded in by a lively trifle of French parentage, from the indcfatigable pen of Mr. J. M. Morton, under the name of "Dying for Love,"-a close translation of the original title, "Aimer et Mourir." The English adapter contrived to heighten the very slender matcrials with his usual characteristic humour. This little piece ran witl the "Mrerchant of Venice" to the close of the season. 


\section{CHAPTER XIII.}

DEATH OF THE CELEBRATED FREXCH ACTRESS MADEMOISELLE RACHEL, AT LE CANNET NEAR MONTPELLIER-SHORT SUMMARY OF HER THEATRICAL CAREER-HER ENORMOUS PROFITS IN A FEW XEARS-HER WILL, AND FUNERAL OBSEQUIES.

ON the night of Sunday, the 4th of July, 1858, Mademoiselle Rachel, the pride of the French stage, and one of the greatest tragic actresses of any country, died at Le Cannet, in the south of France, after a lingering and painful illness. Her repeated engagcments in London associate her name in some degrce with the English drama, and her world-wide reputation entitles her to a passing word in the theatrical reminiscences of the time. Young in days, but mature in fame, she was removed from the scene of her earthly triumphs before she had completed her thirty-eightlı year.

When Rachel returned from America in 1855, her health was so evidently broken, that her medical advisers at once pronounced her incapable of resuming the duties of her profession: She had caught cold by being too thinly attired at an evening party in New York, and the cold settled on her lungs. From that moment she never ceased to cough. The climate of Cairo was recommended as a last resource-a sentence almost as fatal as Madeira to the consumptive Englishman. To the banks of the Nile she accordingly repaired, in search of the anticipated amendment, which eluded her grasp; and after a fruitless sojourn she returned to 
die in the south of France. Not long before her demise, she recalled to her medical attendants an incident of the period of her greatest success. She was playing Phèdre, and the Bey of Tunis critically said of her, at the end of the piece, "She has a soul of fire in a body of gauze." It was with a melancholy sigh she remarked to her doctor, "Alas! he was right; and now you see that the fire has destroyed the gauze."

Many of the living generation may have seen and recollect Georges and Duchesnois. Rachel may be pronounced, on comparative evidence, superior to both. Her mien in the grand heroines of Greek and Roman tragedy was more severely classical. In feature, form, and attitude, in the arrangement of her drapery and the grace of her action, she presented the animated embodiment of a statue, fresh from the chisel of Chantrey or Canova.

Mademoiselle Rachel, or, more properly speaking, Elizabeth Rachel Felix (for such was her correct designation), was of Jewish descent and persuasion. She first saw the light on the 28th of February, 1821, in a miserable country inn at an obscure village called Munf, in the small canton of Arau, in Switzerland. Her father, a native of Metz, and her mother, whose maiden name was Esther Haya, followed the avocation of itinerant pedlars or hawkers, and for ten years after her birth were incessantly occupied in travelling through Switzerland and Germany. They encountered many privations in this peripatetic life, and struggled against a hard lot with fortitude and perseverance. Tired at last of wandering, they migrated with their family to Lyons, where Madame Fclix set up a stall for the sale of her goods, and Monsieur Felix attempted to teach an imitation of German. But customers and scholars came in slowly. Sarah, their 
eldest daughter, frequented the various coffee-houses, where she sang ballads, accompanied by herself on the guitar; while the little Rachel, her junior-assistant, went round the tables with a plate or a basket, to collect voluntary contributions.

In 1830 , the family made their way to Paris, poor, struggling, and unknown, with no internal consciousness or presentiment of the brilliant future which fortune had in store for them. In the metropolis of France they eked out existence much after the fashion they had followed at Lyons. Rachel, now increased in stature, executed duets with her sister throughout the day at the doors of public places, and in the evening brought home the diurnal receipts to the family garret in the Pláce de Grève. These homely details have been denied by injudicions flatterers; but the subject of them, with superior good sense and independent spirit, frequently related the particulars herself.

During this epoch, Etienne Choron, founder of the Royal Institution of Religious Music, chanced to encounter the young vocalists. He was struck by their natural gifts, and proposed to them to join his class. Rachel, of the two, had made the greatest impression on him, and in a consequent visit to her parents, he pressed for her in preference to Sarah. She became his pupil, and he pledged himself to take care of her advancement. Her names were then condensed into Elisa, to please her master.

In a short time it was discovered that her magnificent organ of voice, metallic, sonorous, and flcxible, was better adapted to produce startling effects in impassioned recitation, than in the more restricted field of scientific music. Whereupon Choron transferred his protégée to St. Aulaire, who trained up candidates for the stage at an establishment not connected with the Conser- 
vatoire. Rachel, up to this period, had received scarcely any education, and read with difficulty. St. Aulaire bestowed on her four years of careful tuition, and taught her, word by word, the parts of Hermione, Iphigenie, and Mary Stuart. But the pupil was perpetually at variance with her instructor. By a strange misconception of her own capabilities, her bent inclined to the chambermaids, or light heroines of comedya mistake to which she long continued to cling, in spite of experience and proved inferiority.

In October, 1836, Rachel became a pupil of the Conservatoire, in the class of Michelot. She was then in her seventeenth year, and her parents were impatient to turn her talent to current account. The wolf was seldom absent from their door. Their poverty increased with their increasing numbers.

Not many months after Elisa had become a member of the Conservatoire, Poirson, manager of the Gymnase, happened to be present at a represeutation of Racine's "Iphigenia in Aulis," which took place in the Salle Chantereine. The part of Eriphile was sustained on this occasion by the youthful Jewess. The character is not historical, but an interpolated creation of the author, of a very unamiable cast. It contains, nevertheless, dramatic force, with a grood spice of vindictive passion. The veteran saw, admired, and yielded to the power of an inexperienced novice. Nature spoke in her earnest tones, while strong feeling flashed from her dark eye. Poirson's receipts had for some time been dwindling down on a regularly graduatcd scale. His money chest was threatened with consumption. The usual frequenters of his theatre yawned over milk and water vaudevilles, and went elsewhere in search of more tickling food. He determined to lure them back, if possible, before his declining treasury was symbolized 
by an infinite decimal. A treaty was soon concluded with Monsieur Felix, for his daughter, on liberal terms, with an express stipulation that the common-place name of Elisa should be dropped for ever, and that of Rachel substituted in its place.

A new drama by Paul Duport, entitled "La Vendéenne," was ordered, written, and prepared for her first appearance. The press sounded the usual preliminary flourishes, the hour of trial arrived, the public crowded to the double novelty, but the result proved fatal to both. The piece and the debutante fell together. The part of La Vendéenne belonged to no defined class. It came within the range of comedy, was unsuited to Rachel's style, and afforded no scope for her peculiar attributes. The manager, in disappointment and indignation withdrew the play from the bills, and reduced his recruit to the ranks. Her spirit nearly sank under this unlooked for disgrace. The prospect of delivering messages instead of personating heroines, appeared to crush for ever her aspiring hopes. It was in vain that she applied to Vedel (director of the Théâtre Français) for succour or advice. He left her letters unanswered and avoided all personal interviews. He was, in fact, a mere titular monarch without power or prerogative beyond the empty name. The associated members of the Théâtre Français acknowledge a sovereign, but rule as viceroys over him. The government is a sort of oligarchical republic with a nominal head, - a Doge of Venice controlled by the Council of 'T'en.

Michelot, Rachel's master at the Conservatoire, looking upon her prospects as entirely marred by this false step, ceased to take any further interest in her fate. In despair, she had recourse to Provost, a leading comedian of the Thêâtre Français. He treated her pretensions with the most undisguised contempt, told her she 
would never become an actress, advised her to renounce all idea of the stage, and to sell bouquets or the Boulevards. Discouraged again, but not utterly beaten, she now repaired to Samson, the living Molière of the French drama, equally renowned as author and actor. Here she was more fortunate. He heard her recite, and his attention was speedily rivetted. He expressed the most unbounded admiration at the extent and quality of her voice, and undertook to train her up in the line which nature so imperatively indieated that she should follow. Governed by his sound experience she renouneed her favourite chamber-maids, and devoted her combined energies to the lofty range of tragedy. After a few months thus profitably employed, her clouded horizon began to brighteu. Vedel became more accessible, and having patehed up a truce with his refraetory confederates, was allowed for a time to exercise his own discretion. He wisely suffered his judgment to be led by the decided opinion of Samson.

Not long after, the bills and advertisements announced Mademoiselle Rachel, at the Théâtre Français, as $\mathrm{Ca}$ mille, in the far-famed "Horaces" of Corneille. It was a daring hazard for a young girl, damped by previous failure, and who had only completed the first quarter of her nineteenth year. The turning point of her destiny had now arrived. The chances were heavily against her, and the time of year the most unfavourable that the chapter of accidents could have selected. It was approaching midsummer, the intense heat had rendered Paris a desert; all the world was at the sea-side or in the country. The streets could have been shelled from the heights of Belleville or Montmartre without much loss of anything but ammunition.

A thinly seattered, listless, and unexpectant audience assembled at the Français on the erening of that 
eventful 12th of June, 1838. The stalls were deserted, and the voices of the actors reverberated back in hollow echoes from the thinly populated area of the pit and boxes. But in that small assemblage three individuals were included who could make or crush a reputation,-Dr. Veron, Merle, and Jules Janin, a triumvirate of critics, from whose sentences there was no appeal, and who governed theatrieal opinion in Paris as despotically as the Emperor of all the Russias enthrals the minds and bodies of his sixty millions of serfs. It pleased them on this occasion to be enthusiastic in praise. Janin, in partieular, indited an artiele in the Débats, which settled the question beyond cavil, and assured the success of the aspiring novice.

Within five months the new star was enabled to enumerate six distinet and successive triumphs in as many great and opposite characters. A seventh was yet wanting to the list, whieh Vedel persuaded her, with some misgiving, to undertake. Accordingly, on the 23d of November, 1838, she was announced for Roxane, in "Bajazet," an imperious virago, before whom Lady Macbeth and Clytemnastra sink into tameness;-another "adorable fury," as the French critics designate certain intemperate heroines of Corneille.

The associates of the company liad already began to boil over with jealousy, although their pockets were at the same time stuffed to unwonted repletion, as they shared in the managerial gains. But even money consoled them not for being partially eelipsed and placed on the shelf. Comedy, they exclaimed, was in danger of total extinction! and they were called upon, in the general interest, to make a stand before Rachel trampled them all under her feet. Several of the influential papers were induced to side with the malcontents. It was determined that Roxane should immolate Rachel. 
As soon as she appeared in this new character on the appointed evening, she became suddenly conscious of the conspiracy, and felt that it was serious by the coldness of her reception, the frozen temperament of the pit, and the whispering of the boxes. On this night, every paltry but calculated artifice which an envious and unmanly clique could think of, was put in practice to disconcert the actress and enfeeble her wonted execution. For the moment they prevailerl, and dragged down their intended victim far below the level of her usual standard. Even Jules Janin went over to the camp of the enemy, and published to the world in a laboured criticism that Roxane was a miserable failure. But, on the second performance, Rachel rose in her inherent strength despite all opposition, carried the unprejudiced portion of the audience with her in a whirlwind of applause, and, for once, the oracular dictum was disregarded as a malicious fallacy. At the third representation, the doors were crowded from an early hour; and, on the fourth, the receipts approached 300l. That evening she was nearly smothered under the storm of wreaths, coronets, and bouquets showered upon her from all parts of the house, as", she re-appeared in obedience to an enthusiastic call, after the tragedy had concluded. On the following day she piled the trophies in a carriage, and drove to the residence of Provost. "Buy some of these," said she, " since you advised me to sell them." "Forgive a false prophet," replied the old comedian with ready gallantry, " and seal his pardon with a kiss."

Rachel had now firmly cstablished her position. Conspiracy henceforward was treated with contempt, and she reigned without fear of rebellion or dethronement. The highest circles in Parisian society courted her acquaintance, and the most fashionable 
drawing-rooms received her as an honoured guest. In 1838, there existed in Paris a select coterie of a demireligious character, divided between the spiritual and the voluptuous, of which Madame Recamier, a living Ninon de l'Enclos, the ci-devant Venus of the Directory and Consulate, was president, and Chateaubriand an influential member. There were bishops and archbishops amongst them, and an imposing array of literary celebrities, male and female. This entire conclave ardently desired to convert the gifted and popular daughter of Israel. It would have been a notable achievement to win over such an illustrious neophyte to the bosom of the Catholic Church. Rachel astutely humoured the aspirations of her zealous patrons, and to mystify them more completely fell into their suggestion of studying the part of the Christian eonvert, Pauline, in Corneille's "Polyeucte Martyr." This professional stratagem was crowned with signal success. She won their sympathies, commanded their support, received their lavish presents-and remained true to the faith of her fathers.

The extraordinary and enduring attraction of Rachel appeared to justify the demand of unprecedented payment. In England, the leading theatrieal stars of the day make more by country engagements in a few weeks than they can command in the metropolis throughout a long season. London gives them the stamp and reputation by which they are enabled to work the provinees as an unfailing mine. It is the same in France, when they can get the opportunities, which are not so readily afforded. Leave of absence from Paris is more difficult to obtain, and absence without leave is visited by heavy forfeitures which are rigidly exacted, including loss of present pay and future pension. It is construed, too, into an act of contempt against the sovereign public, 
and would endanger the firmest popularity. Rachel, however, contrived after.some time to exact six months leave of absence every year; and, from 1845 onwards, the exercise of her talent produced something like $16,000 l$. per annum. Such a sum, so earned, for such a length of time, without material fluctuation, exceeds all that we know or have heard of in any other recent case, either at home or abroad, and rivals the recorded miracles of the gains amassed by two or three great actors, in ancient Rome.

There were other branches of the house of Felix, who now, as a natural consequence of Rachel's success, began to turn their thoughts to the stage, and determined to follow the line of life which had conducted their sister to such a store of wealth and fame. She as naturally responded to the call, and resolved to quarter them on the theatre. She thought it morally, politically, and religiously right to take care of her own. From the opening chapter of the human history down to the last, whenever it may be supplied, everybody has done, does, and will continue to do, the same thing. Right or wrong, the principle is supported by universal practice. Raphael, Felix, Sarah, Rebecea, and even the infant Dinah were successively enrolled in the company and borne on the treasurer's books, - assuredly far more than they were worth. Rachel could command engagements for her relations, but she was nnable to inoculate them with her genius. Scarcely a strip of her mantle descended on their shoulders, with an exception, perhaps, in favour of Rehecca, who gave indications of promise, but died prematurely. The public soon began to feel that they had rather too many of the family. Such a multiplicity of Hebrew designations appeared iu the bills, and so much Jewish physiognomy presented itself on the boards, that pcople no longer 
said, "Let us go to the Theâtre Français," but "Let us look in at the Synagogue."

The Siddons of the French stage (like our own) always rose in the delineation of terrible, majestic, and overwhelming rage with greater effect than when simple tenderness or grief was to be depicted, without any mixture of the sterner passions. She astonished the mind more intensely than she touched the heart, and called forth vociferous plaudits in greater abundance than the silent homage of tears. Her undisputed supremacy was achieved in characters of which the prominent features are, hatred, contempt, irony, rage, or despair. Those who have seen her as Camille in "Les Horaces," can never forget the thrilling burst of agony with which she wound up the celebrated imprecation against Rome, in the fourth act, addressed to her brother, when he returns victorious from the combat, after having slain her lover and betrothed husband.

It being Rachel's ambition to include in her range all the recognised heroines of the classical French drama, she continued from year to year to go through the entire series. In all she was powerful and original, but Phèdre has been generally pronounced her masterpiece, as it had formerly been considered that of her precursor, Duchesnois. The writer of this notice has seen them both, and perfectly recollects the peculiar excellences of each. Nothing could be more opposite than their appearance and manner. Little similarity could be traced, except in the effect, which was produced with equal force by different means. In quality of voice, and skill in modulation, they were nearly on a par; but Rachel had immeasurably the advantage of personal appearance. In the Phedre of Duchesnois you saw and felt a consummate actress, but in Rachel 
you looked upon and acknowledged the veritable presence of the guilty wife of Theseus, the poctical creation of Euripides and Racine, devoured by a passion beyond control, and enthralled by a fatal destiny which renders resistance hopeless. Both Duchesnois and Rachel reflected nature through the perfection of art, but the art was more skilfully concealed by the latter and younger representative.

It has been repeatedly said by Rachel's detractors (and whcre is the genius that can escape detraction?) that her talent was confined to a facility of execution; that she could do nothing without being taught, and possessed within herself no creative or imaginative power. That, in short, she was a mere parrot, quick to catch an oral impression, or to remember a lesson, but utterly without mental resources, and incapable of teaching herself. In support of this conclusion her defective education has been set forward as a leading argument. According to this censorious clique, whenever Rachel undertook a new part, she fled to her preceptor and adviser, Samson, from whom she imbibed the inspiration which she could adopt and appropriate with felicitous dexterity; but which, in the absence of superior intellect, she wanted the faculty of originating. At the close of the most harrowing performance, said these determined oppositionists, when the spectators were bewildered with conflicting emotions, the hand of Rachel was cold, her pulse beat no quicker than usual, her features were composed, and she exhibited no symptom of exhaustion from mental or physical fatigue. In opposition to the well-known eanon of Horace, she cxcited thousands to enthusiasm, without participating in the ferer she had caused.

These are extreme opinions, which confute themselves. Admit that this great artist, in common with 
many others, has had recourse to instruction, and received imparted ideas - whence came the variety which those who have seen her often and studied her closely, cannot fail to have observed in her delineations of the same character on different occasions? If she merely repeated a lesson acquired by rote, repetition might mellow but could not alter the manner in which that lesson would be delivered. It was always impossible to pronounce judgment on Rachel from her first performance of any given part. On such trials she was often uncertain of her effects, and not until the third or fourth experiment, when she had become confident in the soundness of her conception, could she be said to have discovered or put forth her full strength.

When Rachel obtained her first leave from the Théâtre Français in 1840, her earliest provincial visit was to the great commercial city of Lyons Here she produced a furor equal to that she had excited in Paris, and at the conclusion of her engagement, the enthusiastic functionaries of the corporation presented her with a coronet of massire gold, valued at 350 Napoleons. After a triumphal progress through many of the leading towns in France, in 1841 she repaired to London, and made her first appearance before an English audience at the Opera House in the Haymarket, then under the management of Laporte. Her attraction exceeded even the most sanguine expectations, and was crowned by the present of a magnificent ring from her majesty Queen Victoria, as a tribute to her professional excellence.

In the following year she came again to the same theatre, which had then passed into the hands of $\mathrm{Mr}$. Lumley. Between 1846 and 1853, she fulfilled five successive engagements with Mr. Mitchell at the St. James's, during which the London public had oppor- 
tunities of seeing her in nearly the entire range of her great characters. She brought many influential introductions, and at the outset, invitations poured upon her in abundance from fashionable and aristocratic circles; but after a season or two, although public admiration continued and increased, private attention received a check. During the summer of 1847, she appeared in Birmingham, Manchester, Liverpool, Edinburgh, and Glasgow. Negotiations were also at that time entered into with the Dublin manager; but $250 l$. per night, secured,-the sum proposed for herself and troupe-was considered too hazardous. If any one had then prophesied that within twelve months after, 1,500l. nightly would be averaged in the last-named city to five performances of Jenny Lind, at an unprecedented scale of prices, he would have been pronounced an incurable lunatic. Such is the unfathomable lottery of all theatrical speculation.

Notwithstanding the frozen climate of Russia, St. Petersburgh has invariably given a warm reception to foreign talent in every branch of art. Rachel was received in the northern capital with enthusiasm surpassing that which had been lavished on the most attractive of her predeeessors. She was applauded to the echo, fêted, adulated, and returned home laden with honours and riches, bending under the weight of roubles and diamonds. During her visit to Russia, the war broke out. Towards the conclusion of a grand dinner, to which she was invited as a parting compliment, some officers present, attached to the pcrsonal staff of the Czar Nicholas, indulged in vaunting anticipations of the approaching triumph of their master, and the certain humiliation of France and England. "To our speedy meeting again, Mademoisclle," exclaimed they, pledging the fair guest in bumpers; "we shall soon 
applaud you in Paris, and drink your health in the delicious wines of France." "Gentlemen," replied Rachel, "I thank you for your good wishes, but France is not rich enough to treat her prisoners with champagne."

Austria and Italy proved scarcely less remunerative to the all-enchanting daughter of Melpomene. Having, for the moment, exhausted Europe, she determined to glean America. Enormons sums were offered, as a certainty, for two hundred performances in the United States; but Rachel rejected them, and farmed herself out, as she had done before, to her brother Raphael, who had now amassed capital enough to venture on a more gigantic experiment in the New World, and entirely on his own responsibility. He miscalculated, and paid dearly for his error. All the indigenous managers united in a dead set against the intruding foreigner. $\mathrm{He}$ would have done more wisely to have coalesced with Barnum, or some practised speculator " native, and to the manner born;" success, then, might have been extorted by dexterous puffing. As it was, the whole matter eventuated in a sigual commercial failure: a result for which the heroine was totally unprepared.

Brother Jonathan bites rabidly at most of the baits that are held out to tempt him. . Music, in any language, fascinates his reason and imagination; but he is no pupil of Aristotle, has no faith in the unities, and is slow to appreciate Gallic filtrations of Sophocles and Euripides.

Whether from chagrin at this single defeat, or through the rapid inroads of organic disease which undermined her health, Rachel's performances were not resumed on her return to Europe. It was at Charleston that she played for the last time, and her concluding part was that of Adrienne Lecouvreur.

Despite the loss of time in America, and the uu- 
realized thousands she had calculated on, Rachel was generally reported to be deux fois millionaire; a grandiloqnent phrase, which translated into prosaic English, means that she had amassed one hundred thousand pounds sterling; - an almost incredible produce for less than fifteen years of labour. She bore the character of being parsimoniously inclined, except where her own relations were concerned. Towards these she ever practised the extreme of liberality. But her brothers and sisters in the profession, when engaged in her prorincial tours, complained that she paid them scantily, and worked them to death. She herself was indefatigable, and has often been known to act six times in the week, travelling, on occasion, twenty leagues from place to placc, and sleeping in her carriage.

This predominating love of money has been urged as an argument to show that she could not be endorred with the essential soul of genius. Avarice, according to those who reason thus, is incompatible with lofty intellect. It is a sordid, humiliating passion, as allabsorbing as it is base; which grovels on the earth in search of dross and vulgar treasure, while pure, etherial mind looks up to heaven, and loses itself in dreams of immortality. All this sounds well in poetry, but fails in practical illustration. Meanness in some things does not, of necessity, preclude clevation in others. The glorious philosophy of Bacon stooped to the contaminating influence of corruption; and this lamentable weakness has associated his name with a couplet of Pope that will never die :-

"If parts allare thee, think how Bacon shinil.

"The wisest, hrightest, neinest of mankinl."

Cassius was taunted by his intimate friend and brother with having "an itching palm;" the great Duke of rOL. II. 
Marlborough was known to be a worshipper of gold; and David Garrick bowed before his ingots, as to the household deities of his hearth. Yet the first was nevertheless a staunch patriot, the second an invincible general, and the third a pre-eminent actor.

The great French actress never set herself up as an Aspasia in learning, or advanced pretensions to more education than she really possessed. Count Mole, complimenting her one day in a strain of exaggerated flattery, on her pure elocution, said, "Mademoiselle, you have saved the French language." "If so, it is by chance," replied she, "for I have never been taught it." When the revolution of 1848 burst suddenly forth, and Louis Philippe, by his own mismanagement, suffered himself to be kicked from the throne he ought never to have occupied, Rachel became a red-hot patriot, in common with the infuriated million of Paris. Night after night she appeared, at the conclusion of the play, in a mixed military and Roman costume, and pealed forth the Marseillaise Hymn, with glowing republicanism, waving in her right hand the national standard. The novelty and the prevailing sentiment of the hour drew crowds to the strange exhibition; but when liberty and fraternity went down onee more under the memorable coup d'état of December, 1851, Rachel veered round in her tactics, and subsided into a fervent Napoleonist. Talleyrand himself, who made and broke at least twenty oaths of allegiance, never trimmed his timeserving loyalty with more adroitness. And why should blame attach to either? Dynastic and legislative changes in France may be considered as certain as the periodical returns of a comet, and much more speedy in rotation. No prudent citizen, therefore, should be condemned for swimning with a tide subjeet to so many variations. At the restoration of the Bourbons in 
1814 and 1815, the old soldiers of the Empire were compelled to mount the white emblem of the family; but every man kept the tri-coloured cockade in his knapsack, waiting to depose the lily with a moment's notice, on the first cry of "Vive l'Empereur." " Ready, aye ready," is a good political motto, which admits of a wide application.

In the theatre Rachel practised hauteur and reserve towards her assoeiates, and seldom entered the greenroom. The ante-chamber of her dressing apartment, sumptuously furnished, constituted her hall of audience. There between the acts, or at the close of her performance, she received visitors in queenly state. Ministers and ambassadors were to be found amongst her crowd of worshippers. At home her exclusive study was to please.

Young, renowned, rich, landsome, with the world at her feet, she might have married when and whom she pleased; but she adored the fame pertaining to her art too earnestly to surrender it up to domestie privaey ;her spirit was too independent to endure the ties and fetters by whieh ordinary natures consent to be bound.

It was currently said that Rachel had embraced the Roman Catholie faitl, and received the sacrament, a few days only before her death. This is contradieted by the fact that she was atteuded in her last moments by a Rabbi, and that her body being removed to Paris, was publicly buricd in the compartment of the cemetery of Père la Chaise appropriated to her people, according to the rites of Judaism. Her will, it was also said, and the general disposition of her vast property, would be disputed by some who thought they had a more legitinlate claim than the nominated legatees. When the ecflin that contained her mortal remains was lowcred into the earth, the Rabbi repeated aloud in Hetrew 
the prayer called Haskabe, and then another in French. Funeral orations were delivered by MM. Jules Janin, Bataille, and Maquet. M. Janin expressed his regret that the deceased was not eulogised by the only man competent to do so, but at present in exile, namely, Victor Hugo. The grave was then filled up, and the vast attending crowd returned to their daily avocations. 


\section{CHAPTER XIV.}

PROPOSAL FOR THE ESTABLISHMENT OF A DRAMATIC COLLEGE, OR ASYLUM FOR DECAYED ACTORS AND ACTRESSES - PUBLIC MEETING IN THE PRINCESS'S TREATRE, MR. C. KEAN IN THE CHAIR-REPORT OF PROCEEDINGS READ BY MR. CCLLEXFORD-SPEECHES BY IIR. C. KEAX, 31R. DICKENS, MR. CRESWICK, MR. T. P. COOKE, MR. HARLEY, MR. B. WEBSTER, MR. ROBERT BELL, SIR G. ARMYYTAGE, MR. F. MATTHEWS, AND SIK W. DE BATHE - PUBLISHED REPORT FOR 185\%, WITH AMOCNT OF SUBSCRIPTIONS - HER MAJESTY BECOMES PATRONESS-DIFFERENCE WITH MR. HEXRY DODD, AND FINAL REJECTION OF HIS OFFER-DEATH OF JOHY PRITT HARLEY-SOMMARY OF HIS CAREER-CLOSE OF THE SEASOY AT THE PRINCESS'S-MR. C. KEAY'S ADDRESS-GEYERAL OBSERVATIONS.

Ox Saturday, the 10th of July, 1858, a dramatic event occurred which it would be unpardonable not to record. Mr. Buckstone closed the Haymarket, after a season of little less than five years, and 1,427 acting nights. Throughout that long period, the theatre had remained open without interruption, except on Sundays, during the Passion Weeks, and on a few other occasional evenings prohibited by the Lord Chamberlain. The instance is without precedent, and will in all probability stand alone in future theatrical history.

In the course of the current year, a movement originated which had long been wanting to erase a reproach from the profession of the stage, that while every trade and calling had its asylum or house of refuge for destitute or disabled members, the actors alone formed an apparently careless or selfish exception. The spring, when once set in motion, accelerated in pace and strength with corresponding alacrity. 
On Wednesday, the 21st of July, 1858, a public meeting was held at the Royal Princess's Theatre, Charles Kean, Esq., F.S.A., in the chair, for the abovenamed purpose. The pit and gallery were thrown open to the public, and were crowded in every part; the boxes and stalls were occupied by those who had applied for tickets before the day of meeting; and the stage was titted up for the use of the Provisional Committee and reporters for the press. A great number of ladies were present, and added much to the beauty of the scene by the deep interest they appeared to take in the proeeedings.

On Mr. Kean's appearance on the stage, he received several rounds of applause; and when he proceeded to the performance of his duties as chairman of the meeting, those cheers were repeated. At a few minutes past one o'clock, he addressed the meeting as follows:-

"Ladies and Gentlemen, - The object of this meeting is to awaken public attention to a subject of very great interest to the members of the theatrical profession, and, if possible, to excite your sympathies, and to enlist your co-operation, in providing an asylum for some of those who, having long administered to your amusement, seek rest and comfort in the evening of their lives, for the brief space allotted to them after years of toil and trouble, before the dark shadow descends upon the dial of life. (Applause.) $\Lambda$ kind and benevolent gentleman, Mr. Henry Dodd, possessing landed property in Berkshire, has volunteered to give five freehold acres, for the purpose of building certain charitable houses for the reception of aged and worn-out brothers and sisters of the stage. In addition to the grant of land, I am permitted to state that this gentleman will also contribute one hundred guineas towards the erection of the 
houses. (Applause.) Assuredly we must all feel that in this instance wealth has been bestowed on one who truly understands the value of the blessing which Heaven has vouclisafed to him-to do good to his fellow-creatures, to supply the wants of the indigent, and to open a refuge for the aged and destitute. Under these circumstances, it is a duty we owe to ourselves to strain every nerve to assist this noble undertaking; and I cannot but feel that, as a professional body, we should be highly culpable were we in any degree to neglect carrying out such a disinterested intention. I will not detain you any longer for the present, but will call upon $\mathrm{Mr}$. Cullenford, our excellent and indefatigable secretary, to read the Report of the Provisional Committee, which will inform you of what has been done towards the establishment of this mucli-desired institution." (Cheers.)

Mr. Cullewfond read the Report, detailing the preliminary arrangements that had taken place, the appointment of a Provisional Committee, and the general scheme of the proposed institution.

Mr. KEAs then said: "Ladies and Gentlemen,-The proceedings of this meeting having thus far advanced, it becomes my duty to address a few words to you in behalf of the object we have in view. First, however, in the name of the Committee, allow me to thank you most sincerely for the honour you have conferred upon us by your presence here this day, and for the kind attention you have bestowed on the sulject in question -a subject which, you are well aware, is of serious import to the profession of the stage, and one which, if sucessfully carried out, will be the means of comforting many who, having passed the summer of their lives in your service, have nothing to cheer them, save through your help, during the barren and desolate 
winter which awaits the remnant of their days. (Applause.) It may appear strange that no charitable institution of the kind now proposed has as yet been erected for the reception of aged and worn-out members of the dramatic art. Almost every other cccupation of life can point to some such asylum for their decayed and broken associates; but for the actor there is no roof as yet prepared to shelter his white hairs-no home to receive his shattered frame-no haven of repose towards which he can direct his tottering steps. (Applause.) I would not for one moment presume to advance as a claim that which, I am sure, will spring from your own generous and benevolent impulses; but perhaps I may be excused if, on such an occasion, as an actor myselt, I derive some satisfaction in alluding to the obligations which England is under to actors. I do not refer to the long list of those distinguished performers whose great talents delighted your ancestors, and some of whose monuments now stand side by side with those of the most illustrious of our dead in the Abbey of Westminster;--(hear, hear) - but I wish to remind you of two important national legacies that have been bequeathed by actors-the legacy of deed, and the legacy of mind. That noble institution for youth, and asylum for age, Dulwich College-(applause)-was erected and endowed by the sole and unaided charity of one of the most honourable and respected men that ever drew the breath of life-Edward Alleyne, the actor;-(great applause)and what pride must we, as a protessional body, teel that the brightest literature of our country, the works of the most comprehensive mind that ever shed lustre on our history, have been left to us by an actor- II illiam Shakespeare. (Cheers.) Were it not for the stage, that mighty genius could not have found vent for the inspirations of his wondrous powers. 'That man, whose name 
is the pride of England-that marvel of the world, whose fame is the envy of the foreigner, while he bows in homage at his slirine-that man was an actor! (Applause.) The memory of these two celebrated persons alone should teach us all to reflect on the goodness and the greatness of which the stage is capable, and prompt the hearts of every English man and woman to encourage and cherish those who devote their lives to the development of an art which, when properly appreciated and properly protected, cannot fail to prove itself a source of national utility. (Loud applause.) Every human undertaking advances by progressive steps, and, in the words of our great poet,-

' We work by wit, and not by witcheraft, : And wit depends on dilatory time.'

"We do not expect that this project is to spring up in a complete form as if by magic, like Aladdin's palace; but what we ask this day is, that you will now sow the seed which hereafter may expand into a stately treethat you will lay the foundation-stone upon which may rise a goodly edifice. Let us hope that this meeting is but the begimning of the end, and that most of us now present may be spared to witness the prosperous results of this infant scheme, which under your auspices will grow into vigorous manhood. (Cheers.) Ladies and Gentlemen, throughout the varying series of dramatic representations provided for your amusement, from the lofty inspirations of Shakespeare to the lighter effusions of mirthful fancy, you see the members of each establishment who are endeavouring to afford you recreation from the more serious duties and trials of life-who are engaged for the time being possibly in relieving your minds from care and anxiety-you see them in the apparent enjoyment of health and strength. The vital 
spark burns strongly and brightly; but 'look upon this picture and on this!' Witness them in years to come, when health is broken and strength prostrated-infirm and aged-ill and in want-helpless and afflicted-no rest, no comfort, no joy, as they close their earthly scene; and then let the small, still voice within whisper - "To these I am indebted for years and years of service, in some instances perhaps for nearly half a century. They cry for help, and shall I deny them sympathy and assistance?' (Prolonged applause.) No; in the true spirit of Christianity, you will do muto others as you would they should do unto you. (Applause.) Let it be remembered that in our country the actor has no relianee but on the public. His only hope is in the hearts of his audience. Unlike the continental nations of Europe, the theatre here receives no annual subsidy, no pecuniary allowance from the Crown, the Government, or the municipal authorities. The actor's only recompense is your approval, his only pension your voluntary gift. (Hear, hear.) To the public he must look for support, and the British public never did and never will refuse to do that which is just and liberal in return for lives exhausted in their service. (Applause.) There arc hundreds of us, who, through the mercy of Providence, may never need this aid; and yet who can foresee the changes and vicissitudes that await us? But we plead for our poorer brethren, for those less fortunate and less strong, who by your bounty may thus be cnabled to look forward in old age to some prop on which they may lean with security, relieved from that mental disquietude which is ever engendered by the dread of privation and poverty. Through your help they will find a home for mind and body, where they may enjoy in peace the pleasing retrospect of former days, and prepare in tranquil resignation for the great 
and solemn change that awaits us all: (Applause.) You will not, I am sure, allow your feelings to evaporate in useless sensibility, but you will stretch forth to them the open hand of charity. To those less endowed with means, I would say, do not hesitate because your gift be trifling; great or small, as the widow's mite was acceptable, so will be your contribution. (Hear, hear.) 'The act blesses the giver and the receiver. The hour will come when we shall have to account for those gifts which Providence has lent to us on earth. At that solemn moment may the recording angel open the page wherein is written that you have comforted and relieved the aged and the destitute; that you have rewarded to the best of your ability the servants who have toiled for you; that you have vindicated one of the divine qualities which adorn the human heart-the quality of charity. (Applause.) May you unanimously respond to this appeal, and set an example here this day, which will be followed by thousands, and which only requires the moving impulse to arrive at a full and happy completion. Let us all bear in mind the beautiful and touching words of the Psalmist, "Blessed is he that considereth the poor and needy, the Lord shall deliver him in the time of trouble, and shall comfort him when he lieth sick upon his bed.' I will not further encroach upon your time and patience; I fear I have already too long detained you-('No, no,' and applause)-but I hope you will pardon the enthusiasm of one who feels deeply the canse he is endeavouring to plead. (Applause.) Before I resume my seat, allow me to state that, in addition to the benerolent donor's intentions, and the manner in which the Drury Lane and Covent Garden theatrical funds are disposed to assist this undertaking -(great applause) - I have this morning received a letter from Mr. Buckstone, the treasurer of the General 
Theatrical Fund, who is unavoidably detained in the country, to the effect that his fund is anxious to imitate the example of its elder sisters. If this arrangement, therefore, be carried out, we shall commence with three of the houses at once; and allow me to take the opportunity of saying, that it will afford me very sincere pleasure to hold myself responsible for the building of a fourth." (Cheers and waving of hats and handkerchiefs.)

Mr. CharLes Dickens : "Ladies and Gentlemen,-I think I may venture to congratulate you beforehand on the pleasant circumstance that the movers and seconders of the resolutions which will be submitted to you will probably have very little to say. Through the Report which you have heard read, and through the comprehensive address of the Chairman, the cause which brings us together has been so very clearly stated to you, that it can stand in need of very little, if of any, further exposition. But, as I have the honour to move the first resolution which this handsome gift, and the vigorous action that must be taken upon it, necessitate, I think I shall only give expression to what is uppermost in the general mind here, if I venture to remark that, many as the parts are in which Mr. Kean has distinguished himself on these boards, he has never appeared in one in which the large spirit of an artist, the feeling of a man, and the grace of a gentleman-(hear, hear)-have been more admirably blended than in his this day's faithful adherence to the calling of which he is a prosperous ornament, and in this day's manly advocacy of its eause. (Cheers.) Ladies and Gentlemen, the resolution entrusted to me is-

" "That the Report of the Provisional Committee be adopted, and that this meeting joyfully accepts, and gratefully acknowledges, the gift of tive acres of land referred to in the said Report.' 
- "It is manifest, I take it, that we are all agreed upon this acceptance and acknowledgment, and that we all know very well that this generous gift can inspire but one sentiment in the breast of all lovers of the dramatic art. As it is far too often forgotten by those who are indebted to it for many a restorative flight out of this working-day world, that the silks, and velvets, and elegant costumes of its professors must be every night exchanged for the hideous coats and waistcoats of the present day, in which we have now the honour and the misfortune of appearing before you-(cheers and laughter)-so, when we do meet with a nature so considerately generous as this donor's, and do find an interest in the real life and struggles of the people who have delighted it, so very spontaneous and so very. liberal, we have nothing to do but to accept and to admire: we have no duty left but to 'take the goods the gods provide us,' and to make the best and the most of them. Ladies and Gentlemen, allow me to remark, that in this mode of turning a good gift to the highest account, lies the truest gratitude. In reference to this, I conld not but reflect, whilst Mr. Kean was speaking, that in an houl or two from this time the spot upon which we are now assembled will be transformed into the scene of a crafty and a cruel bond. (Immense cheering, which Jasted for some time.) I knew that, a few lours hence, the grand canal of Venice will flow, with picturesque fidelity, on the very spot on which I now stand dryshod, and that 'the quality of mercy' will be beautifully stated to the Venctian Council by a learned young doctor from Padua; -on these rery boards on which we now enlarge upon the quality of charity and sympatly. Knowing this, it came into my mind to consider how different the real bond of to-day from the ideal bond of to-night. Now, all generosity, all forbearance, all for- 
getfulness of little jealousies and unworthy divisions, all united action for the general good. Then, all selfishness, all malignity, all cruelty, all revenge, and all evil, -now all good. Then, a bond to be broken within the compass of a few,- - three or four,--swiftly passing hours, - now, a bond to be valid and of good effect generations hence. (Great cheering.) Ladies and Gentlemen, of the execution and delivery of this bond, between this generous gentleman on the one hand, and the united members of a too often and too long disunited art upon the other, be you the witnesses. Do you attest of everything that is liberal and free in spirit, that it is "so nominated in the bond;' and of everything that is grudging, self-seeking, unjust, or unfair, that it is by no sophistry ever to be found there. I beg to move the resolution which I have already had the pleasure of reading." (Loud and continued cheering.)

The resolution, which Mr. W. Cueswick seconded, was carried unanimously.

Mr. T. P. Cooke, seconded by Mr. Harley, proposed :-

"That Charles Kean, Benjamin Webster, Charles Dickens, and W. M. Thackeray, Esqs., be elected Trustees of the said College."

Mr. Benjamin Webster: "Previously, Ladies and Gentlemen, to proposing the third resolution, I am appointed to thank you for your approval of the four names submitted to you as trustees of this proposed-I think I may say carried-Institution; and to assure you that the endeavours of those trustees will be used to carry the object to its utmost extent. I wish that for your advantage one of those named who is absent from us, Mr. 'Thaekeray, had been here to thank you instead 
of myself, but cireumstances have occurred which prevent his desired appearance here to-day. I know it will be your loss, and not my gain, for I lack the power of speech of that gifted gentleman. But I will yield in earnestness of purpose, and earnestness of hope for a brighter future for this profession, to no man, be he high or low. (Applause.) I feel it a great honour to hold the post of 'Trustee to this College, and so, I am sure, do my companions in that office. I thank you in their names, and in my own; and the more responsibility you give to that office by your liberality, the more you increase the honour you have conferred upon us. I have now to propose to you the third resolution, which is in these words:-

" "That a subscription be entered into for the purpose of carrying out the gift of the donor and the intention of the Provisional Committee, and of forwarding the benevolent objeet for which we are assembled.'

"After the eloquent speeches which have been addressed to you, which so ably defined the end and objc ct of our assembling here, a few words from me will suftice. I am egotistical enough to believe that many here know my humble efforts to obtain a few crumbs for the poor player from the very rich table of Dulwich College ('Hear, hear,' and cheers); but though all I prayed for was most cheerfully granted by the four parishes having the right to its benefit under Alleyne's will, more was thought of building a church-though one existed there sufficient, as it was proved, for all the requirements of the parish-endowing it with 300l. a year out of the earnings of the profine stage-player, and placing it in the gift of the Archbishop of Canterbury, than coneeding a paltry 100l. out of nearly a million and a quarter of wealth, to fonr worn-out actors and actresses, and educating eight of their children; and this, too, in the face 
of the fact that Alleyne originally commenced the College for actors and their families. I trust that the result has given birth in some degree to this landable donation. When I looked around upon the numerous colleges, institutions, and hospitals for young and old, specially devoted to certain trades and professions, I did feel that there was an exception to my class, but your presence here to-day proves such an exception to have been undeserved. (Loud cheers.) It has been the constant purpose of my life to see an institution similar to Dulwich College for the care-worn members of our much-neglected and much-abused profession, having practically known many of the trials and many of the vicissitudes and necessities of an actor's life. I may be allowed to state, Ladies and Gentlemen, that in my long experience as manager, actor, and a man of the world, I have known no class who, from the highest to the lowest employé in the establishment, give more bountifully to the unfortunate brother than the actor. Now if, indeed, charity be a cloak, let it cover the many errors that ignorance and fanaticism unjustly heap upon our calling. Thank Heaven, there are liundreds, thousands, nay millions, who do and will stand by us, even to the highest in the realm, as the following admirably written letter, in answer to a request that her Majesty would become our Patroness, will amply prove:-

" 'Osborne, July 16th, 1858.

" Mr dear Mr. Webster,-I have had the honour to lay before her Majesty the Queen the papers which accompanied your letter to me of the 15 th inst. I have received the commands of her Majesty to say to you in reply, that her Majesty would take much interest in any plan for rendering more comfortable the declining years of actresses and actors who are suffering under insufficient 
means (great applause); and the Queen would wish every success to the undertaking of which you have forwarded the prospectus. The seheme is not, however, as yet sufficiently advanced for her Majesty to become its Patroness. The Queen has always required, before she grants the use of her name to any new eharity, that not only shall the object be a deserving one, but that it shall have been sufficiently appreciated and supported by the public to give a reasonable security that the institution shall be prosperous and permanent. When, therefore, your plans have acquired a little more substantive character, and there is good evidence of a cordial and general support, you will be at liberty to apply to me again for her Majesty's patronage.-Sincerely yours,

“ 'B. Webster, Esq.' (Cheers.)

$$
\text { "C. B. Phipps. }
$$

"Ladies and Gentlemen, that is the highest honour that could be eonferred upon us; and so deeply am I interested in this cause, that without any attempt at ostentation, I will give, from large masses of stone I have in Wales-approved, good stone-sufficient to face the whole of the twenty tenements, and the whole of the stone required for the collegiate school. But the vitality of the entire building is in your hands-at least I hope so, in the shape of pounds, shillings, and pence, and I trust the figures will speak for themselves more to the purpose than I have."

Mr. Webster concluded by moving the resolution, which was seconded in an extremely eloquent speech by Mr. Robert Bell.

Sir Geolege Arurtafe moved, "That Messrs. Coutts and Company be the bankers, at the West-end, and Mesirs. Rubarts, Curtis, and Company, in the City."

VUL. II. 
Mr. Frank Matthews seconded the resolution, which was carried unanimously.

The Secretary then read the list of subscriptions already received, amounting to nearly $900 l$.

Sir Williaar De Bathe, seconded by Mr. Brady, M.P., proposed "That the thanks of this meeting are hereby given to Charles Kean, Esq., for his impartial and efficient services as Chairman of this meeting, and for his kindness in offering the use of his theatre." (Cheers.)

Mr. KEAN having acknowledged the compliment, the proceedings terminated.

Within a few weeks after the meeting at the Princess's Theatre, the Committee published their first Report, containing the gratifying announcement that her Majesty the Queen had graciously given her consent to become Patroness, accompanied by a donation of $100 \%$. 'The entire amount collected at that date reached $1,852 l$., without including annual subscriptions to the extent of $215 l$. more. Nothing could be more encouraging than the commencement and prospect. But clouds soon began to gather, and from a quarter where they were least to be expected. The gentleman so highly complimented as the first mover of the scheme, and donor of the land, evinced through his solicitor a disposition to fence round his free gift with legal restrictions and stipulations which apprised the Committee of coming difficulty. After some correspondence of a very unsatisfactory nature, a general meeting of the subscribers was held on the 13th of Jauuary, 1859, in the Adelphi Theatre, which had been placed at the disposal of the Provisional Committee by Mr. B. Webster. Their Report was then read, containing a full account of all the proceedings that had taken place. The chair was taken at one o'clock by Lord Tenterden, a nobleman who had always evinced strong sympathies with the members of the dramatic 
art. The meeting adopted a unanimous resolution to repudiate Mr. Henry Dodd, and to consider and accept one of two offers of the necessary land made by the Rev. Edward Moore, and the London Necropolis Company. The well-wishers to the cause will have no reason to regret the momentary check, which gave rise to much spontaneous sympathy. Out of evil comes good. Sir William De Bathe and several gentlemen present volunteered at once to supply 507. each, as a separate fund for the purchase of ground without favour or obligation; and many members also proposed to double their subscriptions for the same purpose. It was stated at this second meeting that the sum then in hand amounted to $3,000 l$., and the annual subscriptions to $250 l$. That the intended College so auspiciously projected will advance rapidly towards completion may be considered as certain as that the canse is charity, and its success involves our national character. At a later meeting, it was finally resolved to accept the ground offered near Woking, by the London Necropolis Company. The first stone of the building is expected to be laid in September next.

Few names will be more missed firom the playbills, than that of John Pritt Ilarley, who died, we may say suddenly, at his residence in Gower-street, on Sunday, the 22nd of August, 1858. He very nearly added another to the list of actors who have fallen "in hamess." Harley was the son of a highly respectable draper and silk-mercer, in the parish of St. Jartin-in-the-Fields, where he was himself born. He was intended for the medical profession, and afterwards for the law, but an innate attachment to the drama, rigidly curbed by his nearest relatives, gratified itself with the first opportunity; and some juvenile efforts meeting with warm encouragement, determined his future life. His regular theatrical carcer may be dated from April. 1808, when he became 
a member of Mr. Trotter's company, then manager of the Gravesend, Worthing, and Brighton theatres. From thence he migrated to the York cireuit, succeeding to the ample line of comic charaeters vacated by Fawcett, Mathews, Emery, and Knight. In the summer of 1815, having returned to Brighton, he was seen and engaged by Mr. Arnold for the then Lyceum 'Theatre, where he appeared on the 15 th of July, as Marcelli, in the manager's opera of the "Devil's Bridge," and Peter Fidget, in Beazley's farce of the "Boarding House." During the same year, as we have already mentioned, he established his winter quarters at Drury-lane, and made a most successful introduction on the 16th of September. Bannister's farewell benefit had taken place on the 1st of June preceding, so that a wide field was open to rising ability.

At Drury Lane, with occasional excursions to the country and engagements at the Lyceum, where he for some time undertook the duties of stage manager, Harley remained for more than twenty years, until Mr. Braham opened the St. James's Theatre, in 1836, when he joined the company formed by that gentleman. He soon after, however, returned to his old quarters, and was with Mr. Macready, at Covent Garden, in 183S, and afterwards with Madame Vestris and MIr. Charles Mathews when they opened the same establishment two vears later. He then joined $\mathrm{Mr}$. Bunn at Drury Lane, and finally, when Mr. Charles Kean made his great effort to restore the fortunes of the legitimate drama at the Princess's Theatre, in 1850, he gave in his adhesion to the cause, and remained from that period an active and prominent member of the company. His last original part was Peter Pounce, in the faree called "Samuel in search of Himself." He succeeded Edmund Kean as master of the Drury Lane theatrical fund, and held that office until his death. 
Harley rose rapidly in public favour ; in liumour and versatility he almost equalled his model, Bannister, the general round of whose characters he successfully filled. His rising reputation was greatly assisted by original parts in successful farces, amongst which may be enumerated Jack Phantom, in "Frightened to Deatlı;" Popolino, in the "Sleeping Drauglit;" and Amoroso, King of Little Britain in the burlesque of the same name. In 1816, when "Every Man in his Humour" was revived for Edmund Kean's Kitely, Harley sustained Brliadil, a great attempt for one comparatively new to the London boards, and was thought by many to be the best that had appeared since the days of Woodward. In the Shakespearean clowns he had a quaint natural humour peculiar to himself, flowing without effort, and copied from no example, but the product of his own conception, and embodied according to his physical attributes. No actor, not even Munden or Liston, ever excited more genuine laughter. It was impossible to feel dull when Harley was upon the stage. The exercise of his art appeared delightful to himself, and imparted spontaneous gratification to his audience. He was the very opposite of what is understood by the terms, a dry, laborious, hard-working actor. Such men literally drag out attention, and earn their fame and money by throes and painful earnestness; but they rarcly cause the pulse of the spectator to quicken, or his thoughts to lose for a time all conscionsness of the outward cares of life. IIarley was one of the last representatives and disciples of a genuine style, which younger aspirants would do wiscly to study, before the few survivors of the generation have entirely passed away. The recption with which our old friend was invariably grectcd, must have convineed lim in the most conclusive manner that ancient favorites are not forgotten because fresher candidates may happen 
to be in the field, and that in spite of the railway speed of modern improvernent, the old school could stand by the new and lose no ground.

The name of Harley was identified with an extensive range of parts which no one could touch like himself. They form a numerous family, and were looked upon as his personal property. We know not to whom he could have bequeathed them, or who can claim legitimate succession as heir at law, now that a reversion has occurred. On Friday, the 20th of August, he acted Launcelot Gobbo with unusual spirit, and in reply to one or two observations as to how well he seemed, answered that he never felt better. Of the numerous audience on that night assembled at the Princess's 'Theatre, not one who enjoyed the grotesque activity with which he skipped across the bridge when dismissed by Shylock, imagined that they looked and laughed for the last time, and that the fiat had gone forth destined so rapidly to close his earthly eareer. As he reached the wing he was seized with paralysis of the left side, and with assistance reached the green-room where he was laid on the sofa. Medical aid being immediately provided, the case was pronounced imminent, and as soon as possible he was conveyed to his own house in Gower-street, his sister and only surviving relative (since dead) being previously apprised by Mr. Ellis, the stage manager, that an accident had happened to him. In a few hours he lost recollection, sank gradually, and expired, apparently without suffering or effort, on the afternoon of Sunday, the 22nd August. The last coherent words he uttered were a quotation from the "Midsummer Night's Dream," "I have an exposition of sleep come upon me." It is not to be supposed that he thereby indicated any conscionsness of his approaching end. It was merely the utterance of a familiar passage with regard to his 
immediate sensation of drowsiness. Something similar occurred when John Wesley was dangerously ill and supposed to be at the point of death in Ireland, and whose mind could scarcely be expected to be imbued with the imagery of Shakespeare. Observing the countenance of a lady who sat by his side endeavouring to conceal her emotion under assumed tranquillity, he looked towards her and said, "She sits like Patience on a monument, smiling at Grief.'

Different statements lave appeared as to Harley's age. We have reason to believe, on good authority, that had he lived to reach another birthday he would have completed seventy-three. He had also long been accounted one of the rich men of the stage, but this, to the surprise of all, was found to be erroneous. Except lis furniture and personal effects he had no realized property. Yet he had received large sums, was not known to indulge in extravagant propensities, or to have suffered by speculation. At one time he had a very considerable investment in the funds. How did he dispose of his superfluity? This is a mystery not likely to be unravelled. Great mistakes are often made as to the savings of actors, which are not unfrequently estimated at more than they have ever received. Harley's life must have been happy beyond the ordinary lot. He was respected and liked by all who knew liim. He had a merry heart, an equal temper, and an interminable fund of anecdote, enjoying society, and contributing his full share in lively conversation. IIe had never encumbered himself with the cares of a family, remaining unmarried throughout a long and successful professional career, in which he encountered but a small share of the ordinary rubs and disappointments. It secms rather a remarkable coincidence that only a few weeks before, his friend and comrade Bartley died at nearly the same 
age and from a similar attack. Bartley, however, laboured under a heart complaint, so that his sudden demise might have been more readily looked for. But when men have reached and passed the term named by the Psalmist, and may be supposed to be ready for the great change, it matters little whether a learned disease with a hard name, the sudden rupture of a vital chord, or mere exhausted nature, is the proximate cause of their departure.

The long and brilliant season at the Princess's Theatre terminated on the evening of the 3rd of September, when the "Merchant of Venice" was presented to a crowded house with undiminished effect, and for the seventy-second time without intermission. Had not a short interval of rest been absolutely necessary, this beautiful play would, in all probability, have run on to the full completion of one hundred nights-the ordinary term of a Princess's Shakespearean revival. When the curtain fell on the last scene, Mr. and Mrs. C. Kean were unanimously summoned to receive a parting compliment, after which Mr. C. Kean came forward alone, and took his temporary leave of the audience in the following short but emphatic speech :-

"Ladies and Gentlemen,-At the close of each successive season it has ever been my custom to address a few words to you in thankfulness for your kind support. The present year, from various circumstances, in part unavoidable, and in part. unexpected, has been to me a period of great respons bility, anxiety, and fatigue; relieved, however, by evidences and expressions of public feeling and sympathy, the memory of which can only fade with life. Contrary to my original intention, I feel compelled, from the mental and bodily strain I have ndergone, to seek a few weeks of comparative repose, 
that I may be the better able to bring to a successful termination my next and last season.

"Permit me, therefore, to take this opportunity of announcing my intention to re-open this house on Saturday, the $2 d$ of October; and at the same time to state that, on the 29th of August next, I shall take my final leave as director of the Princess's Theatre. In the meantime, Ladies and Gentlemen, allow me, in Mrs. Kean's name, as well as my own, respectfully and gratefully to bid you farewell."

The season, we have said, was brilliant; so it was in exertion and apparent effect. We wish we could add, successful, in a pecuniary sense. But to this it was diametrically opposed, the loss exceeding 4,0007. A casual observer and occasional visitor who sees a crowded house, considers one sample an index of the whole, but he knows nothing of the enormous outlay and nightly expense, which too often exceed the aggregate returns. The local causes of deficiency, in the present instance, may be eliefly traced to the American failures, which paralysed the commereial world, to an Italian Opera at cheap prices, through the entire winter, and to the "Festival Performances," which drained the purses of the theatrical constituency, and abstracted large sums from their legitimate recipients.

In the course of the eleven months' duration of the expired season, nineteen different pices were played, of which four only were new; the pantomime and three farces. Out of two hundred and sixty-nine acting nights, there were only forty-two not devoted to Shakespeare.

Every human discovery and improvement, all that idvances philosophy, science, literature, or mechanical mrention, is doomed to undergo the three successive 
phases of opposition, ridicule, and adoption. Mr. C. Kean has pre-eminently illustrated this fact in the progress of his professional life. His claims, long and obstinately contested, are at length universally admitted. His restorations of Shakespeare are received as the most truthful homage ever rendered to the greatest genius that England or the world has produced. His fertile mind and extensive scholarship have ealled into life effects never before imagined; whilst his versatile embodiments of so many great characters in the Shakespearian range have identified him, as an actor, with the Garricks, Hendersons, and Kembles of bygone ages, and more especially with his own father, who, in two or three leading elements, excelled them all.

It is too often the lot of living merit-and the condition is a hard one-to be treated with injustice; to be undervalued until a gap, not easily filled, impresses the importance of a public loss, and the difficulty of filling up a vacancy. Then follows the selfish regret and unavailing penitence which mourns the absence of a possession, the full value of which is only ascertained when lost beyond recovery; extorted tears to consecrate the ashes of the dead, instead of the spontaneous tribute which ought to soothe and adorn the presence of the living; a posthumous instalment on a just debt, which, however flattering to his heirs, is paid too late to gratify the silent creditor. There are such things, too, as personal enmities, neither forgotten nor foregone until they can be no longer indulged. More fortunate than many who seek the temple of fame, Mr. C. Kean has not had to wait for this tardy acknowledgment. His merits and services as a public teacher are frecly conceded, and he enjoys the universal respect which attaches to unblemished private character and rare professional excellence. 
Throughout the season of 1857-1858, Mr. Kean's name was seldom absent from the bills. Night after night he delighted the public with such varied performances as Prospero, Richard II., Hamlet, Louis II., Mephistopheles, King Lear, and Shylock. It is seldon that a great actor and manager, when he has won the double reputation, the acknowledged supremacy, for which he has so perseveringly toiled, continues to impose on himself the physical labour, which, if carried too far, would break down the strongest constitution. Garriek and John Kemble, for many year's before their retirement, acted only twice or thrice a week, at particular portions of the season. They reposed on their laurels; but they remembered also that-

" Time hath a wallet at his back,

Wherein he puts alms for oblivion ;:

A great siz'l monster of ingratitudes :

And to have done, is to hang

Quite ont of fashion, like a rusty mail,

In monumental mockery."

'They therefore took care to present themselves now and then on select occasions, to keep curiosity alive, to prevent its being entirely attracted towards others, and to watch their own fame, lest it should tarnish by disuse. But Mr. C. Kean during his period of management never allowed himself an intermitting relief. He resembled a sentinel continually at his post, and worked with as much untiring perseverance as in the days of his early novitiate when slowly climbing up the steps of the ladder. Such constant exertion could only be sustained by that inborn enthusiasm which is ever the accompaniment of true genius. It is a fact which includes a flattering compliment, while at the same time it imposes a harassing condition, that although supported by an excellent working company, few plays 
were found to be attractive at the Princess's Theatre, unless the names of Mr. and Mrs. C. Kean were included in the cast. Here is at once a conclusive argument in reply to the diminishing but still pertinacious section of cavillers, who are ready with an objection for everything, and have so long endeavoured to maintain that accessorial embellishment has injured genuine art, and that the most important figures in the painting are obscured by the gorgeousness of the surrounding framework. Take away such representatives of Shakespeare's heroes and heroines as Mr. and Mrs. C. Kean, and there prejudiced Zoili would soon have it rendered palpable to them, that the upholsterer and property man (those favourite figures for a sneer), the scene-painter and mechanist, are incompetent to touch the hearts of an audience, or to vindicate the superiority of our matchless mover of the passions. When the intricate machinery of a watch is brought into harmony by mechanical skill, it is the mainspring alone that can set the whole in action ; break that, and all the rest becomes torpid and ineffective. It is precisely thus with the blended elements of a represented play. The scenery, the costumes, the architecture, the arrangement of incidental groups, the evolutions of well-trained supernumeraries, the most accurate historical reflection of bygone ages and manners, - all these adjuncts may be called into use, and restored as perfectly as classical taste and antiquarian knowledge can reproduce them: but still, the life-like reality, the animating charm, the mainspring in fact, lies exclusively witlin the faculty of acting. Let the performers who are set down for the great parts, fall below the corresponding level which the genius of the poet demands, and it has ever been scen that they become indistinctly confused with the figures in the background, and the entire picture fades into vapid 
mediocrity. Without acting of a very high order, no extent of pictorial embellishment could command one hundred successive repetitions of a Shakespearean drama. It is only by a well-balanced union of forees that the effeet is produced. Divide these forces, and weakness supersedes power. "The hairs in a horse's tail," says Dr. Donne, in a quaint comparison, "concur in a single root of beauty and strength; but being separated and plucked out one by one, they lose all value, and serve for little better than springes and snares." 


\section{CHAPTER XV.}

MR. C. KEANS FAREWELl SEASON AS MANAGER OF THE PRINCESS'S THEATRE-MERCHANT OF VENICE CONTINUED-SECOND REVIVAL OF KING JOHN-DITTO OF MACBETH-PRODUCTION OF MUCH ADO ABOUT NOTHING-MR. AND MRS. C. KEAN AS BENEDICK AND BEATRICF-FARCE OF THIRTY-THREE NEXT BIRTHDAX-PANTOMIME OF THE KING OF THE CASTLE-JEALOUS WIFE-CORSICAN BROTHERS-MIDSUMMER NIGHT'S DREAM-LOUIS THE ELEVENTH- HAMLET.

A SHORT recess of four wecks passed rapidly over, and on Saturday, the 2nd of October, 1858, Mr. C. Kean opened his last campaign as manager of the Prineess's Theatre, with the seventy-third representation of the "Merchant of Venice," preceded by the farce of " Dying for Love." Once more the curtain rose on the Queen of the Adriatic in all her reanimated glory. The enthusiastic welcome with which Mr. and Mrs. Kean were greeted on their appearance, told emphatically the feeling of the public, and spoke in a combined voice of estimation and antieipated regret. 'Two changes had taken place in the cast of the play. Nerissa was now acted, and very agreeably, by Miss Bufton, a young lady of considerable promise and personal attractions, who improves rapidly with experience. $M r$. Saker succeeded the lamented Harley, as Launcelot Gobbo, and deserves his full meed of praise for a careful study of a part, difficult under such peculiar cireumstances.

To give as much variety as possible to his concluding season, Mr. Kean determined to repeat, in quick succession, a series of his principal Shakesperean revivals. 
Accordingly, in a fortnight, the "Merchant of Venice," on the 17th of October, gave place to "King John," which had not been represented since 1852. Nothing could be more complete than the change. From the anks of the Brenta and the sunny skies of Italy,trom the gay frolics of the carnival, and the stately, mediæval magnificence of the "dogeless" city,-Mr. Kean, by a single wave of his managerial wand, carried us into other regions and more distant times; recalling our thoughts to fix them on a remarkable though not glorious period of domestic history. We were now in the stormy era of the Plantagenets, and found ourselves treading the baronial halls and palaces of Norman Fngland, or listening to the war-blast on the old battle-fields of Anjou and Kent.

We have three plays on the subject of King John. 'The first, anonymous, earlier than Shakespeare's (in 1591), and which by some speculators has been attributed to Marlowe. An action for libel would almost lie on the insinuation. Here Shakespeare found the plot, characters, and incidents. These he freely used; but the nervous language, the glowing thought, the power, the pathos, and the passion, are all his own, and could not have emanated from any other source. There is not a single spark of either in the poor and vulgar origrinal. In 1745, old Colley Cibber, fired with the mania of improving Shakespeare, inflicted on the town a pernicious imitation, entitled, "Papal Tyranny in the reign of King John." On this memorable occasion, the ancient laureat, who had lost his teeth, returned to the stage, and mumbled through Cardinal Pandulph; but the affair died a natural death, and its failure had this advantage, that, since then, no sacrilegious invader has ventured to substitute his crambe repetita for the genuine text of Shakespeare. During the last liundred 
years, "King John" has been repeatedly brought forward under successive and rival dynasties, but with mistakes and shortcomings to the last; until Mr. C. Kean, in 1852 , inaugurated his new system with a more perfect revival than had yet been presented by the most highlygifted of his predecessors. As now re-produced, the play had the advantage of his own intermediate experience, with the high finish of those powers of acting which have grown by progressive steps to their complete development.

Although far from the best in Shakespeare's historical series, "King John" has characters of startling power, and passages of poetic beauty, equal to any that he has written elsewhere. When he selected this subject, we have often wondered that he did not ascend a little higher in time, and choose the popular and stirring. epoch which immediately preceded,-the reign of the lion-hearted Richard. Here was a monarch more in accordance with English notions of regal heroism; and his death by the hand of the archer Bertrand de Gourdon, at the siege of the Castle of Chaluz, with his dying mercy to the man by whose hand he was prematurely cut off, although not carried out after his decease, would have supplied a catastrophe more dramatically striking, and less repulsive than the expiring agonies of his miserable brother. The moral in either case is nearly the same-the transient nature of earthly grandeur, and the emptiness of all human ambition.

The foreign policy of John was timid and inglorious; the domestic troubles of his reign invariably resulted from his own overweening tyranny. Sliakespeare has entirely passed over all allusion to the great national Charter, which the English barons wrung from their cowardly but despotic master. He may have done this from delicacy towards the absolutists of his own 
day, Elizabeth and James, who were also his personal patrons; but at all events he moulded to his own purposes the other incidents in the reign of King John with the scenic arrangement of the old play, scattering about in rich profusion his own liarmonious verse, his vigorous passion, and his boundless amplification of mind and feeling. He lias engrafted no new characters, but he has gloriously heightened the rough sketches he found in a barren soil. We cannot revel in reminiscences which stir an Englishman's blood, and fillip his pride, when our thoughts revert to this dark period of our national annals. But it must not be denied, and may be profitably studied and remembered. Truly refreshing it is to find the living reality evoked on the boards of the Princess's Theatre, in the form of the most agreeable intellectual lesson, and with all the stately adjuncts by which instruction can be seasoned and recommended.

It is not easy to estimate Mr. C. Kean's performance of the regal felon of the line of Anjou by any fixed analysis, or comparative standard of excellence. Again, he presented us with a complete and unique portrait, which we can trace to no particular family, or antecedent class. The English monarch is to the full as wicked and remorseless as Louis the Eleventh ; but our thoughts never revert to the one while witnessing the same evil passions depicted in the mind and person of the other. John is a compound of every contemptible and loathsome attribute, either as man or monarch; ambitious and cruel to the last extreme; not absolutely a coward in the field, but a moral poltroon in the conduct of life; helpless and abject in adversity; covetous, overbearing, and impolitic when fortune smiles on him: a strange blending of opposite qualities, which nevertheless often meet, exhibiting fool and knave in alternating proporVO L. II. 
tions. During his whole existence, as brought before us by Shakespeare, we find nothing to admire, and as he expires under the racking agonies of poison, while we pay our just tribute to the power of his dramatic representative, we feel relieved by the departure of the man.

The pervading gloom of the play is felicitously relieved by the humorous, dare-devil gallantry of Falconbridge, who vindicates his royal blood, and becomes even dignified as his responsibility increases. But the softening charm lies with Constance and Arthur. Fortune dealt hardly with them. Holinshed relates that Arthur was imprisoned at Rouen, when he was supposed to be murdered, as some said, by his uncle's own hand. He was an adult youth and not a child, as Shakespeare has represented him. This is certainly an important deviation from fact, but by this poetic licence the bard has invested his supplications to Hubert with the simplicity of infantine innocence, and has given us one of the most affecting scenes he ever imagined. Again, the veritable Lady Constance of history demands our respect and sympathy with less compelling influence than the wronged widow and bereaved parent, so powerfully transferred to the dramatic canvas. Maternal anguish and despair have never been so naturally conceived, or so pathetically expressed, as in the Constance of Shakespeare. Enthusiasts in classic lore may turn to the Clytemnostra, Hecuba, and Andromache of Euripides,-but they will seek in vain for those heartrending exclamations, those overwhelming touches of nature, which lacerate the hearts of the audience, until they find relief in tears. Her apostrophe to death, beginning, " amiable, lovely death," in her last scene, is superior to that fine invocation of the chorus in the "Supplicants" of Asschylus, to the same power. There 
is nothing in the French imitators of the ancients, in the most vaunted passages of Corneille or Racine, to be taken into comparison. Voltaire affected to ridicule Shakespeare, and tried to make his countrymen follow his example. The French themselves look upon their cold declamatory tragedies as perfect in construction and dialogue. English taste judges them by a standard very distinct from the scholastics of Aristotle. Accustomed to the uncontrolled flights of Shakespeare, we set little value on unities and classical restrictions. We acknowledge readily the transcendent powers of a Rachel and a Talma, while we wish they had better materials to work with, and varieties of character to delineate more in accordance with the ordinary sympathies and feelings of humanity.

Such a noble part as Constance requires a great representative, and on looking down the annals of the stage, we find the names of Mrs. Cibber, Mrs. Yates, Mrs. Siddons, and Miss O'Neill, successively identified with the widow of Geoffrey. Mrs. C. Kean has put forth a proud claim to be associated with this honoured list, and the claim will be unanimously conceded. Her performance is truly wonderful-by far the finest female portraiture on the living stage, and by many degrees her own chef-d'auvre. How different from the playful elegance of Portia, and yet how thoroughly and intensely Shakespercan! It is worth going a hundred miles to see, and will be required to be seen again and again before its beauties can be felt or understood as they deserve. Young actresses will do well to study this accomplished mistress of her art, while they have yct an opportunity, for such a model is not likely to be supplied to them again.

Next to Constance and King John, Falconbridge, Hubert, and Young Arthur, stand prominently forward 
as characters of importance. All three were well personated by Mr. Walter Lacy, Mr. Ryder, and Miss Ellen Terry, who succeeded her elder sister. Every part was in the hands of an adequate performer. The entire cast bore evidence of the completeness of the Princess's company, so soon destined to be dispersed, and never again united under the same banner.

Macbeth was revived on Monday, the 1st of November, and performed alternately with "KingJohn" for some weeks. Five years had elapsed since its first production by Mr. Kean, but nearly all the principal characters were still in the same hands, the changes being chiefly amongst the rank and file.

A quarter of a century hence, when the events of to-day will have subsided into records of the past, the generation of the then present hour may possibly estimate at a truer value than we do now, the results of Mr. C. Kean's eight years, of what may be exclusively called Shakespearean management, at the Princess's theatre. Time, the universal purifier, can alone decide the question, as to how far national taste, refinement, education, and manners, may have derived a permanent and a beneficial impulse from a source hitherto undervalued, or entirely passed over in the philosophical speculations and practical theories of teachers, preachers, and orators of every class; always on the alert to enlighten and advance the world, but not invariably happy in the means recommended to promote the desired end.

We do not believe it possible that any thinking person should see such a dramatic exhibition as "Macbeth," at the Princess's theatre, without an impression that there must be something in this beyond "a show," and that the delightful recreation thus imparted, is not a fiction of the hour, to make the labourer forget his 
toil, the student relax his overwrought abstraction, or the constitutionally indolent rouse up his torpid faculties; but that it combines a profound moral, and has in it an instructive power, which elevates thought and feeling, and tends to make man happier as well as better. Some will smile, deriding this as mere enthusiasm, and it may be that it is so; but without enthusiasm the world would be but a weary road to travel on, and many would faint under their appointed trial.

Shakespeare has taken his materials for "Macbeth" from Holinshed. The subject is well adapted to a dramatic poet's purpose. It has all that his form of composition requires-situations and characters powerfully contrasted, events rising in interest, each growing out of the other and leading up to the catastrophe. The intermingling of supernatural agency was never so appropriate. The weak point in Nacbeth's character is superstition, and on that weakness he gradually falls into the fathomless abyss of crime. Read the chronicle, and what can be more bald and meagre than the manner in which the events are related. They contain the argument and outline of a dramatic poem, but no colouring. See the play, and who does not feel the sublimity of thought, the harrowing intensity, the redundant images, the practical reflections, the majestic poetry, once heard never to be forgotten, which the genius of Shakespeare has called into life, and consigned to his lawful heirs, the actors, to perpetuate by their executive skill. To find anything to compare with " Macbeth," we must go hack to Eschylus, Sophocles, and Euripides. There we may find glimmerings of kindred inspiration, but we shall seek in vain for them nearer our own times. Let us descend from Greece to Rome, in her best days of poetic pretension. Is there any spark of Shakespeare's muse in the dull, laboured tragedies of Seneca, or who- 
ever may have written them in his name? None, that we could ever discover. What is there of similar genius in the crude metaphysics of Schiller? Not a scintillation. What in the Frenchified classicality of Corneille? In spite of our respect for M. Guizot's critical acumen, we look upon the attempt to set up a parallel between the father of the French stage and the father of ours as literary profanation almost demanding criminal proceedings. It is futile to endeavour to silence us, as Voltaire tried to do a century ago, by charges of violations of the unities, breaches of decorum, sins of anachronism, the coarseness of here and there a conventional phrase, or the carelessness of rapid composition. In answer to all these pop-gun batteries, we oppose the unapproachable beauties of the poetry, the profound philosophy and moral, the majestic scope of the invention, which imagined new worlds when old ones were exhausted, and distanced time himself in the race for immortality. In fine, we say, show us a poem or a play equal to "Macbeth," taken in all its components and bearings, in the collected literature of the world.

When Mr. C. Kean enters as Macbeth, he gives the key-note of the character before he has spoken a dozen lines. He prepares us for the description which his wife subsequently gives of him :--

" Thou wouldst be great;

Art not without ambition; but without

The illness should attend it. What thon wouldst highly,

That wouldst thou holily ; wouldst not play false,

And yet wouldst wrongly win."

After his interview with the witches he never loses the bewildered look of a man whose mind has been shaken by a supernatural encounter, and a congenial prophecy. He still has energy and manliness of soul, 
but he has lost confidence in himself, and is no longer sure of anything. The agitation of his mind resembles the rolling of the sea in a storm. He fights and struggles yet, but he is under a fatal influence,-the prediction of the witches, and the stinging excitements of his wife. His nature is good, but he yields to the double attack. He is brave but superstitious; differing entirely from Richard the Third, who is naturally callous and void of conscience. Macheth subsides into crime; and though we abhor his deeds, we think and feel he had that within him which ought to have shaped a better course. His despairing energy in the fifth act clothes his fall with something approaching to dignity. Such is Shakespeare's "Macbeth," as reflected by Mr. C. Kean. Some of his predecessors have been wonderfully great in insulated scenes; but, as an entire performance, sound judges place his above them all. We have seen many Macbeths, and the peculiarities of each come back upon us with the freshness of an event of yesterday. Of those who flourished in the ages of our fathers and grandfathers, the records are so ample and minute, that we are as familiar with them as if they also had fallen within our personal observation. Mr. C. Kcall, it is true, has the advantage of scenic accompaniments, pictorial accuracy, and historical costume, which impart a reality to the action, very imperfectly sought for in earlicr days. But let the merit of this rest with himself, for the idea and application are as much lis own as the effect is unprecedented.

Lady Nacbeth is associated with her partner throughout the play. The image and presence of the wife cannot be separated from her help-mate. 'The chronicle gives but a few lines indicative of her disposition. She is called the stimulatress of her husband to his first deed of blood,- " a woman very ambitious, burning 
with an unquenchable desire to bear the name of "queen." This slight groundwork is wrought up by Shakespeare into a character of such dramatic power, so repulsive, but irresistibly imposing, that it throws into the shade the finest relics of the Greek tragedians, those vaunted masters and models of the grand and terrific. Compared to Lady Macbeth, Clytemncestra or Medea are angels of peace and gentleness. Yet there is no part on the stage that can win more applause by the commanding strength of her mind and the vigour of her language. But for her remorse in the end, darkly hinted through the incoherent murmurings of her sleep, we should be tempted to reject her as an alien to the human family. It is Shakespeare and not history that has irradiated this dark heroine with the single flash of humanity, by which the unmingled savageness of her heart is brightened. She would have slain the unconscious Duncan herself, when she stole into his chamber, and laid the daggers ready for her husband's use. With the swiftness of lightning the infernal suggestion flashed across her mind, but nature spoke for once;--" he resembled her father as he slept," and her murderous hand became paralysed.

In some of the Memoirs of Mrs. Siddons, or in her published correspondence, we have read that her notion of Lady Macbeth's personal appearance depicted her as a woman of small stature, with light hair, complexion, and eyes. This is startling. Such physical attributes were very different to those of the Queen of Tragedy herself, and quite opposed to what we should associate with tlie being designated by Dr. Johnson, in unvarnished terms, as "an ogress."

Mrs. C. Kean has proved herself the legitimate successor of Mrs. Siddons, in Lady Macbeth, as in Constance. Both performances are so true to the author's 
meaning, while so distinct from each other, that it is impossible to say which is best. The scenes of "Macbeth" would fall flat, nay, they would almost be unintelligible, without the support of a lady quite up to the mark of the talent required for her husband. When Madame Ristori was here, her Lady Macbeth, not much run after by the public, found inordinate favour with more than one professed critic. We bow to the gallantry which eulogised a handsome woman, a foreigner, and an accomplished artist; but to compare her Lady Macbeth to that of our own representative was as unnecessary as it was absurd. The superiority of the latter is glaringly manifested throughout, and preeminently in the banquet and sleeping scenes. The sufferings of that midnight walk, as represented by Mrs. C. Kean, almost atones for the blood with which she has deluged the play. Madame Ristori, it must be admitted, had the disadvantage of a Macbeth, as comic as Robson in the burlesque, but without an atom of his peculiar and extraordinary power.

On Saturday the 19th of November, the performances at the Princess's were varied by the production of "Much Ado about Nothing;" perhaps the most complete comedy ever dashed off by the rich fecundity of Shakespeare's genius. It is a coruscation of brilliancy, teeming with genuine wit, effective situations, and contrasted characters, forming a most delightful relief to the two stately tragedics with which it was flanked on either side. The play comprises a double plot, most ingeniously contrived and disentangled. Yet some captions objectors find fault with the conspiracy against Hero, as clumsy and improbable. If such hypercriticism is to stand good, it will break down all that successive ages have considered excellent in dramatic composition; and if the imaginative attributes of the drama are to be judged by, and reduced 
to matter of fact rules, we may banish at once, fancy, invention, and poetic licence. Bcsides which, daily experience impresses the conviction that the incidents of real life are often more inconsistent and improbable than the wildest fictions of romance.

But whatever may be the merits or defects of the episodial plot of "Much Ado about Nothing," the attention and interest of the spectators are almost exclusively engrossed by Benedick and Beatrice. They form the charm and cynosure of the play. We think of little else, from their first tilting match in the opening scene, until they are finally tricked into "a mountain of mutual affection." These lively combatants are the most exquisite of companions, delicious sweeteners of life's variegated feast, however a doubt may arise as to their being the most promising and happily matched of married couples. They are the pure and beautiful emanations of Shakespeare's creative mind. He first conceived and gave a miniature of them as the Biron and Rosaline of "Love's Labour's Lost." In the present comedy they are expanded into full portraits, and launched on a new sphere of action adopted by the great master for his immediate purpose. It is seldom that Shakespeare takes the trouble to invent his incidents. He usually draws from history or earlier fiction, amplifying and adorning at pleasure the restricted and not unfrequently commonplace materials supplied from current sources. The plot on the two self-styled marriage haters is most happily conceived; and as they are as similar in disposition as the difference of sex allows, repeating the same mode of deception on each is natural and consistent.

Mr. and Mrs. C. Kean were seen to great advantage as Benedick and Beatrice. The parts are well selected to afford sucl opportunities of playing up to each other, which associated feelings alone understand, and nothing 
but constant practice can exercise with the high finish of art. Benedick has ever been a favourite with audience and actors. Garrick, as we are told in his memoirs, absolutely revelled in his delineation of this gallant humorist. Henderson, who followed him, was thought by good judges to tread closely on the heels of his predecessor, although when he rehearsed this very part before the great manager, the latter discouraged him by saying, "Young man, you must get the worsted out of your throat before you ean expect to be an actor." Lewis had all the breadth and vivacity required, but he wanted aplomb, and marred the general effect by being somewhat flippant and fidgetty. Elliston, in his best days, was considered an excellent representative, and Charles Kemble's impersonation commanded universal praise. Mr. C. Kean's may fairly be included in the same category. When witnessing his soldierlike and graceful bearing, with the easy, unlaboured humour by which, with a single glance of the eye, a turn of expression in the features, or a change of intonation in the voice, he excites the audience to a spontaneous burst of laughter or applause, we can searcely identify the same individual whom, a night or two before, we have listened to and looked upon as the sanguinary Macbeth, the gloomy $J o h n$, the crafty tyrant Louis, or the frenzied octogenarian Lear. The versatile powers of the actor, as thus displayed, are truly marvellous. In personal, as in mental attributes, nothing can be more contrasted than these solemn, soul-appalling protagonists, and the accomplished soldier, scholar, and man of fashion, the joyous Benedick, the type of all that we conceive of elegant and fascinating in what Lord Byron aptly termed "gentleman's comedy." Mr. Kean's first step on the stage bespoke his full conception of the character. His early scenes gradually worked up the spectators and himself as his 
humour progressed. There was no occasional flag or pause, no sinking to rise again after a dull interval. It was all buoyancy and flashes of light, each following closely on the other with increasing brightness. We may select for especial praise, and as indexes to the subsequent scenes, the two celebrated soliloquies in the second act, in the garden, where the supposed love of Beatrice is conveyed to his astonished mind by his accidental and unseen presence at the planned conversation of his friends. We must add to these lis fervid exit with a determination to requite such unlooked for affection as it deserved. No acting, in the genuine vein of the comic muse, could exceed this, which produced unanimous applause. In the challenge to Claudio, Benedick loses for the moment all his constitutional light-heartedness. $\mathrm{He}$ is transferred into a deeply serious man, in one of the most painful of situations, peremptorily but reluctantly imposed on him by duty and love. Mr. C. Kean, in this finely discriminated passage of the part, is perfectly at home. He plays the scene with marked feeling and delicacy. Charles Young, in general a noble actor, quite mistook it. He preserved even here a comic expression which destroyed the effect, and would have thrown Shakespeare into a cold perspiration, could he have witnessed the strange perversion of his meaning in conscious presence.

Beatrice, in dramatic value, stands on a par with Benedick. She yields him no jot of precedence or superiority. Happy in the possession of an amiable, warmhearted temperament, and unaffected spirits, she returns him arrow for arrow in the combat of words. Her gaiety is artless, natural and unforced. The essence of her mind is wit, which, like Benedick, she directs against love and matrimony. But extremes often meet, and thus these jarring elements are brought to blend into 
harmonious and mutual subjection. Mrs. C. Kean thoroughly comprehends every nice shade and feature of this masterly. portrait. She presents it in all the glowing life that the author imagined, but without exaggeration or over-colouring. With all her elevated position in society, and its associations of manner and habit, her warm sympathies and cultivated tastes, some Shakespearean investigators, seeing through a small inicroscope, have discovered in Beatrice a tendency to selfwill, a strength of purpose, which augur inauspicously for her connubial life in prospectu, and may darken it with an occasional cloud. They affect to tremble for Benedick, " the married man," and turn their thoughts with some apprehension to the "predestinate scratched face" he so earnestly deprecates. We confess that we never could take this view, and Mrs. C. Kean has confirmed our opposite conviction to our infinite delight. Shrewish wives are not gifted with the good breeding and good temper of her Beatrice. We feel truly grateful to this accomplished mistress of her art for vindicating, by her accurate and refined perception, the true intent of Shakespeare; and for allowing no infusion of selfishness, no wayward humour to blemish or weaken the moral grace and beauty of one of his most captivating heroines.

Little was said in the bill, and less in the printed version of the play, of the new effects so lavishly introduced in the stage-arrangements and scenery, which lost nothing in comparison with the recent splendour of the "Merehant of Venice." The opening view, the harbour of Messina, was quite a pictorial gem. The gradual illumination of the lighthouse and various mansions, in almost every window, the moon slowly rising and throwing her silver light upon the deep blue waters of the Mediterranean, were managed with imposing reality. 
Then followed the masquerade, with its variegated lamps, bridge, gardens, and lake, seen through the arches of the palace. The general acting left nothing to be desired. Mr. F. Matthews added much to his reputation by his impersonation of Dogberry. He was quaint, original, and overflowing with stolid, good-humoured importance, reminding the audience of W. Farren in his best days. Mr. Meadows has long been identified with Verges; an unparalleled sketch of servile imbecility acquiring in his hands substantial prominence.

In our more important notice of the Shakespearean revival, we must not omit the mention of a new farce produced on Monday the 21st of November, called "Thirty-Three next Birthday," adapted from or founded on a French original, but arranged in its English dress by Mr. J. M. Morton. The substance of this amusing prelude may be compressed into a few words. Miss Havoc, a single lady, on the verge of thirty-three, is determined to get married, and thinking she can more readily obtain admirers as the young wife of an old gentleman, than as a somewhat mature spinster, persuades an easy-tempered, obliging uncle, Major Havoc, to assume the character of sposo, and accompany her in that guise to a Welch watering-place. There she speedily wins the hearts of two speculating swains, Mr. Benson and Mr. Cackleberry, one young, and the other middle-aged. After much equivoque and sundry explosions of passion, the lady accepts the elder lover, $M r$. Cackleberry, the solicitor, and so the piece concludes. The leading parts were extremely well acted by Miss Murray, Mr. Cooper, and Mr. F. Matthews. The latter, in particular, contributed much to the success.

The usual pantomime was produced at Christmas, but this year from the pen of Mr. Forester (Alfred Crowquill). It proved to be one of the best and most attrac- 
tive that had been produced for years. The subject was entirely invented by the author, the title being "'The King of the Castle; or, Harlequin Prince Diamond and the Princess Brighteyes." In the introduction, the elegance and interest of a fairy tale were combined with a fair proportion of broad burlesque, but without trenching on the more legitimate buffooneries of the Clovon and Pantaloon. The surviving elders of the old school, the contemporaries of Grimaldi, father and son, consider the genius of pantomime as dead, buried, and forgotten; not considering that taste in this, as in other more important matters, has undergone a complete revolution since their school-boy days, when they revelled in the glories of "Mother Goose and the Golden Egg," and that what pleased fifty years ago might be looked upon as coarse, if not unintelligible, by the living generation. It certainly requires more classical knowledge and a higher endowment of intellectual faculty to write a firstrate tragedy or comedy than to compound a good opening to a pantomime; nevertheless, the latter is a task of great ingenuity, seeing how thoroughly the materials have been ransacked and exhausted. A new idea descends like a ray of light, and an original trick or transformation is as rare as a coin of Otho or Pescennius Niger.

The comic scenes of "The King of the Castle" invented and arranged by Mr. Ellis, stage-manager, and Mr. Cormack, ballet-master, contained some good hits at the passing follies of the day, in which crinoline came in for a conspicuous share. Here again the living pantomimist labours under difficulties unknown to his grandfather. There are few salient eccentricities in modern manners to afford subject for illustration or caricature. The world may be wiser than it was, but it has grown more selfish and calculating, and people have 
no longer time to indulge in absurdities, which lead to no increase of worldly store. Formerly, no one could sit in a coffee-room for half an hour, or walk up St. James's-Street without meeting character in some decided shape, either developed by dress, bearing, or conversation. Now, we are all alike; ever in a hurry, on the one ligh road of utilitarianism, thinking, travelling and sleeping at railway speed. All this may tend to make people rich, and sharpen their wordly intellects, but it furnishes no materials for a comic pantomime. Let us, therefore, not criticise too closely, but be thankful to those who still find means to supply us with a fev hearty laughs from the old familiar source.

During the run of the pantomime, the old comedy of the "Jealous Wife" was revived. This, with "Louis the Eleventh," and the "Corsican Brothers," alternated the performances, with the Shakespearean plays of "The Merchant of Venice," "A Midsummer Night's Dream," "Macbeth," "Much Ado about Nothing," and "Hamlet;" forming a rich variety, which produced unceasing attraction. "Hamlet" was performed eleven times to crowded houses. "Age cannot witler" this noble play, "nor" custom stale its infinite variety." Let the principal character be well acted, and the attraction never fails. To master the representation of the Danish prince requires the study of a life. John Kemble, speaking from long experience, said so, when on the eve of retireinent.

The Germans assume, and many English admirers of German criticism and literature liave admited the claim, that they possess a more correct and thorough appreciation of Shakespeare than we ourselves acknowledge or feel. In support of this assertion they appeal to the elaborate disquisitions on Hanlet in "Wilhelm 
Meister's Apprenticeship," as containing the truest analysis of the play, and the principal character, which has yet been given to the world. We rebel utterly against this dictum. Shakespeare was neither a metaphysician nor a transcendentalist.* He was simply an inspired pupil of nature, who wrote as he thought and felt, with unstrained, obvious meanings, and drew his pictures from men as they are, and not from such ideal exaggerations as dogmatic, and frequently miscalled philosophy creates in a morbid mood, and tries to render intelligible by ingenious sophistries. An English auditor in the theatre, and a student in the closet, look upon "Hamlet" less as a poetical illusion than as an actual acquaintance and associate-a familiar being in actual existence. They understand him without perplexing commentary, and when they see him moving before them in living identity, under the person and attributes of a great actor and a faithful reflector of the poet's genius, such as Mr. Charles Kean, they hail the illustration with delight, and a perfect comprehension of what is intended to be conveyed to their understandings, more intense and distinct than any impression they could derive from poring over the labored essays of Göethe and Ulrici.

On Friday, January 28 th, 1859 , another veteran actor, Charles Farley, the father of the stage, departed this life. Having attained the ripe age of eighty-seven, he outlived all his theatrical contemporaries. Entering the theatrical world in his tenth year, he saw the rise and progress of all the Kembles, Cooke, Young, Edniund Kean,

* No-nor a materialist, nor a freethinker, nor a denier of revelation and a disheliever in providence and futurity; although Mr. W. J. Birch, A.II. of New Inn Hall, Oxon, has laboured hard to prove him all these, in a work published in 1S47, entitled "An Incuiry into the Philosophy and Religion of Shakespere." This is not the place to show the fallacy of his arguments, which lie broadly open to refutation.

VOL. II. 
Macready, and Charles Kean. His peculiar talent lay in the superintendance of pantomimes and melo-dramas. He was also the author of several pieces of the latter class. Both in his public and private capacity, he was much esteemed, and his long dramatic experience sup. plied his conversation with an endless fund of anecdotes. 


\section{CHAPTER XVI.}

PRESENTATION OF A TESTMONIAL TO MR. KFAN FROM THE COMMTTEE OF THE DRAMATIC COLLEGE-MR. AND MRS. C. KEAN'S ANNUAL BENEFIT IN 1859-LAST SHAKESPEAREAN REVIVAL-KING HENRY THE FIFTHORIGINAL EFFECTS-STORMING OF HARFLEUR-BATTLE OF AGINCOURTINTRODUCED EPISODE OF ACTION TAKEN FROM HISTORICAL ACTHORITIES-MRS. C. KEAN AS THE CHORUS; MIR. C. KEAN AS KING HENRY - CNPRECEDENTED ATtRaCtion OF THE PLAX-DELINEATION OF NATIONAL CHARACTER-FLUELLEN IDENTIFIED WITH DAVID GAMCORIESPONDEXCE-NEW COMEDIETTA, IF THE CAP FITS.-HENRY THE EIGHTH-BANQUET AND TESTIMONIAL PROPOSED BY THE ETONIANS NOTICES IN THE PAPERS-CONGRATULATORY LETTERS.

Ox Monday, February the 21st, a deputation, consisting of Sir William De Bathe, Bart.; Sir George Armytage, Bart.; Mr. Benjamin Webster, the chairman of the provisional committee of the Dramatic College; and Messrs. Creswick, Jerwood, and Cullenford, waited upon Mr. Charles Kean, at his private residence, in Upper Hyde Park Street, for the purpose of presenting him with the following testimonial :- "In acknowledgment of the great obligation of the Royal Dramatic College, to Charles Kean, Esq., F.S.A., for services rendered by him as chairman of the public meeting held in the Royal Princess's Theatre, on the 21st of July, 1858; for his liberality in undertaking to provide one of the dwellings for the reeption of aged and infirm actors and actresses ; for his admirable zeal in otherwise promoting the interests of the College; and to record the personal regard and sincere wishes of the Provisional Committee for his future welfare." This testimonial was elegantly inseribed upon vellum by Mr. Moring, of 
Holborn. Mr. Webster, in presenting it, spoke in high praise of the great zeal with which Mr. Kean had exerted himself on behalf of the college, and which the latter gentleman responded to in suitable terms.

On Monday, the 28th of March, Mr. and Mrs. C. Kean announced their annual benefit and last Shakespearean revival, the play selected being "Henry the Fifth." The usual fly-leaf affixed to the bills concluded with the following passage :-

"As the term of my management is now drawing to a close, I may, perhaps, be permitted, in a few words, to express my thanks for the support and encouragement I have received. While endeavouring, to the best of my ability and judgment, to uphold the interests of the drama in its most exalted form, I may conscientiously assert, that I have been animated by no selfish or commercial spirit. An enthusiast in the art to which my life has been devoted, I have always entertained a deeply rooted conviction, that the plan I have pursued for many seasons, might, in due time, under fostering: care, render the stage productive of much benefit to society at large. Impressed with a belief that the genius of Shakespeare soars above all rivalry; that he is the most marvellous writer the world has ever known; and that his works contain stores of wisdom, intellectual and moral, I cannot but hope that one who has toiled for so many years, in admiring sincerity, to spread abroad amongst the multitude these invaluable gems, may, at least, be considered as an honest labourer, adding his mite to the great cause of civilization and educational progress.

"After nine years of unremitting exertions as actor" and director, the constant strain of mind and body warns me to retreat from a combined duty which I find 
beyond my strength, and in the exercise of which neither zeal nor devotion, nor consequent success, can continue to beguile me into a belief that the end will compensate for the many attendant troubles and anxieties. It would have been impossible, on my part, to gratify my wishes in the illustration of Shakespeare, had not my previous career as an actor placed me in a position of comparative independence with regard to speculative disappointment. Wonderful as have been the yearly receipts, yet the vast sums expended-sums, I have every reason to believe, not to be paralleled in any theatre of the same capability throughout the world-make it advisable that I should now retire from the self-imposed responsibility of management, involving such a perilous outlay; and the more especially, as a building so restricted in size as the Princess's, renders any adequate returns utterly hopeless.

"My earnest aim has been to promote the well-being of my profession; and if, in any degree, I have attained so desirable an object, I trust I may not be deemed presumptuous in cherishing the belief, that my arduous struggle has won for me the honourable reward ofpublic approval."

No play could have been more appropriately timed for the particular occasion on which it was brought forward, than "Henry the Fifth,"-the only historical drama in the English series, excepting the second part of "Henry the Fourth," as yet unrepresented at the Princess's. The great grandson of Edward the Third was the most popular monarch that ever swayed the sceptre of England in by-gone days. His short reign may be looked back on with unmingled satisfaction, as an epoch of glory, accompanied only by the one regret that he should have been so prematurely cut off. How 
differently would English history have been written, had Henry, with his chief princes and nobles been slain, or made captive, as the chances were twenty to one against them that they would, on the memorable field of Agincourt. And again, had he not been suddenly removed in the full bloom of his fame and manliood, leaving the throne to an infant heir, in all human probability, the devastating quarrels of York and Lancaster would never have filled our annals with their sanguinary details. The records of that warlike age, the campaigns in France, make the hearts of Englishmen swell; and are well recalled at a time when a restless neighbour, armed to the teeth, is evidently in search of an antagonist, anywhere, on any pretext; and when constant alarms warn us to be on our guard, and prepared in case of unprovoked attack. The remembrance of past heroism is a wholesome spur to national pride, a sound guarantee for the future.

"Henry the Fifth" contains no female part of importance. The play is full of bustle and animation, of variety and excitement; but, the interest turns on war and politics, almost to the entire exclusion of domestic feelings and relations. Here was an objection at once, but for the happy thought of individualising the Chorus as the Muse of History, and of thus securing the exalted talent of Mrs. C. Kean, for the delivery of some of the most impressive poetry of description that Shakespeare ever penned. In other plays, the "Winter's Tale," and "Pericles," for instances, Shakespeare has specifically named Time, and the old poet Gower, as the representatives of this explanatory introduction to each act. In Garrick's day, for some unknown reason, he declined the part of "King Harry," but considered the Chorus worthy of his elocutionary powers. He spoke the speeches as Mr. Garrick, arrayed in the costume of 
the day, a full dress court suit, with powdered bag wig, ruffles and sword. When "Henry the Fifth "was last revived at Covent Garden, in 1839, we had the symbolical "Chorus," under the guise of an aged man, with the traditionary appurtenances. By the present substitution, as gracefully described in the preface, " an opportunity is afforded to Mrs. C. Kean, which the subject does not otherwise supply, of appearing in this, the concluding revival of her husband's management." In the early editions of the play, this Chorus is simply called a prologue; and a prologue in effect it is, describing and connecting the quick succession of events, the rapid changes of locality; and elucidating passages which might otherwise appear confused or incongruous. But, chorus, or prologue, or interpreter, or by whatever name the mystical creation is to be designated, never until now has its importance been so thoroughly felt and understood. In the person of Mrs. C. Kean it forms the presiding charm, the key-note, if we may use the term, of the entire play. Her appearance, action, and utterance, present a combined picture of classic grace, and poetical inspiration. She might have stood to any sculptor, ancient or modern, for a statue of the Clio she so magnificently impersonates.

It was expected, and with good reason, that $\mathrm{Mr}$. Kean would light on a play (as yet unrepresented) for his last great effort, that might enable him not only to concentrate all the resources of his judgment and experience, but affording at the same time a field for new effects and untried cxperiments. He har? given festivals, masquerades, processions, and dances, ancient and modern; mythological tableanx and supernatural appearances, unimagined and unattempted by the most gifted of his predecessors. He had also dealt largely with the "pomp and circumstance of 
war," in "Macbeth," "King John," and "Richard the Third." "Henry the Fifth," in addition to a great conflict crowned by a splendid victory, includes a siege, and the storming of a beleaguered fortress. Mr. Kean seized the novelty with the strong grasp of an original mind, and transferred to his small stage a representation of the most terrible of military feats in a manner that no description can even faintly convey an idea of, and which required to be seen again and again before all its wonders cculd be understood or appreciated. The assault on Harfleur, which opens the third act; the desperate resistance of the French garrison; the close conflict on the ramparts; the practice of the rude artillery of the day, with the advance of other besieging engines; and the final entry of the victorious assailants through the breach,--formed altogether the most marvellous realization of war, in its deadliest phase, that imitative art has ever attempted. The marvel is increased by the smallness of the space within which such numbers of men and so much complicated machinery are marshalled, together with the organization of the entire scene. Every supernumerary acted with the intelligence of a trained artist, and every movement appeared as natural as if dictated to each separate individual by the impulse of the moment. Making due allowance for the scale of action, the difference of weapons, equipments, and the absence of defensive armour,-the storming of the breach at Harfleur, as transferred to the boards of the Princess's Theatre, vividly embodied the carrying of the Malakoff, as we have heard it described, and figure it in our imagination, from pictures and recitals.

From Harfleur, the action of the play carries us rapidly on to Agincourt, the Waterloo of the middle ages; a field which.decided for a time the long rivalry between France and England, and entirely to the 
advantage of the latter. Shakespeare in his glowing scenes has followed the incidents of this great campaign as he found them described in the Chronicles of Holinshed, adorning them with the magic of his own genius. Mr. C. Kean has invested Shakespeare with the living identity he intended to represent, and may have dreamed of as his thoughts looked onwards to futurity, but which in the infancy of stage resources, and with an uneducated public, he never could have hoped to witness in his own days.

'The third and fourth acts comprise the most interesting portion of the play. Again our wonder is called forth by the skill with which the English army is manouvred and brought into battle, and by the extent of the masses employed. The march from their own ground of encampment to the attack on the French host - the firm tread and demeanour of men resolved to conquer or die; roused from momentary despondency, and almost maddened by the inspiring address of their king and leader, so gallautly delivered by Mr. Kean;-the general excitement and stirring reality, so unlike stage deception, and so closely embodying truth;-all these animated delusions bewilder the faculties of sight and learing, and enforce on the spectators a conviction that they are looking on the very men who fought and won that glorious field. We are carried back to the actual time and place, until we feel as if really participating in, and present at the events thus surprisingly reproduced in the theatric microcosm, so faithfully reflecting the world of four hundred and forty years anterior to that of the day in which we live and move.

When King Henry returned to his own capital erowned with the laurels of Agincourt, the citizens of London prepared for him a reception which, in splendour and imposing pomp, cast into shadow the Pagan 
triumphs of the Roman Cæsars, while it far exceeded them in heart-felt gratulation. Ever beloved by his people, Henry was now their idol. Shakespeare speaks of this pageant through the mouth of the Chorus, but, of necessity passes over the scene. Mr. Kean has introduced it in an episode of action, carefully following the account of an eye-witness, whose MS. has been preserved, and is referred to in the preface to the printed edition of the play as now acted. The locality is supposed to be old London Bridge, from the Surrey side of the river. The success of a somewhat similar episode in "Richard the Second," undoubtedly suggested the idea, but the mode in which the later introduction is carried out, is totally different, and far more elaborate, as well as superior in the interest of the situation and the character of the incidents. In "Richard the Second," we had the entry of a successful usurper, clouded by the presence of his deposed and lawful monarch. In "Henry the Fifth" we have the triumph of a popular sovereign, unmingled with painful associations. The arrangement of this scene may be quoted as another wonderful instance of the fertility of Mr. Kean's mind, and of the unremitting research he bestows on the immediate subject of his illustration. The action ends here, with the exception of the betrothal of King Henry to the Princess Katharine, in the cathedral of Troyes, which winds up the whole in graceful repose. The play occupied nearly four hours. No prelude or afterpiece was acted with it at first, but the attention of the audience never wearied for a moment; they were manifestly so absorbed in the one subject, that the introduction of any other would have been an interruption and not a relief.

'There are no fewer than thirty-seven speaking characters in "Henry the Fifth," but they are all of 
minor importance, the acting strength being almost exclusively concentrated in the King, who is seldom absent from the scene. It is not easy to decide as to what section of the drama this amiable and popular hero belongs. He has a vein of comic humour which reminds us of the constitutional pleasantry of Prince Hal, restrained and chastened by the dignity and responsibility of his royal duties. The part does not embrace the madness of Lear, the conscience-stricken agony of Macbeth, the frenzied jealousy of Othello, or the profoundly meditative philosophy of Hamlet; but it requires, nevertheless, an actor of great and varied power to supply an adequate representative. All the great tragedians of the day, from John Kemble to Charles Kean, have included it in their cast, although with very unequal success. It requires the versatility denied to some, but in which our present representative so eminently excels. The pith and martial bearing of the character lie principally in the third and fourth acts. The reflections on sovereign power, and its hard conditions, suggested to Henry by his midnight walk through the camp on the eve of Agincourt, were delivered by Mr. Kean with deeply impressive feeling. This soliloquy, and his supplication to the "God of battles," are contrasted in a masterly manner with the fiery, unstudied energy of his harangue before he leads his army to the charge. The thorough comprehension of the different points in Shakespeare's delineation of his own especial hero, were also marked with great care by Mr. Kean in the frankness of his manner when conversing with Fluellen; in his dialogne with the soldiers, Williams and Bates; and in the military freedom and gallantry of his courtship in the last scene. Such a dramatic treat as Mr. Kean's revived "Henry the Fifth," has never before been offered to the public, and 
will stand alone in all future histories of the English stage. We may say, without exaggeration, that all London flocked to see it, and all England crowded to London for the same purpose. When the curtain fell on the last right of its performance, every one felt that it would never rise again on a Shakespearean exlibition of similar excellence. The entire outlay exceeded 3000l. The bill for the rehearsals of the supernumeraries alone, amounted to $160 l$., including their refreshments. $\mathrm{Mr}$. Kean was so well satisfied with their attention to his instructions, and the intelligence they exhibited in catching the spirit of the scenes when explained to them, that he doubled the pay of all on the first night, and distributed above one hundred pounds more in specific gratuities.

In the first act of "Henry the Fifth," Shakespeare gives a farewell reminiscence of Falstaff, in the description of his death, by Mrs. Quickly. Of his followers, Pistol retains some degree of prominence, but Nym and Bardolph are mere cyphers, and the latter is hanged for sacrilege. A subject so popular as "Henry the Fifth," has occupied pens of far inferior inspiration to that of Shakespeare. Neither the date nor the author of the anonymous drama which preceded his, have been ascertained. A reprint of it is to be found in a collection of six plays, edited by Nichols, and published in 1779. The two volumes occasionally occur in a sale catalogue, and are curious to the Shakespearean collector. In 1664, another "Henry the Fifth," by the Earl of Orrerey, was acted at the Duke of York's Theatre in Lincoln's-Inn-Fields. Downes (Roscius Anglicanus) says it was excellently performed, and acted ten days in succession. It is written in rhyme, and has not the least rescmblance to Shakespeare's, except in the historical portion. Owen Tudor and the King are 
represented as sworn friends, and are both in love with the Princess Katharine. The love scenes are absurd to the last degree. The characters were most splendidly attired, particularly King Henry, Owen Tudor, and the Duke of Burgundy, who wore the coronation suits of King Charles II., the Duke of York, and the Earl of Oxford. The actors who performed them were Harris, Betterton, and Snith. It was said to have been in the part of Owen Tudor that Betterton laid the foundation of the great celebrity he afterwards acquired.

In 1723, Aaron Hill produced an alteration of "Henry the Fifth," which was acted at Drury Lane for four nights. Many of the incidents, and much of the language, are borrowed from Shakespeare; but a second plot is introduced by the addition of a new female character, Harriet, as she is called, a niece of Lord Scroope, who has been formerly seduced by the King. She appears in men's clothes throughout, and is made the means of discovering the conspiracy against Henry. Mr. Hill, with a liberality or enthusiasm little known or practised by authors of more recent days, presented the managers of the theatre with sets of scenes for this drama, which cost him $200 l$.

Shakespeare, in the comic relief of his play, has aimed at national dialects as understood in his age. He has given us a Welshman, Fluellen; an Irishman, Macmorris; a Scotchman, Jamy; and a Frenchman, Monsieur le Fer. With the exception of the former they have always been omitted, and we may say without detriment, in the acting versions. Fluellen is well conceived, and an amusing introduction. In Jones's "History of Brecknockshire," we find the following passage, tending to connect this imaginary personage with the historical David Gam, who so gallantly sacrificed himself at Agincourt to save his king. 
"In consequence of an affray in the High Street of Brecknock, in which David (Gam) unfortunately killed his kinsman, Ritsiart fawr o'r Slwch, he was compelled to fly into England; and, to avoid a threatened prosecution for the murder, attached himself to the Lancastrian party, to whose interest he ever after most faithfully adhered. There can be little doubt but that Shakespeare in his burlesque character of Fluellen, intended David Gam; though for obvious reasons, as his descendants were then well known and respected in the English court, he chose to disguise the name. I have called Fluellen a burlesque character, because his 'pribbles and prabbles' sound ludicrously to an English as well as to a Welsh ear. Yet, after all, Llewellyn is a brave soldier, and an honest fellow; he is admitted into a considerable degree of intimacy with the king, and stands high in his good opinion, which is strong presumptive proof, notwithstanding Shakespeare, the better to conceal his object, describes the death of Sir David Gam, yet that he intended David Llewellyn by this portrait of the testy Welchman; for there was no other person of that country in the English army who could have been supposed to have been on such terms of familiarity with the king. It must also be observed that Llewellyn was the name by which he was known in the army, and not Gam, or Squinting, by which epithet, though it was afterwards assumed by his family, he would probably have knocked down any man who dared to address him. By his behaviour on this memorable day, he, in some measure, made amends for a life of violence and rapine, and raised his posterity to riches and respect. But, alas! how weak, how idle is family pride, how unstable worldly wealth! At different periods, between the years 1550 , and 1700 , I have found these descendants of this hero of Agincourt (who 
lived like a wolf and died like a lion), in possession of every acre of ground in the county of Brecon; at the commencement of the eighteenth century, I find one of them the common bellman of the town of Brecknock; and before the conclusion, two others supported by the inhabitants of the parish where they resided, and even the name of Games, in the legitimate line, extinct."

A small section of the clergy still continue, from time to time, on the old ground of exploded fallacies, the worn-out topic of abuse, to preach against the stage. As usual, the advocates of the theatre reply, and a hot controversy ensues, in which temper and argument are frequently lost together, with more of scandal than profit to either side. A more conclusive answer may be found in the number of divines, who, throughout Mr. Kean's management, might be seen, at all the Shakespearean revivals, in the stalls and boxes of the Princess's Theatre. During the run of "Henry the Fifth," the following letter was addressed to him by the incumbent of a rectory in the country:-

\section{" MY DEAR SIR,}

“ May 3, 1859.

"Had not a friend unexpectedly come to see me last evening, I should have written to you, apologizing for the apparently rude way in which I sent my card to you behind the scenes on Friday, after the performance had commenced. Your kind letter received this morning, has quite set my mind at rest as to the manner in which you received it. My coming to town at all was a sudden freak, carricd out on the spur of the moment. I wished to give my boys, who were with me, an Easter holiday. I was particularly anxious to see "Henry the Fifth;" and on Friday morning there was a sudden calm after some rough 
winds, which looked tempting enough for a sea trip. Hence it was that we only arrived in London in time to get to the Princess's at seven o'clock, and found all the stalls engaged, and seemingly, the entire house crammed. Rather than go so far on a fool's errand, after raising the boys' expectations so high, I scratched a hasty message to yourself, to see if you could help me out of the difficulty, and immediately after this, the boxkeeper found me a couple of seats, into which we all three managed to pack ourselves, and sat very comfortably indeed throughout. I was far more than gratified; I would not have missed the representation for anything; I was delighted-carried away. Since I returned home, I have read through "Henry Fifth" again, and wondered that I had not seen so many beauties in it before. For such a lesson in elocution, $I$ and the five or six other clergymen I saw around me, ought to be properly grateful to you. One of the persons, by the bye, was my old tutor at Exeter College, whom I had not seen since 1845. He is now, I believe, a very energetic "via media" man, with a strong bias to "Evangelicalism." He seemed, however, to be thoroughly rapt by the splendour of the ecclesiastical ceremonial you set before us. So modestly chaste, and so simply grand in outward pomp and in exquisite music, that I do not believe even Lord himself could have been offended at it. It was, in fact, too real to offend the most delicate religious susceptibility. There was nothing sham to strike either ear or eye; and so the touching nature of the various incidents connected with Henry's invasion of France appealed straight to our hearts. I can assure you that our attention and interest remained in the same unflagged condition of excitement into which they had been worked by the opening scenes. ? 
"I should much like to know when the period of your management closes, because a large party of us intend to come up on purpose; and yet, if possible, we want to put off our coming until July. With my kind regards and compliments to Mrs. Kean, in which all my family will gladly join, when I apprise them of my having written, and to yourself also,

$$
\begin{aligned}
& \text { "I am, my dear Sir, } \\
& \text { "Very sincerely yours, }
\end{aligned}
$$

The attraction of "Henry the Fifth" superseded the necessity of an Easter novelty; but on Whit Monday, the play, which until then had stood alone in the bills, was followed by a new Comedietta, in one act, written by Messrs. Yates and Harrington. It was called "If the Cap Fits," and met with a most favourable reception, being repeated for nearly fifty nights. We know not whether this amusing trifle is of French origin, or entirely original. The dialogue is smartly written, with point and humour, showing that the authors are well practised in one leading essential of dramatic composition. The characters are ingeniously contrasted, and were impersonated with due spirit by Miss Murray, Miss Bufton, Mr. W. Lacy, Mr. Everett, and Mr. F. Matthews.

On Saturday, July the 9th, "Henry the Fifth" was acted for the eighty-fourth time, and finally withdrawn after that evening.* During the last nights the houses were crowded to excess. The aggregate receipts went far beyond those of its most successful Shakespearean predecessors. The run of the play did not terminate because its popularity was on the wane, but from a

- At Covent Garden, in 1839, under Mr. Macready's management, Henry the Fifth was acted twenty-one nights ; not consecutively, but on alternative evenings with Richelieu, the Stranger, As You like it, the Winter's Tale, and the Lady of Lyons.

VOL. II.

A $A$ 
desire on Mr. Kean's part to gratify his patrons with variety, as the concluding weeks of his management approached. "Henry the Eighth," which had been repeatedly asked for, was produced on Monday, July the 11th. A lapse of four years had occasioned no changes of importance in the distribution of the principal characters. All the great scenic effects were restored with their former splendour and historical accuracy. The acting of Mr. and Mrs. C. Kean, as Cardinal Wolsey and the Queen, presented, if possible, more finished exhibitions of two of Shakespeare's most elaborate portraits, than those with which they had delighted one hundred successive audiences in 1855. Our details in a preceding chapter render repetition here unnecessary.

The season now approached its termination; but, before the last night was announced, Mr. Kean received one of the most flattering tributes ever bestowed by public opinion on distinguished ability and services. His old Etonian companions came forward, spontaneously, to proclaim to the world that the first actor of the day had been educated amongst them, and was one of themselves. Through the following graceful announcement, they invited the people of England to join them in a common tribute to one whose private and professional life reflected honour on the seminary to which -they all belonged, and had been so perseveringly devoted to the elevation of a noble art.

"Proposed Public Banquet and Tespimonial to Charles Kean, F.S.A., at St. James's Hall, on Wednesday, July 20, 1859.

The EARL OF CARLisle in the Chair.

"A number of noblemen and gentlenien, educated at Eton, nearly all of them contemporary with Mr. Charles Kean, have formed themselves into a Committee for the 
purpose of inviting their old schoolfellow to a banquet, on the occasion of his retiring from the management of the Princess's 'Theatre, and of presenting him with a testimonial to mark their sense of his distinguished talent.

"The Committee, further considering that the right of acknowledging $\mathrm{Mr}$. Kean's services belongs to the nation at large, are anxious that the public should unite with them in testifying their admiration for one who has so long and so snccessfully laboured to provide for their intellectual enjoyment, and who has done so much towards upholding the dignity and high character of the national stage.

"All communications to be addressed to the Hon. Secretary, Thomas Henry 'Taunton, Esq., at Mr. Sams' Royal Library, 1, St. James's Street.

\section{COMUITTEE.}

His Grace the Duke of Neweastle. Right IIon. W: E. Gladstone, MI.P. His Grace the Duke of Rutland.

Mast Hon. the Marquis of Lon. donderry.

Right Hon. the Earl of Carlisle. Right Hon. the Earl of Eglintoun. Right Ilon. the Earl of Craven. Right IIon. the Earl of Dunraven. Right IIon. the Earl of Norbury. Right IIon. the Earl of Sandwich. Right IIon. the Earl of Selkirk. Right IIon. the Earl of Chesterfield. Right Ifon. the Viscount Pollington. Right Hon. theViscount Exmouth. Right Hon. the Viscount Chelsea. Rt. I Ion.the Lord J.Manners, II.P. The Lord Macelonald.

The Lord Ernest Bruce, II.P.

The Lord Lindsay.

The Lind John Scott.

Col. the IIon. Angustus Liddell.

Col. the IIon..Js. Lindsay, II.P.

Col. De Bathe.

Major Blake.

The Hon. William Cowper, II.P.

Right Hon. Spencer Walpole, M.P.

Gen, Sir J. Burgoyne, Bart. G.C.B.

SirWalter:Iinto Farquhar,1Bt.II.P.

Sir Frerlerick Rogers, Bart.

Col. Clifford, MI. P.

C. J. Selwyn, Esq. MI.P.

Sir John Duntze, Bart.

Sir Francis Hastings Doyle, Bart.

Mr. Serjeant Kinglake, MI. P.

William Vansittart, Esq. MI.P.

Thomas E.MIoss, Esqu of Liverpool.

Thomas Phinn, Esq. Q. C.

Walker Skirrow, Jun. Esq.

William Platt, Esq.

W. C. Long, Esq.

P. L. Powys, Ess. M.P.

Lewis Lloyd, Esc.

Charles Guding, Esq.

Charles Edward Jolnnston, Esq.

Rer. R. Lewis Browne.

James Robert Hope Scott, Esq. D.C.L. and Q.C.

Lient.-Col. .I. Bruce.

T. H. Taunton, Esq. Hon. Sec. 
These advertisements had no sooner appeared, than many of the leading journals teemed with approving paragraphs, indicating the general interest excited by the subject. We select some passages from an article in a paper of extensive circulation, and much weight as a critical authority,* which condenses the chief points in a tone of clear reasoning and just compliment.

"To Mr. Charles Kean belongs the singular merit of distinguishing himself as the enthusiastic supporter of a sinking cause, and of delaying the final doom of the drama by his own individual force. From the aspect of the theatrical horizon we have no right to augur that any successor will arise to continue his work. On the contrary, we are assured that the next director of the Princess's Theatre will devote it to plays of the Porte Saint Martin school; and we cannot point to any other establishment in central London, which any living manager would dream of consecrating unreservedly to the manes of Shakespeare.

"Looking at the struggles of Mr. Kean,--at the labour of mind and body, for which no treasury could compensate, - we are inclined to compare him to those patriots of the latter days of Greek independence, whose names, less familiar than others who flourished in the days of Marathon and Thermopyle, come down to us surrounded by a tragic halo, and claim an especial respect from the very circumstance that they could only procrastinate, and could not prevent, the ruin of their country-the heroes of the Achæan League. David Garrick, when he revived a love of Shakespeare, had the pleasure of awakening a new sensation; and the Kcmbles and the elder Kean maintained the tragic drama while its attractive powers were at their height; but in Mr. Charles Kean we have the aspect of a zealot

* See the "Saturday Review," of June 18th, 185! 
contending against the tide of fashion,-fighting against the deadliest of adversaries, namely, weary indifference, -availing himself of expedient after expedient to carry ont the grand purpose of his life, without even the hearty encouragement of those who ought to have sympathized with his honest and well-directed endeavours. To force the sight-hunters into Shakespearean worship, he brought spectacle to a perfection little short of miraculous; but by this very method he offended a number of literary dilletanti, who, with monstrous assurance, and in defiance of all the teachings of experience, tried to make out a case in favour of shabby scenery. In vain did Mr. Kean explain, by an address in his play-bills, that his scenery and dresses were replete with historical instruction. The most miserable scribblers of burlesque thought it comic to turn the addresses themselves into ridicule, and were rewarded by the laughter of many who ought to have known better. But the great artist gave the best possible answer to his vituperators. $\mathrm{He}$ did not rub a particle of gold from his scenes, or dismiss a man from his band of supernumeraries, when they could be of service; but he relied more and more on his genius as an actor; and the toils of one entire season were expended to prove that, notwithstanding all the cant about smothering Shakespeare with finery, nobody was more decply impressed with the necessity of subordinating accessories to principals than the great actor himself. The characters which he successively played at the commencement of the present (his 'firrewell') season, one after the other, imbued the public with the conviction that a tragedian, unrivalled beyond the thought of competition, was about to leave them.

"And by whom has Mr. Kean been really supported throughout his honourable but toilsome career? Not by any class or clique; not by the aristocracy; not by 
the cultivators of light literature; not by a fashionable coterie: but by that substantial, undefinable public that takes in all these, but yet is influeneed by none; that public of which no one can diseover individual representatives; which expresses itself mass-wise, and which, deaf to the voice of intrigue and party criticism, is quick to appreeiate the deserts of those who really work well for its edification or amusement. In the eyes of the public, Mr. Kean has ever been the great actor; the publie have aeknowledged the beauty and historic worth of his decorations. It is only at the end of his career that his sehoolfellows, the Etonians, make their appearanee. They find him famous, and they honour the independent exertions by which the fame has been aequired."

During the interval that elapsed between the announeement and celebration of the festival, Mr. Kean reeeived a host of congratulatory letters from personal friends and professional admirers, many of whom were total strangers. Amongst the latter communications, few were more gratifying than the one we here subjoin, to which a double interest is attached, arising from the feelings avowed, and the position of the writer as a member of the clerical profession.

"MY DEAR SIR,-

"June 29.

"I once took the liberty, I fear a very unauthorized one, of writing to you; and I got so pleasant an answer, that $I$ venture to repeat the impertinence. Living, as I do, two hundred miles from London, it is no wonder that I have only just seen that a public dinner is to be given to you on the 20th of July, and a testimonial is also to be presented. I am so very poor that I cannot afford to add to the testimonial, much less to make a journey to London. But this makes me the 
more anxious to express to you, by letter, the unfeigned respect $I$ feel for you, and the great pleasure it would give me to be able to join in any mode of testifying my sense of your admirable conduct in a profession which is surrounded by no small difficulties in the way of a man's duty.

"It would give me particular pleasure, as a clergyman, to attend your dinner (as I attended Mr. Macready's farewell dinner); because I have a special abhorrence of the cant which pretends that it is improper for a clergyman to see a play. I believe that I have enjoyed as pure pleasure, as refined and as sweet, as I am capable of enjoying, in a theatre.

"I should have liked, also, as an old Eton master, who have acted with Lord Carlisle at the Datchet Lane Theatre, to have expressed, by my presence, my gratification at finding that Eton can fit a man for anything. "Wishing you all possible prosperity and happiness, "Believe me,

"Yours most sincerely, 66 , 


\section{CHAP'IER XVII.}

BANQUET AND TESTIMONIAL TO CHARLES KEAN AT THE ST. JAMES'S HALL, ON THE 20TH JULY, 1859-SPEECHES ON THAT OCCASION-CONCLUDING SUMMART.

The Dinner took place, as arranged, at St. James's Hall, Regent-street, on Wednesday, the 20th of July. An intermediate change of Ministry having called the Earl of Carlisle, who was to have presided, to Ireland, to resume the office of Viceroy,-in his unavoidable absence the chair was most ably filled by his Grace the Duke of Newcastle.* He entered the banquet room a little after seven o'clock, and took his seat on a raised dais running along the breadth of the Hall, having on his right the guest of the evening, and on his left the Right Honorable W. E. Gladstone, Chancellor of the Exchequer. In the height of parliamentary business, these two distinguished statesmen found time to honour the occasion by their personal attendance. Amongst the committee who sat down at the cross table were Viscount Exmouth; Lord John Manners, M.P. ; Lord Ernest Bruce, M.P.; Lord Robert Clinton; Colonel the Hon. James Lindsay, M.P.; the Right Hon. Spencer Walpole, M.P.; General Sir John Burgoyne, G.C.B.; Sir Walter Minto Farquhar, Bart., M.P.; Sir Walter Stirling, Bart.; C. H. Selwyn, Esq., M.P.;

- It is a remarkable incident that Lord Carlisle, was thus, by the interference of political duty prevented for the second time from presiding at a banquet given in honour of MIr. C. Kean. A similar difficulty presented itself in 1838. 
Sir Francis Hastings Doyle, Bart.; Mr. Serjeant Kinglake, M.P.; W. Vansittart, Esq., M.P. ; Thos. E. Moss, of Liverpool, Esq.; W. Platt, Esq.; W. C. Long, Esq.; P. L. Powys, Esq., M.P.; Lewis Loyd, Esq.; Chas. E. Johnston, Esq.; the Rev. R. Lewis Browne; Lieut.-Colonel M. Bruce; Sir Erskine Perry, M.P.; Sir J. Johnstone, M.P. ; Beresford Hope, Esq., M.P. ; and T. H. Taunton, Esq., honorary secretary. In the general company, amounting to five hundred and fifty (the full number the Hall would contain), were Mr. W. M. Thackeray; Mr. Clarkson Staufield; Mr. David Roberts; Mr. Sims Reeves; Mr. John Timbs, F.S.A.; Mr. Godwin, F.S.A.; Mr. Donne; Mr. Lovell, and many other distinguished representatives of literature, law, the fine arts, and the drama. The Universities of Oxford and Cambridge were respectively represented by their members. Behind the Chairman was placed a marble bust of Mr. Kean, by Bailey. The entertainment was graced by the presence of nearly four hundred ladies in the galleries, who gave an unwonted brilliancy and animation to the scene. Mrs. Charles Kean entered the balcony during the dinner, and was received with enthusiastic and longcontinued plaudits, which she acknowledged with much grace and feeling.

The dinner being over, and "Non nobis Domine" having been sung by the choir of Eton College,

The noble ChaIrman proposed "The Queen," which was responded to with the customary enthusiasm, and followed by the "National Anthem."

The next toast was "The Prince Consort, Prince of Wales, and the rest of the Royal Family." The Chairuan, in proposing it, expressed a hope that the Prince of Wales, in his next tour, would pay a visit to some of the great colonies of England. (Loud cheers.) 
He also spoke in terms of high eulogy of the Duke of Cambridge, who, he said, was deroting the whole of his energies to the reorganisation of the British army.

The toast was drunk with the utmost cordiality.

Then followed "The Army and Navy," to which General Sir J. BuRgoyne replied.

The Chairman again rose and said: "Gentlemen, I now approach a theme for which I unfeignedly say I feel myself incompetent-a task from which many a man better fitted than I am might well, not to his discredit, shrink; a task which I do not hesitate to say I deeply regret has not fallen to the lot of him who was originally intended to perform it (the Earl of Carlisle). Allow me, before proposing this toast, to say a word with reference to the origin of the present banquet. You, or at least many of you, know that every son of Eton looks back with feelings of the tenderest affection to the school in which he was brought up. Many of you who were not educated at Eton may know that there is a freemasonry amongst us which draws us together under whatever circumstances, and in whatever quarter of the world we may be thrown. (Hear, hear.) Well, then, we, Etonians, contemporaries of Charles Kean (cheers), felt that whilst we enrolled in our archives the names of some of the most distinguished men which this country has produced (hear, hear)generals, statesmen, philosophers, poets, and others, we had now a son of Eton who had brought fresh lustre on the school to which we belonged, and of him therefore we were anxious to prove our admiration. ("Hear, hear," cheers, and a cry of "Bravo.") But we felt at the same time that in such a demonstration it was the right of all to join. (Cheers ) We, Etonians, initiated it, but we felt that it was proper to call upon you to participate in it. (Hear, hear.) We felt that the fame 
of Charles Kean is the property of all; nurtured it was at Eton, but it has grown with his growth, and is now the property of his age and of his country ; and therefore we have invited you all to meet at this banquet and to join in that testimonial which is to be the consequenee of it. (Cheers.) It would occupy too long if I were to attempt to give to you anything like a biography of our guest, but I may be pardoned if in this assembly, initiated by Etonians, I mention that it is now thirtyfive years ago since he and $I$, and many others at this table, were first associated together in that school. (Hear, hear.) That as a seholar he was distinguished you may judge from what you have seen of him in after life. (Hear, hear.) That as a boy he was popular I may appeal to the friends who are assembled around me at this table. ("Hear, hear," and great cheering.) But that he was no book worm merely, I may prove by the fact, that whilst the honorary seeretary of this testimonial was the captain of the boats, he was the second captain, and pulled the stroke in a mateh of six ; and it is a curious fact that four out of those six are at the present moment in this room. (Hear, and cheers.) Nay, such was his prowess, and such was the honest rivalry, which in that day as in most others, produces friendship, that he and the honorary secretary pulled the rival tens, and I believe it was a drawn match-at any rate, it was celebrated by a breakfast of the joint crews at the "Christopher." (Cheers.) In the very year that he left Eton he entered upon the stage. It would be impertinence in me to refer to the circumstances which induced that step, but I may mention as an additional element of eredit to that eareer that his education had not tended to any such course. I believe that in six years from that time he performed on the boards of Covent-garden for the last time with his 
distinguished father who died shortly after. (Great applause.) And upon that occasion he also acted with another-with Miss Ellen Tree-(cheers, the whole of the company standing up and waving handkerchiefs and hands to Mrs. Kean, who was in the gallery) -with her who has been the partaker of all his labours and all his glories, and who is now the happy participator in the honours which are thrust upon him. ("Hear, hear," and cheers.) Gentlemen, it would be absurd in me, even if I were not too long encroaching upon your time, (cries of "No, no") to attempt anything like a description of the state of the Stage when Charles Kean entered upon it; but I may allude to this fact, that for some time before, there had been a complete severance of dranatic poetry from the theatre; and whilst dramatic poetry oceupied the highest position in the imaginative literature of this country, whilst every body delighted in the poetry of the Elizabethan era in the closet, Shakespeare was excluded, or nearly so, from those boards upon which it had been his purpose and delight to introduce the most beautiful conceptions of his genius. (Cheers.) To avoid this evil, and to introduce a reform in such a matter has been the object of Mr. Kean's life. Gentlemen, in the days of ancient Greece, the theatre and the drama were the most effective instruments in forming the character of that remarkable people; and if it is not the same at this moment, it is at any rate an index to the social status of a people, and we may trace in succession the feelings, and sentiments, and moral opinions of this country if we look back to the coarseness of language-and coarseness, I believe, of language alone-which prevailed in the time of the Tudors, degenerating into actual obscenity, and, what is worse, profligacy of thought and sentiment in the time of Charles the Second, followed up by the frivolity of 
subsequent times. We shall see, I believe, now, if not a complete revival of what we would earnestly wish to see, at any rate we shall find a material improvement in the tastes and sentiments of the present day. (Hear, hear.) I have referred to ancient Greece. In Greece the actors of that country were considered worthy of the highest honours of the State; and it is strange, indeed, that, in this land of literature and art, whilst other followers of art, whilst sculptors, painters, poets, receive, at any rate, some portion and meed of praise, of approbation, and of respect, and, so far from grudging it them, I say they do not receive so much as they ought-(cries of "Bravo," and cheers) - I say that it is strange that while they, at any rate, receive some honour, that branch of art the most rare, the most difficult in which to arrive at excellence, seems to have been cast into the shade, and treated almost with obloquy; - at any rate, with indifference. (Hear, hear.) Honour, I then say, to the man who has raised the stage from what it was when he entered upon it to what it is now. I do not mean to say that he found it in such a low state as $I$ have represented it to have been in former days, but he has raised it materially; and he has introduced reforms, begun by the great Garrick, followed up by the two Kembles and his own father, and now matured, and improved, and increased by himself. (Applause.) I allude, of course, to what have been called his Shakespearean revivals. We all know their merits; we have heard them criticized; but they have outlived eriticism. (Hear, hear.) But his fame does not rest alone, howerer greatly a portion of it may, upon these Shakespearean revivals. He has shown a versatility in his art; he has shown a knowledge of the human character; he has shown the influence of mind over the passions of men; he has 
shown all these qualities in a way which proves that he is no copyist, that he is not a mannerist, that he is not a man with one idea only. (Cheers.) Moreover, he is a great historical painter. I see some distinguished professors of the art of painting in this room, and I ask them whether they do not look upon Mr. Kean as a rival in the art, only that their productions, happily for them, descend, fresh as they came from their easels, to posterity; his, unhappily for him, perish in the same evening, and leave nothing but their fame behind them ? (Hear, hear.) His sceneries are not only lessons in art, but they are lessons in history. (Hear, hear.) We have become, of late years, many of us, attached to archæology. I look upon $\mathrm{Mr}$. Kean as one of the greatest archæologists of the day. (Hear, hear.) He has had a reason for everything; there is nothing which lie introduces upon the stage for which he has not authority, and you may see living representations of Shakespeare's characters, with the exact costume, the exact scenery, the exact furniture of the rooms which, there is every reason to believe, from pictures and other sources, existed at the time Shakespeare represented. But he has done more; he has introduced groups upon the stage which approach to a marvel in merit; the way he has organized them, the way he has dealt with them, the way he has brought them upon the stage, moved them, and, when they have played their part, removed them-would be worthy of any general in the service. ("Hear, hear," cheers, and laughter.) He has, in acting Shakespeare, answered the question of Shakespeare himself-

"Can this cockpit hold the vasty fields of France?"

and Mr. Kean has proved that his cockpit could; and if it were said that it could be done in any but his 
theatre, it would be believed to be impossible. Well, but in what spirit has this been entered upon? It has been in no commercial spirit. (Cheers.) Not neglecting the interests of his family - and we should all have less respect for him if he did (hear, hear)-I say, not negleeting the interests of his family, he has nevertheless been actuated by a pure love of art, by a love of his profession, by a noble spirit. (Hear, hear.) He no doubt feels the truth of the lines,-

"The drama's laws the drama's patrons give,

"For those who live to please must please to live."

We acknowledge that sentiment; he has not been improperly influenced by it; he has never allowed the love of gain to induce him to swerve for one moment from that elear line of duty, I may call it, which he has ehalked out for himself; he has followed his career regardless of every selfish consideration (hear, hear), and I am certain he now has his reward in the approval and admiration of his friends and the public. (Cheers.) At the same time, his hand has ever been open to assist the poor and needy (hear, hear,) more especially if they have belonged to his own profession. I need only reeal to you the meeting in the Prineess's Theatre about twelve months ago, when he eloquently advoeated the cause of the Dramatie College (a voice, "What has become of it now?"), and proved that not only was his eloquence at the service of this charity, but that his purse was ready too. (Hear, hear.) Now then, gentlemen, as our guest has to follow me, I should indeed stand unjustifiable before you if I said one word more in adrocating this testimonial. You know his public merits ; many of you know his private virtues ("hear," and cheers), and therefore I will only say that I now ask you to drink to the health of one whose virtues and 
whose private character have brought around him a wide circle of affectionate and admiring friends; - to one whose zeal in his profession, amounting almost to enthusiasm, has led him to prove that, the theatre may be made, not merely the vehicle for frivolous amusement, or, what is worse, for dissipation, but that it may be erected into a gigantic instrument of education for the instruction of the young, and for the edification as well as amusement, of those of maturer age. (Cheers, which lasted some time.) I ask you to drink his health as one who has exalted the character of the English theatre; I ask you to drink his health as one whose benevolence and charity many down-trodden brothers and sisters of his art have felt and blessed (hear, hear) ; I ask you to drink his health as one who by his genius has illustrated, and by his character has elevated, the profession on which he has entered (applause); and, finally, I ask you to drink his health as one whom I may term, if figuratively, at any rate without exaggeration, as the hierarch of that glorious temple in which Shakespeare is enshrined." (Loud and long-continued cheering, in the midst of which the noble chairman sat down.)

The toast was drunk by the company upstanding, amidst enthusiastic cheering and waving of handkerchiefs on the part of the ladies. Every point in this admirable speech told upon the listeners; and nothing more forcibly than the tone of personal kindness by which it was pervaded.

The general excitement having somewhat abated,

Mr. KEan, on rising to return thanks, was rapturously applauded. He said-_ My Lords and Gentlemen, when I entcred this room and took my seat in prescnce of this distinguished company, as the invited guest of the evening, I felt and appreciated at its full value, and, I trust, with becoming pride, the flattcring position to 
which your favour has exalted me; but it was impossible for me to anticipate the kind and gracious eulogiums of the noble chairman, so warmly and eloquently expressed, and your enthusiastic response, which I may truly say has completely overpowered me. (Cheers.) I am totally unable to thank you as I ought or as I wish. I throw myself on your indulgence, entreating you to believe in the sincerity of $\mathrm{my}$ feebly uttered sentiments, and to pardon the poverty of my language in consideration of the overflow of $\mathrm{my}$ heart. (Cheers.) Amongst the leading influences of human character the ties of kindred occupy a foremost rank; next to these, perhaps, may be placed the associations of boyhood, the remembrance of those happy days, at school or college, when life "first put forth the tender leaves of hope;" when all was spring and sunshine; when our young minds were cngrossed with the present, and the gathering clouds of the future were unseen or disregarded. (Sensation.) All these thronging visiuns of the past come back upon me at this moment, after the lapse of more than thirty years, with the freshness of yesterday, and with that pure enjoyment which only such revived feelings can impart, as $I$ look upon many of the faces by which I am surrounded, and cousider the originating impulse that gave rise to the present brilliant assemblage. (Cheers.) To be thus recognised and presented, as it were, anew to the public as the fellow-student and early companion of men who have inherited or achieved the highest honours and the purest fame-men as universally esteemed for their talents, their integrity, and their benevolence, as for their exalted rank and social importance-(cheers); such a crowning episode in the pilgrimage of life is surely more than enough to compensate for years of toil, and to obliterate for ever the memory of past struggles, anxieties, and disappointments. (Clieers.)

vil. II.

I $\mathrm{B}$ 
How, also, am I to find words in which to convey my sense of obligation to my unswerving patrons and supporters-the public; that publie who have so frankly and generously responded to the present call, and whose eo-operation was ever ready to promote what I conseientiously believed to be the blending of their most intellectual recreation with a true development of the best purposes of our national drama. Let me offer to their representatives here my heartfelt gratitude-

\section{"Only I have left to say}

More is thy due than more than all can pay."

You have done me a great honour-the greatest possible honour that could be conferred on a member of the theatrical profession, and, eonsequently, on the dramatic art itself; - that art, the progress and prosperity of which cannot be otherwise than a subject of interest to every reflecting and educated mind; for the legitimate object of the drama is to eontribute to the intellectual culture of mankind - to expose to view the secret springs of action, the most minute vibrations of the human heart; to exhibit the character of man under all its various and conflicting passions; to inspire sentiments which may serve the purposes of truth and morality ; -whose end, as Shakespeare has told us, both at the first and now, was and is, " To hold as 'twere the mirror up to nature; to show virtue her own feature, scorn her own image, and the very age and body of the time, its form and pressure." (Cheers.) When these objects are not attained, the drama has not fulfilled its mission. It is not beeause the stage may be degraded from its higher purposes that its benefieial influenee should be overlooked or rejected. (Cheers, and cries of "Bravo!") All human institutions must necessarily be defective in their organisation, as comprising 
within themselves mingled elements of good and evil. Imperfect in their source, they cannot be otherwise than imperfect in their exercise. The effect depends upon the care with which these elements are regulated, and the utmost that can be hoped for is a preponderance of good. (Cheers.) Thus, in the natural world, we find plants possessing the contrasted ingredients of health and destruction. Shakespeare has described this in one of his most familiar passages -

"Within the infant rind of this small flower

Poison hath residence and medicine power ;

Two such opposed foes encamp them still

In man as well as herbs, grace and rude will ;

And where the worser is predominant

Full soon the canker death eats up that plant." (Loud Cheers.)

These lines contain a brief but comprehensive moral, which may be applied not only to the stage, but to everything in life, of whatever class or quality. It may be difficult to preserve a garden free from weeds, but who for that reason would root up the flowers, or abandon them to be choked? (Cheers.) That which contains certain advantages to society at large, surcly should not be disregarded as an instrument of good because it is capable of misapplication. Its use, and not its abuse, should be rendered most prominent, and its influence encouraged as a humanising agent in embellishing life, refining taste, and imparting knowledge. (Cheers.) Let it be remembered, in the words of our own immortal poet,

$$
\text { "It is in ourselves that we are thus and thus;" }
$$

and that

"There is good in everything."

(Cheers.) The love of the drama is inherent in our nature, and must have been implanted there for some beneficial purpose. For ages it has employed the loftiest intellect, and has asserted universal sway over 
the heart and mind of man. In no country throughout the world, past or present, has the poetical drama reached such perfection as in England, for the annals of genius and civilisation include but one Shakespeare. (Cheers.) A stream of light has been poured upon the world's surface by that brilliant luminary which no change can darken, no time can obliterate. (Cheers.) He casts his rays over the highest and the lowest; his influence is felt by every class and grade; his authority has been appealed to by the advocate, the judge, the statesman, and the divine; he has furnished texts for science, philosophy, patriotism, affection, charity and religion itself. (Cheers.) Truly has the great moralist, Dr. Johnson, said, "Shakespeare is a mine which contains gold and diamonds in inexhaustible plenty. His plays are filled with practical axioms and domestic wisdom. From his works may be collected an entire system of civil and economical prudence." And surely Dr. Johnson was right, for where shall we find such boundless versatility of thought and reasoning, such consummate knowledge of the human heart, with all its complicated mechanism? such golden precepts to improve the conduct of life, and render men wiser, as well as better? Not a turn of thought-not a fluctuation of feeling, was unknown to him; for his comprehensive mind reached everything, glancing "From heaven to earth, from earth to heaven." His faults reflect the manners of the day, not the character of the man. (Cheers.) Had the theatre never existed there would have been no field for the exercise of this mighty genius; and who will be bold enough to assert that a mere liuman being was thus inspired by a benign Providence for any other purpose than the advantage of his fellow-creatures? (Loud Cheers.) The stage is the surcst medium through which the 
precious gems of this intellectual mine can be scattered amongst the multitude; and, as actors, we may well be proud to be thus considered the trustees of this mighty treasure. It is our peculiar privilege to bring generation after generation face to face with the poet himself, giving vitality to his works in a manner which appeals to the senses, and teaches while it fascinates. The more Shakespeare is known to the million, the greater amount of beneficial influence will be spread abroad, and such a result is not to be anticipated from the student in his closet, but from the actor in the theatre. In "Murphy's Life of David Garrick" an incident is related which may not be uninteresting to the present company. It is there stated that about the year 1737, amidst the darkness which immediately preceded the advent of that wonderful actor and distinguished man, the master works of our great poet were comparatively neglected, and had given place to frivolity and folly. The drama had, in fact, sunk into an abject condition. To the honour of the ladies of that day, it is told that, feeling the unhappy degradation of the national stage, a subscription was set on foot by them to dethrone buffoonery and restore Shakespeare. (Cheers.) Should we ever again so far degenerate as to turn aside from the right path, I would appeal to "that heaven of beauty which now shines full upon us," entreating them to invoke the daughters of England to hasten to our rescue, that under their angelic guidance we may be led back from our erring way into the lost track. Then might we say with the poet--

"O woman, woman, thou wast made

Like heaven's own pure and lovely light.

To cheer life's dark and desert shade,

And guide man's erring footsteps right."

(Cheers.) My lords and gentlemen, no words of mine 
can convey my gratitude for the priceless compliment you have bestowed upon me. I can only say that ' $m y$ ' endeavours have ever come too short of $\mathrm{my}$ desires, yet fil'd with my abilities.' The memory of this day will be cherished by my representatives when I am no longer amongst them, and I hope and believe will serve to stimulate the efforts of the rising actor, awakening in him the reflection that in the honourable exercise of his vocation there is one reward ever open to him which no obstacle can prevent, no prejudice can withhold-a prize above all others to which he should zealously and steadily direct his aim-respect from the respected." (Mr. Kean resumed his seat amidst reiterated peals of applause.)

The Cinancellor of the Exchequer, then proposed in eloquent terms "The health of the Chairman," which was most enthusiastically received. In the course of his speech, referring to the occasion of the meeting, and the guest of the assembly, he said-"I can, too, render witness to Mr. Kean as being a public benefactor. (Hear, hear.) If anything could add to my individual satisfaction in rendering that witness, it would be the circumstance that I am politically connected by representation, and have for many years been connected, with one of the great seats of learning and education in England. (Cheers.) I see in our friend one of those who has ever asserted the social brotherhood that exists between all true and genuine instruments of human cultivation. (Hear, hear.) He has said truly that in the Drama the greatest powers of the human mind have been exhibited. This most influential instrument, which has sometimes grovelled in the mire, and which has rarely been appreciated to the full extent of its capacity, Mr. Kean has devoted almost immeasurable labour to raising up to its due and natural 
elevation. This is the service that he has conferred upon the age; this is the service that we are here to commemorate ; and I pray you to drink, as it ought to be drunk, the health of my noble friend, the Chairman; because he has given us the advantage of his presence, of his carefully matured thoughts, of his powerful expression, in order to convey to the world that which we feel, and that which we desire to say and record. I commend to you 'The Health of his Grace the Duke of Newcastle.' "'

The noble Chaikman in his reply used an expression which called forth repeated plaudits. "We are met here," he said, "without political animosity or jarring feelings of any kind, ministers in office, and ministers out of office, to join in a common tribute to one who, without being of any party, belongs to and is recognized by all."

Then followed the tonst of "The Honorary Secretary," H. 'T. Taunton, Esq., which was also warmly responded to.

The Champan, in eloquent and appropriate terms, gave "The health of Mrs. Kcan," which produced another remarkable display from the assembled company. "I am conscious," said the noble Duke, "that I stand in the presence of that lady, and I know enough of her delicacy of mind, to know that it would be most unpleasing to her, if upon this occasion, and in so large an assembly as this, I were to enter into any lengthened eulogy of her character. (Cheers.) I know that she will only value the compliment which we now pay her as reflecting upon her husband, and as. showing that she has participated in all his labours. She has shared in his triumphs, and she rewards his labours by her devoted affection. (Cheers.) But I may be allowed, even in her presence, to say that she has 
exhibited a bright example to the English Stage in her career. (Hear, hear.) In no respect have Mr. and Mrs. Kean brought greater honour upon their establishment -in nothing have they more distinguished themselves in their management of the Princess's Theatre, than in the interest which they have shown in the almost domestic and affectionate care which has been taken of those who are engaged there. (Great applause.) They have watched over their interests; they have watched over their morality and their happiness. (Hear, hear.) They have attenderl to their health; they have made the Princess's more like a great domestic establishment than a public institution in which people have no care for those who serve them, provided they fulfil the duties they have to perform. I say, then, honour to them, and especial honour to Mrs. Kean in setting so bright an example." (Loud cheers.)

Mr. KEAN in reply said- "The graceful manner in which Mrs. Kean's name has been introduced to your notice through the kindness of the noble chairman, and the enthusiasm with which that name has been received by the present company, is indeed most gratifying to me. The compliment which I feel so deeply, is, I know, equally felt by my wife. Permit me, however, to intreat that in my anxiety to spare your time, you will not estimate the amount of our mutual gratitude by the brevity of my reply. (Hear, hear.) Amidst the complicated duties of management, the director of a theatre, like the general of an army, requires the assistance of an efficient staff. Mrs. Kean has been my first aidede-camp, and never had commander one more able and more indefatigable. (Loud cheers.) She has been my solace in the hour of trouble, my counsellor in the hour of need. Her courage never flagged, her heart never failed. I may truly quote the words of Solomon :-- "She 
openeth her mouth with wisdom, and in her tongue is the law of kindness." Once again, my lords and gentlemen, accept my heartfelt thanks for the honour you have conferred on my partner, friend, and wife." (Prolonged cheering.)

The last toast was, "Floreat Etona," proposed by Mr. Spencer H. Walpole, M.P. He said, "We are now about to terminate our proceedings; we terminate them with this epilogue, viz., that we hope that all Eton men who succeed us will have the same good fellow-feeling towards their fellow-Etonians, that wherever they succeed honourably and nobly in life, we will be the first to pay them the compliments of that success; and success was never more signal, never more marked, and a reputation for it never more justly earned, in my opinion, than it has been by the way in which Mr. Kean has revived the nobiest specimens of dramatic conception, in which he has pourtrayed to us the history of every country by his representations; and, let me add (for that I am creditably informed is the fact), for the noble manner in which he has protected every one who has come under his care. (Cheers.) At this late hour of the evening, I will say no more except this, that though there are many liere who are not Etonians, you will, one and all of you, agree with me in this, that as long as Etonians act in the spirit of gentlemen (hear, hear), the spirit of honour and duty (hear, hear), that noble spirit of wishing their fellow-students to succeed better than themselres, so long will you drink with me the toast which I propose, 'Floreat Etona.' "'

The toast was then drunk, and the band having struck up "Auld lang syne," the company separated at half-past eleven.

The diuner and wines were of a superior description, and redounded to the credit of Mr. W. Donald. 
The subscription list for the "Kean Testimonial" will be kept open until the 1st of May, 1860. It was announced by the Hon. Secretary that the amount already execeded $1,000 l$. That sum will in all probability be doubled before the above-named date.

No public man, of whatever position or profession, has ever received a greater compliment, or a more unequivocal evidence of public approval, than that conferred on Mr. C. Kean, on the 20th of July, 1859.

On the 29th of August, Mr. C. Kean retires finally from the management of the theatre he has so gloriously exalted. His last play will be "Henry the Eighth." For years he may continue to delight the public with his unrivalled powers of acting, and will in all probability add many thousands to his realized fortune. But he cannot ascend to a loftier eminence of fame than that which he has already reached, while neither time nor rivalry can wither one leat of the laurel crown he has so triumphantly won. He has encountered many obstacles, but enduring courage has enabled him to set them all aside. He owes much to his own self-reliance, based on upright prineiples, and innate integrity of heart and purpose. His genius has never burned with a flickering light; his perseverance has never faltered on the roughest track. The public, for a long series of years, have never chilled him by indifference or cold ap. plause. He has been fortunate, but he has thoroughly deserved his prosperity. And, in summing up the favouring agencies that have smoothed his path, and accelerated his progress, let us name with just acknowledgment the warm, unflinehing, and powerful advocacy of the high and independent portion of the press-that mighty organ - which has ever proved his sure citadel of strength, against a few stubborn, though unavailing attacks of prejudice and personal hostility. 
A P P E N D I X. 



\section{A P P E N D I X.}

A. Vol. ii. p. 71 .

Notice on "Faust and Margutrite," from "Punch," of 6th of May, 1854 (copied into Lloyd's of May 7th), accompanied by a Caricature of Mr. C. KEAN.

Poodle Mephistopheles at the Princess's. - "No man, like a Frenchman, can trim a poodle. This, we believe, may be conceded as a national merit. No man, like a Frenchman, can so quickly teach a poodle so many tricks; to fetch and carry; stand on three legs; pick letters from a biscuit alphabet; and, in a word, do all the things that make the cleverest of dogs. The skill of perfect teaching cannot be denied to the patience and intelligence of French genius; and, assuredly, Mons. Carré has marvellously vindicated the Gallic ability by so trimming and teaching Goëthe's Poodle, alias Mephistopheles, that his originator would never know him again.

"'Seest thou the black dog'-says Faust to Wagner-'ranging through the corn and stubble'?

Faust. "Mark him well! For what do you take the brute? Wagner. "For a poodle who, in his way, is puzzling out the track of his master.

Faust. "Dost thou mark how, in wide spiral curves, he quests round and ever near us ? and, if I err not, a line of fire follows upon his track.

Wagner. "I see nothing but a black poodle. 
"Such was the conviction of Mons. Michel Carré ; and so in 1851, he goes to work, and trims and shapes Goëthe's poem of Fraust into a thing for the French stage : and the thingpoodle-like-having had its run upon all-fours in Paris, may now be seen under the very moral management of Mr. Charles Kean, in Oxford-street. A mere poodle; and-for a poodleone of the dullest dogs that ever defeated a teacher. But that the poodle should have been trimmed by a Frenchman was, doubtless, its excelling recommendation to a manager who prefers his plays, even as his gloves, to be of Paris make. They can be so stitched to fit, and be held so easily in hand!

"For what could the startled, confounded manager have done with the Mephistopheles of Goëthe? He would have shaken at its power; and haply, have transgressed under it, like a poodle itself scared and frightened by Jove's thunder and lightning. Now, poodle Mephistopheles, as trained and taught by Mons. Carré, was an animal not beyond the powers of the master of the Princess's revels-a puppy-dog to be led in a string, or carried under the arm, even as puppy-dogs are tethered or borne by flunkeys.

"'Driven behind the stove'-(raves Faust of the real poodle, Goëthe's poodle) 'it is swelling like an elephant; it fills the whole space; it is about to vanish into mist. Rise not to the ceiling! Down at thy master's feet! Thou seest I do not threaten in vain; I will scorch thee with holy fire. Wait not for the thrice-glowing light. Wait not for the strongest of my spells."

"Now here are thunderbolt words, and scathing conjurations, that a common manager, a merely simple provider for a simple public, can hardly be expected to confront and live through. And these things are Goëthe's poodle: but the Frenchman teaches the dog to answer to a very different sort of order : hence, when the poodle or Mephistopheles of the Princess's enters upon his two legs, he runs in with no more of the devil in him than may be expected of the dullest of footmen, with just enough of spcech to be stupid upon any subject, and on the very shortest notice. Never was poodle cut so bare-shorn 
so close that the very skin has been nipped by the scissors, and still shows the unsightly wounds-never was poor poodle so maltreated as Goëthe's tremendous black dog by the irreverent Frenchman. Nevertheless, an easy critic has declared in favour of M. Carré's dog, as it appears in the hands, or upon the arms of Mr. Charles Kean,-saying in justification of the clipping and exposure of the poodle, as shown at the Princess's-

" One person, if he had now been living, would have decided on the wisdom of the manager, who having an effective Easter piece in view, selected the low-art fabrication of $\mathbf{M}$. Michel Cârré, in preference to the high-art creation of the German poet. The person we mean is-Goëthe himself.'

"Just as it might be said, 'one person, when Mr. Charles Kean shall enter into an Elysium, will at least step forward and embrace him for lis acting of Shakespeare, with every conceivable and inconceivable scenic effect, and the person we mean is-Shakespeare himself !' Even as Goëthe might hug and thank Michel Carre for his 'low-art fabrication' (his low cutting of the jacket of the poodle), so will Shakespeare embrace Mr. Charles Kean for his fabrication with very low cuttings of Cibber's Richard the Thive. Wonderful must be the sources of gratitude in the Fields of the Blest !

"The Faust and Marguerite-at the Princess's-shows Mr. Charles Kean to be a born spectacle-maker. . . . . . . Wonderful is the process by which all the poetry, all the grandeur, is discharged from Goëthe, the imagination and subtleties of the Master being supplied by the pulleys of the machinist and the colours of the scene-painter! Everything of life and beauty has been extracted, and a caput mortuumthat is, Charles Kean's Mephistopheles-remains.

"And yet Mr. Kean never acted so naturally in all his life. He was quite doun to the part; his perceptions of the poetic trotting upon four legs. He, no doubt, felt the triumph of common-place, and rejoiced in his element. We have been accustomed to associate with Mephistopheles a devilish subtlety ; a laughing spirit in the eye, burning like a burning-glass. Mr. Kean was more consonant with his poodle-trimmer: he had 
no more subtlety in his speech than the waiter at the Dog Tavern; nothing more scorching in his looks than might flash from brass buttons. There was boldness, but no burning.

"Some of the scenic effects are very beautiful, and worthy of the Princess's as a gallery of illustration. The vision of Marguerite-(thanks to Marguerite herself !) was very lovely ; and the procession to the Cathedral showed that the manager had been a profound observer of the condition and demeanour of people going to prayers. The sprinkling of babies was very judicious and a little touching.

"The musical contest for the soul of Marguerite between the demons under the stage, and the angels over it, was somewhat bold upon a moral English public: but when the soul of Marguerite in white muslin, borne by angels in satin petti. coats was carried to heaven ('without wires,' cries a critic, hysterical with admiration)-the delight of the gods was perfect.

"The morality of Marguerite-as painted (in rouge) by M. Carré-gives us rather Marguerite from the Palais Royal than Marguerite from the well. We would advise Mr. Kean to take a view of the latter, so exclusively painted by Miss Howitt. It may do him good, as a royal and moral manager.

"As a piece of show and mechanism (wires unseen) Faust and Marguerite will draw the eyes of the town; especially the eyes that have least brains behind them. It is the very triumph of vulgar showiness, uninformed by a spark of genius. Mr. Kean's poodle is all over a very dull $\operatorname{dog}$; a dog without a bit of the wag in him, even in his tail.

"Nevertheless there is one triumph due to the actor. His new nose is perfect: it has the true demoniacal curve. We never saw a better view of the Devil's Bridge." 


\section{B. Vol. II. p. 92 .}

Extracts from "Lloyds Weekly Newspaper."

"Nov. 12th, 1854.

Old Clothes at the Princess's.-_ Again does this theatre appear as the old clothes-shop to the Standard. Schamyl haring been worn to tatters at Shoreditch, the rags are picked up, and-newly-dyed-are flaunted in Oxford-street. We have not seen the sccond-hand tatters, but the Daily News says of the article, that 'Schamyl, the Warrior Prophet, as produced at the Princess's on Monday evening, is a piece without any dramatic pretensions, either in construction or dialogue; but merely a thread upon which to hang a series of striking tableaux, let off a good deal of gunpowder, and explode some rather second-rate jokes at the expense of the Czar Nicholas and the Russians in general. It is confessedly an importation from the Porte St. Martin, and exhibits all the bold licence as to the unities that becomes its parentage, including a lapse of twenty years between the latter portions of the warrior prophet's career.' It is said that the manager is so addicted to things 'from the French,' that he eats none but French eggs: and not then until very stale."

\section{"January 14th, 1855.}

"There has been nothing new, worthy of any attention, this week. The pantomimes are in full run, and the burlesques in full trundle. We fear, however, that, like St. Petersburgwhatever shows and seeming festivities may abound-the theatres feel the war. $\mathrm{We}$ are promised 'a new comedy' at the Olympic. Something, we hope, worthy of the company and the management,-and not inevitably French.

"The Yellow Dwarf will, we should think, give good change to the treasury. Robson's Dwarf is admirably devilish. Bits of his tragedy are especially fine. We wish, by the way, that 
he would charitably play Hamlet for the edification of MIr. Charles Kean, who has of late been attempting the Prince of Denmark. After the attempt, Mr. Kean was, it is said, as well as could be expected; but as for Ilamlet, he was so dreadfully mauled that even his parent, Mr. William Shakespeare, would not know him.

\section{"January 21 st, 185.5.}

"Louis the Eleventh.'- Was played two years since at Drury-lane, when Mr. Darenport acted with very considerable and very varied powers, the monster king. The same piece has been got up at the Princess's. We confess that we had not the courage to encounter the five dreary acts, having once endured them. The piece is a piece of one part. Louis, like a tape-worm, goes through it. Certain critics have, in Mr. CKean's own written words to the lamented Moran, 'come it very strong' indeed. One calls Mr. Kean 'sublime!' another quotes, in allusion to the worn out-state of the actor when summoned for reward, the words of Napier, 'the laurel is nobly won when the victor reels as he places it on his blceding front.' Thus, we are to suppose how, on Saturday, Charles Kean reeled to his dressing-room under a load of greens. The picture is very touching. Another critic-a venerable hand-avouches that no actor could have acted like Charles Kean except David Garrick. And why not? Listen,- 'Edmund Kean would have been too invariably impassioned; Macready too sombre; John Kemble too stately; Cooke too coarse; and Young too humorous. To get an adequate representation we must travel back to David Garrick. He could have done it all.' But we have no need of David, seeing that we rejoice in Charles. Garrick died in 1779 : but on the authority of a living critic, David could have done it all. Is not this coming it a little too 'strong?' To name Edmund Kean, father, with Charles Kean, son, is to compare the intellectual might of Cain with the crow-bar force of Jack Shepherd. MIr. Charles Kean has, we have never denied it, a certain amount of power for raw- 
head melodrama ; but he is no more susceptible of the metaphysical subtleties of pure tragedy than was 'Peter the Wild Boy.' The Daily Nevos speaks of the suecess of the piece as moderate; and of much of Mr. Kean's acting as mere rant. Other Daily critics are, however, quite hysterical with rapture. Falstaff' averred of Hal that the Prince had given him 'medicines to make him love him.' Have these critics unguardedly taken medicines, or what ? . . . . .

"The translation of Saturday-it is agreed upon all handswas very handsomely got up. We have no doubt of the fact. When the manager is the sole portrait in the fore-ground, the daub is certain to have the biggest of golden frames.

\section{“January 28th, 1855.}

"'Tine Pet axd tile Victin.'- "The Spectator puts the condition of Charles Kean a little pathetically. He is at once a pet and a victim ! He is, says our contemporary, 'constantly patronised by the court and higher classes, and constantly satirized by the wits.' In such contests, the wits have invariably had the best of it. A man cannot have letters patent making him a great actor, as a man is patented breeches-maker to the king. George the Second refused the dulness of his German countenance to poetry and painting: he arowed that he 'hated boetry and bainters :' nevertheless poetry and painting were not blighted by the royal aversion. Genius, fortunately, is independent of courts and aristocracies ; or what, long since, would have become of it ?"

" $F e b .4 t h, 1855$.

"Miss Rosieo,-or rather,--Miss Cushman as Romeo, has appeared this week at the Haymarket. The curiosity is not a novelty. We have before seen Miss Cushman as Miss Romeo; and though the lady lover is full of tlame, it is the flame of phosphor-it shines, but it does not burn. We could as soon warm our lands at a painted fire, as feel the inpetuous passion C C 2 
of an ungowned Romeo. . . . . The part of Julict has been played by a young lady bran-new from that nursery of the drama, Liverpool. However, Miss Swanborough we must take another opportunity to see. Certairly, there never was greater room for a young and passionate actress. By the way, as a lady acts Verona's youth, why should not a gentleman play Verona's maiden? How would the subjoined-for a novelty-look in the Haymarket playbill?

$$
\begin{aligned}
& \text { I'Romeo . . . . Miss Charlotte Cushimax. } \\
& \text { Juliet } \\
& \text {. . Mr. Citarles Keas. }
\end{aligned}
$$

"There would be attraction in this, at least for one night. Nor have we the least doubt that the representative of Julict would have at hand certain sagacious critics, who would discover in his portraiture of the virgin of Verona graces and delicacies and profundities hitherto unknown or unacknowledged. 'Miss 0'Neill's Juliet was too feeble, Miss Fanny Kemble's Juliet too forcible; whereas, Mr. Charles Kean's Juliet united the spirituality of the angelic nature with all the ardour of purely human passion.' Mr. Paul Bedford has played Polly Peachum, why should not Mr. Charles Kean play Juliet? Any way, we make a present of the hint to the Haymarket manager."

\section{"March 18th, 1855.}

"Les Jeux Innocents - translated into A Game of Romps-is the last edition to the French pastry nightly on sale at the Princess's. We learn from a friendly daily critic that it far surpasses the original. But this of course. The same critic - (a critic may be like a pair of bellows, purchased and retained to puff upon the premises)-that Mr. C. Kean's Louis $X I$. has even outlived the hard frost.- ' Neither the severity of the weather, nor the absorbing interests of passing events have withdrawn public attention from this great achievement of dramatic art, which continues to be a leading topic of con- 
versation among all play-going circles.' At this moment, the death of Nicholas in St. Petersburg is nothing to the death of Louis XI. in Oxford-street! The critic declares that-

" 'It is unquestionably the greatest triumph of the legitimate acting which the modorn stage can show, and is entitled to rank in perfect parallel with the best efforts of the mighty departed masters of earlier times, who sleep in their laurels, and are usually pronounced unapproachable.'

"More : much more. Even as a live pug may be said to be better than a dead lion, so may a yelp in Oxford-street be better than a long sleep in Westminster Abbey."

\section{"April 15th, 1555.}

"At the Princess's there was a French opera without the music; and, we are of course told, the thing was better for the want of harmony. Wring a skylark's neck, stuff it, stick it in a fixed posture, and then put it in a fine framed and glazed case; it is a much better skylark than when singing at "heaven's gate." The Princess's workman has translated lis bird from life to death, and put it-it is allowed on all hands-in a very fine case. The translation is by the stock translator; the manager, like Hissgoose, the tailor, working up his stuff on the premises. . . . . .

"In a few hours after this sheet shall be published, the Emperor and Empress of the French will have arrived in England as the guests of Queen Victoria. They are, it seems, to go in state to the opera ; they may, too, visit the hippopotami at the park-(they are at least not taken from the French); but we do not see what can be offered to their majesties at any of the theatres that they may not have witnessed in the Paris original. Certainly, Astley's, as the theatre for real English sports, is an exception; and they might make a day, calling at the Bank, the Mint, and the Tower, on their way to visit Shakespeare at the Standard, where, no doubt, Louis Napolcon would decorate Miss Glynn 
with the star of the Legion of Honour. All this is, however, a matter of conjecture; one point alone is certain. The plysicians of the Empress have, under all circumstances, emphatically forbidden her visit to the Princess's to see Mr. Charles Kean's horrible death-faces in Louis XI. If their majesties resolve to patronise the great actor 'from the French,' it is understood that Mr. Kean will receive a considerate comnand from Windsor to die in his own dressingroom."

\section{"May 20th, 185.5.}

"Hexry tile Eighti, produced at the Princess's on Wednesday, 'regardless of expense,' must wait until next week. It will keep. We are, however, happy to record the fact that the play has again restored Mrs. Charles Kean to the stage, from which-to the luss of the pullic, and equally to their regret-severe illness had too long detained her. The theatre can certainly ill spare the 'better half' of Mr. Charles Kean."

" May 27th, 15J5.

"The Pictorial 'IIexry VIII.'-Postponing to another day the task of criticising Mr. Kean's Carlinal Irolsey, as a piece of acting, let us not delay the report of the highest praise of 'Ilenry VIII.' as a piece of stage furniture. It is allowed on all hands-some of the critics have duly gone into hysterics on the matter-that fur a stage-show, Mr. Kean's last handiwork is by far the finest thing of his genius; and there is no doubt that Mr. Kean is a great, a very great, upholsterer. His Oxford-street neighbours, Messrs. Jackson and Graham, had better look well to their garlands in their carpets and hearth-rugs. A gifted nobleman has immortalised his name in a table; and l'embrokes are to be found in smallest lodging-houses. Who knows? Mr. Charles Kean may enrich posterity with an original boot-jack: or, haply, in finest 
moment of inspiration, bequeath a cribbage-board with selfacting pegs, to happier generations.

"For ourselves though not, we hope, wholly insensible to the influence of the beautiful, we would rather of the two have Shakespeare acted, than Shakespeare merely furnished. Te care not that 'Macbeth' is got up regardless of expense, if Macbeth himself is every bit as wooden as Duncen's bedstead. Thus, it is possible that 'Henry VIII.,' as presented, so to speak, under bare poles at the Haymarket, with Macready for Wolsey, may, to the lover of the art and the worshipper of the poet, be even more valuable than the Wolsey of Mr. Charies Kean with all the surrounding upholstery. According to the Times' critic-whose amiable weakness it is to press too much assistance upon those he would serve-Mr. Kean's Wolsey is especially admirable, inasmuch as he is not 'intrinsically an awful personage.' 'The butcher's son is to be seen through one of the princes of the church.- 'The look,' says the critic, 'that he darts at Campeggio, when the latter would walk before him, has a sort of "Who the d-— are you?' about it that is inimitably consequential.' Could Shakespeare see this, is it to be doubted that he too would dart a look at Wolsey, as butchered by the actor, asking in the look- Who the d-_ are you?' The critic talks of Mr. Kean's 'almost professional depreciators.' Certain writers have properly denounced such atrocities as 'Mephistopheles,' the 'Courier of Lyons,' and so forth, as so much stage pollution; and, of course, they are the depreciators of the manager who sins in thein.

"Mr. Kean has endeavoured to prepare the town for the blinding glories of his scenery and furniture, by issuing a sort of play-bill that, at least, bears his name. Certainly, there are two or three curious bits, whose paternity is unmistakeable. They have the true flatulent pedantry-the real priggishness of the playhouse monarch. Mr. Cliarles Kean thus identifies himself with the Established Church :-

" "This play is supposed to have been written in 1601, 
fifty-five years after the death of the monarch, a portion of whose life is therein delineated. The five acts occupy twelve years of a busy and most important reign (commencing in 1521, and ending with the christening of the infant Elizabeth in 1533), and include those leading incidents, which were the human means of establishing the STANDARD religion of our country.'

"What does the man mean by the 'standard religion?' Would he, even from amidst his stage carmine, pay a compliment to the Archbishop of Canterbury? Would he, with his hare's foot pat the Established Church on the cheek, as the only standard faith, all sects of dissent being no better than so many pocket-pieces? We fear the manager has had so much to do with stage angels-hanging them to invisible wires for 'effect' - that he believes himself the highest Church authority. Certainly, be never lets the chance of a stage angel escape him. He says-

" "The "Vision' in the chamber of the dying Katharine, at Kimbolton castle, replaces the introduced song of Patience, and the comparatively recent air of Handel, which change, I trust, will be considered more appropriate, as bearing out the queen's description of her dream, and preserving the original idea of Shakespeare.'

"Cpon this literal principle we might have the fanous 'Queen Mab' speech of Mercutio illustrated by a moving panorama. Mr. Kean would make a great hit with the 'tythe-pig ;' and, perhaps, kindly explain in his play-bill the origin of tythes from the original Hebrew. ....

"Mrs. Charles Kean was enthusiastically, nay, affectionately, welcomed on her return to the stage. We hope she may be long spared to grace it. The manager himself thus speaks of the return of Katharine:-

"I cannot conclude this notice without an allusion to Mrs. Charles Kean's return to the stage, after a long secession by severe illness. It is only thus that I can record my appreciation of the compliment she has receired in the voluntary 
proposal of the ladies of the company, not representing characters in the play, to appear as her 'ladies in waiting.' Such an offer is the more valuable, as it combines a graceful expression of personal esteem, with a zealous desire to uphold the interest of the theatre.'

"Very good; but we protest against this cireumstance being adopted as a precedent. We protest against any further appearance of Mr. Charles Kean himself after an illness-for even managers who write on our 'standard religion' are mortal-attended by the Voluntary Principle. We hold up our hands against the probability of a Sardanapalus, with a volunteer guard of Assyrians in the persons of Brown, Jones, and Robinson, to be further multiplied by Robinson, Brown, and Jones.

"We have, for the present, confined ourselves to a notice of the principle of re-production of Shakespeare by means of the painter, the gilder, and the upholsterer. Now, we think there ought to be something higher in the development of the drama, than the art of the painter, and the handiwork of mechanics. As the scenery and furniture hare been made of the first importance, by Charles Kean, he can scarcely complain if they receive the first attention. For upon the high-pressure, doublegilt principle of furnishing, rather than acting plays, it is not impossible that a three-legged 'medieral' stool may be reasonably considered, even before a Cardinal, and that c'ardinal, a Wolsey."

\section{"June 10th, 15.55.}

“TuE 'Princess's' Galleny.-We have receired several letters in condemnation of Mr. Kean's trespass upon the front rows of the gallery for the questionable accommodation of the benighted individuals, doomed by their weakness to pay a box price for a gallery clevation. This is a large tax for the sight of a theatrical furniture warehouse; but if a monomania will pay it, we have nothing to say against the insanity. As to wrong committed upon the gallery audience, they have the best remedy in their own hands-they can kccp away. They 
can see 'Henry VIII.' much better acted at the Standard for a fourth of the sum required of them at the furniture depot at the Princess's. Therefore, it is their own fault, and their own gross extravagance, if they pay a shilling to hear a Wolsey gargle Shakespeare; when, on the other hand, they may hear delightful music admirably sung at Drury Lane for the small charge of sixpence.-One correspondent 'Justice' (who gives his name and address) avows that Mr. Kean did not say 'people of the gallery;' but 'gentlemen of the gallery.' For the letter that appeared in our last we alike had the naine and address of the writer. We are, however, bound to give the denial of "Justice."

\section{"Jully Sth, 1855 .}

"Public Anusements. - The severity of the summer appears to have its effect upon the theatres. . ... Mr. Charles Kean's furniture warehouse in Oxford-street feels the cffect of the hot weatiner, the upholstery of 'Henry VIII.' becoming somewhat neglected. Nevertheless, with a consummate prigoishness worthy of the Barnum of tragedy, the manager steadily puffs his conjugal excellence, continuing to inform an enraptured public of his happiness ' to announce that on this [the hundredth] occasion, Mrs. C. Kean, whose performances have been suspended for nearly a year and a-half by severe and $m^{\prime r}$ tracted illness, will make her re-appearance.' Most happy were the public to welcome the return of Mrs. C. Kean to the stage, and most heartily do we hope that she may long be spared to it ; for what would become of us if given up to the cruel tragedy of Mr. C. Kean, unnitigated by the graces of his wife?"

\section{"July 22d, 1855.}

"Mr. W. Farren has finally retired from the stage to the domesticity of his hearth; where, we hope, he may long be the especial care of the fireside gods. Mr. Farren has been nearly half-a-century an actor. He won his first successes in Dublin,-and, whilst a very young man, secured for 
himself a sudden and lasting popularity at Covent Garden; and that, too, at a time when the stage boasted of very many first-rate artists. Now, the stage las two, or three, or fuur, or -(we fear we cannot go on)-really fine actors. As an art, acting in England is dying out; now painted out by the scene-painter,-and now smothered under the velvet cushions of the upholsterer. When Farren came out at Covent Garden, Ednund Kean was a mighty Shakespearean presence at Drury Lane. Farren bids adieu at the Ilaymarket, and Upholsterer Kean furnishes Shakespeare with chairs and tables at the Princess's! A Kean of flesh and blood and a Kean of woodFrench polished."

\section{"August 31st, 1556.}

" 'P'izarro' Will be given on the reopening of the Princess's to-morrow; Mr. C. $K$ an in his farewell address of the $22 \mathrm{~d}$ inst. promising that Sheridan's play 'should be revived with the same attention to details which has accompanied the whole of the previous series of historical illustrations.' We have no doubt that the spectacle will be very fine. 'Pizarro' is just the sort of play that may be fairly converted into a clothes-peg. The rant and fustian of Sheridan, who worked upon the old German translation as a mere thing to draw money, entrapped George III. into passing applause of the brilliant whig. Mr. Kean plays liolla: his intellectual and histrionic qualifications are exactly up to the part. As for the 'Winter's Tale,' we never saw so much heautiful scenery with so much dreary acting. It was Shakespeare not illustrated, but painted out. The whole thing was a moving panorama. We confess that we prefer a moving play."

\section{"Oct. 19th, 15.56.}

" 'A Minstumer Nigut's Dnean,' as painted at the P'rincess's. and exhibited for the first time on W'edneslay, must remain for notice until next week. As the pictorial glories are quite as bright as rainbows, but not so evanescent, they can wait." 
"Oct. 26th, 1855.

"Eletation of tife Drama.-In the Morning Herald there was a long critieism on 'A Midsummer Night's Dream,' as usual written 'on the premises ;' in which the retained critic declares that Mr. Kean has 'elevated the national drama.' And so he has. He has hung it on a clothes-peg."

" 'A Minsumer NigitT's Dream.'-It is a great fact, which nobody will therefore believe, that complaining, in time, becomes a very tedious business. ... . Therefore, on purely selfish grounds, we regret that there is no marked improvement in the series of dramas undergoing 'illustration' at the Princess's theatre; and we are, in consequence, doomed to the dullest reiteration.

"In the first place, we have to see what all this illustration comes to. No one can reasonably object to having an author's scenes painted as carefully and as historically as possible. That is of great service, and is, in fact, History as some of our greatest writers have desired to have it. But Mr. Kean says now, as he has befure said, that he has not adopted the real era of the play, because it was a less civilised era than another, which he has therefore substituted. Now, if this principle be once admitted as good law, where is it to end? Suppose an English play. Suppose Mr. Kean revives 'King John,' 'with that attention to historical detail which has hitherto,' ctc. He will find, in all probability, very meagre information and still more meagre civilisation to work upon. A dreadful dilemma, from which the escape is obvious. It is not Mr. Kean's fault that the early centuries were brutal and ignorant, and why should he be plagued with them when the nineteenth century is ready cut and dried to hand? King Joln, there- fore, instead of making his mark on Magna Charta, will at all events take six easy lessons of Mr. Smart, and the deed will be deposited with the barons' solicitors. 'The thunder of our cannon,' that trifling poetic licenee, will be fully supported, and correct models of the last ordnance failures will be placed 
before the public as specimens of five hundred years ago. Thus is History taught at the Princess's. But why does the manager sometimes 'deviate into sense?' Why was not the trial of Queen Katharine modelled on that of Queen Caroline, of which event we have far more copious accounts? Such questions inight be endlessly repeated, if once the original position be respected as sound policy.......

"Any concluding observations would sound like a summing up. It may be done in one word. All the requisites for at good representation of a drama are known and undeniable : Are they here? Certainly not. There is only one of the elements, but that is surpassingly beautifnl. But that is no excuse, and we instinetively assume the black cap before making our bow to Mr. Kean."

"Nor: 9th, 1556.

“'Tue 'Drana' at tue Princess's. - At other theatres there is no insuperable obstacle to the restoration of a current dramatic literature; at the Princess's there is such an obstacle. At other theatres what is presented to the public consists at least of drama in some shape, inferior in degree, or eccentric in species, but still, good or bad, resting its main pretensions upon recognised grounds of dramatic interest ; at the Princess's alone an attempt is making, hitherto with a certain anount of success, to substitute something else for the drama; to subordinate the play, whatever may be its merits, new or old, to the spectacle; to make costume, scenery, and mechanism paramount to poetry and action; to corrupt the taste of the spectators by satiating them with gauds; and ultimately to weaken their sense of the moral dignity and beauty of the performance by associating it with extraneous exhibitions which dazzle the eyes and lull the judgment. . . . . . .

"Now, in other theatres, the play, marred, or mutilated, or travestied, is still 'the thing ;' but it is not the thing at the Princess's. . . . It would be curious enough to speculate upon the number of new plays of the highest class which 
might have been procured, and which night thus have given an important stimulus to production in that branch of literature, for the $5,000 l$. said to have been expended upon the scenery and properties of a single revival at the Princess's. It is no doubt to be lamented that the system is inimical to original production; but even the total suppression of authorship is preferable to a breed of spurious pieces in which the whole function of the dramatist should be to act as showman to the tailors and scene-painters.-Literary Gazetie.[And for this the Morning Herald, by means of the hireling critic of the manager, asks that Mr. Kean should be 'knighted!']"

\section{"March 15th, 1857.}

“' 'Richard the Second' has been produced at the Princess's with all the elaborate pomp and splendour with which Mr. Charles Kean ordinarily furnishes the text of Shakespeare. Perhaps there is no play that can suffer less at the hands of the scene-painter and decorator than 'Richard the Second;' inasmuch as the play is comparatively deficient of great acting situations. Indeed, it is rather a stage-chronicle than a drama, and as such is susceptible of decoration. It is otherwise with 'Macbeth,' for instance. In that play, 'the air-drawn dagger' as seen by the actor ought to interest us more than the goblets of the banquet-scene, however massive and however real. We shall in our next speak at length of this last triumph of the Princess's artists and decorators!"

THE END. 

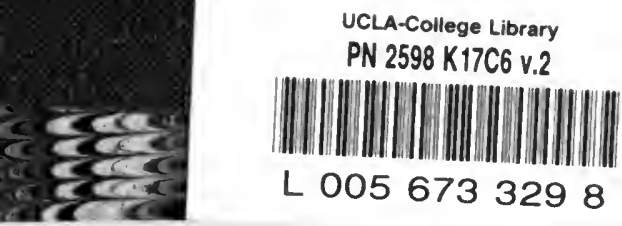

Colleg Lib. PN

2598

K17C6

$\mathrm{v} .2$

C SOUTHEAN REGIONAL LIBAARY FACIIT

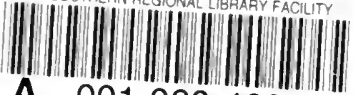

A 0010604601

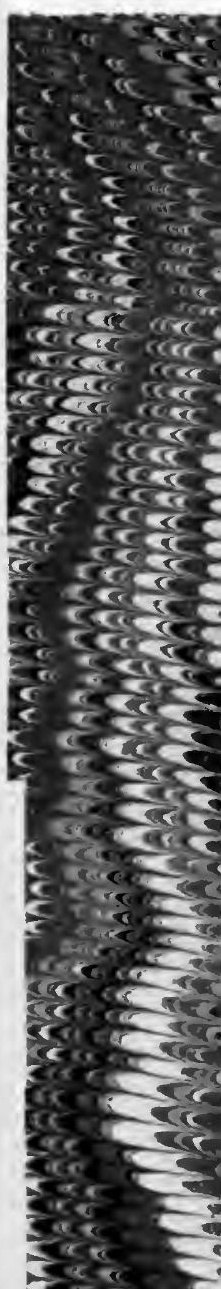




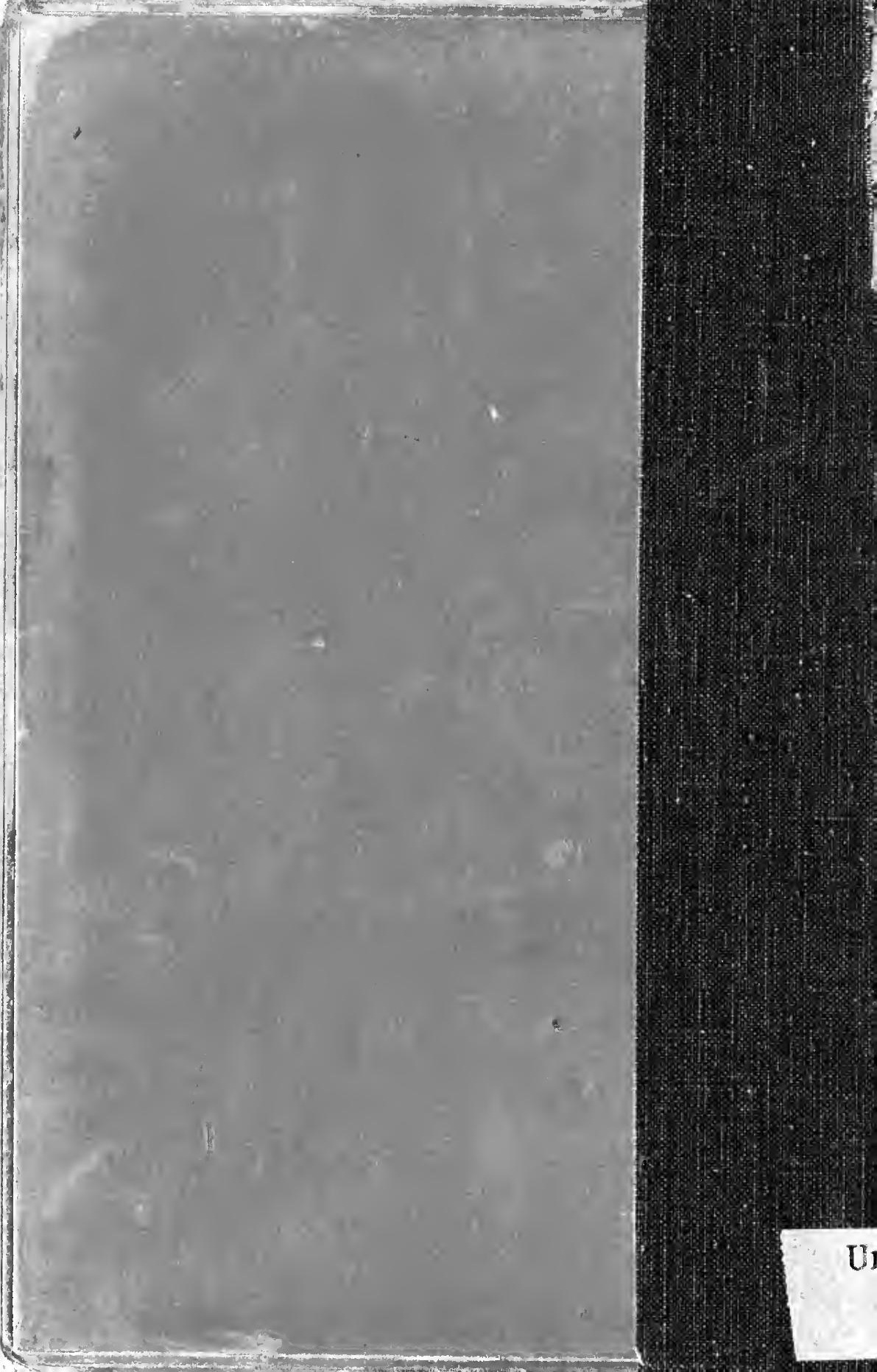

